Universidade de São Paulo Instituto de Arquitetura e Urbanismo

\title{
PRODUÇÃO EM ESCALA DA HABITAÇÃO E RACIONALIŻAÇÃOO DE CANTEIROS DE OBRAS
}

Jaqueline De Pieri Quaglio

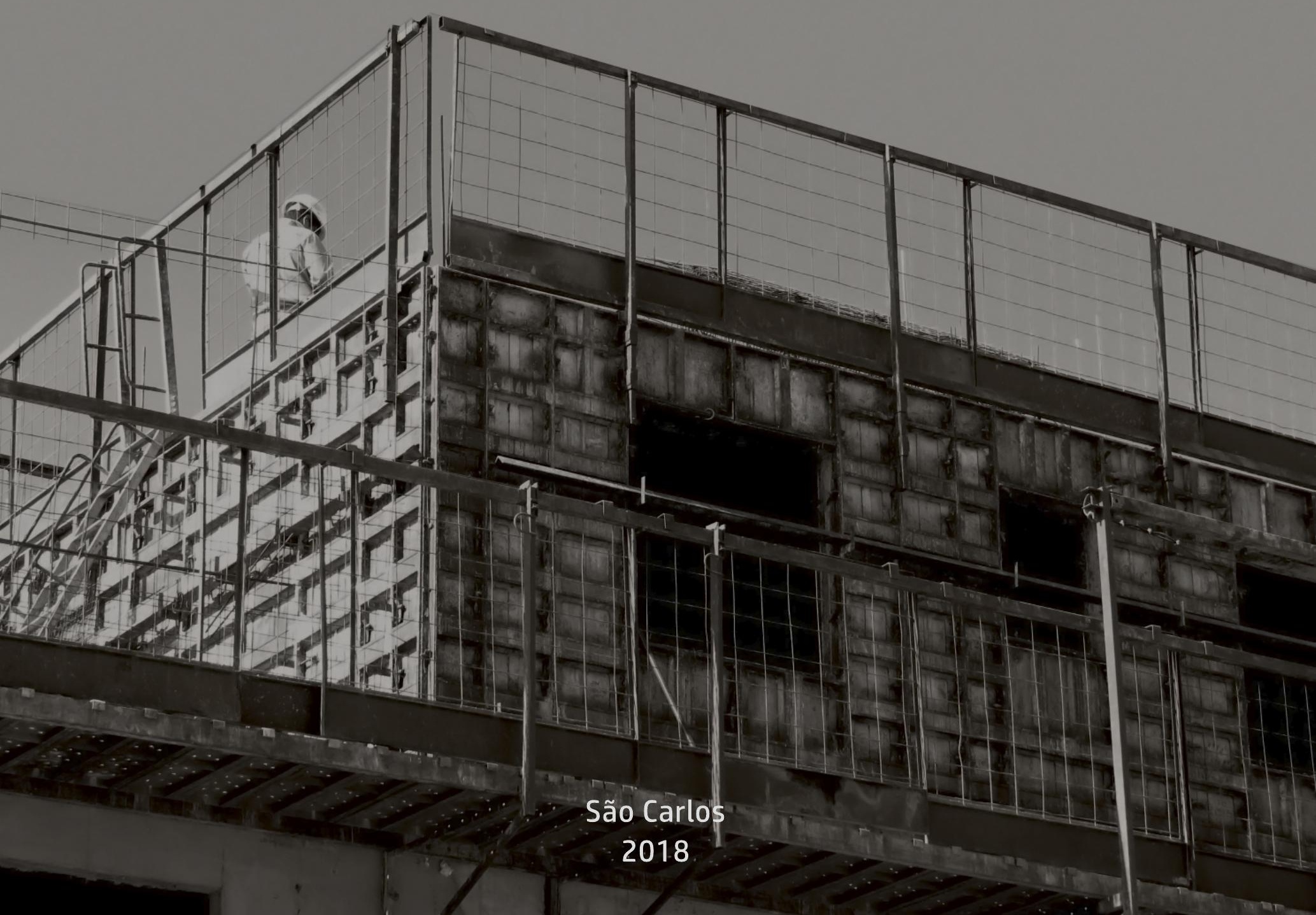





\author{
UNIVERSIDADE DE SÃO PAULO \\ INSTITUTO DE ARQUITETURA E URBANISMO
}

\title{
PRODUÇÃO EM ESCALA DA HABITAÇÃO E RACIONALIZAÇÃO DE CANTEIROS DE OBRAS
}

Jaqueline De Pieri Quaglio

Dissertação apresentada ao Instituto de Arquitetura e Urbanismo da Universidade de São Paulo para obtenção do título de Mestre em Arquitetura e Urbanismo

Área de Concentração: Arquitetura, Urbanismo e Tecnologia

Orientadora: Profa. Dra. Lúcia Zanin Shimbo 
Autorizo a reprodução e divulgação total ou parcial desta Dissertação de Mestrado, por qualquer meio convencional ou eletrônico, para fins de estudo e pesquisa, desde que citada a fonte.

Email: jaquequaglio@gmail.com

Exemplar revisado e alterado em relação à versão original, sob responsabilidade do autor e anuência da orientadora. 0 original se encontra na sede do programa.

Ficha catalográfica elaborada pela Biblioteca do Instituto de Arquitetura e Urbanismo com os dados fornecidos pela autora

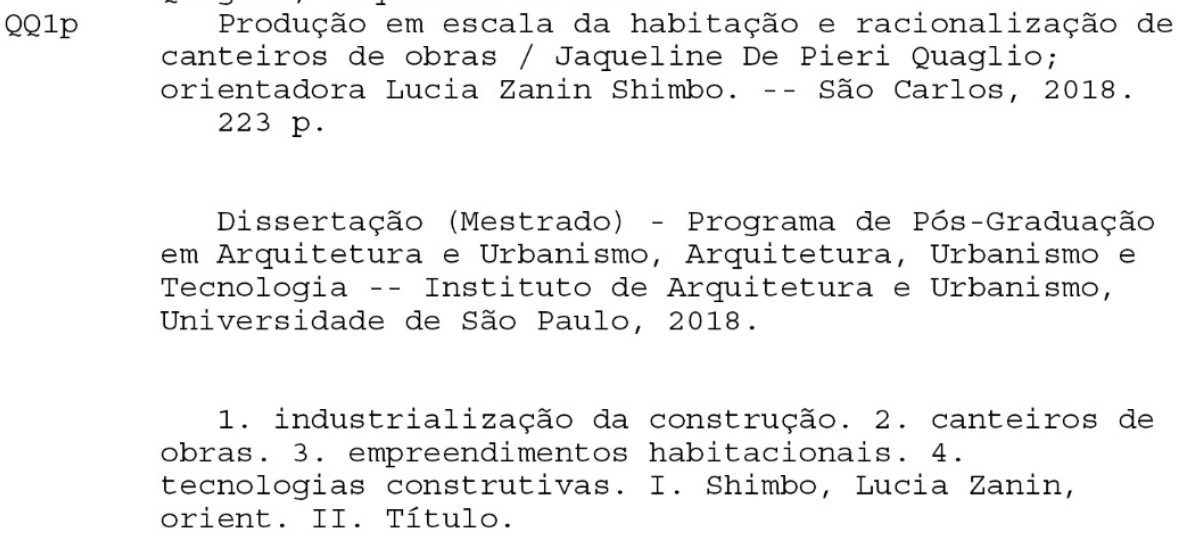




\section{FOLHA DE JULGAMENTO}

Candidato(a): Jaqueline de Pieri Quaglio

Título da dissertação: "Produção em escala da habitação e racionalização de canteiros de obras".

Data da defesa: 08/06/2018

Orientador: Profa. Dra. Lucia Zanin Shimbo

Comissão Julgadora:

$$
\text { hui Zanni Shmi }
$$

Profa. Dra. Lucia Zanin Shimbo (IAU/USP)

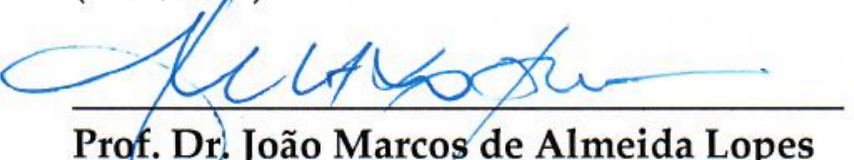

(IAUTUSP)

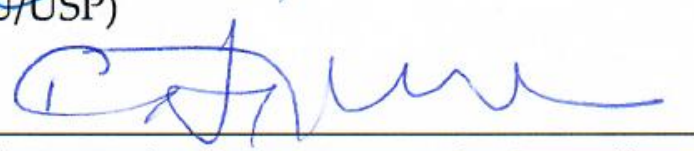

Prof. Dr. Caio Santo Amore de Carvalho (FAU/USP)

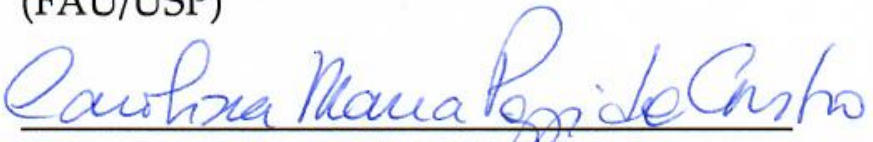

Profa. Dra. Carolina Maria Pozzi de Castro (UFABC)
Resultado:

Não votante
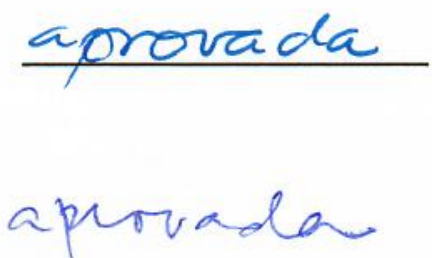

aprovada

Coordenadora e Presidente da Comissão de Pós-Graduação do Programa de PósGraduação em Arquitetura e Urbanismo: Prof. Dr. Tomás Antonio Moreira. 


Para Gláucia e Osvaldo. 



\section{AGRADECIMENTOS}

Após um caminho de questionamentos e incertezas, agradeço imensamente à professora Lúcia Shimbo, orientadora deste mestrado, pelo apoio e compreensão durante esses anos de trabalho.

Aos professores João Marcos, Caio Santo Amore e Carolina Pozzi pelas valiosas contribuições dadas durante a defesa deste mestrado.

Aos professores responsáveis pelas disciplinas que tanto acrescentaram a este trabalho de pesquisa e também à minha formação pessoal: João Marcos, Cibele Rizek, Ruy Sardinha, Renato Anelli, Eulália Negrelos, Tomás Moreira, Kelen Dornelles, Aline Corato. Em especial, agradeço à professora Akemi Ino, pela proximidade e pelas oportunidades que generosamente me concedeu.

A todos os engenheiros e trabalhadores dos canteiros de obras que muito colaboraram para os resultados aqui apresentados.

Às pessoas que de alguma maneira participaram desta trajetória - agradeço pelo apoio, pelos questionamentos, pelo carinho e pela paciência.

À Maiara e Rafael, por simplesmente estarem presentes. Às minhas queridas, Ana Laura, Caroline, Eleonora, Gabriela, Marina e Natalia, pela amizade tão rica, pelos conselhos e por tantos momentos incomparáveis. À Ana e Mel, por me ensinarem tantas maneiras de olhar o mundo. E à Lindy, essencial no final dessa caminhada.

À minha família, sempre tão presente e necessária. Ao meu irmão, Filipe, por dividir comigo um espaço nesse mundo. Aos meus pais, pelo esforço de toda uma vida e pelo apoio incondicional. 

Num cenário marcado pela intensificação da competitividade, há uma orientação generalizada para a busca de maior eficiência, através do aumento da produtividade, da redução de prazos de execução e de custos de produção. As inovações introduzidas no processo de trabalho - sejam tecnológicas, sejam organizacionais - respondem, de um modo geral, a estes requisitos. 

QUAGLIO, JAQUELINE DE PIERI. Produção em escala da habitação e racionalização de canteiros de obras. 2018. Dissertação (Mestrado) - Instituto de Arquitetura e Urbanismo, Universidade de São Paulo, São Carlos, 2018.

A construção civil frequentemente foi objeto de diversos estudos devido à sua importância no cenário econômico no país. Uma primeira tendência de debate compreendeu o setor da construção sob a chave do atraso, uma vez que suas atividades eram marcadas por condições precárias de trabalho, baixa organização produtiva, altos custos e desperdícios. A industrialização plena da construção representaria, de acordo com esses estudos, o desenvolvimento tecnológico do setor. Uma segunda tendência de debate, mais recente, identificou que, apesar do setor da construção carregar um histórico de precariedades, houve considerável avanço em relação à racionalização da produção nas últimas décadas.

A partir dos anos 2000, no Brasil, empreendimentos habitacionais de grande envergadura destinados à baixa renda foram promovidos por construtoras e incorporadoras através de recursos públicos. A questão que se coloca é como se viabilizou tal produção massiva de moradias, em um curto período de tempo, no âmbito dos canteiros de obras? 0 objetivo principal desta pesquisa, portanto, é identificar e analisar diferentes tendências de industrialização nos canteiros de obras da produção em larga escala da habitação.

A partir de três estratégias metodológicas de pesquisa - bibliográfica, de campo e documental -, analisamos a produção em alguns canteiros de obras de duas empresas construtoras. Identificamos, na produção dos empreendimentos habitacionais de larga escala, a implementação de estratégias de organização, de gestão e de controle que permitiram ganhos expressivos de produtividade. Não se tratava, nos casos analisados, da industrialização plena da construção, mas sim de um processo intenso de racionalização da produção.

Palavras-chave: industrialização da construção; canteiros de obras; empreendimentos habitacionais; tecnologias construtivas. 
QUAGLIO, JAQUELINE DE PIERI. Scale production of housing and racionalization in construction sites. 2018. Dissertação (Mestrado) - Instituto de Arquitetura e Urbanismo, Universidade de São Paulo, São Carlos, 2018.

Civil construction has often been a subject of several studies due to its importance for the economic scenario in the country. At first, the construction sector was understood as a synonymous of economic backwardness, since its activities were grounded by precarious working conditions, low productive organization, high costs and wasting. According to those studies, only the fully industrialization of the construction would represent the technological development of the sector. A second discussion tendency has identified that despite the insecurity historic of the construction industry, there has been considerable progress related to the production rationalization in the recent decades.

From the 2000's in Brazil, large-scale housing projects destined for low-incomes were promoted by construction companies and developers through public resources. At this point, the question that arises is how did such a massive production of housing become possible in a short period of time in the scope of building sites? Therefore, this research's main goal is to identify and analyze the industrialization trends in the building sites of the large-scale housing production.

Based on three methodological research strategie - bibliographical, field and documentary - this research analyzed the building sites of two construction companies. It was identified at the production of large-scale housing developments, the implementation of organizational, management and control strategies which allowed significant gains on productivity. In the analyzed cases, it was not about the fully industrialization of construction, but an intense process of production rationalization.

Keywords: construction industrialization; building sites; housing developments; constructive technologies. 
Imagem 1-Localização do empreendimento ALV_APTO em São Carlos.................................................2

Imagem 2 - Localização do empreendimento PC_APTO_1 em Araraquara. .............................................28

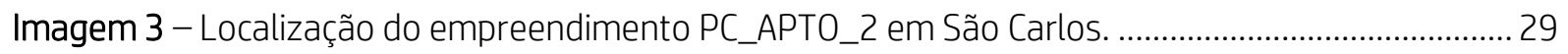

Imagem 4 - Localização do empreendimento PC_CASA_1 em São Carlos................................................ 30

Imagem 5 - Localização do empreendimento PC_CASA_2 em Araraquara................................................ 31

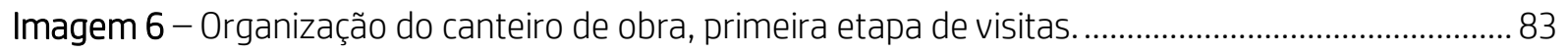

Imagem 7 - Organização do canteiro de obra, segunda etapa de visitas.................................................. 84

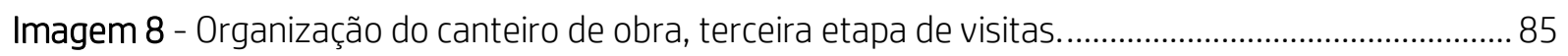

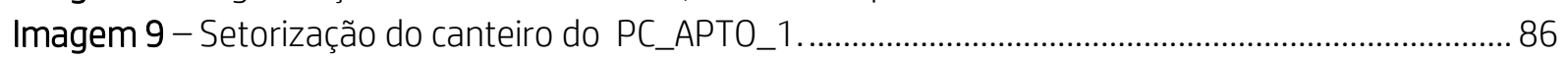

Imagem 10 - Setorização do canteiro do PC_CASA_1 ........................................................................ 87

Imagem 11 - Organização das instalações de apoio do canteiro do PC_CASA_1 ..................................... 87

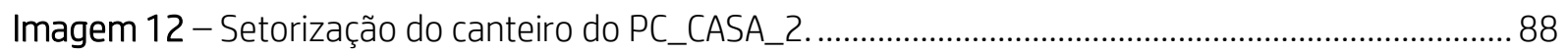

Imagem 13 - Organização das instalações de apoio do canteiro do PC_CASA_2 ..................................... 88

Imagem 14 - Almoxarifado do PC_APTO_1 alojado em instalação permanente.......................................90

Imagem 15 - Escritório do PC_APTO_1 alojado em instalação permanente............................................90

Imagem 16 - Alojamento e refeitório de funcionários do empreendimento PC_CASA_1 1....................... 91

Imagem 17 - Refeitório do empreendimento PC_CASA_2 ………….................................................... 92

Imagem 18 - Cozinha do empreendimento PC_CASA_2 ...................................................................... 92

Imagem 19 - Escritório do empreendimento PC_CASA_2 ………........................................................ 92

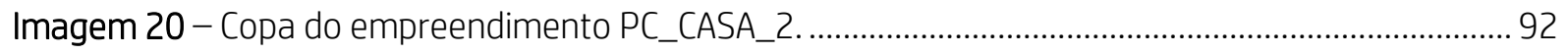

Imagem 21 - Almoxarifado e Escritório do empreendimento ALV_APTO..................................................93

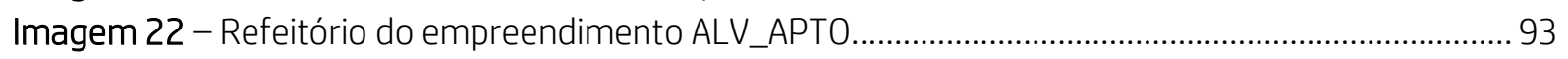

Imagem 23 - Laboratório de concreto do empreendimento PC_CASA_1 ..................................................93

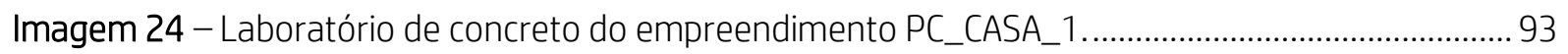

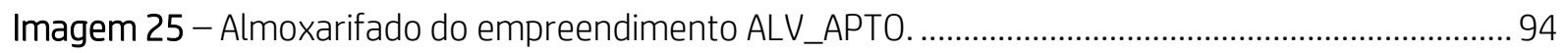

Imagem 26 - Almoxarifado do empreendimento PC_CASA_2 . ...............................................................94

Imagem 27 - Canteiro do ALV_APTO, sem a infra 360…....................................................................... 96

Imagem 28 - Canteiro do PC_APTO_1, com a infra 360….................................................................96

Imagem 29 - Canteiro do PC_CASA_1, já com a infraestrutura executada..............................................97

Imagem 30 - Canteiro do PC_CASA_2, sem a infraestrutura executada..................................................97

Imagem 31 - Armazenagem de materiais no ALV_APTO ............................................................................ 99

Imagem 32 - Armazenagem de materiais no PC_APTO_1 ...................................................................100

Imagem 33 - Armazenagem de materiais no PC_APTO_2. .................................................................. 100

Imagem 34 - Armazenagem de blocos de concreto no ALV_APTO. .......................................................101

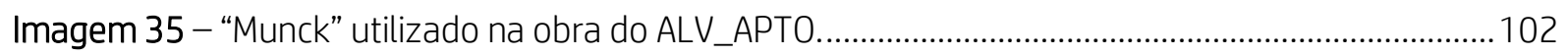

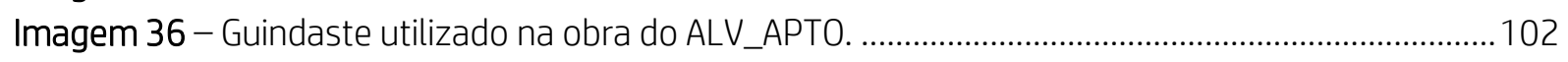

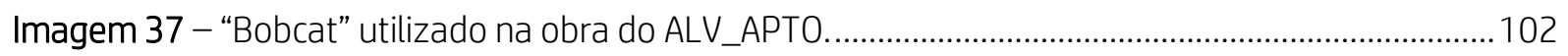

Imagem 38 - "Skytrack" utilizada na obra do ALV_APTO.........................................................................102

Imagem 39 - Tabela de traços utilizada no ALV_APTO. .........................................................................106

Imagem 40 - Base de preparação de blocos de alvenaria e armaduras do ALV_APTO............................110

Imagem 41 - Base de preparação dos kits hidráulicos do PC_CASA_1 ................................................110

Imagem 42 - Base de preparação de concreto e argamassa do ALV_APTO.............................................110 


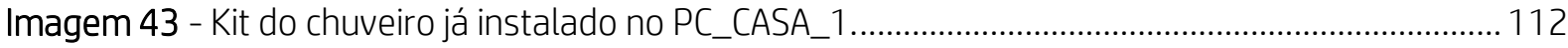

Imagem 44 - Kit do chuveiro e ramais de esgoto já instalados no PC_APTO_1 . ..................................112

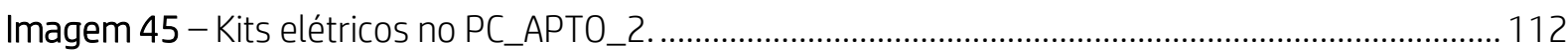

Imagem 46 - Detalhe dos kits elétricos já presos à armadura no PC_CASA_2 ........................................112

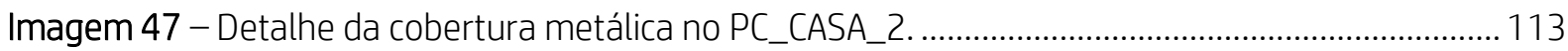

Imagem 48 - Detalhe da cobertura metálica no PC_CASA_1 . ...............................................................113

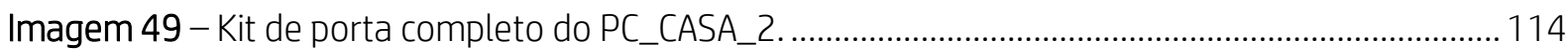

Imagem 50 - Kit de porta e janela completos do PC_CASA_1 .............................................................. 114

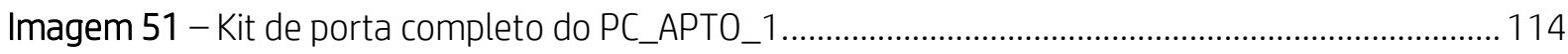

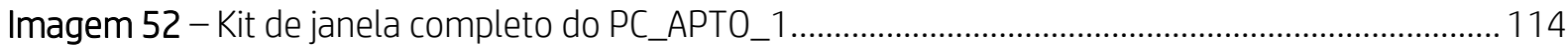

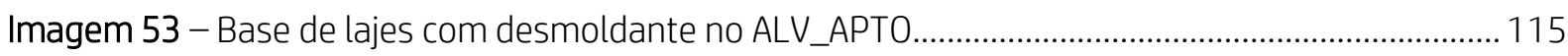

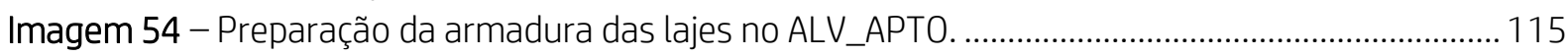

Imagem 55 - Preparação da armadura e dos conduítes das lajes e no ALV_APTO................................116

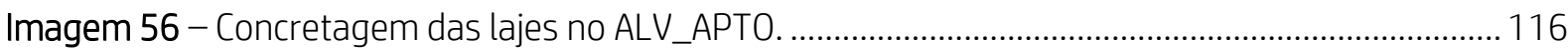

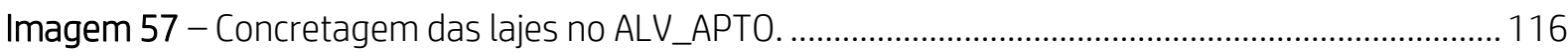

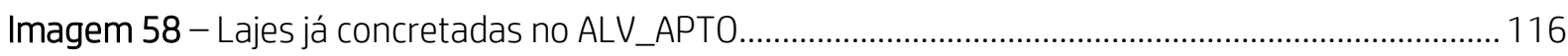

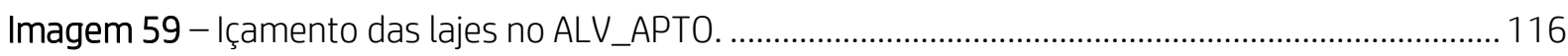

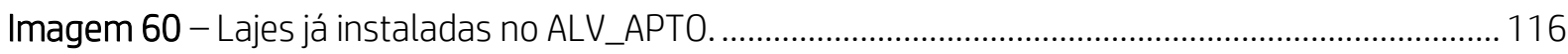

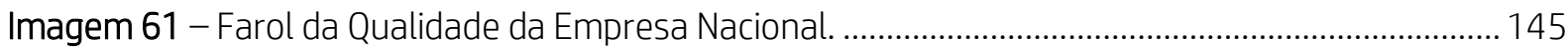

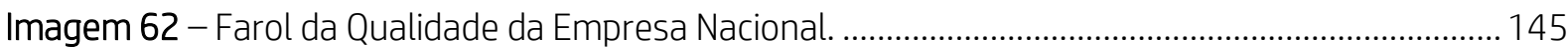

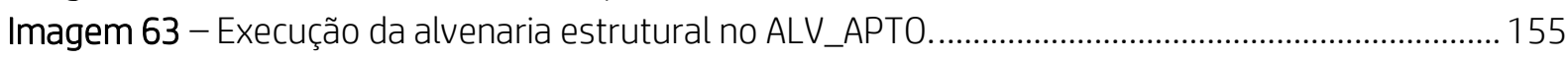

Imagem 64 - Execução da alvenaria estrutural no ALV_APTO ………................................................155

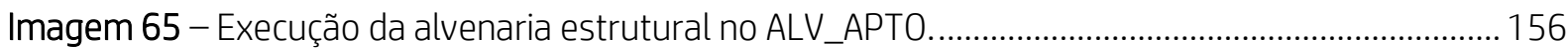

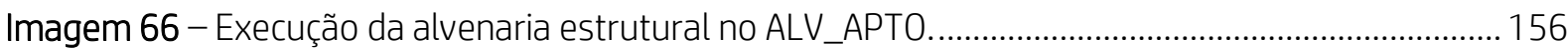

Imagem 67 - Preparação dos corpos de prova no PC_CASA_2 - Empresa Regional.............................. 161

Imagem 68 - Corpos de prova PC_CASA_1 - Empresa Regional. ........................................................... 161

Imagem 69 - Preparação dos corpos de prova no PC_APTO_1 - Empresa Nacional...............................161

Imagem 70 - Preparação teste de cone no PC_APTO_1 - Empresa Nacional. ..........................................161

Imagem 71 - Montagem das armaduras e instalações sobre gabarito no PC_APTO_1 .........................165

Imagem 72 - Içamento das armaduras das lajes no PC_APTO_1 ........................................................165

Imagem 73 - Posicionamento das armaduras no respectivo pavimento no PC_APTO_1 .....................166

Imagem 74 - Montagem das armaduras e instalações no PC_CASA_1 ................................................. 166

Imagem 75 - Montagem das armaduras e instalações no PC_CASA_2 . ................................................. 166

Imagem 76 - Montagem das fôrmas nos blocos de apartamentos no PC_APTO_1 .............................. 168

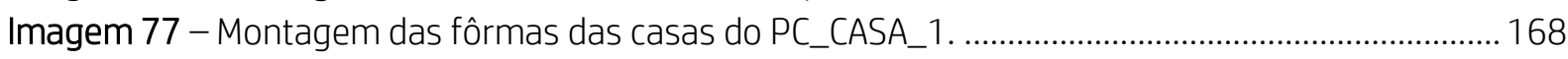

Imagem 78 - Montagem das fôrmas das casas do PC_CASA_1 . ........................................................168

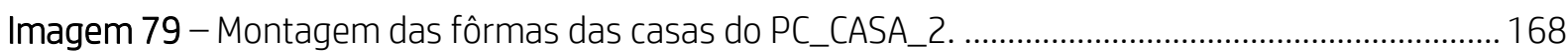

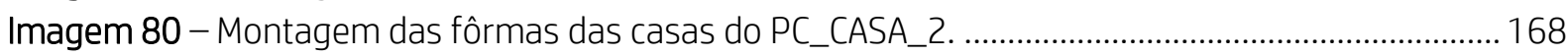

Imagem 81 - Montagem das fôrmas das casas do PC_CASA_2 . .......................................................... 169

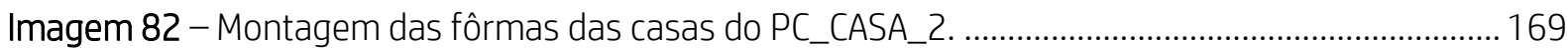

Imagem 83 - Montagem das fôrmas das casas do PC_CASA_1 .........................................................169

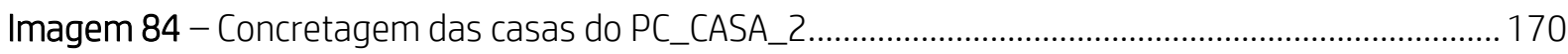

Imagem 85 - Concretagem dos apartamentos do PC_APTO_2 …………………............................... 170

Imagem 86 - Detalhe do 'jacaré' da escada no PC_APTO_1 ................................................................ 173

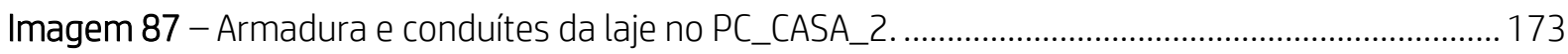

Imagem 88 - Defeito gerado no momento da desenforma no PC_CASA_2 ........................................... 174

Imagem 89 - Defeito gerado no momento da desenforma no PC_CASA_2 ........................................... 174 


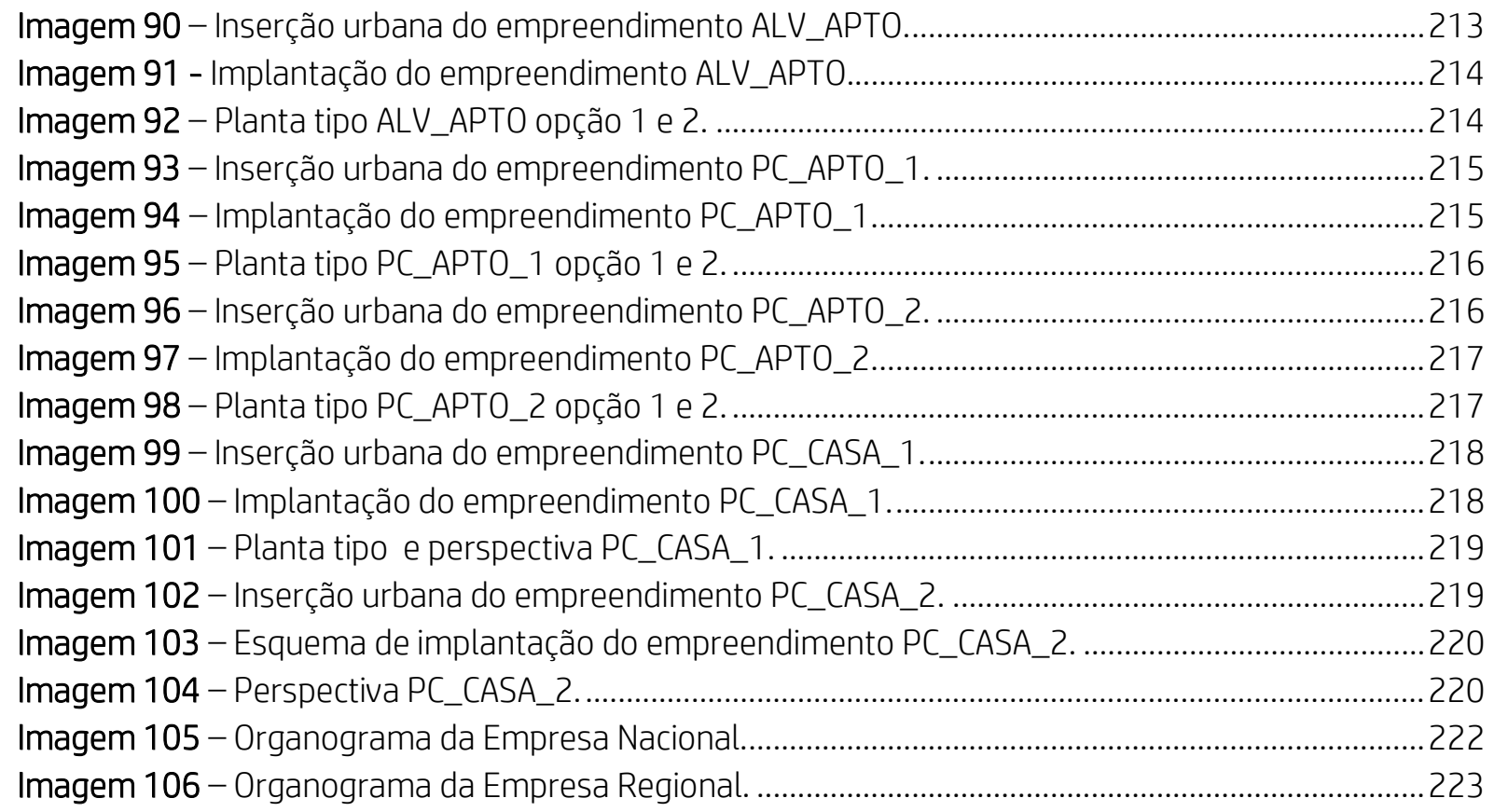

\section{LISTA DE GRÁFICOS}

Gráfico 1 - VGV versus Vendas Contratadas da Empresa Nacional (2004-2017), em R\$ milhões......... 35

Gráfico 2 - Cadeia produtiva da construção por participação (\%) no PIB total da cadeia (2015) ............ 46

Gráfico 3 - PIB Brasil x PIB Construção civil (\%) - 2004 a 2016 ............................................................... 47

Gráfico 4 - Incorporações, obras e/ou serviços dentro do setor da construção - 2014 e 2015 .............. 48

Gráfico 5 - Emprego formal na construção civil (em milhões) 2007 a 2015 ............................................. 49

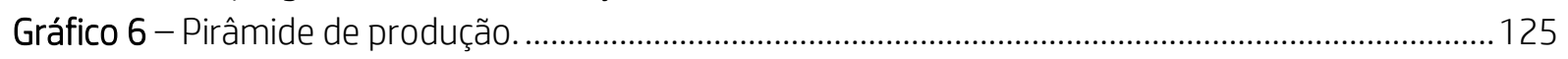

Gráfico 7 - Controle técnico do trabalho na Empresa Nacional (\%)........................................................126

Gráfico 8 - Evolução no número de empregados nas obras da Empresa Nacional. ................................127

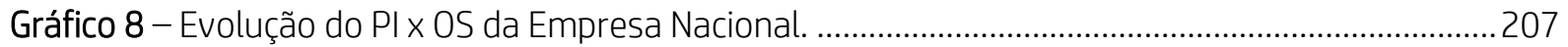

Gráfico 9 - Evolução dos métodos construtivos da Empresa Nacional (unidades).................................208

\section{LISTA DE QUADROS}

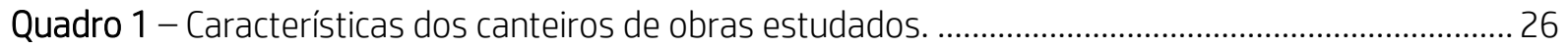

Quadro 2 - VGV, de Vendas Contratadas e lucro líquido da Empresa Nacional (2004-2016). ............... 34

Quadro 4 - Procedimentos de Execução e Serviços (PES).......................................................................105

Quadro 5 - Empresas prestadoras de serviços de construção do ALV_APTO. ..........................................135

Quadro 6 - Empresas e serviços subempreitados - PC_CASA_1 ......................................................136

Quadro 7 - Texto integral apresentado pela Empresa Nacional. ................................................................184

Quadro 8 - Texto integral apresentado pela Empresa Nacional. ............................................................188

Quadro 9 - Texto integral apresentado pela Empresa Nacional. .........................................................191

Quadro 10 - Resumo das propostas de desafios da Empresa Nacional e suas especificidades...........195 


\section{LISTA DE SIGLAS}

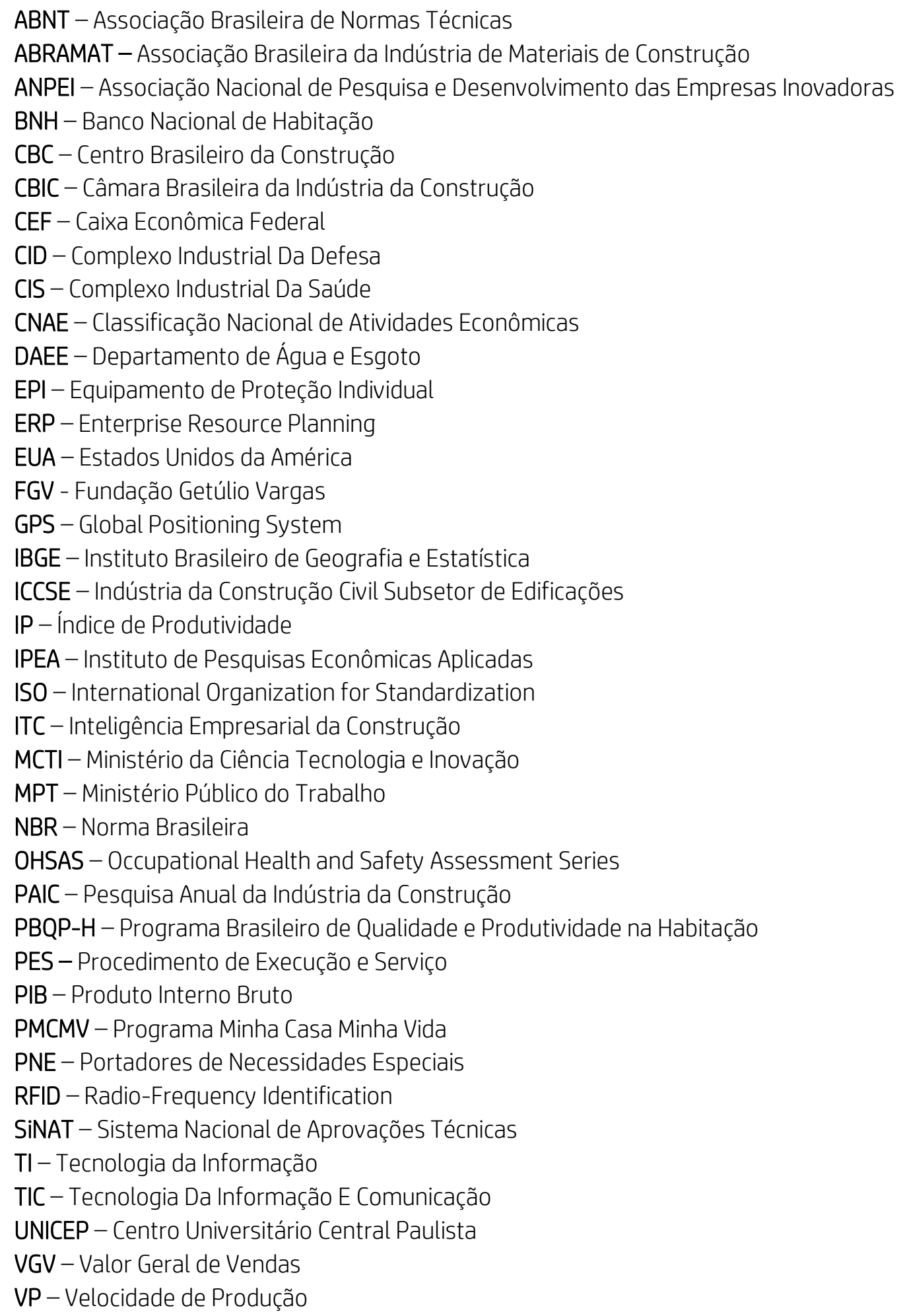





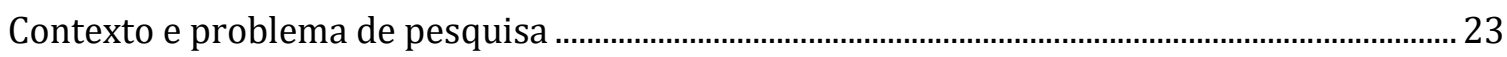

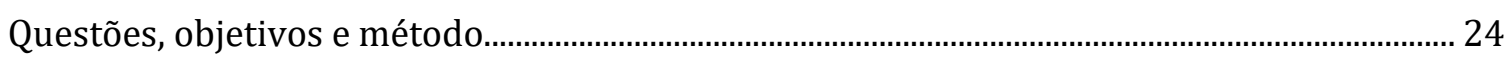

Os resultados obtidos e organização da dissertação ........................................................................ 39

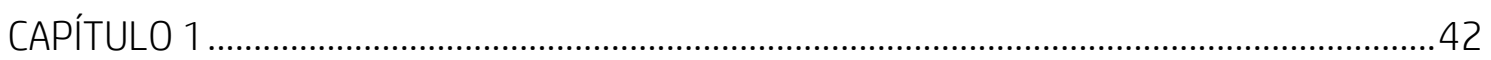

Racionalização e Industrialização na Construção Civil............................................................... 42

1.1. O setor da construção civil nas pesquisas setoriais ……………………………………..... 44

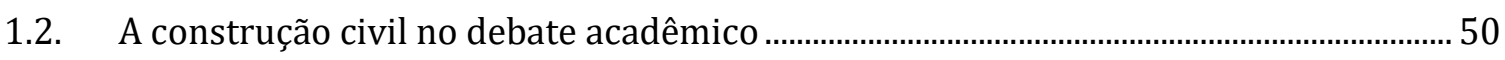

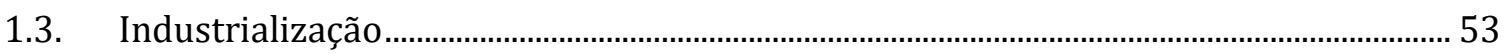

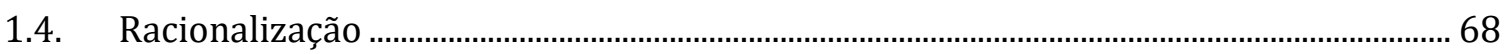

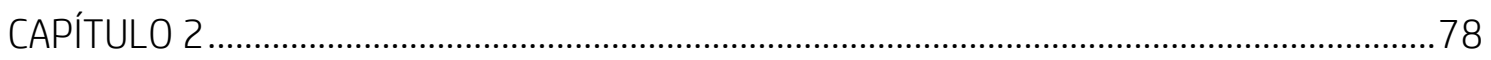

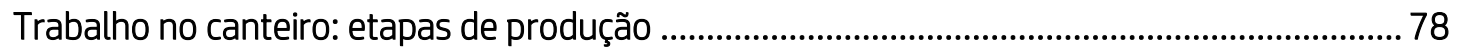

2.1. Planejamento e organização da produção: layout, instalações e armazenagem.......... 80

2.2. Instrumento de prescrição .................................................................................................103

2.3. Preparação, 'kits' prontos e pré-fabricação ………………………………………………...107

2.4. Iniciativas de mecanização ..............................................................................................118

Regulamentação e controle do trabalho.

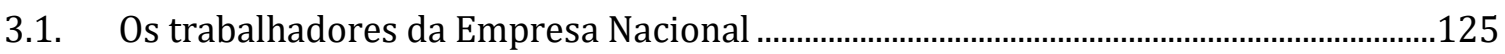

3.2. Os trabalhadores da Empresa Regional ........................................................................130

3.3. A predominância da subempreitada................................................................................131

3.4. A mudança na forma de contratação da Empresa Nacional............................................137

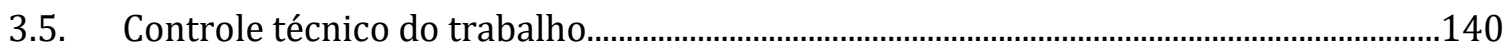

3.6. Os salários e bonificações por produtividade ......................................................................146 
CAPÍTULO 4.

Da alvenaria estrutural às paredes de concreto

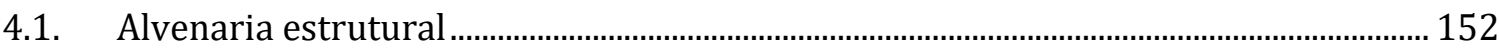

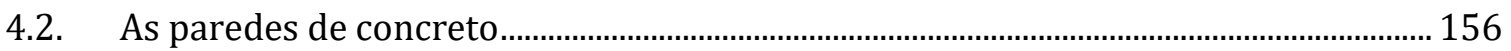

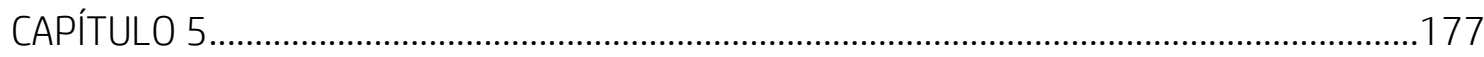

As perspectivas de inovação da Empresa Nacional............................................................. 177

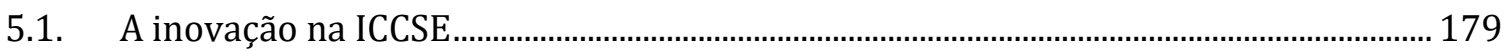

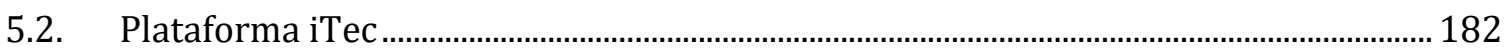

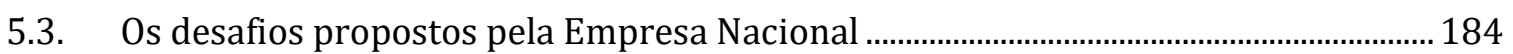

5.4. A racionalização e a padronização como perspectivas da Empresa Nacional ............. 195

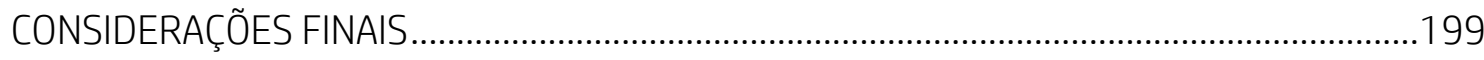

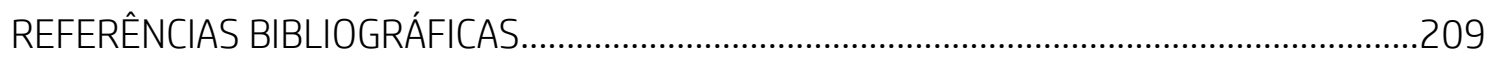

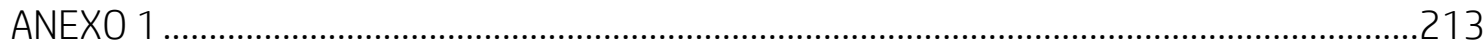

Caracterização dos empreendimentos analisados............................................................213

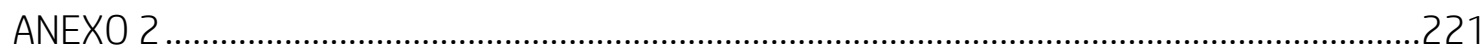

Organogramas das empresas construtoras pesquisadas ...................................................... 221 


\section{INTRODUÇÃO}

Desde os anos 2000 no Brasil, grandes construtoras e incorporadoras promoveram empreendimentos habitacionais de grande envergadura, destinados às famílias de baixa e média renda, a partir de incentivos governamentais. Trata-se de um fenômeno inédito no país, considerando-se o volume de subsídios públicos e o elevado número de moradias produzido em curto prazo $^{1}$. A rápida ampliação da escala demandou processos e estratégias avançadas de produção no canteiro de obras. Diante desse problema, surgiram as questões que motivaram esta pesquisa: Como se viabilizou a ampliação da escala de produção da habitação? Foram adotadas iniciativas de industrialização pelas empresas construtoras nos canteiros de obras?

Após o desenvolvimento da pesquisa empírica e também do aprofundamento teórico sobre o setor da construção civil, identificamos a implementação de diversas iniciativas de racionalização da produção dos grandes empreendimentos de moradia, que não correspondiam exatamente aos preceitos clássicos da industrialização plena da construção. Tratava-se, sobretudo, de estratégias de gestão e controle que visavam racionalizar o processo de trabalho nos canteiros de obras e aumentar sua produtividade. O objetivo desta dissertação é, portanto, analisar algumas de tais estratégias à luz do debate sobre racionalização e industrialização da construção civil no Brasil.

\footnotetext{
1 Até os anos 2000, a maior produção habitacional no Brasil destinada à baixa renda e financiada pelo estado ocorreu durante o período do BNH. Em 22 anos foram produzidas 4,5 milhões de unidades habitacionais. Por outro lado, em apenas cinco anos, entre 2009 e 2014, foram contratadas 3,5 milhões pelo Programa Minha Casa, Minha Vida (PMCMV). Daí o caráter inédito da larga escala de produção em curtíssimo período de tempo (AMORE; SHIMBO; RUFINO, 2015, p.19).
} 


\section{Contexto e problema de pesquisa}

Nas últimas duas décadas, o setor privado marcou seu maior protagonismo na produção habitacional do país através da consolidação de um mercado voltado ao segmento econômico. Nesse contexto, em 2009 foi lançado o Programa Minha Casa, Minha Vida $(\mathrm{PMCMV})^{2}$ com a proposta de ampliar vertiginosamente a produção de moradias no país. O Programa se colocava também como uma ação combativa à crise financeira global iniciada nos Estados Unidos da América (EUA) no ano anterior ${ }^{3}$. O PMCMV entra, portanto, no cenário brasileiro, como o mais importante programa para a produção de moradias sociais. Desde o vácuo deixado pelo final da produção do Banco Nacional de Habitação (BNH), apenas a autoconstrução habitacional tinha conseguido atingir as famílias de mais baixa renda da população de maneira mais expressiva (BARAVELLI, 2014).

Buscando compreender quais os fatores que possibilitaram tal modelo habitacional, do ponto de vista da produção, nos voltamos aos estudos sobre o setor da construção civil e identificamos neles duas tendências de debate ${ }^{4}$. A primeira, com análises desenvolvidas a partir da década de 1970, compreendia a construção civil como um setor atrasado em relação a outras esferas produtivas do país devido à sua baixa produtividade, baixa mecanização e às situações bastante precárias de trabalho e de organização da produção. A superação do atraso só viria, de acordo com esses estudos ${ }^{5}$, com a industrialização da construção, através da aplicação da seriação e da mecanização. Mais recentemente, moldou-se uma segunda tendência no debate sobre o setor da construção. Tais estudos 6 demonstram que diversas estratégias de racionalização foram aplicadas dentro das

\footnotetext{
2 Diversos estudos tomaram o PMCMV como objeto de análise. Podemos destacar os trabalhos de Ferreira (2012), Cardoso (2013), Shimbo; Lopes (2014), Amore; Shimbo; Rufino (2015).

3 O Instituto de Pesquisas Econômicas Aplicadas (IPEA) desenvolveu um estudo sobre o MCMV debatendo seu caráter econômico. IPEA (2013).

${ }^{4}$ Apesar de existirem algumas diferenças e especificidades entre os argumentos dos autores que enquadramos na mesma tendência, consideramos que, do ponto de vista analítico, tal divisão facilita a compreensão das questões a serem aqui tratadas.

${ }^{5}$ Dentro da primeira tendência de debate enquadramos os seguintes estudos: Bruna (1976); Vargas (1981); Fleury e Vargas (1983); Maricato (1984); Vargas (1992).

${ }^{6} \mathrm{Na}$ segunda tendência de debate inserimos os estudos de Farah (1992); Farah (1996); Barone (1999); Koury (2007); Villela (2007); Moura (2011; Shimbo (2012); Baravelli (2014).
} 
atividades da construção civil nas últimas décadas, de modo que a tese do atraso do setor não se sustenta. Por apresentar especificidades em relação a outros setores produtivos, a construção civil não necessariamente deveria se desenvolver sob os preceitos clássicos da industrialização, como apontavam as análises anteriores. Justamente é dentro da segunda tendência do debate que enquadramos nossos estudos, sob a chave da racionalização.

\section{Questões, objetivos e método}

A partir do objetivo de identificar diferentes tendências de industrialização nos canteiros de obras da habitação em grande escala no Brasil no início dos anos 2000, seguimos três abordagens metodológicas de pesquisa ${ }^{7}$ : a pesquisa bibliográfica; a pesquisa de campo; e a pesquisa documental. A pesquisa bibliográfica foi direcionada à análise de conceitos relevantes dentro do debate sobre a indústria da construção. Também foi essencial compreender como a promoção da habitação atingiu a escala da produção em massa, do ponto de vista das políticas habitacionais. Em relação à pesquisa de campo, desde a formulação inicial deste projeto, se desenhava a intenção de investigar a prática da construção habitacional. Para isso se faziam necessárias as visitas aos canteiros de obras de empreendimentos habitacionais de grande escala e a realização de entrevistas. Finalmente, a pesquisa documental teve enfoque nos relatórios e documentos das empresas construtoras, com objetivo de analisar estratégias, desempenho e organização. Em relação à escolha dos canteiros de obras para análise seguimos os seguintes critérios: i) abertura da empresa construtora e autorização para acompanhamento da obra; ii) grande porte do canteiro de obras; iii) empreendimentos que ainda estivessem em processo de construção; iv) localização geográfica -empreendimentos inseridos na região de São Carlos, por ser o local de desenvolvimento da pesquisa e, portanto, de fácil acesso.

\footnotetext{
7 Como método, utilizamos a pesquisa qualitativa. “Com o termo 'pesquisa qualitativa', queremos dizer qualquer tipo de pesquisa que produza resultados não alcançados através de procedimentos estatísticos ou de outros meios de quantificação". (STRAUSS; CORBIN, 2008, p.23)
} 
A pesquisa de campo foi realizada em cinco canteiros de obras, com a finalidade de compreender a dinâmica de trabalho, as tecnologias empregadas e os sistemas de controle. Os dados foram coletados a partir de observações de campo, conversas informais com os trabalhadores das obras, entrevistas semi-estruturadas e registros fotográficos dos canteiros. Algumas questões nortearam as visitas de campo: Como se viabilizou a produção das edificações no canteiro? Houve perspectiva de industrialização? Ou então, estratégias de racionalização?

Duas empresas construtoras foram objetos de análise. Uma delas, uma grande empresa de capital aberto e de atuação nacional. A outra, de médio porte, atua na região de São Carlos, no interior do estado de São Paulo. Chamaremos a grande empresa de 'Empresa Nacional' e a média empresa de 'Empresa Regional'. Apesar de terem portes e atuações distintos, ambas as construtoras têm foco na produção em larga escala da habitação.

Dos cinco empreendimentos analisados, dois deles eram conjuntos de casas térreas, executados pela Empresa Regional com o sistema construtivo de paredes de concreto. Os outros três empreendimentos eram conjuntos de blocos de apartamentos executados pela Empresa Nacional - um deles em alvenaria estrutural e os outros dois em paredes maciças de concreto. Optamos por não citar os nomes dos empreendimentos, e utilizamos as características citadas acima para desenvolver siglas para cada um dos canteiros estudados. Apresentaremos os empreendimentos a partir da abreviação de seu respectivo sistema construtivo - "ALV" para alvenaria estrutural e "PC" para paredes de concreto -, seguido da abreviação de sua respectiva tipologia - "APTO" para apartamento e "CASA" para casa térrea.

Dentro do conjunto analisado, que teve como característica comum a larga escala dos empreendimentos, existiam algumas variáveis que se diferenciavam como, por exemplo, o número de unidades por canteiro e a própria densidade construtiva de cada empreendimento, que estavam relacionadas diretamente à tipologia dos empreendimentos. Duas tipologias foram analisadas: casas térreas e blocos de apartamentos. Enquanto os canteiros das casas térreas são grandes terrenos de mais de $200.000 \mathrm{~m}^{2}$, os empreendimentos de apartamentos têm área total em torno de $30.000 \mathrm{~m}^{2}$. Portanto, as obras de apartamentos têm densidade construtiva superior às obras de casas térreas. A taxa de ocupação, entretanto é maior nos conjuntos de casas.

O quadro a seguir apresenta detalhadamente esses dados: 
Quadro 1 - Características dos canteiros de obras estudados.

\begin{tabular}{|c|c|c|c|c|c|}
\hline & $\begin{array}{l}\text { Canteiro } 1 \\
\text { ALV_APTO }\end{array}$ & $\begin{array}{l}\text { Canteiro } 2 \\
\text { PC_APTO_1 }\end{array}$ & $\begin{array}{l}\text { Canteiro } 3 \\
\text { PC_APTO_2 }\end{array}$ & $\begin{array}{l}\text { Canteiro } 4 \\
\text { PC_CASA_1 }\end{array}$ & $\begin{array}{l}\text { Canteiro } 5 \\
\text { PC_CASA_2 }\end{array}$ \\
\hline Construtora & Nacional & Nacional & Nacional & Regional & Regional \\
\hline $\begin{array}{l}\text { Sistema } \\
\text { construtivo }\end{array}$ & $\begin{array}{l}\text { Alvenaria } \\
\text { estrutural }\end{array}$ & $\begin{array}{l}\text { Paredes de } \\
\text { concreto }\end{array}$ & $\begin{array}{l}\text { Paredes de } \\
\text { concreto }\end{array}$ & $\begin{array}{l}\text { Paredes de } \\
\text { concreto }\end{array}$ & $\begin{array}{ll}\text { Paredes de } \\
\text { concreto }\end{array}$ \\
\hline Tipologia & Apartamento & Apartamento & Apartamento & Casa & Casa \\
\hline Pavimentos & 5 & 4 & 4 & 1 & 1 \\
\hline $\begin{array}{l}\text { Número de } \\
\text { unidades }\end{array}$ & 720 & 356 & 532 & 986 & 618 \\
\hline $\begin{array}{l}\text { Área das } \\
\text { unidades }\left(\mathrm{m}^{2}\right)\end{array}$ & 42 & 39 & 42 & 36 & 44 \\
\hline $\begin{array}{l}\text { Lote individual } \\
\left(\mathrm{m}^{2}\right)\end{array}$ & --- & --- & --- & 160 & 200 \\
\hline Terreno $\left(\mathrm{m}^{2}\right)$ & 31.000 & 20.000 & 54.500 & 432.000 & 262.500 \\
\hline $\begin{array}{ll}\text { Área } & \text { total } \\
\text { construida }-A C \\
\left(\mathrm{~m}^{2}\right)\end{array}$ & 30.240 & 13.884 & 22.344 & 157.800 & 123.600 \\
\hline $\begin{array}{l}\text { Coeficiente de } \\
\text { Aproveitamento } \\
\text { (AC/terreno) }\end{array}$ & 0,97 & 0,70 & 0,40 & 0,36 & 0,47 \\
\hline $\begin{array}{l}\text { Ocupação térreo } \\
\left(\mathrm{m}^{2}\right)\end{array}$ & 8.500 & 5.200 & 7.800 & 157.800 & 123.600 \\
\hline $\begin{array}{l}\text { Taxa de } \\
\text { ocupação (\%) }\end{array}$ & 27,4 & 26 & 14,3 & 36,5 & $47 \%$ \\
\hline $\begin{array}{l}\text { Densidade } \\
\text { (terreno/no de } \\
\text { unidades) }\end{array}$ & $43 \mathrm{~m}^{2} / \mathrm{un}$ & $56 \mathrm{~m}^{2} / \mathrm{un}$ & $102 \mathrm{~m}^{2} / \mathrm{un}$ & $438 \mathrm{~m}^{2} / \mathrm{un}$ & $424 \mathrm{~m}^{2} / \mathrm{un}$ \\
\hline $\begin{array}{l}\text { № de módulos } \\
\text { da construção }\end{array}$ & 3 & 2 & 2 & 2 & 5 \\
\hline PMCMV & Faixa 2 & Faixa 2 & Faixa 2 & Faixa 1 & Faixa 2 \\
\hline
\end{tabular}

\section{OBSERVAÇÕES}

Todas as metragens estão aproximadas, pois não foi possivel coletar os dados executivos de todas as obras. Deste modo algumas medidas foram estimadas de acordo com o material disponível.

Para definir a área ocupada do terreno, nos empreendimentos de tipologia apartamentos, foi utilizada a soma das áreas construídas dos primeiros pavimentos. Já nos empreendimentos de casas térreas, a área ocupada foi definida pela soma das áreas totais dos lotes, não somente das casas.

Não foram contabilizadas para a metragem da ocupação, e, portanto, para a densidade, as áreas das edificações institucionais dos empreendimentos, uma vez que não foi possível obter este levantamento de todas as obras.

FONTE: Elaboração própria a partir de dados coletados na pesquisa de campo e nos sites das construtoras. Julho/2017.

A seguir apresentaremos a caracterização geral de cada empreendimento, com as informações mais relevantes. As informações secundárias - inserção urbana, implantação e planta baixa dos empreendimentos - se encontram no ANEXO 1. A análise das empresas será apresentada em seguida à caracterização dos empreendimentos. Foi realizada com 
base nas informações coletadas nas visitas aos canteiros e também na pesquisa documental ${ }^{8}$.

\section{Canteiro 1 - ALV_APTO}

O empreendimento ALV_APTO, da Empresa Nacional, localiza-se na região sudeste da cidade de São Carlos/SP, em uma área predominantemente industrial e comercial. A obra foi iniciada em outubro de 2012 e concluída em junho de 2015. São 720 unidades habitacionais, distribuídas em 36 blocos de apartamentos, com cinco pavimentos cada, construídos em alvenaria estrutural. Os apartamentos de aproximadamente $42 \mathrm{~m}^{2}$ tem dois dormitórios, um banheiro, sala e cozinha. As unidades do térreo contavam ainda com uma área descoberta privativa. 0 empreendimento se enquadra na faixa 2 do PMCMV 9 .

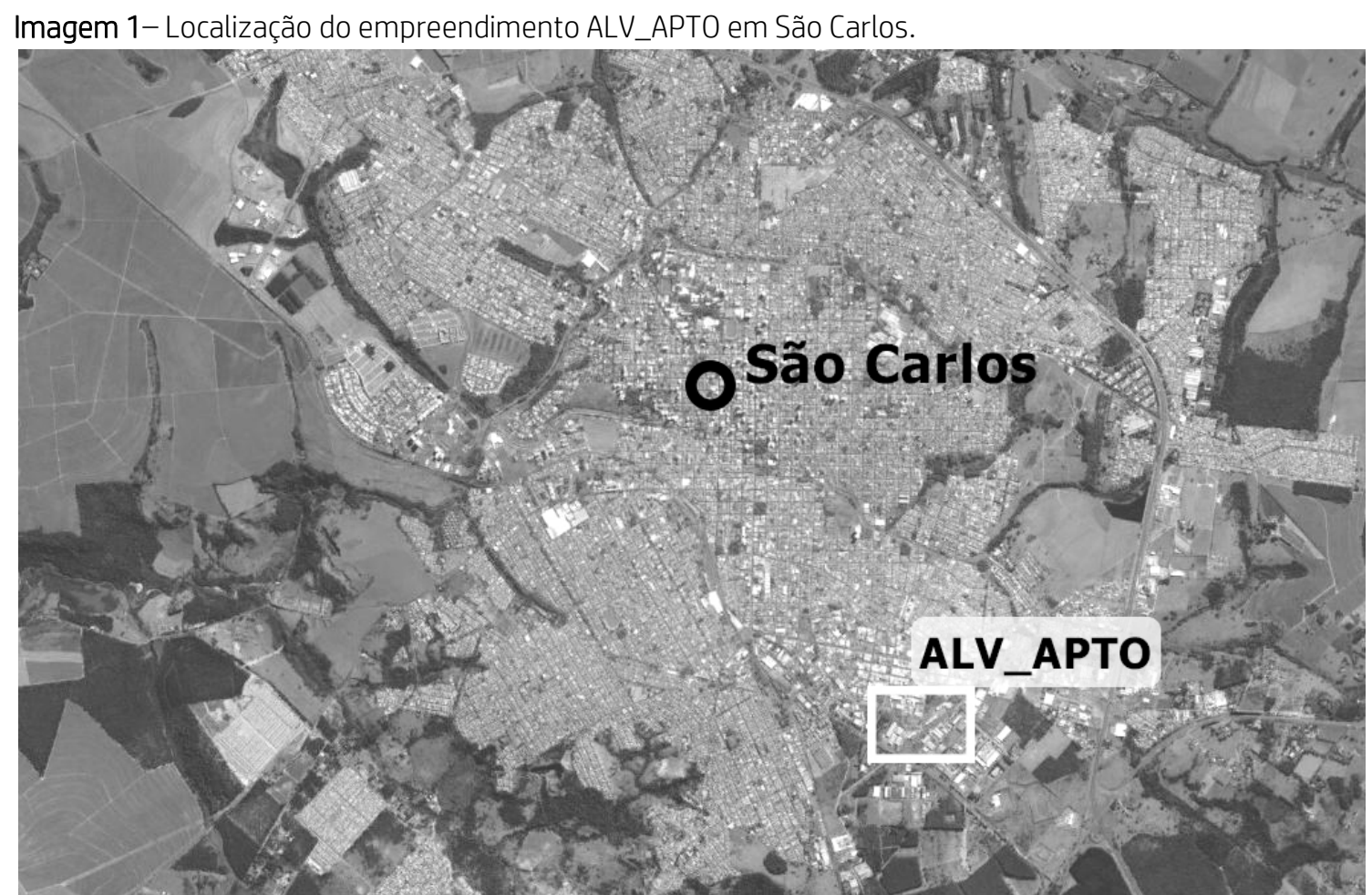

FONTE: Elaboração própria a partir de imagem do Google Earth. Acesso em: 07/2017.

\footnotetext{
8 Foram consultados os sites das empresas, Relatórios Financeiros, Reportagens e Entrevistas.

${ }^{9}$ A política de atendimento do PMCMV é organizada de acordo com as faixas de renda das famílias contempladas. Nas fases 1 e 2 do programa, existiam três faixas de renda. Atualmente, na fase 3, o PMCMV é divido em quatro faixas de renda, sendo que os valores foram ajustados em relação às fases anteriores. As quatro divisões são: Faixa 1 - até R\$1.800,00; Faixa 1,5 - até R\$ 2.600,00; Faixa 2 - até $R \$ 4.000,00$; Faixa 3 - até R\$9.000,00. Disponível em: <http://www.minhavidaminhacasa.com/regulamento-minha-casa-minha-vida/>. Acesso em: jan/2018.
} 


\section{Canteiro 2 - PC_APTO_1}

O empreendimento PC_APTO_1, da Empresa Nacional, localiza-se na cidade de Araraquara/SP em uma área periférica, muito próxima à rodovia Washington Luis e à margem de um bairro residencial. A obra foi iniciada em agosto de 2016 e até o momento de escrita desta dissertação (fevereiro de 2018) a obra ainda não havia sido concluída. São 356 unidades habitacionais, distribuídas em 22 blocos de apartamentos, sendo um deles para portadores de necessidades especiais (PNE). Somente os apartamentos para PNE terão $50 \mathrm{~m}^{2}$, os demais terão aproximadamente $40 \mathrm{~m}^{2}$. O bloco PNE também é o único que terá 5 pavimentos e elevador, todos os outros terão 4 pavimentos sem elevador. São apartamentos de dois dormitórios, um banheiro, sala e cozinha. 0 empreendimento se enquadra na faixa 2 do PMCMV.

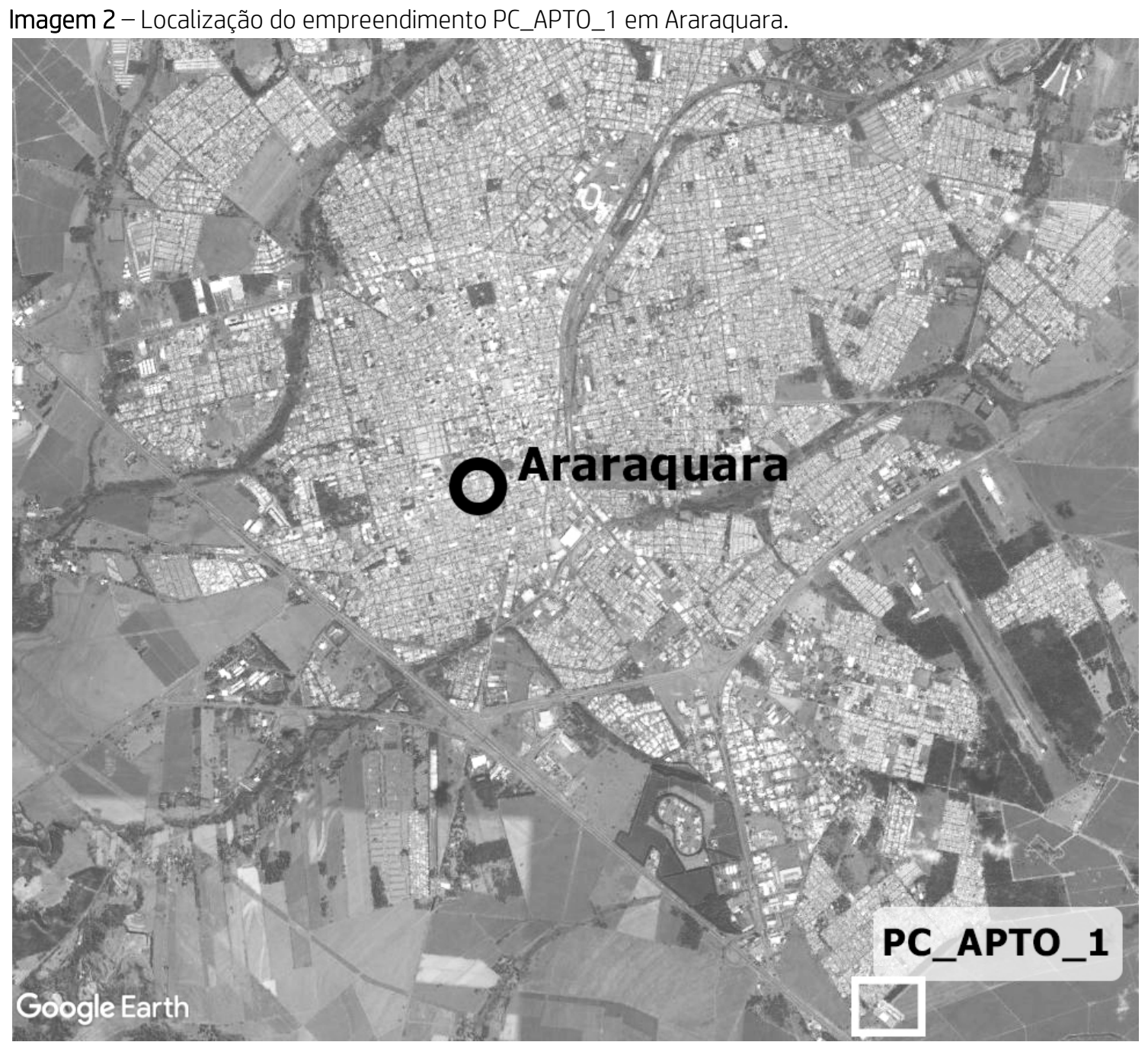

FONTE: Elaboração própria a partir de imagem do Google Earth. Acesso em: 07/2017. 
Canteiro $3-P C_{-} A P T_{-} 2$

O empreendimento PC_APTO_2, da Empresa Nacional, localiza-se na cidade de São Carlos/SP, em uma região periférica, margeada pela rodovia Washington Luis. No entorno existem condomínios residenciais de alto padrão, loteamentos residenciais e o Centro Universitário Central Paulista (UNICEP). São 532 unidades habitacionais, distribuídas em 33 blocos de apartamentos com quatro pavimentos, sendo um deles PNE. Apenas o bloco PNE possui 5 pavimentos e elevador, os outros 32 são blocos de 4 pavimentos. Os apartamentos têm de 41 a $47 \mathrm{~m}^{2}$. 0 empreendimento se enquadra na faixa 2 do PMCMV.

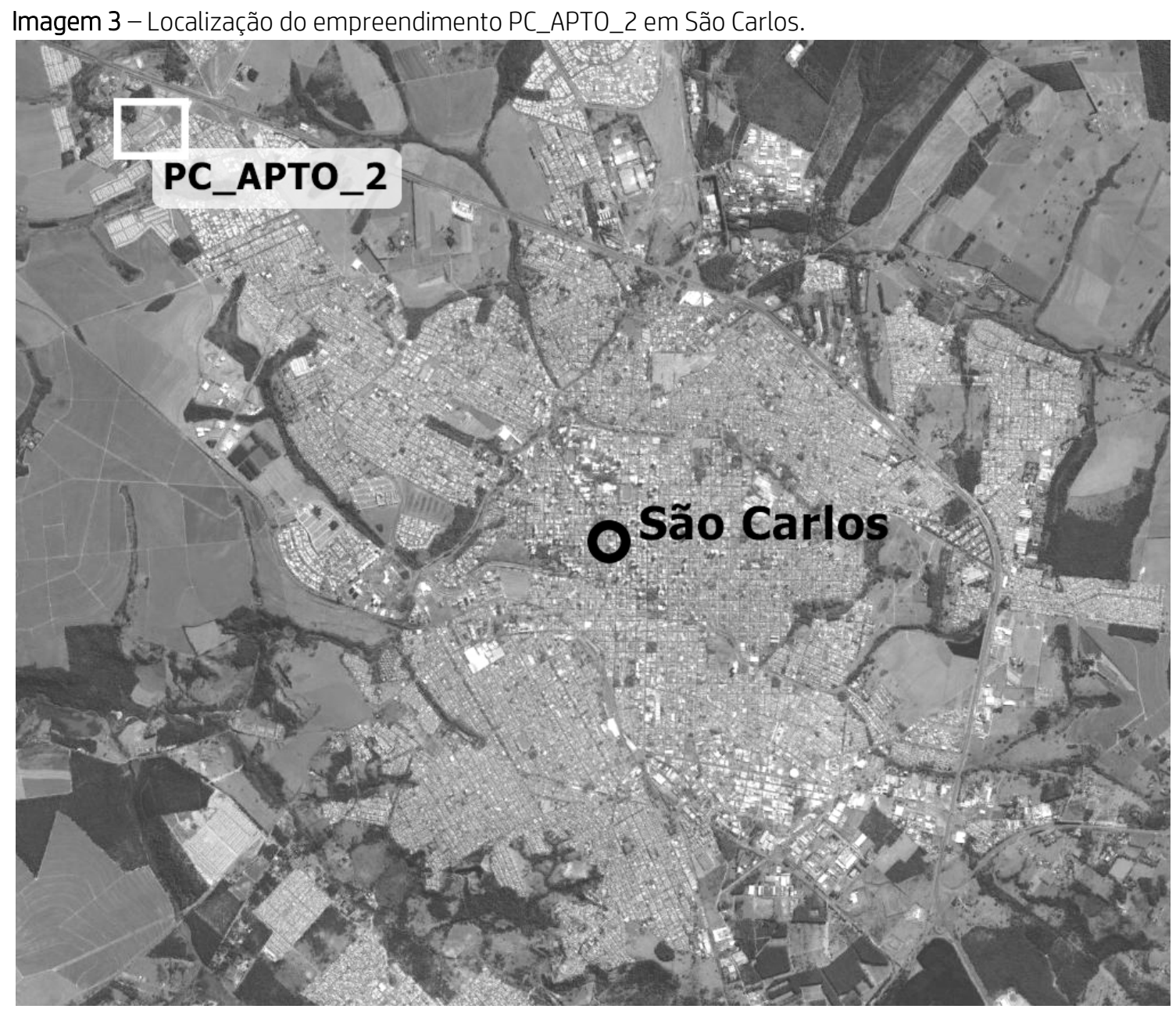

FONTE: Elaboração própria a partir de imagem do Google Earth. Acesso em: 07/2017. 


\section{Canteiro 4 - PC_CASA 1}

O empreendimento PC_CASA_1, da Empresa Regional, está localizado na região sudoeste de São Carlos/SP, em uma área predominantemente rural. A obra foi iniciada em abril de 2014 e a previsão de entrega era de 18 meses, ou seja, outubro de 2015. Tal previsão foi cumprida e a obra foi entregue sem atrasos. Compreende 986 unidades de casas térreas de $36 \mathrm{~m}^{2}$ e o loteamento ocupa a área de aproximadamente $435.000 \mathrm{~m}^{2}$. O lote de cada unidade habitacional tem 8 metros de largura e 20 metros de comprimento, totalizando uma área de $160 \mathrm{~m}^{2}$. Todas as unidades têm a mesma tipologia - casas térreas com dois dormitórios, banheiro, sala, cozinha e lavanderia externa. 0 empreendimento se enquadra na faixa 1 do PMCMV. Entre os casos estudados, é o único destinado a famílias de menor renda mensal.

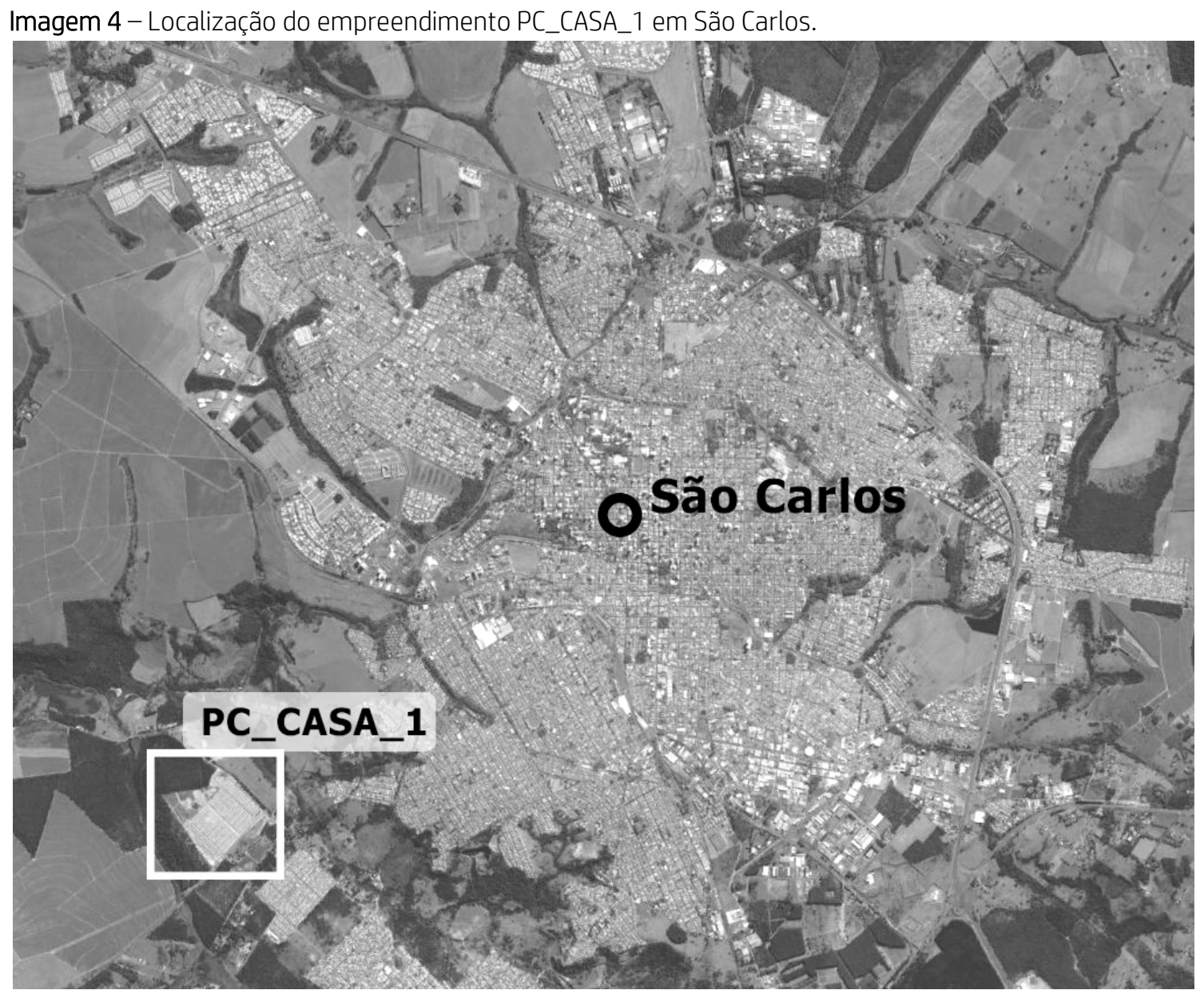

FONTE: Elaboração própria a partir de imagem do Google Earth. Acesso em: 07/2017. 
Canteiro 5 - PC_CASA 2

O PC_CASA_2 localiza-se na periferia da cidade de Araraquara/SP. A obra foi iniciada em março de 2016 e a previsão para conclusão era de dois anos e, portanto, não havia sido concluída até o momento de redação da dissertação. São 618 casas térreas de aproximadamente $44 \mathrm{~m}^{2}$, implantadas em lotes de $200 \mathrm{~m}^{2}$ (8 x $25 \mathrm{~m}$ ). A obra será entregue com a infraestrutura completa (pavimentação, rede esgoto, lagos de contenção, etc). 0 empreendimento se enquadra na faixa 2 do PMCMV.

Imagem 5 - Localização do empreendimento PC_CASA_2 em Araraquara.

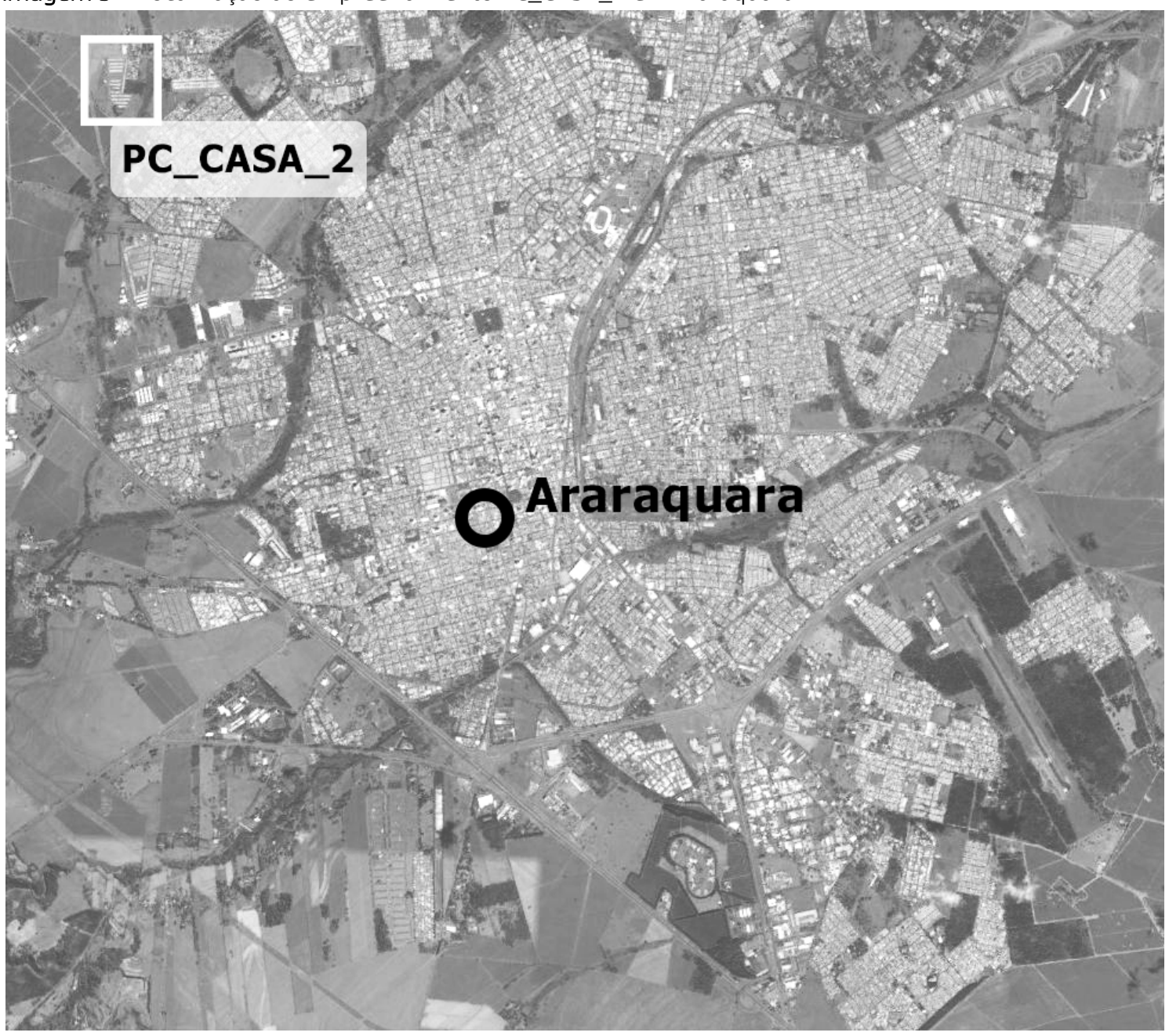

FONTE: Elaboração própria a partir de imagem do Google Earth. Acesso em 07/2017. 


\section{A Empresa Nacional}

Fundada em 1979 e com sede em Belo Horizonte/MG, a Empresa Nacional ${ }^{10}$ é considerada atualmente uma das maiores construtoras da América Latina. Seu foco de atuação é justamente a produção da habitação voltada ao segmento econômico. 0 bom desempenho nesse ramo de produção é justificado pela empresa através de seu modelo integrado de gestão, sua capacidade de aquisição de terrenos, a construção industrializada, a padronização dos imóveis e ciclo operacional mais curto.

No ano de 2007 a Nacional abriu seu capital na Bolsa de Valores ${ }^{11}$, após um período de preparação que buscou delimitar a atuação da empresa apenas nas atividades de construção e incorporação imobiliária e também reestruturar o corpo administrativo da empresa. Foram realizadas duas ofertas aos acionistas, sendo que os recursos da primeira oferta foram destinados à aquisição de terrenos e à atividade de incorporação e os da segunda oferta serviram para garantir a execução dos empreendimentos (SHIMBO, 2012).

Uma década após a abertura de capital, a Empresa Nacional vem se destacando no cenário nacional, alcançando as primeiras colocações nas pesquisas de desempenho entre as empresas construtoras de edificações ${ }^{12}$ e também nas do mercado imobiliário. A construtora também recebeu algumas certificações importantes para o ramo da construção, como a ISO ${ }^{13} 14.001$ - que se refere à gestão do meio ambiente; e a OHSAS ${ }^{14}$ 18.001 - que se refere a questões de segurança e saúde dos trabalhadores nas empresas; o nível A do Programa Brasileiro de Qualidade e Produtividade na Habitação - PBQP-H15 e o selo ISO 9001. As certificações e os selos de qualidades são peças importantes no

\footnotetext{
${ }^{10}$ A análise da Empresa Nacional aqui apresentada é resultado da pesquisa documental (realizada a partir de demonstrações financeiras e relatórios anuais divulgados pela empresa nacional, sendo que divulgação dos resultados financeiros é uma exigência do Novo Mercado da Bovespa). A Nacional foi pesquisada pela orientadora deste mestrado anteriormente, o que me permitiu a continuação de seu trabalho analítico. Desse modo, foram compiladas informações de treze anos de pesquisa sobre a Nacional, de 2004 a 2017.

11 Cabe ressaltar que a Nacional sempre trabalhou no mercado de habitação para baixa renda, o que inclusive foi um fator que dificultou a entrada da empresa no universo do capital financeiro, sendo necessário um trabalho de convencimento dos investidores de que o mercado do segmento econômico poderia dar lucro.

12 Destaque para a o ranking de Inteligência Empresarial da Construção (ITC).

13 ISO é a sigla de International Organization for Standardization.

14 OHSAS (Occupational Health and Safety Assessment Series) é uma norma de Sistema de Gestão de Segurança e Saúde Ocupacional

15 O PBQP-H, por exemplo, foi criado em 1997 como um programa de certificação que serviria como requisito para que as empresas tivessem acesso a financiamentos.
} 
universo do mercado financeiro, sendo que os investimentos e financiamentos frequentemente dependem do desempenho da empresa nesses indicadores.

Principalmente a partir de 2006, a Empresa Nacional passou por um intenso processo de expansão. A abertura do capital impulsionou seu crescimento após 2007, uma vez que a construtora havia se comprometido com seus investidores a quadruplicar as unidades lançadas até o ano de 2010. Até o ano de 2005 a Nacional atuava em 27 cidades. Em 2009, ano de implementação do PMCMV, já estava presente em 75 cidades. Atualmente atua em mais de 140 municípios, em todas as regiões do Brasil.

Além de sua expansão geográfica, a Nacional ampliou vertiginosamente seu desempenho econômico desde que abriu seu capital, em 2007. De acordo com Shimbo (2012), foi um momento de "crescimento agressivo", no qual a empresa multiplicou por 15 o número de unidades lançadas. No ano de 2010, a Nacional atingiu 47.000 unidades lançadas. Em seguida, diminui o número de lançamentos - que chegou a 26.000 unidades em 2016 mas ampliou seu valor de vendas. Em 2017, entretanto, o número de lançamentos voltou a crescer consideravelmente, chegando a mais de 37.000 unidades.

Se o ápice no número de lançamentos da empresa ocorreu em 2010, foi em 2011 que a empresa nacional atingiu seu lucro líquido mais exorbitante. A partir de 2012, entretanto, o lucro da empresa caiu consideravelmente. No ano de 2014, em contrapartida, o lucro da Nacional voltou a subir cerca de 70\% e, finalmente em 2015 caiu 23\%. Já em 2016 houve um pequeno crescimento. Até o momento não havia sido divulgado o lucro líquido de 2017.

Outra questão pertinente é que a partir de 2007, a Nacional investiu consideravelmente em seu banco de terrenos, o que foi essencial para garantir seu projeto de expansão. Um dos fatores mais importantes na produção habitacional é o preço da terra, uma vez que impacta significativamente no valor de determinado empreendimento. Possuir uma grande quantidade de terrenos, para uma incorporadora e construtora, significa ter um grande potencial construtivo. Este valor, no caso, é medido pelo Valor Geral de Vendas, o VGV. Com o valor do banco de terrenos, é possível saber qual o potencial da empresa, quantas unidades e quantos empreendimentos ela poderia construir em determinada 
porção de território. 0 banco de terrenos se coloca, portanto, como uma garantia para o investidor ${ }^{16}$.

O quadro a seguir apresenta detalhadamente o desempenho da empresa entre 2004 e 2017.

Quadro 2 - Valores de VGV, de Vendas Contratadas e lucro líquido da Empresa Nacional (2004-2016).

\begin{tabular}{|c|c|c|c|c|c|c|}
\hline Ano & $\begin{array}{c}\text { № de } \\
\text { unidades } \\
\text { lançadas }\end{array}$ & $\begin{array}{l}\text { № de } \\
\text { unidades por } \\
\text { canteiro } \\
\text { (média) }\end{array}$ & VGV (R\$ Mil) & $\begin{array}{c}\text { Vendas (R\$ } \\
\text { Mil) }\end{array}$ & $\begin{array}{c}\text { № de } \\
\text { unidades } \\
\text { vendidas }\end{array}$ & $\begin{array}{l}\text { Lucro Líquido } \\
\text { (R\$ Mil) }\end{array}$ \\
\hline 2004 & 1.618 & 58 & 133.078 & 101.846 & 1.506 & 14.000 \\
\hline 2005 & 1.769 & 39 & 189.458 & 112.127 & 1.361 & 23.600 \\
\hline 2006 & 2.987 & 47 & 346.675 & 212.951 & 2.079 & 17.000 \\
\hline 2007 & 11.137 & 89 & 1.199 .948 & 717.030 & 6.602 & 87.100 \\
\hline 2008 & 23.474 & 128 & 2.532 .985 & 1.544 .224 & 14.500 & 231.030 \\
\hline 2009 & 25.500 & 183 & 2.586 .100 & 2.821 .800 & 28.000 & 347.400 \\
\hline 2010 & 47.000 & 219 & 4.604 .000 & 3.753 .000 & 36.000 & 634.500 \\
\hline 2011 & 42.000 & 283 & 4.600 .000 & 4.322 .000 & 39.000 & 760.000 \\
\hline 2012 & 30.000 & 313 & 3.400 .000 & 4.005 .000 & 34.000 & 528.000 \\
\hline 2013 & 25.516 & 322 & 3.500 .000 & 5.094 .000 & 38.449 & 423.000 \\
\hline 2014 & 29.297 & 296 & 4.354 .000 & 6.013 .000 & 41.325 & 720.000 \\
\hline 2015 & 31.871 & 389 & 4.704 .000 & 5.497 .000 & 35.782 & 548.000 \\
\hline 2016 & 26.366 & 322 & 3.987 .000 & 5.259 .000 & 34.082 & 557.000 \\
\hline $2017^{*}$ & 37.155 & --- & 5.627 .000 & 6.055 .000 & 40.512 & --- \\
\hline
\end{tabular}

* Até o momento de escrita desta dissertação ainda não haviam sido divulgadas todas as informações sobre o desempenho da Empresa Nacional em 2017

Fonte: Elaboração própria a partir de relatórios financeiros da Empresa Nacional e de SHIMBO (2012).

16 Sobre a questão da terra como ativo financeiro na produção capitalista do espaço, ver: Fix, Mariana. Financeirização e transformações recentes no circuito imobiliário no Brasil. Tese de Doutorado. Campinas, Instituto de Economia, Universidade Estadual de Campinas, 2011; 
Esses dados demonstram, primeiramente, que a Nacional busca um equilíbrio entre seus lançamentos e suas vendas. No ano de 2014, por exemplo, foram lançadas 29.000 unidades e foram vendidas 41.000, o que indica que a empresa estava reduzindo seu estoque. Recentemente, no ano de 2017, tanto o número de lançamentos quanto o de vendas - que haviam caído em 2016 - voltaram a subir. 0 gráfico a seguir demonstra a relação entre o VGV e as vendas contratadas (em R \$ milhões) da Empresa Nacional.

\section{Gráfico 1 - VGV versus Vendas Contratadas da Empresa Nacional (2004-2017), em R\$ milhões.}

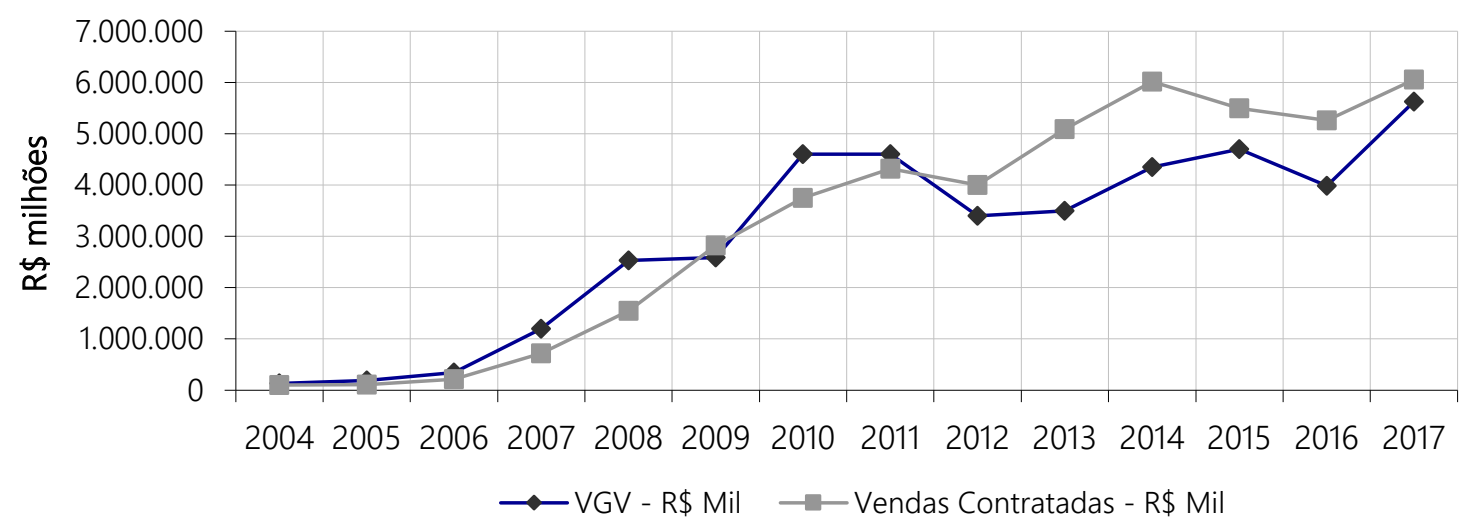

FONTE: Elaboração própria a partir de relatórios financeiros da Empresa Nacional.

É importante ressaltar também que a Nacional tem vínculo bastante estreito com o PMCMV, sendo que a maior parte de sua produção se enquadra no Programa, nas faixas voltadas à média renda. 0 fundador da Empresa, inclusive teve participação ativa na formatação do PMCMV. Além do empresário, outros seis integrantes importantes do setor imobiliário do país se juntaram à Dilma Rousseff em 2008 - à época Ministra da Casa Civil - para discutir alguns parâmetros do Programa ${ }^{17}$.

\footnotetext{
${ }^{17}$ Entrevista com o fundador da Nacional. "Não vamos aguentar por muito mais tempo". 0 Estado de São Paulo. 08 nov. 2015.
} 
Em relação à sua estrutura organizacional, a Empresa Nacional é segmentada entre Conselhos, Diretorias, Comitês e Departamentos. Tal modelo é frequentemente adotado por grandes empresas, que contam com a participação de acionistas. Atualmente, a empresa conta com 10 diretores, 24 gestores, 55 coordenadores, 340 engenheiros, 904 auxiliares de engenharia e técnicos em edificações e estagiários, além de mais de 18.882 outros trabalhadores, sendo 9.874 próprios e 8.393 terceirizados ${ }^{18}$. Diversos departamentos se concentram na sede da empresa e coordenam as regionais. As regionais, por sua vez, são responsáveis por várias cidades e em cada cidade existem os engenheiros de controle que verificam algumas obras.

Cada obra tem o seu escritório próprio, com um ou mais engenheiros responsáveis dependendo do porte do empreendimento. A regional de Ribeirão Preto, por exemplo, é responsável por algumas cidades como Franca, Sertãozinho, Araraquara, São Carlos, entre outras. Dentro de cada regional existe uma equipe responsável pela cadeia de suprimentos ${ }^{19}$.

As atividades de vendas são realizadas por uma equipe própria de corretores e de imobiliárias parceiras da construtora, além de ter havido um grande crescimento das vendas feitas pela internet. Segundo dados do Relatório Financeiro da empresa de 2013 o website da Nacional recebeu 31 milhões de visitas e foi o responsável por 30\% das vendas contratadas.

\section{A Empresa Regional}

A Empresa Regional 20 é uma construtora e incorporadora atuante no interior do estado de São Paulo. Seu foco é a produção de empreendimentos habitacionais com elevado número de unidades, tanto de tipologia de apartamento quanto de casas. A empresa possui certificação ISO 9001 e PBQP-H nível A. Suas bandeiras são alta qualidade das

\footnotetext{
${ }^{18}$ APRESENTAÇÃO INSTITUCIONAL da Empresa Nacional. Jan. 2018.

19 Organograma da Empresa Nacional: ver anexo 2.

20 Diferentemente da Empresa Nacional, a regional não tem capital aberto. Não é possível, portanto, ter acesso a informações detalhadas sobre seu desempenho dentro do mercado imobiliário. Nesse sentido, para a análise da Empresa Regional contamos com informações coletadas durante as visitas de campo e também aquelas disponibilizadas no site da empresa.
} 
obras e cumprimento de prazos, além da utilização do sistema construtivo de paredes e lajes de concreto que a empresa apresenta como garantia de qualidade, padronização e agilidade de execução ${ }^{21}$.

Com sede em São Carlos a construtora conta atualmente com cerca de 400 funcionários e um único proprietário. Além da sede, a Regional tem um pequeno escritório em Piracicaba que serve como apoio para atividades na região. Recentemente, a empresa firmou uma parceria com uma grande construtora de atuação expressiva no nordeste do país.

A hierarquia máxima da empresa, a diretoria geral, é de responsabilidade do proprietário da construtora. Abaixo da diretoria geral, existe o setor administrativo, divido em seis departamentos: controladoria; jurídico; recursos humanos; financeiro; obras por administração e contratos; Tecnologia da Informação (T.I.) A diretoria geral, por sua vez, tem dois campos de atuação: um responsável pelas questões imobiliárias e outro pela parte da engenharia. Cada obra tem ao menos um engenheiro responsável, além de auxiliares e estagiários. Acima dos engenheiros existem apenas dois diretores de engenharia - responsáveis pela supervisão das obras - e o próprio dono da empresa ${ }^{22}$.

Os 'negócios imobiliários' cuidam do marketing, da prospecção dos negócios, da incorporação e das vendas. 0 departamento da engenharia vai efetivamente tratar da produção da empresa, através dos seguintes campos: qualidade; assistência técnica; suprimentos; segurança do trabalho; processos técnicos; projetos; orçamento; planejamento. Ainda inseridas na área da diretoria de engenharia, estão as equipes responsáveis pela coordenação de obras.

De acordo com o portfólio disponibilizado no site da empresa, foram executados 35 empreendimentos no interior do estado de São Paulo. Dentre os empreendimentos residenciais, mais de $80 \%$ correspondem aos conjuntos de apartamentos e casas. Esse dado demonstra o padrão adotado pela empresa. Esses dois tipos de empreendimentos têm elevado número de unidades e geralmente são voltados para o segmento econômico.

21 Informações coletadas no site da construtora. Acesso em: ago. 2016.

22 Organograma da Empresa Regional: ver anexo 2. 
Em relação ao número de unidades, a Empresa Regional já produziu aproximadamente 11 mil unidades. Nesse aspecto, a maior parte da produção é de casas térreas - 5.665 unidades - e, em seguida, blocos de apartamentos - 4.667 unidades. 0 número médio de unidades nos canteiros dos empreendimentos de casas térreas é de 566,5 enquanto nos de blocos de apartamentos fica próximo a 260.

A produção da empresa regional se concentra no interior do estado de São Paulo, principalmente nas cidades de São Carlos e Piracicaba. Em algumas cidades, a regional executou apenas um empreendimento. É o caso de Rio Claro, Sumaré, Louveira, São João da Boa Vista, Araraquara, Hortolândia e Ribeirão Preto.

No portfólio da empresa não são apresentadas as datas de lançamento e de conclusão dos empreendimentos. É possível aferir com base em reportagens e dados das prefeituras, entretanto, que os maiores conjuntos habitacionais foram entregues depois de 2010. 0 maior empreendimento realizado pela Regional é um conjunto de 1000 casas térreas na cidade de São Carlos e foi entregue em 2011. É possível citar também o PC_CASA_1, um dos casos estudados, que tem 986 unidades e foi entregue em 2015. O PC_CASA_2, também estudado nesta pesquisa, está em processo de conclusão e tem 634 unidades habitacionais. Considerando-se apenas os empreendimentos concluídos em dezembro de 2017 e os que estão em processo de lançamento, o que totaliza seis empreendimentos, serão mais de 2.000 unidades produzidas pela Regional nas cidades de Araraquara, Piracicaba, Ribeirão Preto e São Carlos.. Trata-se de um indício de que a construtora ampliou sua produção na última década.

Recentemente a empresa regional incorporou à sua produção o sistema construtivo de paredes de concreto moldadas in-loco. Os empreendimentos mais recentes, principalmente os de maior escala, estão sendo executados com essa tecnologia. É uma questão importante uma vez que a implementação desse sistema exige alto investimento e capacitação técnica. Não foi possível aferir com detalhes, porém provavelmente a questão da implementação do "novo" sistema construtivo de paredes de concreto moldadas in-loco está relacionada a uma parceria realizada pela empresa regional com uma grande construtora de atuação nacional.

A grande construtora foi fundada em 1981, iniciando suas atividades na cidade de Belo Horizonte/MG. Atualmente a empresa atua em 12 estados brasileiros e no Distrito Federal, em todas as regiões do país. No ano de 2009 realizou a abertura do capital e teve, 
a partir daí, seu período de maior crescimento. Trata-se de uma das principais construtoras do país, tendo como foco principal a produção de empreendimentos populares de grande porte. Atua principalmente dentro da faixa 1 do $\mathrm{PMCMV}^{23}$.

Foi possível apurar que pelo menos três obras executadas em Piracicaba/SP foram resultado da parceria entre a regional e a grande construtora. A Regional funciona como uma porta de entrada no interior de São Paulo para a grande construtora, que por sua vez tem papel importante na compra das fôrmas de alumínio utilizadas para a execução das paredes de concreto.

É muito provável que na última década a diretoria tenha optado por ampliar o porte da Empresa Regional. A busca por uma parceria com a grande construtora também reforça essa hipótese. Além disso, a Regional se vinculou mais intimamente à produção de moradias voltada à baixa renda.

\section{Os resultados obtidos e organização da dissertação}

No início do desenvolvimento da pesquisa, buscamos analisar os dados a partir dos âmbitos interno e externo do canteiro de obras, o que chamamos de 'on-site' e 'off-site'24. Entretanto, tal divisão não se adequou ao teor das informações coletadas, que muitas vezes perpassava os dois campos. Partimos então para uma categorização norteada por algumas noções construídas por Jaramillo (1987): trabalho direto; controle técnico da produção; controle econômico direto da produção; e controle econômico indireto da produção.

O trabalho direto é a ponta final da cadeia, ou seja, dentro da produção de um empreendimento habitacional é 'quem faz' e 'como faz'. Essa categoria engloba os processos de execução, os trabalhadores envolvidos, as máquinas e as ferramentas utilizadas, os insumos, etc. Já o controle técnico da produção é o que efetivamente exerce

\footnotetext{
23 Site da grande construtora. Acesso em: jan. 2018.

24 Essa divisão das categorias analíticas em dois campos principais (on-site e off-site) foi proposta por Lucia Shimbo, em seu Projeto de Pesquisa apresentado à Chamada Universal MCTI/CNPq № 01/2016 - Faixa A. Dentro de cada campo, entretanto, adaptamos as subcategorias, a partir de uma classificação que se encaixasse mais especificamente em nossa observação de campo.
} 
controle sobre o trabalho direto, ou seja, quem controla e como controla. 0 controle econômico direto da produção refere-se aos agentes que têm o domínio dos meios de produção e o poder econômico interno e, a partir dele, interferem diretamente na produção. 0 controle econômico indireto, por sua vez, também tem a ver com o poder econômico, porém externo à produção (JARAMILLO, 1987).

Principalmente as duas primeiras categorias de Jaramillo (1987) - trabalho direto e controle técnico da produção - auxiliaram no processo de organização e de sistematização dos dados e em parte do processo analítico. Conforme o desenvolvimento da análise, entretanto, outra categorização se mostrou mais adequada como eixo principal de estruturação desta dissertação. Refere-se à questão central desta pesquisa, que é o debate sobre a racionalização e a industrialização da construção civil e o recorte dentro do subsetor de edificações.

A partir do debate teórico traçado por Villela (2007), compreendemos que o setor da construção civil passou por alguns períodos marcados por processos de racionalização da produção. Nesse sentido nos apropriamos do termo "Indústria da Construção Civil Subsetor de Edificações" (ICCSE), utilizado por Villela (2007), como um recorte analítico dentro do setor da construção civil como um todo. 0 planejamento e o controle das atividades produtivas se colocam como estratégias centrais no processo recente de racionalização dentro da ICCSE.

Identificamos alguns processos de racionalização a partir da observação de campo, e seguimos o trabalho analítico as categorias que consideramos mais pertinentes: o planejamento da produção; o controle do trabalho; os processos de execução racionalizados; e finalmente, as perspectivas futuras de racionalização da Empresa Nacional.

Após esta Introdução, a dissertação se inicia com o Capítulo 1 - Racionalização e Industrialização da Construção Civil, com uma abordagem conceitual sobre o setor da construção civil. Identificamos duas tendências de debate acerca da indústria da construção. Em termos gerais, a primeira delas se desenvolve sob o argumento de que o setor era excessivamente precário, pouquíssimo industrializado e, portanto, atrasado. Já a segunda tendência, norteada por estudos mais recentes, se construiu a partir da visão 
de que o setor da construção tem muitas particularidades e deve ser analisado através delas, sendo que as muitas estratégias de racionalização identificadas nas atividades da construção civil nas últimas décadas problematizam o estigma do atraso do setor.

Nos três capítulos seguintes, apresentaremos nossos "achados" de campo, que configuram o cerne desta dissertação. Neles estão as análises realizadas a partir da observação dos canteiros de obras, com ênfase nas estratégias que apontam para tendências de industrialização ou de racionalização da produção.

\section{No 'Capítulo 2 - Planejamento e organização da produção: o canteiro de obras'} tratamos das questões referentes ao planejamento e à organização do canteiro de obras, uma estratégia de grande importância do ponto de vista da racionalização da produção. É a parte inicial do processo construtivo, a preparação para todas as outras atividades da obra.

Seguindo para o 'Capítulo 3 - Regulamentação e controle do trabalho', nosso debate se volta aos modelos adotados pelas empresas construtoras pesquisadas acerca da organização e da regulamentação do trabalho. Um destaque deste capítulo é a discussão sobre a subempreitada e sua predominância nesse tipo de produção habitacional.

O 'Capítulo 4 - Da alvenaria estrutural às paredes de concreto' completa a discussão sobre o trabalho no canteiro de obras. Nos dois capítulos anteriores apresentamos questões relacionadas ao planejamento e ao controle do processo produtivo. Já no capítulo 4 chegamos ao processo de execução das obras analisadas em seus diferentes sistemas construtivos. 0 principal achado desse capítulo é o processo de expansão do sistema de paredes de concreto nos empreendimentos habitacionais de larga escala.

Finalmente, o 'Capítulo 5 - As perspectivas de inovação da Empresa Nacional' coloca a perspectiva da grande empresa construtora em relação à implementação de novas tecnologias em sua produção. Através do acesso a uma plataforma colaborativa na qual diversas empresas buscam soluções tecnológicas, foi possível tomar conhecimento de algumas iniciativas da Nacional. A empresa busca estratégias de racionalização que permitam o aumento da produtividade através de iniciativas de controle e gestão, o que demonstra que provavelmente o desenvolvimento da ICCSE esteja pautado mais pela organização e gestão dos processos produtivos - por vezes, com emprego de tecnologias inovadoras - e menos pela implementação da mecanização das atividades da construção. 


\section{CAPÍTULO 1}

\section{Racionalização e Industrialização na Construção Civil}

Com papel fundamental no cenário econômico e social do país, a construção civil sempre se destacou entre os setores produtivos. Marcada como grande absorvedora de mão de obra é considerada como um "termômetro" da economia. Historicamente, o setor da construção foi objeto de debates intensos e, muitas vezes, controversos. No Brasil, é possível considerar que se firmaram duas tendências de análise desenvolvidas principalmente a partir da década de 1970.

A primeira delas seguia um viés comparativo que colocava a indústria da construção em uma posição de atraso em relação a outros setores produtivos. De modo geral, os estudos que seguiam essa premissa criticavam principalmente as condições precárias de trabalho, a organização produtiva e a baixa mecanização do setor da construção. A baixa produtividade, os custos altos e os desperdícios conferiam ao setor o estigma do atraso. A solução proposta era justamente a industrialização da construção que deveria se basear em estratégias de organização, na produção em série e na mecanização (BRUNA, 1976). 
O autor entendia, portanto, que o desenvolvimento do setor da construção dependia de uma produção que se pautasse na racionalização do processo produtivo através da seriação e da padronização. Desse modo se colocava também a mecanização completa da produção como fator essencial para a modernização da ICCSE.

A industrialização está essencialmente associada aos conceitos de organização e produção em
série, os quais deverão ser entendidos, analisando de forma mais ampla as relações de produção
envolvidas e a mecanização dos meios de produção (BRUNA, p. 19, 1976).
Não é, portanto, só e unicamente o mecanismo que gera a indústria, mas uma decidida vontade
de repetir para a qual a máquina contribui como instrumento material e a organização como
método para executá-la (BRUNA, p.21, 1976). Contudo, o significado do termo "industrialização" não era consenso dentro da discussão no campo da construção civil. Alguns autores tinham o entendimento que a industrialização da ICCSE dependia da implementação de novas tecnologias construtivas, de soluções inovadoras, bastante sofisticadas e que fossem completamente préfabricadas. Ou seja, o resultado seria a edificação constituída por "sistemas industrializados", produzidos com elevado grau de mecanização (SABBATINI, 1989).

Tal concepção está diretamente relacionada à industrialização de outros setores produtivos, principalmente à indústria automobilística, cujo processo de desenvolvimento foi norteado pelas noções da "administração científica" que se tornaram uma espécie de conceitos clássicos sobre os processos de industrialização.

O caso da construção civil, todavia, é essencialmente distinto de outros setores produtivos, o que justamente levou a divergências em relação aos conceitos aplicados à ICCSE. Desse modo, se parte dos autores entendia que o desenvolvimento da ICCSE deveria seguir as premissas clássicas da administração científica, outra parcela defendia que o avanço nos processos de organização já correspondia, no caso da construção civil, à industrialização.

É justamente em torno dessa argumentação que se desenvolveram estudos que enquadramos nesta dissertação como a segunda tendência de debate. Tais estudos demonstram que não é possível sustentar a tese do atraso, uma vez que ao longo das últimas décadas a produção da construção civil passou por diversas iniciativas de racionalização, seja no aspecto gerencial, tecnológico ou financeiro. Essas análises identificam especificidades do setor da construção em relação a outros setores produtivos 
e defendem, portanto, que o desenvolvimento da ICCSE não seguiria exatamente as mesmas premissas que nortearam os avanços de outras indústrias.

A abordagem que enfoca a racionalização da construção se atenta, portanto, às iniciativas de modernização da gestão, da produção e do controle. De acordo com Sabbatini (1989, p. 67),

Racionalização construtiva é um processo composto pelo conjunto de todas as ações que tenham por objetivo otimizar o uso dos recursos materiais, humanos, organizacionais, energéticos, tecnológicos, temporais e financeiros disponíveis na construção em todas as suas fases.

O estudo da produção em larga escala da habitação demonstrou que o setor da construção civil se utilizou de diversas estratégias de racionalização nas últimas décadas, visando o aumento da produtividade e a redução de custos. Dessa maneira, os conceitos dessa segunda tendência de debate ajudaram na compreensão e na análise dos casos estudados. Antes de aprofundarmos as duas concepções apresentadas, buscaremos apresentar neste capítulo os números do setor no Brasil, de modo a demonstrar seu desempenho e importância frente a outros setores produtivos do país. Traremos também a discussão sobre o funcionamento do setor da construção civil, sua organização e as abordagens que serão utilizadas nesta dissertação.

\subsection{0 setor da construção civil nas pesquisas setoriais}

As atividades da construção civil abrangem um setor complexo, com engrenagens que funcionam de modo bastante específico em relação a outros setores produtivos. 0 setor é formado a partir da combinação dos mais variados subsetores, cada qual com modos de organização e gestão particulares. Como compreender, então, um setor que abrange atividades como a construção de edifícios habitacionais, grandes obras de infraestrutura, atividades de incorporação, serviços de instalações, etc.?

Existe uma heterogeneidade nas classificações sobre o setor da construção civil nas pesquisas que buscam caracterizar a estrutura e os números das atividades da construção. O Instituto Brasileiro de Geografia e Estatística (IBGE) regulamenta a Classificação Nacional de Atividades Econômicas (CNAE), que tem como objetivo principal, padronizar os códigos de identificação para abastecer os sistemas de 
informação utilizados como suporte às ações governamentais. De acordo com a $\operatorname{CNAE}^{25}$, a seção da construção é formada por três principais divisões: construção de edifícios; obras de infraestrutura; e serviços especializados para construção.

A "construção de edifícios" engloba as atividades de incorporação imobiliária e a construção de edifícios propriamente dita. Por "obras de infraestrutura", a CNAE entende basicamente obras de equipamentos públicos urbanos, transporte, energia e saneamento, além de obras industriais. Finalmente, no âmbito dos "serviços especializados para construção" são relacionadas as atividades-meio para a execução da construção civil, como obras de terraplanagem, instalações diversas, acabamento e fundações. Essa classificação contém apenas a denominação de cada atividade relacionada a um número correspondente à sua subclasse. Não existe uma descrição detalhada sobre cada tipo de atividade.

É importante ressaltar que a CNAE coloca os materiais da construção dentro da indústria de transformação. A seção das "indústrias de transformação" é subdivida em diversos grupos, portanto, a produção de cada tipo de material está classificada de acordo com suas respectivas especificidades. Desse modo, quando nos referirmos à seção da construção com base na CNAE não incorporamos a indústria de materiais de construção.

Além disso, existem duas organizações que tem papel importante na regulamentação das atividades: a Câmara Brasileira da Indústria da Construção (CBIC) e a Associação Brasileira da Indústria de Materiais de Construção (ABRAMAT). Através delas são divulgados pesquisas e estudos, informativos, projetos, e além disso, são entidades responsáveis por defender interesses do setor.

A CBIC utiliza uma categorização um pouco distinta daquela utilizada pela CNAE. E apresenta a "cadeia produtiva da construção" a partir de seis divisões: construção; indústria de materiais; comércio de materiais; serviços; máquinas e equipamentos; e outros fornecedores.

25 Informações em:

<http://subcomissaocnae.fazenda.pr.gov.br/modules/conteudo/conteudo.php?conteudo=1>. Acesso em: jun. 2017. 
De acordo com o banco de dados da CBIC, no ano de 2015, a cadeia produtiva da construção representou 8,32\% do PIB do país. A atividade da construção civil, por sua vez, representou 66,2\% do PIB da cadeia produtiva da construção, sendo que a indústria de materiais foi responsável por $11,2 \%$ e o comércio de materiais, $8,8 \%$ desse total. 0 restante fica por conta de outros fornecedores $(7,8 \%)$, serviços $(4,7 \%)$ e, finalmente, máquinas e equipamentos $(1,3 \%)$, conforme demonstra o gráfico ${ }^{26}$ a seguir:

Gráfico 2 - Composição da cadeia produtiva da construção por participação (\%) no PIB total da cadeia (2015)

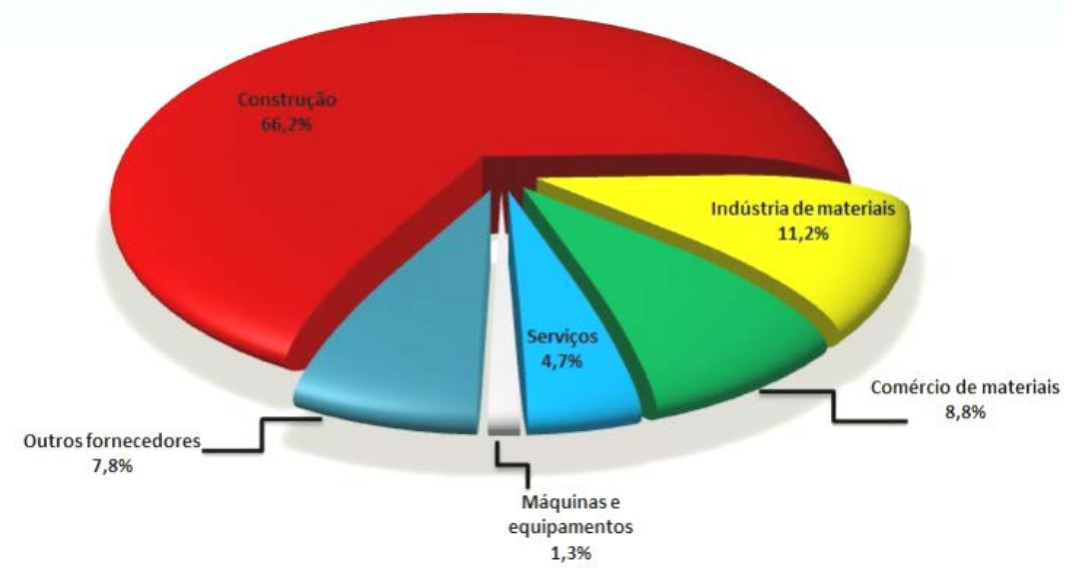

FONTE: ABRAMAT e FGV, Perfil da Indústria de Materiais de Construção, 2016.

De certo modo, a importância dada ao desempenho do setor da construção pode ser relacionada aos efeitos que impactam na economia do país. Nesse sentido, Gonçalves (2015) destaca o caráter pró-cíclico do setor da construção. De acordo com o autor, quando um setor acompanha as oscilações da economia, tem um caráter pró-cíclico, se tem um desempenho contrário aos movimentos da economia é anticíclico.

\footnotetext{
Como é regra dentre os segmentos que compõem a indústria de base, a construção civil tem, tipicamente, um caráter pró-cíclico. Vai muito bem quando a economia vai bem e muito mal quando a economia vai mal (GONÇALVES, p.1, 2015).
}

Desde 2007 o PIB da Construção Civil se expandia proporcionalmente ao PIB total do país - com exceção do ano de 2008 em que as variações dos PIBs foram equivalentes. No ano 
de 2010, houve crescimento bastante expressivo tanto do PIB da construção quanto do PIB total. Nos anos seguintes essa porcentagem de crescimento foi diminuindo, mas em 2014 os índices começam a ter variações mais significativas. Neste ano, o PIB total do país praticamente não cresceu e a construção civil teve variação negativa de -2,1\%. A situação continuou piorando, sendo que em 2015 e 2016, o PIB total teve variação de -3,8 e -3,6\% respectivamente e o PIB da Construção Civil amargou resultados ainda piores, -6,5 e $5,2 \%$.

Logo nas considerações iniciais do relatório do Perfil da Indústria de Materiais de Construção no Brasil (ABRAMAT e FGV, 2016), é comentado o baixíssimo desempenho da cadeia produtiva da construção em relação aos anos anteriores. Em 2014, o PIB do setor já havia caído consideravelmente se comparado a 2013. A ABRAMAT e FGV (2016) colocam o baixo desempenho do setor como um reflexo do cenário político e econômico bastante negativo dos últimos dois anos. A crise econômica se agravou neste período devido à alta da inflação e à elevação da taxa de juros sendo que a atividade imobiliária passou por uma intensa desaceleração. De fato, a retração não ocorreu apenas na cadeia da construção, mas em todas as esferas produtivas. Houve uma queda nos investimentos públicos que impactou toda a cadeia, devido à diminuição da demanda por materiais, equipamentos e serviços. 0 cenário apresentado era bastante pessimista também em relação ao ano seguinte, de 2016, conforme demonstra o gráfico a seguir.

Gráfico 3 - PIB Brasil x PIB Construção civil (\%) - 2004 a 2016

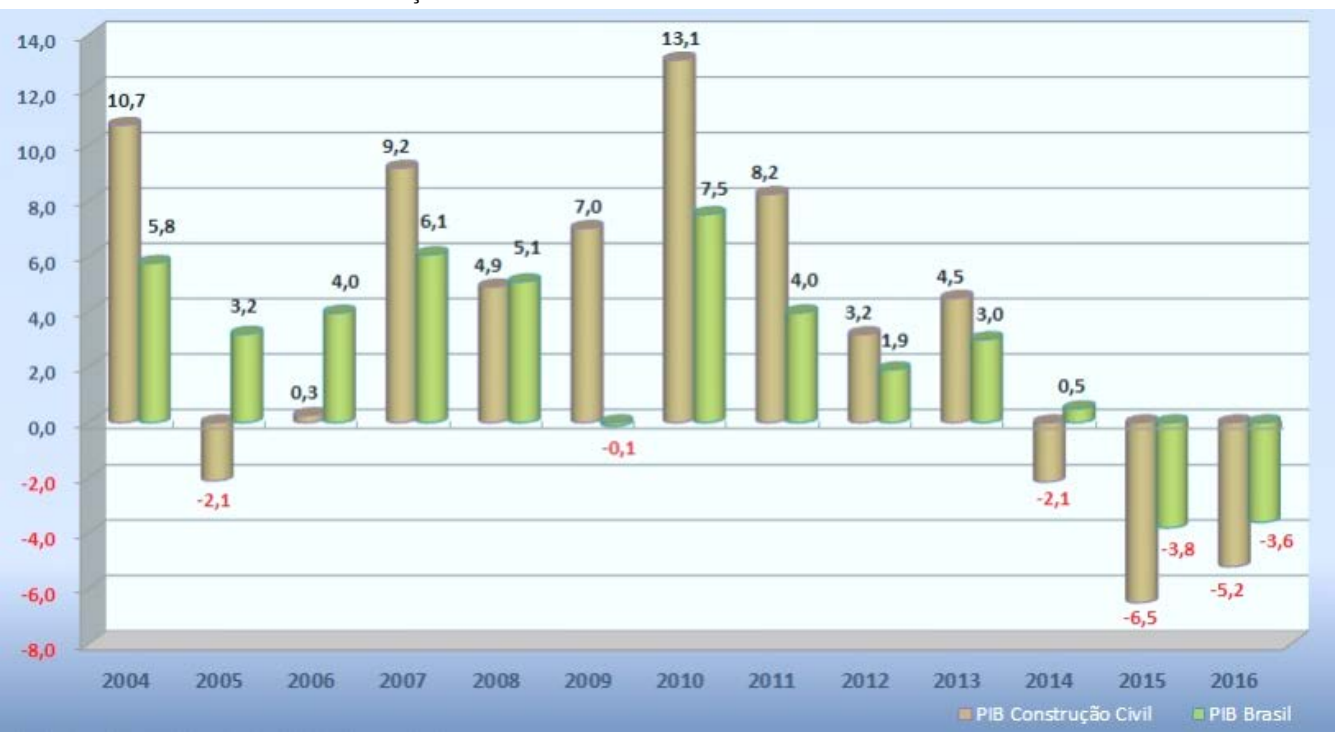

FONTE: CBIC, Banco de dados. <http://www.cbicdados.com.br/home/>. Acesso em: jun. 2017. 
Outra pesquisa de grande importância dentro do campo da construção civil é a Pesquisa Anual da Indústria da Construção (PAIC) ${ }^{27}$ realizada pelo IBGE, que também demonstrou a retração do setor a partir de 2014. Os resultados da PAIC de 2015 mostram números negativos, como diminuição das atividades de incorporação e saldo negativo de mão de obra. Essa pesquisa, realizada com base na CNAE, considera a construção de edifícios; as obras de infraestrutura; e os serviços especializados para construção - não relacionando, portanto, à indústria de materiais de construção.

A construção de edifícios é a que apresenta maior participação no setor. Apesar da retração geral do setor, a produção de edifícios teve um pequeno aumento em comparação com o desempenho de 2014, como demonstra o gráfico a seguir.

\section{Gráfico 4 - Participação percentual do valor das incorporações, obras e/ou serviços dentro do setor da} construção - 2014 e 2015

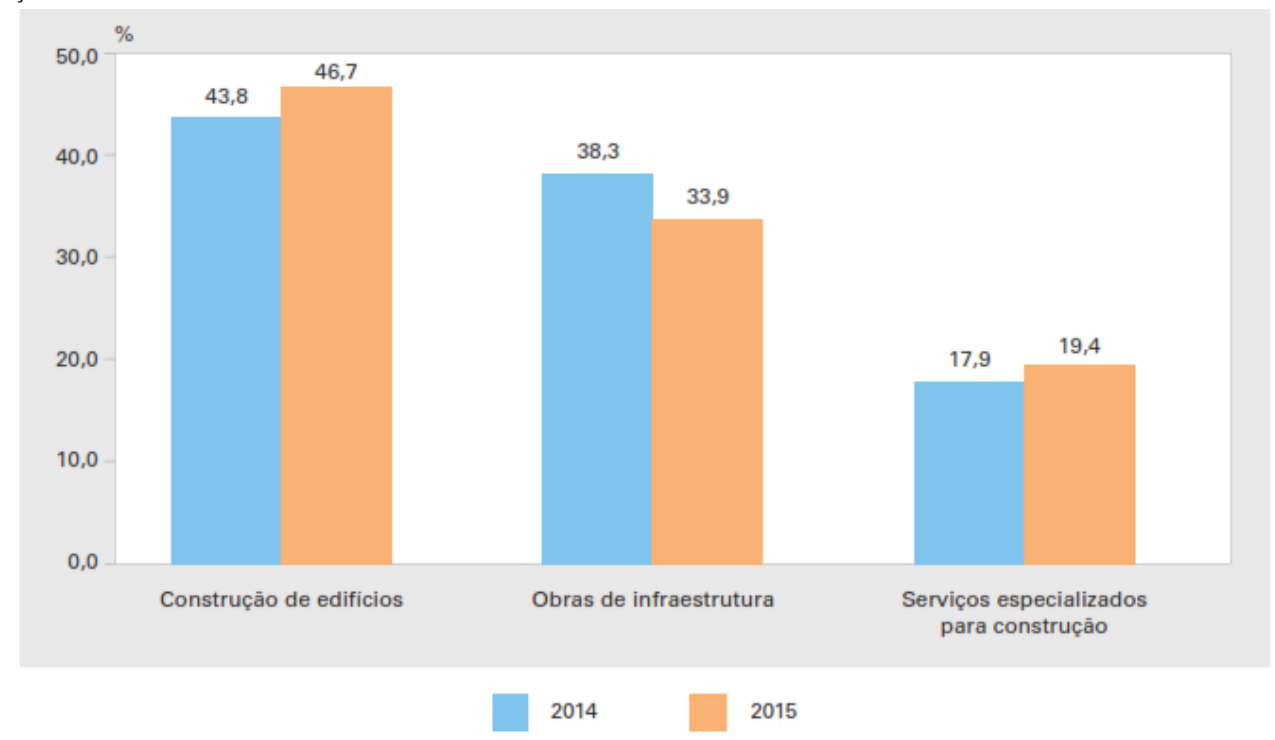

FONTE: IBGE 2015, p. 27.

De acordo com a PAIC de 2015, houve crescimento no número de empregos formais entre 2007 - quando o setor empregava cerca de 1,6 milhão de pessoas - e 2013 - quando chegou a empregar aproximadamente 3 milhões de trabalhadores. A partir daí esta 
estatística caiu para 2,9 milhões em 2014 e 2,4 milhões em 2015, como demonstra o gráfico abaixo.

Gráfico 5 - Emprego formal na construção civil (em milhões) 2007 a 2015

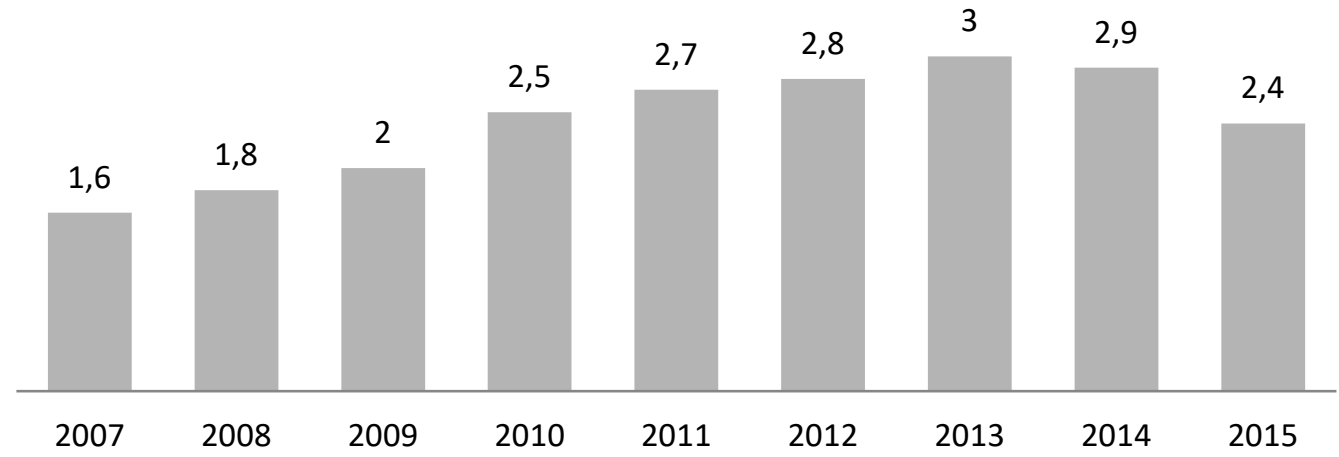

FONTE: Elaboração própria a partir de dados de IBGE (2015)

A repercussão do baixo desempenho da indústria da construção pós 2013 considerando-se ou não a produção de materiais de construção - foi expressiva. Reportagens enfatizando o pessimismo em relação à recuperação do setor e os efeitos da recessão da indústria da construção na economia do país foram frequentes. Recentemente, a construção civil foi responsável por fazer o índice geral do setor industrial recuar 0,5\% no segundo trimestre de 2017 em relação aos primeiros três meses do ano. Outros setores da economia tiveram ligeira melhora - crescimento de $1,4 \%$ no consumo, e de 0,6\% nos serviços. Especificamente a construção civil teve queda de $2,1 \%{ }^{28}$.

Dentro do setor da construção, a diminuição das vendas do varejo impactou a produção da indústria brasileira de materiais de construção, que já vinha perdendo espaço para as importações. Apesar da realidade bastante negativa da situação econômica do país e mais especificamente da cadeia da construção, é pertinente observar que a construção de edifícios é responsável por quase metade da produção total do setor em termos de valor.

28 CRISE na construção civil deixa indústria fora de recuperação. Folha de São Paulo. Set. 2017. Disponível em: <http://www1.folha.uol.com.br/mercado/2017/09/1915224-crise-na-construcao-civil-deixa-industria-fora-darecuperacao.shtml>. Acesso em: out. 2017. 
A construção de obras residenciais, por sua vez, representa quase 30\% da produção do setor da construção (IBGE, 2015). A produção de edificações, portanto, tem papel fundamental no setor da construção. É justamente no âmbito da construção de edifícios que se enquadra nosso objeto de estudo: a habitação.

\subsection{A construção civil no debate acadêmico}

Dentro da abordagem da pesquisa setorial o enfoque é o levantamento e a sistematização de estatísticas que permitam analisar o desempenho econômico do setor, traçar metas e discutir sua estrutura. Além disso, fornece dados para pesquisas e estudos mais aprofundados. No debate acadêmico, por outro lado, o entendimento das atividades da construção se coloca do ponto de vista qualitativo e procura analisar de modo mais crítico as engrenagens do setor, a partir das relações entre os subsetores - que não necessariamente correspondem às classificações das pesquisas setoriais. A discussão sobre o funcionamento e a organização das atividades da construção ainda é latente e cabe aqui situarmos a produção em escala da habitação neste debate.

O conjunto de atividades relacionadas à construção é tão vasto e diverso que os estudos tradicionalmente foram realizados a partir de subsetores, marcados por grandes distinções entre seus produtos construídos, as técnicas e as ferramentas empregadas. A compreensão global do setor, portanto, depende dos estudos parciais de cada subsetor (BARONE, 1999).

Na década de 1990, Martucci (1990) compreendia o setor da construção a partir de três grandes subsetores: a) Produção de Componentes e Materiais de Construção; b) Máquinas, Equipamentos, Ferramentas e Instrumentos; c) Projeto, Produção e Montagem. Os subsetores de materiais (a) e de equipamentos (b) sustentam a produção final da atividade da construção. 0 setor (c) é o que trata efetivamente do produto final, a edificação, por exemplo. Os três subsetores nutrem uma relação de interdependência. É preciso que sejam produzidos ou beneficiados materiais e insumos que servirão como matéria prima para o produto final e, do mesmo modo, é necessário que sejam fabricados equipamentos que auxiliem na execução deste produto.

Em seus estudos, Martucci (1990) identifica justamente essa relação de interdependência entre os subsetores, mas ressalta que cada um deles possui certa autonomia. As decisões 
políticas e a gestão de cada subsetor se constroem de forma independente. Isso significa que não necessariamente a totalidade do setor da construção terá igual desenvolvimento. Nesse sentido, o autor acreditava que os subsetores responsáveis pelos meios - materiais e equipamentos - tinham um caráter mais industrializado do que o subsetor de projeto, produção e montagem, aquele responsável pelo produto final.

Seguindo uma definição próxima de Martucci (1990), Castro (1999) ressalta a distinção entre o subsetor responsável pela construção em si e o subsetor que produz os componentes. Em seu ponto de vista, a indústria de componentes tinha um papel fundamental no desenvolvimento tecnológico do setor da construção como um todo. 0 autor tinha a hipótese de que as mudanças de tecnologias partiam justamente da mudança dos componentes construtivos. Por esse motivo, se fazia relevante dividir as análises entre as atividades da construção propriamente dita e a produção dos componentes.

De acordo com Castro (1999), existe uma interdependência entres os subsetores, uma vez que o projeto e a produção das edificações dependem necessariamente da indústria dos componentes. Uma crítica do autor era que os projetistas dos edifícios não se envolviam também nos projetos dos elementos construtivos, o que dificultava a modernização da construção resultando em uma disparidade entre o desenvolvimento dos dois subsetores.

[...] a construção é um setor usuário da indústria de insumos diversificados que compõem a edificação. Tanto uma como a outra têm relações quanto à origem e finalidade dos seus produtos, pulverizados de tal forma que parecem à primeira vista ser naturais e permanentes. No entanto, o setor de produtos componentes tem dinâmica própria face ao setor da indústria da construção. (CASTRO, p. 10, 1999)

Gitahy e Pereira (2002) entendem também que existe uma distinção entre a produção de materiais de construção e a construção propriamente dita. Dentro da chave da 'construção', os autores colocam a 'construção pesada' - que abarca todas as atividades voltadas à produção da infraestrutura urbana - e a 'construção imobiliária' - que se refere às edificações sejam elas habitacionais, comerciais ou industriais. Os autores vão chamar o conjunto total de atividades e segmentos que englobam a produção do espaço 
construído de "complexo da construção"29. Essas atividades se referem ao comércio, à produção, aos serviços e ao financiamento das operações, e são fortemente interdependentes, daí a utilização do termo 'complexo'.

Seguindo a mesma abordagem, Lovera (2014) vai trabalhar com o conceito de 'cadeia produtiva da construção'. A 'construção' é composta por atividades técnico-construtivas e por atividades econômicas, sendo que o objeto final é o que ele chama de 'meio ambiente construído'. O autor entende o 'ambiente construído' como o suporte físico para a reprodução da sociedade, tanto dentro da produção de edificações quanto na de obras civis.

O conceito 'ambiente construído' já foi abordado anteriormente por Harvey (2006) para abarcar o conjunto completo de objetos que compõem o espaço, sobre os quais se reproduzem a sociedade, e que se convertem na forma mercadoria dentro das relações capitalistas.

0 ambiente construído compreende toda uma série de elementos diversos: fábricas, represas, escritórios, lojas, armazéns, rodovias, ferrovias, docas, usinas hidrelétricas, sistema de suprimento de água e tratamento de esgoto, escolas, hospitais, parques, cinemas, restaurantes - a lista é infinita (HARVEY, 1982, p. 357).

A cadeia produtiva da construção ${ }^{30}$ incorpora, portanto, diversos ramos e operações que envolvem atividades relacionadas à produção de materiais, insumos e componentes, bem como de máquinas e equipamentos, além de gerenciamento, comércio e atividades financeiras do setor (LOVERA, 2014).

Os estudos demonstram, portanto, que o setor da construção é formado por um conjunto de atividades distintas que se inter-relacionam. Para Lovera (2014), se trata da 'cadeia

\footnotetext{
${ }^{29}$ Gitahy e Pereira (2002) vão se utilizar do termo "complexo da construção" para caracterizar a produção da construção civil dos anos 1930 em São Paulo. Entretanto, esta conceituação pode auxiliar também na compreensão atual do setor da construção. De acordo com os autores, “na denominação 'complexo', pretende-se deixar clara a forte interdependência das várias atividades. Tanto a suficiência técnica de cada segmento quanto a autonomia de cada um deles são relativizadas. Essa relativização da separação das diversas atividades da construção, como indústrias especializadas, isoladas em esferas setoriais ou subsetoriais, constitui o que chamamos aqui de "complexo da construção'” (GITAHY \& PEREIRA, p. 16, 2002).

30 Lovera (2011) cita outras denominações como 'macrossetor da construção, sistema setorial da construção, circuito da construção, setor da construção', etc. como conceitos equivalentes à 'cadeia produtiva da construção'. A nomenclatura se refere apenas a um recurso metodológico que permite analisar diversas atividades que convergem na construção propriamente dita.
} 
produtiva da construção' e para Gitahy e Pereira (2002), do 'complexo da construção'. Para nos referirmos ao conjunto completo de atividades que resultam no meio ambiente construído, utilizaremos o termo 'setor da construção'. Trata-se de um conceito abrangente que não é o objeto principal deste estudo, por este motivo, optamos por um termo direto e comumente utilizado tanto nas bibliografias quanto em documentos técnicos.

Uma vez compreendida a abrangência do setor da construção, se faz necessário um primeiro recorte. A separação entre a produção de obras civis e a produção de edificações é consenso entre os estudos. Seguiremos, portanto, a partir dessa primeira distinção, enquadrando este estudo no subsetor de edificações. 0 termo "Indústria da Construção Civil Subsetor de Edificações" (ICCSE) foi adotado por Villela (2007) e estamos nos apropriando, portanto, da nomenclatura utilizada pelo autor.

A partir dessa análise macro do setor da construção civil, situamos a produção em larga escala da habitação justamente dentro da ICCSE. A questão que se coloca neste momento é como se organiza internamente esse campo das atividades da construção. Referimosnos mais especificamente ao processo de trabalho e sua organização. Conforme colocamos já na abertura deste capítulo, identificamos duas tendências nesse debate. A primeira delas defendia a industrialização do setor e a segunda que compreendia as atividades da construção através de conceitos relacionados à racionalização. Essas duas vertentes vão nortear, portanto, os dois próximos itens deste capítulo.

\subsection{Industrialização}

O setor da construção tem papel bastante relevante no cenário produtivo no país, conforme demonstramos nos itens anteriores. Durante as últimas décadas, diversos estudos tiveram, portanto, o processo produtivo da ICCSE como questão central, sendo que parte dos autores - que aqui enquadramos na primeira tendência de debate enxergava o setor da construção sob o estigma do atraso. Tal análise baseava-se nas flagrantes situações de precariedade da ICCSE, principalmente a partir da década de 1970. 
Enquanto os demais setores industriais se desenvolviam a partir de preceitos clássicos ${ }^{31}$ da administração científica, as atividades da construção eram marcadas pela baixa organização da produção, pelo trabalho precarizado, por altos custos e pelo desperdício. É nesse contexto que se constrói o argumento da necessidade de industrialização plena da ICCSE.

\title{
Organização do trabalho
}

No modo de produção capitalista o desenvolvimento das forças produtivas ocorreu tanto no aspecto mecânico quanto no campo da organização do trabalho. A incorporação das máquinas significou importantes avanços técnicos nos processos produtivos. Já a organização do trabalho se coloca de modo a atender duas necessidades primordiais. A primeira delas, de ordem política, é manter a subordinação dos trabalhadores ao capital através de mecanismos de controle e vigilância, do parcelamento do trabalho e da mecanização. A segunda, de cunho econômico, tem a ver com o aumento da produtividade (MOURA, 2011).

\begin{abstract}
A administração científica, denominada também como gerência do trabalho ou organização do trabalho, teve papel fundamental na transformação do processo produtivo e na adaptação do homem à máquina na indústria, principalmente ao utilizar as virtudes da ciência e da técnica para tornar menos evidentes os processos de coerção (MOURA, 2011, p. 32).
\end{abstract}

As ideias de Taylor $^{32}$ e Ford ${ }^{33}$ conformam o cerne da "teoria da moderna gerência do trabalho", que colocava a ciência como principal estratégia para o aumento da produtividade e do controle de trabalho. 0 contexto político e econômico norte-

\footnotetext{
${ }^{31}$ Por preceitos clássicos da industrialização entendemos o processo de desenvolvimento dos setores produtivos norteados pelas noções da Administração Científica. Ou seja, é marcado pela racionalização do processo de trabalho - com ênfase para a questão do controle do trabalho e aumento da produtividade -, além da mecanização completa da produção. Em relação à indústria da construção civil, podemos destacar a referência de BRUNA (1976).

32 Em termos gerais, a concepção taylorista de "Administração Científica" do trabalho seguia três princípios. Todo trabalho deveria ser cientificamente analisado e a partir daí controlado pela gerência; os trabalhadores também deveriam ser selecionados criteriosamente a depender da função que ocupariam; finalmente, toda atividade deveria ser cuidadosamente planejada. Sinteticamente esta era a base da 'Administração Científica' (FLEURY \& VARGAS, 1983).

${ }^{33}$ A regra geral do fordismo era que tudo deveria ser organizado de modo a tornar o processo produtivo o mais eficiente possível. Isso incluía estratégias como parcelamento e controle rigoroso do trabalho e introdução de máquinas e equipamentos que otimizassem a produção (FLEURY \& VARGAS, 1983).
} 
americano da época era marcado pela consolidação do capitalismo monopolista, marcado pelo crescimento das empresas e pela fusão do capital financeiro com o capital industrial. Esse cenário colaborou para o desenvolvimento e disseminação dos preceitos da administração científica (MOURA, 2011).

De acordo com Fleury e Vargas (1983), a administração científica norteou o desenvolvimento de "técnicas de gestão e organização do trabalho e da produção". Já na década de 1980, os autores entendiam que os princípios tayloristas continuavam vigentes, apesar da superação de alguns métodos e técnicas propostas por Taylor. 0 cenário político e econômico do país, entretanto, influenciavam diretamente no modo como essas "ideologias" - por exemplo, o taylorismo - eram difundidas no setor empresarial. Fleury e Vargas (1983) ressaltam ainda que a aplicação do taylorismo não foi homogênea entre os diversos setores industriais e citam como exceção a construção civil.

\begin{abstract}
No entanto, isto não quer dizer que o taylorismo seja aplicável indiferentemente a qualquer tipo de indústria. Existem aquelas em que as características materiais do processo produtivo ou o porte da empresa dificultam sua difusão. Tal é o caso das indústrias de processos e da construção civil ou das empresas que têm produtos muito diversificados (FLEURY e VARGAS, 1983, p. 18).
\end{abstract}

De modo geral, as indústrias como a automobilística, mecânica, metalúrgica, siderúrgica, etc., aplicaram estratégias tayloristas e fordistas em sua produção, e foram marcadas pela racionalização e mecanização dos processos. Enquanto isso, a ICCSE permanecia supostamente em um patamar anterior, se apoiando no artesanato e na manufatura, contando com práticas de improviso e de empirismo. É nesse sentido que parte dos estudos entendia a construção civil sob a ótica do atraso em relação aos demais setores produtivos ${ }^{34}$. Como veremos adiante, diversos autores denunciavam situações precárias

\footnotetext{
34 No livro "Organização do Trabalho: uma abordagem interdisciplinar e sete estudos sobre a realidade brasileira", Fleury e Vargas (1983) visitam a obra de Taylor e Ford para discutir questões sobre eficiência e produtividade, metodologia de pesquisa e, finalmente, estudos de caso. Os setores abordados pelos autores são: indústrias mecânicas, indústria metalúrgica, indústria siderúrgica, indústria do vestuário, bancos, construção habitacional e indústria da programação. Em suma, a ICCSE aparecia lado a lado com outros setores industriais do país dentro de um estudo que buscava discutir as particularidades e as engrenagens organizacionais e produtivas inseridas em cada setor.
} 
nas atividades da construção, como péssimas condições de trabalho, baixo nível de organização da produção, alto custo e desperdício. A industrialização plena da construção aparecia, portanto, como uma solução para o desenvolvimento do setor, inclusive em relação à produção da habitação.

\section{A [não] industrialização da construção civil e a noção do atraso}

A partir de um viés marxista, Maricato (1984) desenvolve algumas noções pertinentes acerca da passagem do processo de trabalho baseado no artesanato até a consolidação da grande indústria. Dentro do modo de produção capitalista, a divisão do trabalho é a base da produção industrial. As etapas são executadas em série, simultânea e sucessivamente. É uma engrenagem que funciona a partir da cooperação entre trabalhadores e, por vezes, entre trabalhadores e máquinas. Essas atividades devem ser sempre coordenadas e gerenciadas e, além disso, devem se utilizar das premissas da administração científica. Os trabalhadores da indústria não têm controle sobre a totalidade do processo produtivo. Nesse ponto se coloca a principal diferença desse modelo produtivo em relação ao artesanato. 0 artesão era o responsável pela produção de determinado produto, da concepção ao acabamento. Como consequência, cada produto era único, resultado do saber e da habilidade acumulados do artesão. 0 produto industrial, entretanto, pressupõe que os objetos sejam absolutamente iguais entre si (MARICATO, 1984).

A manufatura, por sua vez, pressupõe o saber do trabalhador, depende de suas habilidades, sendo que o ritmo da produção é dado pelo próprio trabalhador. Já o trabalhador industrial, ao contrário, está submetido à maquinaria - que inclusive dita a produtividade. $\mathrm{O}$ avanço do processo industrial pressupõe o máximo de automação e, consequentemente o mínimo de intervenção do trabalhador ${ }^{35}$. A implementação da maquinaria, ou seja, a "modernização do processo produtivo" tem como consequência

\footnotetext{
35 Nas palavras de Marx (2002: 482): "Na manufatura e no artesanato, o trabalhador se serve da ferramenta; na fábrica, serve à máquina. Naqueles, procede dele o movimento do instrumental de trabalho; nesta, ele tem de acompanhar o movimento do instrumental. Na manufatura, os trabalhadores são membros de um mecanismo vivo. Na fábrica, eles se tornam complementos vivos de um mecanismo morto que existe independente deles".
} 
esperada a diminuição do número de trabalhadores, uma vez que a mecanização pressupõe o aumento da produtividade ${ }^{36}$. (MARICATO, 1984).

Essa perda progressiva da individualização do trabalhador e a crescente desvalorização das habilidades de cada um configuram a chamada subsunção formal e a subsunção real. A subsunção formal está presente na manufatura e pressupõe um pequeno domínio nas mãos do trabalhador. Ele perde sua individualização, mas ainda detém certo controle sobre seu trabalho. A subsunção real aparece na indústria, com a maquinaria que esgota qualquer domínio do trabalho pelo sujeito. 0 trabalhador aparece apenas como um coadjuvante, a máquina se torna o verdadeiro produtor.

A manufatura orgânica está muito presente nos canteiros de obras - Sérgio Ferro, (2006 [1976]) vai chamá-la de manufatura serial, que se realiza etapa após etapa, em série. Em meados dos anos 2000, Ferro (2006 [2003]) vai revisitar seus estudos iniciais da década de 1970 no texto "Sobre o canteiro e o desenho", no qual novamente coloca a construção como uma produção marcada pela organização manufatureira. No canteiro de obras dos anos 1970, as equipes eram numerosas, separadas, especializadas e verticalizadas. As máquinas somente auxiliavam em trabalhos pesados. 0 trabalhador era o elemento imprescindível no trabalho da construção civil, conformando a chamada manufatura serial. Essa dependência em relação ao trabalho manual nos canteiros daquela época colocava o Brasil na esfera dos países subdesenvolvidos, com uma forma de produção précapitalista (FERRO, 2006 [2003]).

Para Ferro (2006 [2003]), a manufatura é obstinada: não se transformará em indústria na construção civil. Isso porque a construção civil é um dos grandes nichos de extração de mais valia ${ }^{37}$. Considerando-se que o trabalho é a única forma de produção de valor, a

\footnotetext{
36 Maricato (1984) ressalta que caso o custo da mão de obra para alcançar determinada produtividade for mais baixo que o custo da maquinaria, tal fator torna-se um impeditivo para a mecanização. “Daí porque a mão de obra barata atrasaria a incorporação da maquinaria" (MARICATO, 1984, p.28).

37 Mais-valia relativa "é a quantidade de trabalho que faz parte da jornada de trabalho não paga ao trabalhador, e que resulta da redução do tempo do trabalho necessário (valor apropriado pelo trabalhador) em contrapartida ao aumento do trabalho excedente (valor apropriado pelo capitalista). Mais-valia absoluta é a que se obtém através do prolongamento da jornada de trabalho." (MARICATO, 1984, p. 26).
} 
colocação de Ferro (2006 [2003]) sobre a obstinação da manufatura nos canteiros de obras é por conta do papel que a construção detém no processo de reprodução do capital. A produção no canteiro não é para uso próprio, a força de trabalho é apenas uma mercadoria. Por este motivo que nos anos 2000, muito tempo depois de suas primeiras análises, Ferro (2006 [2003]) continua enquadrando o modo de produção dos canteiros de obra dentro da manufatura. Segundo o autor, a construção não pode ser considerada como artesanato, dada a divisão avançada do trabalho. Também não se utiliza de processos automáticos para realizar suas operações, pois a força de trabalho se mantém essencial dentro do canteiro. Tampouco os produtos industriais frequentemente utilizados na ICCSE podem, em sua visão, colocar a produção da construção no mesmo patamar da indústria (FERRO, 2006 [2003]).

Assim como Ferro (2006 [1976]), Maricato (1984) também enquadra a produção da ICCSE dentro da esfera da manufatura, caracterizada pelo trabalho com aspectos artesanais e equipes setorizadas. Mas, em sua visão, essa parcelização do trabalho se dava de forma exacerbada dentro do canteiro de obras. Em uma descrição de um canteiro de obras, Maricato (1984) apresenta a produção da ICCSE enfatizando retrabalhos, desperdícios, falta de organização dos processos e grande rotatividade de trabalhadores.

Como em qualquer manufatura, no canteiro, o trabalho que guarda aspectos artesanais vem combinado a uma divisão entre equipes e trabalhadores. Na indústria da construção, entretanto, a separação, a fragmentação, entre as equipes é exacerbada, ferindo a própria eficácia do processo de trabalho. As equipes se sucedem destruindo parte do trabalho da anterior. Eletricistas e encanadores quebram as paredes para fazer passar a fiação, os marceneiros ampliam as aberturas para colocação das esquadrias.

Se estes forem menores que as aberturas, há a necessidade do pedreiro voltar ao local, após o trabalho do marceneiro, para vedar os buracos resultantes deste descompasso. As empresas que se utilizam de processos mais avançados já superaram parte dessa superposição de função, o que não significa, entretanto, que os avanços estejam generalizados no setor. 0 resultado é um grande volume de entulho no canteiro. Além do desperdício em materiais e horas de trabalho, há necessidade ainda de empenhar trabalho na limpeza do canteiro. 0 grande volume de entulho retirado de um canteiro exige sempre providências em relação ao transporte, bem como em relação ao seu destino.

A cada final de obra, a unidade de produção é desmontada, as equipes desfeitas, a maior parte dos trabalhadores é despedida ou na melhor das hipóteses passa a trabalhar em outra obra (outro projeto, outro terreno, outras características).

A produção dos materiais utilizados na indústria da construção provém de indústrias, algumas das quais avançadas, mas a construção propriamente dita está longe de ser industrializada mesmo nos países capitalistas centrais. Nestes encontramos uma manufatura heterogênea que 
se utiliza de pré-fabricados. Nos países capitalistas não desenvolvidos, encontramos (com exceção de alguns casos), a manufatura serial, voltada mais para o trabalho no local. (MARICATO, 1984, p. 32-34).

Além da precariedade do processo de construção em si, as condições a que estavam submetidos os trabalhadores da ICCSE eram também extremamente danosas. Jornadas extensas de trabalho, acidentes, baixos salários, pouco amparo legal. Maricato (1984) dedica um capítulo de sua tese de doutorado - o qual ela chama "Força de trabalho na construção civil: um massacre dissimulado" - para denunciar os abusos sofridos pelos trabalhadores da construção nos canteiros de obras.

Os estudos que analisaram a ICCSE identificaram uma série de questões que, em conjunto, explicariam as dificuldades do setor em se industrializar. Seriam por exemplo: a grande variabilidade de tarefas do setor; o caráter parcial da padronização; as irregularidades das tarefas no decorrer do tempo; o papel central da terra; grande tempo de rotatividade do capital. Esses fatores conferem à ICCSE um caráter peculiar, que a distingue de outras indústrias. Muitos deles inclusive são externos à dinâmica produtiva propriamente dita, como por exemplo, o tempo prolongado de rotação do capital.

Um dos argumentos dessa linha é que o processo produtivo, ou a construção propriamente dita, tem menor importância na obtenção dos lucros frente a outros desdobramentos das atividades da ICCSE como, por exemplo, as atividades imobiliárias. Ou seja, a escolha correta do terreno traria melhores retornos financeiros do que a industrialização dos processos produtivos. De acordo com Maricato (1986) a sobreposição do imobiliário sobre o produtivo era consenso entre os estudos ${ }^{38}$ da época e, portanto, um dos motivos para o 'atraso' da ICCSE.

[...] há praticamente um consenso entre os estudiosos de que o lucro imobiliário está acima do lucro médio, que se verifica em outros setores industriais e que a apropriação desse sobrelucro ou superlucro é feita pelos agentes "improdutivos": incorporador imobiliário, proprietário da terra e capital financeiro. Esses fatores, portanto, determinariam (ou influenciariam) o atraso no processo de trabalho (MARICATO, 1986, p.116).

${ }^{38}$ Entre os estudos, Maricato (1986) cita Vargas (1981); Pereira (1982); Sarli (1981); Topalov (data?), Forti (1979); Ribeiro (1982). 
A autora entende que tais fatores - a questão imobiliária e o longo período de rotatividade do capital - influenciavam o baixo desenvolvimento do setor. Entretanto, os problemas existentes dentro do processo produtivo eram graves demais para terem segunda importância nessa discussão. Maricato (1986) coloca os baixos salários, as extensões nas jornadas de trabalho, acidentes, a grande rotatividade, a desorganização e o desperdício, além de um "impressionante atraso tecnológico" como aspectos fundamentais e que requisitavam, portanto, soluções. Entretanto, o debate ainda estava aberto, não havia ainda conclusões definitivas para a superação do atraso do setor (MARICATO, 1986).

\begin{abstract}
Essa precária organização da produção e incipiente base técnica refletem-se nos desencontros das equipes de trabalho e nos desperdícios de materiais. No método tradicional, cada etapa interfere nas subsequentes. Os erros da concretagem ou deformações provocadas nas fôrmas de madeira prejudicam os alinhamentos da alvenaria. A alvenaria é feita independente das instalações elétricas e hidráulicas, que, por sua vez, exigirão destruir parte da alvenaria ou efetuar orifícios nas fôrmas de concreto para embutir as tubulações. No final o emboço e o contrapiso serão utilizados para corrigir as deformações anteriores, com gastos adicionais de material. Além disso, cada uma dessas operações, por si, desperdiça material devido aos métodos empregados. 0 resultado final é a perda do trabalho executado e um enorme volume de entulho, que exige trabalho adicional para ser coletado e transportado (VARGAS, 1981, p. 28).
\end{abstract}

A descrição de Vargas (1981) é bastante semelhante à descrição de Maricato (1984) transcrita anteriormente - sobre o processo produtivo no canteiro de obras. Ambos os autores identificam situações precárias e extremas, que resultavam em desperdício de materiais e de trabalho e alto custo de produção.

\footnotetext{
A base técnica e organizacional da construção habitacional tem suscitado intenso debate nos meios intelectual, governamental e empresarial. Essa base técnica é, geralmente, rudimentar, o trabalho precariamente organizado e o controle e nivel de produtividade baixos. As operações, os métodos e os produtos não são padronizados, havendo um esforço renovado para cada obra. Essa situação confere à habitação o status de "artesanato de luxo", revelando o atraso relativo da construção habitacional em relação aos demais setores industriais. Existem verdadeiras barreiras para industrializá-la e determinantes que entorpecem a evolução técnica e organizacional do setor (VARGAS, 1981, p. 27).
}

Vargas (1981) inicia seu artigo "Construção habitacional: um artesanato de luxo" justamente explicitando a dificuldade da ICCSE, particularmente a produção da habitação, em se industrializar. A primeira consideração feita pelo autor refere-se ao caráter artesanal da produção habitacional. 0 autor se utiliza da ideia de artesanato no sentido da produção manual da construção, não exatamente dentro da conceituação clássica que define o artesão como aquele que detém todo o processo produtivo. A consideração 
principal é que pouco se utilizavam máquinas e equipamentos dentro das obras (VARGAS, 1981).

Essas características criam um problema de controle de mão de obra, pois o ritmo e a sequência de trabalho não são dados por um complexo de máquinas, nem o suprimento de matéria-prima e componentes é feito em cadeia continuamente, como ocorre com a produção em série de automóveis (VARGAS, 1981, p. 27, grifo próprio).

Observamos no trecho acima a comparação entre a produção da ICCSE com a produção da indústria automobilística. A análise de Vargas (1981) se apoia no funcionamento de outra indústria, esta mecanizada, com ritmo de produção previamente estabelecido, controle rigoroso do trabalho, produção seriada - a indústria clássica. A leitura do autor é que a construção civil não se enquadra nos preceitos dessa indústria clássica e, aí, se coloca a problemática do atraso.

A solução encontrada pelas empresas construtoras para superar os problemas do controle de mão de obra foi o regime da subcontratação. Geralmente, o trabalho da subempreitada é pago por produtividade e essa característica por si própria representa uma estratégia de controle do trabalho - que evidentemente fica a cargo do subempreiteiro e não da empresa construtora. Vargas (1981) ressalta que a subempreitada melhora a produtividade dentro da obra, entretanto, aprofunda a precarização do trabalho e desestimula a implementação de inovações tecnológicas. Tudo isso colaborava em acentuar o caráter "arcaico" da produção habitacional (VARGAS, 1981).

Vargas (1992) afirma que a 'indústria' da construção civil sempre foi considerada um setor atrasado, mas que apesar disso, apresentou crescimento e desenvolvimento desde a década de 1940. O surgimento da figura do "peão" colaborou para intensificação das atividades da construção civil. Era o trabalhador rural que estava fugindo das péssimas condições de trabalho no campo e que começava a trabalhar na construção civil, sem a aparente necessidade de se fixar em alguma cidade ou em alguma empresa. Daí a formação de mão de obra abundante, de trabalhadores com pouca escolaridade, que passavam rapidamente de um canteiro para outro e que geralmente eram especializados em determinada função. As empresas construtoras, por sua vez, viram no Estado um cliente capaz de aumentar suas áreas de atuação e seus lucros. Desse modo, a construção civil permanecia no patamar da produção não industrializada, sem inovações tecnológicas, seja em equipamentos ou materiais (VARGAS, 1992). 


\section{A industrialização da ICCSE}

Como já apontado, muitos autores entendiam que o avanço do modelo industrial na produção da ICCSE era bastante desejável e que o 'atraso' do subsetor estava diretamente relacionado ao seu baixo grau de industrialização. Em seus estudos, Bruna (1976) afirmava que a construção tradicional era essencialmente artesanal, constituída por um conjunto de atividades artesanais que deveriam ser realizadas por profissionais especializados. 0 autor ressalta, entretanto, que na prática a mão de obra era composta em grande parte por trabalhadores não qualificados, o que, por consequência, significava ineficiência, desperdícios e alto custo. A solução deveria se basear mais na racionalização e na mecanização - ou seja, a industrialização ${ }^{39}$ - da produção do que na ampliação da formação dos operários, uma vez que este seria um processo lento e caro.

"A racionalização e mecanização dos métodos construtivos parece ser o caminho para integrar extensos contingentes de mão de obra não qualificada; a máquina pode ser operada por trabalhadores cujo treinamento é muito curto, e a economia de escala pela produção em massa é o único meio para baratear o custo final da habitação" (BRUNA, 1976, p. 14).

A situação do desenvolvimento do Brasil na época, todavia, dificultava a viabilização da implantação da industrialização na construção. Existia no país uma massa de trabalhadores migrantes do campo pouco exigente em relação a salários e condições de trabalho, o que minimizava o investimento rumo à industrialização do setor da construção. Mas, o baixo custo da mão de obra não representava necessariamente um baixo preço da edificação. Grande parte da população não tinha acesso à moradia digna, uma vez que os preços altos eram uma barreira intransponível (BRUNA, 1976).

Bruna (1976) discute a questão da industrialização da construção justamente em meio a um período de intensa e crescente urbanização no país. Entre 1940 e 1980 as populações das cidades brasileiras cresceram consideravelmente - de 31,2\% na década de 1940 para $66,7 \%$ na década de 1980. As consequências deste processo acelerado de urbanização foram também intensas e de maneira geral, negativas. As cidades não tinham

\footnotetext{
39 Bruna (1976) entende que o conjunto de ações de racionalização mais mecanização da produção tem como resultado a industrialização. Esta equação foi extraída por Bruna (1976) de Blachère, G. que a formulou tomando como base o desenvolvimento da industrialização na França. Bruna (1976) acreditava que o desenvolvimento da construção de habitações no Brasil seguiria esta lógica: de racionalização e de mecanização.
} 
infraestrutura suficiente para absorver de forma digna e confortável toda a parcela da população migrante o que causou sérios problemas sociais. 0 autor aponta o déficit habitacional como o mais grave dentre esses problemas.

Na década de 1970 a estimativa era de que o déficit habitacional estava na ordem de oito milhões de unidades. A ICCSE, por sua vez, não tinha estrutura para fomentar uma produção habitacional dessa grandeza e, além disso, existia a questão da infraestrutura urbana que deveria servir às unidades que fossem construídas. A problemática da moradia era, portanto, preocupante. Fazia-se necessário o aumento da produtividade do setor e o meio para alcançar este objetivo, na visão de Bruna (1976), era industrializar a construção.

A industrialização das atividades da construção deveria passar também pela racionalização dos materiais de construção, seguindo padrões e normas. Além disso, para Bruna (1976) era essencial que fosse obrigatório utilizar apenas materiais normatizados e confiáveis, o que seria evidentemente uma ação de longo prazo.

A evolução das ferramentas e das máquinas, ou seja, o avanço da mecanização foi o que iniciou o processo de industrialização. Num primeiro momento, as máquinas reproduzem a partir da energia - que não a do homem ou a natural localizada - as ações antes realizadas de modo artesanal. Depois, a máquina passou a ter a capacidade de produzir um ciclo de operações, sendo que o operador da máquina vai repetir algumas ações físicas. Finalmente, na década de 1950, as atividades que o homem exercia sobre a máquina passaram a ser substituídas por sistemas de automação e por aparelhos mecânicos e eletrônicos. Bruna (1976) atenta para este momento da indústria como uma possibilidade de estender este processo à construção civil. Para ele seria possível atender às especificidades de cada obra mantendo a eficiência do processo industrializado. Esses processos de automação estavam se estendendo inclusive para os processos de transporte e deslocamento de materiais e também para os métodos de inspeção e controle.

Bruna (1976) destacava também a relevância de se aprofundar as análises em relação à conceituação dos termos da indústria da construção civil. Nesse sentido, enfatiza a distinção entre os conceitos de pré-fabricação e industrialização. A produção industrial pressupõe a organização e produção em série, com base na repetição ou interação das atividades. A mecanização dos meios de produção também está presente. Mas o fator 
essencial é a superação do artesanato e de seu caráter de produção unitária para alcançar a repetição e a homogeneidade dos produtos. A pré-fabricação, por sua vez, pode ser entendida apenas como uma fase da industrialização, uma vez que não pressupõe organização e produção em série (BRUNA, 1976).

A industrialização plena da construção ainda não é uma realidade no Brasil. Diversas pesquisas, entretanto, mapearam e analisaram processos de racionalização do setor durante as últimas décadas, que colaboraram para melhorar os processos de produção da ICCSE. Não se trata de afirmar que todos os problemas foram solucionados, mas sim de observar que o desenvolvimento das atividades da construção não necessariamente seguirá o padrão de outras indústrias.

\section{A habitação como alavanca da ICCSE}

A produção habitacional frequentemente fomentou o desenvolvimento do setor da construção, inclusive do ponto de vista tecnológico. No Brasil, os momentos nos quais a promoção da habitação foi intensificada correspondem justamente aos períodos de maior desenvolvimento da ICCSE.

De acordo com Barone (1999) o período de 1920 até o pós-guerra pode ser entendido como o primeiro momento representativo do desenvolvimento da ICCSE, marcado principalmente pelo movimento da Arquitetura Moderna. Os preceitos tayloristas e fordistas serviram como base dessa produção que tinha como figura importante Le Corbusier. A intenção era importar da indústria automotiva os modelos de organização e aplicá-los dentro da produção da construção civil. No contexto internacional, diversas experiências foram marcadas pela parcelização, seriação, pré-fabricação etc. das atividades da construção (BARONE, 1999).

Trazendo para o cenário brasileiro, Barone (1999) destaca que o desenvolvimento da indústria da construção está intimamente relacionado aos aspectos estruturais do país, e daí se coloca a importância de identificar as principais guinadas do setor e de se compreender o contexto do momento. 0 início do desenvolvimento da indústria da construção no Brasil - desde 1920 até o pós-guerra - foi marcado pela execução de obras viárias. As obras de grande porte ficavam a cargo de empresas estrangeiras enquanto obras menores eram executadas por empresas nacionais. A expansão das chamadas 'obras urbanas' fomentou, portanto, a criação de empresas construtoras. Especificamente, 
a construção de edifícios tinha como tecnologia central o concreto armado, o que permitiu a utilização de máquinas como betoneiras e bombas de concreto, por exemplo (BARONE, 1999).

As empresas construtoras da época buscaram modernizar a ICCSE com base no processo europeu, marcado pelo aumento da escala e também da produtividade, pela redução de custos e por iniciativas de racionalização. Até então, grande parte da mão de obra era de origem europeia, altamente qualificada e politizada. Nesse período, o Estado tornou-se mais presente dentro da produção habitacional, através de oferta de subsídios e de outras iniciativas de políticas habitacionais. 0 contexto da época definia-se pelo crescimento das cidades e a consequente necessidade de resolução dos problemas habitacionais (BARONE, 1999).

As duas décadas posteriores, 1950 e 1960 foram marcadas pela construção de Brasília e pela criação do Banco Nacional de Habitação (BNH), em 1964. Ambos os eventos estimularam o desenvolvimento da indústria da construção civil. Em relação ao BNH, havia também o objetivo de gerar empregos e dinamizar a indústria de materiais e componentes da construção (BARONE, 1999).

Koury (2007) discutiu três formas de organização do setor da construção civil no período inicial da modernização urbana no Brasil. Uma delas buscava a melhoria técnica do setor a partir do desenvolvimento da indústria fomentado pelo poder privado. Outra previa tal desenvolvimento baseado no poder do Estado e apostando na implementação de processos de pré-fabricação - o que não ocorreu efetivamente, pois a mão de obra continuava braçal apesar de avançados modelos de cálculos estruturais. Finalmente, o terceiro tipo de organização buscava a construção por autogestão, com materiais simples e disponíveis e o conhecimento técnico deveria ser ensinado às organizações de autoconstrução pelos arquitetos. Tais modos de organização foram pensados como solução técnica para as tendências de modernização do Brasil nos anos 1960. A produção da moradia era uma das pautas mais relevantes dentro desse projeto de desenvolvimento e se previa, naquela época, que a habitação deveria ser promovida em larga escala, a partir de soluções industriais.

Com objetivo de conduzir as atividades construtivas a um patamar elevado de desenvolvimento foram criadas algumas instituições de estudo voltadas ao setor da 
construção. Koury (2007) destaca o Centro Brasileiro da Construção (CBC) ${ }^{40}$ e o Mestrado em Industrialização das Construções da Escola de Engenharia de São Carlos ${ }^{41}$.

0 projeto desenvolvimentista brasileiro fomentou o início da discussão acerca das inovações necessárias no setor da construção civil. Para que se atingisse o patamar da grande escala de produção, era necessário que todo o setor se desenvolvesse, assim como as técnicas construtivas e a formação de mão de obra, e o objetivo principal a ser atingido era a produção habitacional.

Um quarto de todas as habitações produzidas no país - no período de 1964 a 1986 - foi financiado pelo $\mathrm{BNH}^{42}$. Apesar da tentativa de se produzir habitação para as classes de menor renda, a produção acabou se dividindo entre obras públicas e segmento imobiliário, sendo que o Estado permitiu a grande lucratividade das empresas construtoras e o mercado imobiliário alcançou seus ganhos através da localização dos empreendimentos e dos tratamentos estéticos dos edifícios. Ou seja, as questões da industrialização e das inovações tecnológicas não tiveram espaço frente aos interesses econômicos dos agentes envolvidos nesta produção (MOURA, 2011).

Alguns grandes conjuntos habitacionais, contudo, foram construídos a partir de incentivos - do próprio BNH - às inovações tecnológicas, principalmente lançando mão de sistemas pré-fabricados de estrutura e vedação.

Tal pressuposto partia do princípio de que a redução do prazo de execução, possibilitada por sistemas industrializados de construção, permitiriam o barateamento da moradia, apesar dos elevados custos iniciais em equipamentos e tecnologia. Neste contexto, a geração de emprego estaria assegurada pelo volume das obras, muitas da quais envolviam a execução de milhares de unidades habitacionais numa mesma área. (MOURA, 2011, p.78)

\footnotetext{
${ }^{40}$ No final da década de 1960, o CBC buscava a interação entre o setor profissional e a indústria da construção e já tinha como foco a produção habitacional. Para atender às expectativas do Banco Nacional da Habitação (BNH), o CBC investiu em pesquisas de compatibilização e padronização de componentes com o objetivo de racionalizar ao máximo os canteiros de obras.

41 "O Mestrado em Industrialização foi criado no começo da década de 1970 e pode-se afirmar que também teve como objetivo final a produção habitacional. 0 foco do estudo eram os elementos pré-moldados de argamassa armada que possibilitavam uma construção leve, de fácil produção, distribuição e montagem. Este sistema poderia, portanto, ser industrializado e utilizado na produção racionalizada de moradias" (KOURY, 2007, p. 199).

${ }^{42} \mathrm{~A}$ produção do BNH chegou a 4,4 milhões de moradias, ou seja, a produção total de habitação do país alcançou aproximadamente 17 milhões de unidades (MOURA, 2011).
} 
Entretanto, as tecnologias acabaram importadas e a lógica produtiva - ou seja, o trabalho no canteiro - se manteve manufatureira, com a intensa utilização de mão de obra e baixo nível de organização gerencial. 0 resultado foi a qualidade questionável - construtiva e urbanística - dos conjuntos habitacionais e a não consolidação dos avanços tecnológicos pretendida com os investimentos (MOURA, 2011).

Por outro lado, ampliou-se o uso de serviços mecanizados e foram introduzidos alguns novos materiais e componentes no canteiro de obras. Surgiram também algumas iniciativas de pré-fabricação - o que, conforme discutido anteriormente, não significa industrialização - e terceirização da mão de obra.

Nota-se que de certa forma existe um consenso entre os autores no que diz respeito às dificuldades de implementação de uma cultura de industrialização da construção civil, e que mesmo sendo uma bandeira do movimento moderno na arquitetura, os sistemas industriais por vezes não tiveram o papel de destaque como grande parte dos arquitetos almejava ${ }^{43}$.

Após o período do BNH, ocorreu um grande vácuo na produção massiva de habitação no país, até o início dos anos 2000, quando a iniciativa privada passou a ter um protagonismo ainda maior na política habitacional do país. As grandes empreiteiras e incorporadoras passaram a promover obras de grande envergadura no ramo da moradia social, a partir de uma combinação de fatores políticos e financeiros que veremos a seguir. Esta forma de produção evidentemente criou uma nova dinâmica dentro e fora dos canteiros de obras.

\footnotetext{
43 Um exemplo disso, colocado por Koury (2007), foi o projeto para alojamento de estudantes da Universidade de São Paulo, de 1961, pensado por Eduardo Knesse de Melo, Joel Ramalho Jr. e Sidney de Oliveira. Seriam 12 edifícios, dos quais metade seria executada com sistema tradicional e a outra metade com sistema pré-moldado. 0 prazo era curto - os edifícios serviriam como alojamento para os atletas que disputariam os jogos PanAmericanos daquele mesmo ano - e evidentemente surgiram dificuldades na execução dos pré-moldados, que era uma novidade naquela época. Ocorreram problemas de compatibilização do projeto com o sistema de prémoldado e também em relação à mão de obra, pouco experiente em relação a este processo construtivo. Contra a expectativa dos promotores imobiliários - que apostavam no sistema pré-moldado - os edifícios executados através do método tradicional foram concluídos primeiro.
} 


\subsection{Racionalização}

Observamos que parte dos autores que analisaram o setor da construção entendia ser necessário atingir a industrialização completa da produção, do ponto de vista dos preceitos da industrialização clássica. Desse modo, a ICCSE superaria os estigmas da baixa produtividade e dos altos custos rompendo com o fardo do atraso. Guiados por esses estudos, novas análises sobre a construção civil surgiram e vislumbraram sinais de desenvolvimento da ICCSE. São os estudos que, em nossa visão, constroem uma segunda tendência no debate acerca da produção da construção civil de edificações, que entende que, ao longo das últimas décadas, a ICCSE passou por diversos processos de racionalização da produção e, mesmo que não tenha atingido a industrialização completa - seguindo os preceitos clássicos do taylorismo e do fordismo - teve avanços consideráveis em estratégias de gestão, tecnologia e finanças. Por esses avanços, os estudos que enquadramos na segunda tendência refutam o estigma do atraso da ICCSE.

\section{O canteiro como particular}

Comecemos pelo enunciado de um paradoxo. Que se formula de maneira simples quando se observa que, enquanto ocupa uma proporção grande da população operária total, entre as mais elevadas de todos os setores de produção, e detém um papel chave na acumulação do capital, o canteiro permanece uma das formas de produção menos conhecida e talvez a menos compreendida (CORIAT, 1983, p.1).

Coriat (1983) inicia o texto "O processo de trabalho de tipo 'canteiro' e sua racionalização" justamente com a passagem acima. Nela, apresenta um paradoxo que se constrói a partir da grande relevância do setor da construção frente à incompreensão acerca do funcionamento de seu espaço de produção, o canteiro de obras. Tal paradoxo é explicado pelo autor através da "diversidade de tipos de fabricação que o canteiro tem por vocação produzir" e pela utilização do taylorismo como unidade de referência para os estudos (CORIAT, 1983).

Sucintamente podemos afirmar que Coriat (1983) compreendia a construção civil através de suas particularidades e complexidades que a diferenciam consideravelmente de outros setores produtivos. Frente a alguns preceitos tayloristas, pode parecer que o setor da construção civil não se desenvolveu satisfatoriamente. O autor vai demonstrar, entretanto, que o taylorismo se tratava de uma referência externa, de outras indústrias, e 
não previa as especificidades da construção civil. Deste modo, não seria sensato insistir em submeter o processo produtivo da construção na concepção elaborada por Taylor.

O panorama traçado por Coriat (1983) nos ajuda a construir um olhar mais crítico quando observamos o setor da construção e não ceder às armadilhas de tentar enquadrar a construção civil em modelos de outros setores produtivos.

Nesse sentido podemos considerar a construção civil como um ramo da engenharia voltado para a transformação de matérias-primas em obras destinadas à satisfação de determinadas necessidades humanas, utilizando maquinário adequado, racionalização e divisão do trabalho. (BARONE, 1999, p.128,).

O canteiro de obras é o suporte para estas transformações que, em nosso recorte de pesquisa, terão como resultado edificações habitacionais. Poderíamos chamar essas transformações de processos de produção que ocorrem em parte dentro dos canteiros de obras (LOVERA, 2011). Ao contrário de outros setores produtivos, no caso da construção civil e mais especificamente na produção de edificações, o suporte onde estes processos são desenvolvidos é mutante, específico e provisório. Isso significa que toda a infraestrutura móvel precisa se adaptar a cada suporte físico, em suma, a cada obra. A cada etapa executada, o contexto da fabricação é modificado, e assim sucessivamente até a conclusão do processo. Podemos afirmar deste modo que efetivamente o produto edificação é o resultado de um conjunto de outros produtos primários executados em etapas e o espaço utilizado para estes processos permanece em constante mudança (BARONE, 1999, p. 128).

O canteiro de obras é, portanto, a "fábrica" onde é produzido um edifício. Porém trata-se de uma fábrica provisória. Assim que uma obra se inicia, todo um aparato é armado para dar suporte aos processos que deverão ser ali executados. Vejamos: para a construção de um empreendimento habitacional o primeiro passo é o tratamento do terreno. Essa primeira etapa consiste em alguns testes para aferir comportamentos do solo e depois, a partir dos resultados obtidos, é realizada a terraplanagem. Equipamentos e máquinas de grande porte geralmente são necessários para este serviço. Nesse momento algumas estruturas já devem estar montadas no canteiro: um pequeno escritório, banheiro, depósito. Então é iniciada a execução das fundações, com outros equipamentos e insumos. Por vezes, a infraestrutura de rede de água e esgoto, pavimentação e por vezes até calçada e jardinagem também são executadas logo no início da obra. Depois desse conjunto de infraestrutura e fundações, a etapa seguinte trata-se efetivamente da edificação. Sistema 
estrutural e de vedação, instalações elétricas e hidráulicas, sistema de cobertura. A partir daí a estrutura do canteiro de obras - a fábrica - precisa ser ajustada. Outras máquinas e equipamentos são utilizados, o número de trabalhadores aumenta consideravelmente, materiais e insumos precisam ser estocados, enfim, o canteiro precisa acomodar todas estas atividades. Começam então as etapas de acabamento, assentamento de pisos e azulejos, pintura, instalação de componentes. Frequentemente nessa fase da obra os espaços no canteiro já são escassos, uma vez que as edificações já foram construídas. Novamente, é necessário repensar o espaço do canteiro, adaptar as instalações, desmontar o que não será mais utilizado. Depois da conclusão de todos esses processos, é o momento de executar a limpeza da obra, tanto das edificações finalizadas quanto do canteiro. Toda a estrutura enfim é provisória e deve ser desmontada, retirada e enviada para o próximo canteiro.

\footnotetext{
0 processo de produção no qual se insere o trabalho do operário da construção dá-se em um contexto de caráter evolutivo-provisório, em que o produto fixo sofre uma intervenção humana que é móvel, caracterizada pelas especificidades de cada ciclo de produção. 0 trabalho é feito sobre o produto de cada etapa anterior e o resultado de cada etapa é, não apenas objeto do trabalho subsequente, mas, igualmente, seu contexto de realização, que se encontra em contínua evolução. (BARONE, 1999, p.128,).
}

De acordo com Panaia (2004), a construção se realiza "in situ", ou seja, espacialmente falando, este fato impõe variadas restrições e tem efeitos diretos nas dinâmicas de produção (PANAIA, 2004).

Não por acaso, a busca pela racionalização da construção passa diretamente pela racionalização do canteiro de obras e pelo desenvolvimento da logística. Isto porque o planejamento dos processos de produção, e consequentemente, do processo de trabalho, necessariamente depende dos estudos de layout do canteiro.

Sob este aspecto, o olhar atento aos canteiros de obras é fundamental para a compreensão das estratégias das empresas acerca do processo produtivo da habitação. 0 aumento da produtividade através da racionalização depende da identificação de pontos de estrangulamento dentro do processo produtivo. Ou seja, é o diagnóstico dos pontos que concentram as falhas e que prejudicam o funcionamento das atividades de produção. Efetivamente, essa é a base da Produção Enxuta (Lean Production), um conceito que surge 
na década de 1970 em meio às transformações produtivas ocorridas a partir do modelo toyotista ou japonês ${ }^{44}$ (VILLELA, 2007).

De acordo com a visão de Villela (2007), uma das primeiras evidências da apropriação da produção enxuta na produção da construção civil dentro do subsetor de edificações foi justamente em relação ao uso de recursos e desperdícios. Dentro dessa estratégia, é necessário identificar as falhas - ou os pontos de estrangulamento - a partir de um diagnóstico geral da produção, e é aí que entra o canteiro de obras (VILLELA, 2007).

Algumas dessas falhas seriam o desperdício de materiais, o retrabalho, as paradas e esperas, e os custos de manutenção. A partir da visualização destes erros, seriam definidas ações alternativas para evitar e minimizar os problemas. Tais ações são aquelas que, de acordo com Villela (2007), trata-se de uma primeira tentativa de implementar estratégias do modelo toyotista na produção de edificações. A questão aqui é que o diagnóstico dos ditos pontos de estrangulamento só é possível a partir de uma leitura ampla das atividades do canteiro e efetivamente, de seu próprio funcionamento. E, do mesmo modo, as soluções ou as ações para minimizar as falhas partem do planejamento cuidadoso do canteiro de obras (VILELLA, 2007).

A produção enxuta é baseada em uma série de princípios que visam aumentar a produtividade e reduzir os custos. 0 planejamento dos processos de produção tem um papel fundamental dentro dessa filosofia. Dentro do campo da construção este planejamento perpassa necessariamente o canteiro de obras, a partir dos estudos e desenvolvimento do 'layout', que vem da ideia de 'logística'. A logística, dentro da lógica empresarial tem a ver com o planejamento e o controle dos fluxos e armazenagem de matérias primas e do estoque em um processo produtivo, tratando de todas as etapas, desde a origem até o consumo. 0 planejamento e o controle das matérias primas, seus fluxos e armazenagem, na construção civil, se traduzem justamente no planejamento do canteiro, ou seja, no layout. Os estudos prévios dos canteiros colaboram para a melhoria

\footnotetext{
${ }^{44}$ A Lean Production tem como objetivo reduzir os custos de produção e aumentar a competitividade e consiste em um conjunto de técnicas elaboradas a partir da década de 1970 por fabricantes japoneses da indústria automobilística. São quatro princípios: trabalho em equipe; comunicação; uso eficiente de recursos e eliminação de desperdícios; e melhoria contínua.
} 
da produtividade, adequação e otimização dos processos de produção, higiene e segurança do trabalho (VILELLA, 2007).

A otimização da produção dentro das atividades da construção habitacional era possível, segundo Farah (1992) a partir de 'estratégias de gestão de processos', que efetivamente se tratava de projeto e planejamento da obra. Tais estratégias, na época, eram restritas a empresas de certos segmentos produtivos. Farah (1992) identificava dentro das atividades da construção, uma intensa improvisação nos processos de produção. Justamente a estratégia de gestão de processo busca romper com o improviso comum ao setor através de ações de projeto (como compatibilização de projetos), e também de ações de planejamento e controle de execução. Neste segundo conjunto de ações podemos enquadrar as estratégias de planejamento e otimização dos canteiros de obras.

O controle dos fatores que interferem na obra está diretamente relacionado à redução da variabilidade quando possível e ao controle da variabilidade que não se pode excluir como, por exemplo, questões climáticas. Este controle se faz a partir de ações sobre as áreas e atividades de apoio do canteiro de obras, como suprimento e armazenamento de materiais e insumos, transporte e circulação, que são geralmente pontos de estrangulamento das atividades da construção. A definição prévia do layout do canteiro prevendo a localização adequada às instalações provisórias e suas dimensões, os espaços para estocagem e também boas estratégias de organização e gestão dos materiais - se trata de uma questão importante dentro do processo de racionalização da produção.

\section{Os momentos da racionalização da ICCSE}

\footnotetext{
Na construção, tanto a natureza quanto o ritmo das mudanças no processo produtivo se distinguem dos padrões clássicos de industrialização. Nesse setor, a acumulação tem se dado sem que a base técnica sofra uma transformação radical no sentido da mecanização do canteiro de obras e sem uma ruptura da estrutura de ofícios, organização do trabalho tradicional neste ramo de atividade (FARAH, 1992, p.51).
}

Farah (1992) apresenta uma análise de grande destaque dentro da discussão da ICCSE, particularmente em relação à produção da habitação. Assim como os autores que inserimos na primeira linha do debate, Farah (1992) identifica algumas especificidades do setor da construção que impediram sua industrialização completa. Dentre essas especificidades, a autora ressalta a questão da variabilidade - tanto externa quanto interna - presente nas atividades da construção. Em relação à variabilidade externa, 
refere-se ao caráter individual e exclusivo do produto habitação, que depende inclusive da questão imobiliária. Já a variabilidade interna é colocada como a diversidade inerente ao processo produtivo das edificações. Essas particularidades, contudo, não representavam um impeditivo incontornável ao desenvolvimento da ICCSE em sua visão.

\begin{abstract}
A variabilidade inscrita no processo de trabalho na construção impõe limites à padronização, à produção em série, à repetitividade e, portanto, à prescrição estrita do 'como fazer' pela gerência, característica do taylorismo. Mas deparar-se com limites de evolução nesse sentido não significa estagnação, como sugere, de forma implícita a noção do atraso. Assim tem havido, ao longo do desenvolvimento da construção de edificações habitacionais no Brasil, uma série de mudanças no plano tecnológico e da organização do trabalho (FARAH, 1992, p.52).
\end{abstract}

Durante a expansão do setor da construção - entre as décadas de 1960 e 1980 - os custos da construção propriamente dita tinham um papel secundário em relação aos custos das atividades não produtivas - como o sobrelucro imobiliário. Farah (1992) elenca três mecanismos que as empresas utilizaram para reduzir os custos de construção no período de expansão da ICCSE: redução da área das habitações; rebaixamento da qualidade dos materiais e componentes construtivos; precarização das condições de trabalho. Evidentemente, o resultado da produção habitacional desse período foi bastante questionável, com moradias de baixíssima qualidade executadas por trabalhadores em péssimas condições de trabalho. Não havia, tampouco, participação ou organização dos usuários finais durante o processo de construção das unidades e, além disso, o poder público se omitiu frente a essas questões (FARAH, 1992).

A partir dos anos 1980 a expansão do setor foi interrompida pela crise econômica e os sistemas de financiamentos habitacionais foram abalados. 0 resultado foi uma crise no setor residencial que se estendeu para toda a ICCSE. Essa crise levou as empresas construtoras a reconsiderarem o peso dado aos custos da construção. Além disso, a esta altura os trabalhadores estavam mais mobilizados e exigentes em relação às condições de trabalho. As empresas se utilizaram de algumas estratégias numa tentativa de se adaptarem ao novo contexto, estratégias estas que não ocorreram de modo homogêneo e também não configuraram planos delimitados de ação (FARAH, 1992).

Uma mudança mais radical na base produtiva, entretanto, exigiria grandes investimentos por parte das empresas, o que sem uma grande escala de produção era inviável. As alternativas, portanto, foram pensadas no sentido de minimizar custos melhorando a 
produtividade através da flexibilização dos processos produtivos. Farah (1992) identificou quatro tendências das empresas construtoras:

a) incorporação de novos sistemas construtivos à atividade produtiva;

b) transferência de uma fração do processo produtivo do canteiro de obras para o setor produtor de materiais;

c) intensificação da tendência de subcontratação, através da transferência crescente das atividades de construção a "terceiros";

d) ênfase à gestão do processo produtivo, definindo uma estratégia de racionalização por parte da empresa incorporadora ou construtora. (FARAH, p.56, 1992).

De modo geral, na ICCSE as ações relativas à produção consistiam na inclusão de sistemas pré-fabricados, compatibilização entre componentes, adesão a operações padronizadas em substituição aos saberes de ofício, retirada de atividades do canteiro de obras, incorporação de inovações (materiais e componentes). Todas essas estratégias buscavam reduzir a variabilidade dentro da ICCSE e desse modo aumentar a produtividade.

Villela (2007) vai traçar a periodização do processo de racionalização da construção no Brasil, entre os anos 1920 e os anos 2000, identificando quatro fases da racionalização do processo de trabalho na construção. Essas fases passam pelos fundadores da racionalização entre as décadas de 1920 e 1940; depois, algumas tentativas pontuais que ocorreram entre os anos 1950 e 1970; em seguida, entre meados de 1970 e 1990, a racionalização da ICCSE no Brasil se desenvolveu a partir da introdução do toyotismo; e a última fase que vai até os anos 2000 e que foi marcada pela consolidação da racionalização da construção (Villela, 2007).

Entre meados de 1970 e meados de 1990, ocorreu um processo mais efetivo de racionalização da produção da ICCSE - a terceira fase de acordo com Villela (2007). Naquele momento, as empresas construtoras enfatizaram ações que permitiram ampliar a produtividade, reduzir custos e também garantir a qualidade, por meio do domínio dos processos de trabalho, sem representar grandes alterações na composição orgânica do capital (VILLELA, 2007).

A ênfase, neste caso, recai sobre o projeto, sobre o planejamento da execução e sobretudo sobre a articulação entre as diversas etapas do empreendimento - da comercialização a construção propriamente dita. Procura-se, através de um conjunto de medidas (como declarou um engenheiro envolvido na implementação de tal estratégia em uma das empresas pesquisadas: 'Não são algumas ações isoladas que resolvem... mas um leque de ações'), reduzir a ocorrência 
de erros, minimizar perdas e diminuir tempos ociosos, aumentando a produtividade, através da antecipação da execução, nas fases de projeto e planejamento. Rompe-se, assim com a improvisação característica da construção tradicional, transpondo para obras de edificações em geral procedimentos utilizados por algumas empresas nos grandes canteiros de obra do período anterior. E desenvolvidos inicialmente nos canteiros de obras de construção pesada. (FARAH, 1992, p. 240 apud VILLELA, 2007, p.146).

\section{Villela (2007) identifica nove indicativos da aplicação do modelo toyotista ou japonês na terceira fase da racionalização. É o que ele chama de 'modos de socialização' desenvolvidos pela ICCSE 45 . 0 conjunto formado por esses modos de socialização é chamado atualmente pelas empresas de 'Fast construction'. De acordo com Villela (2007) são eles:}

1‥ A introdução de Princípios da Lean Production - Lean Construction, por meio da racionalização do uso dos recursos que envolve uma análise geral das atividades do canteiro, voltada à identificação dos pontos em que costumam se concentrar os erros, quais sejam, o retrabalho, paradas e esperas, altos custos de manutenção e o desperdício de materiais;

2‥ A implantação de Programas de Qualidade Total que denota a preocupação das empresas com a qualidade do produto e do próprio processo devido às implicações de falhas e imprecisões em termos de retrabalho e de perdas de materiais;

3a. A Racionalização dos Processos de Trabalho em Escritório, por meio da contratação de empresas de consultoria, produz a coordenação entre os diversos projetos: arquitetônico, instalações, estrutura, etc., simplificação da execução, por meio da padronização de peças e componentes, como mecanismo de redução da variabilidade na construção, racionalização no planejamento e no controle da execução;

4ª A Logística e Racionalização do Canteiro de Obras, por meio da racionalização nas áreas e atividades de apoio (tais como: suprimento e armazenamento de materiais, transporte e circulação no canteiro, projeto (layout) de canteiro de obras), a partir do plano de execução, no qual se estuda a localização mais adequada das instalações provisórias (alojamento, escritório, almoxarifado, oficinas, etc.), definindo ao mesmo tempo as dimensões das instalações, a partir da previsão dos recursos necessários ao longo da obra,etc.;

5a. A Horizontalização das Empresas, por meio da racionalização das atividades de preparação de materiais e componentes: retirada do canteiro de obras dessas atividades, por meio da aquisição de produtos e da contratação de serviços no mercado e da instalação de centrais de produção da própria empresa, capazes de atender várias obras ao mesmo tempo;

${ }^{45}$ Cada um desses modos de socialização é abordado de modo aprofundado na tese de Villela (2007). Discutiremos alguns deles nos momentos apropriados. 
6a. A implantação das noções de Learning Organization que se caracteriza pela constante capacitação dos trabalhadores, tanto do engenheiro civil e dos arquitetos quanto os operários da ICCSE, em direção à gestão de suas competências;

7ạ. A Gestão Participativa, tendo em vista o engajamento dos trabalhadores na preservação de uma parcela do saber tradicional e a sua articulação ao novo saber, relativo, novos produtos e a novos equipamentos, e à própria gestão do trabalho;

8a. As Políticas de Engajamento e Fixação dos Trabalhadores à Empresa que se propõem a fixar o trabalhador na empresa, por meio de mudanças organizacionais e de melhorias no padrão de absorção de mão-de-obra;

9a. As Terceirizações, por meio do desenvolvimento de parcerias, onde as empresas definem seu core competence (núcleo de competências) no interior do processo produtivo e transferem as demais etapas para as empresas especializadas (parceiras).

(VILLELA, 2007, p.152)

Uma questão pertinente apontada por Villela (2007) sobre as estratégias da fast construction, do ponto de vista da tecnologia é o avanço da automatização. De acordo com o autor, o termo 'automatização' trata de uma parte restrita de um conceito mais amplo: a 'automação'46. Dentro da ICCSE, a automatização pode ser compreendida como as "tecnologias de base microeletrônica aplicada aos processos de trabalho em escritório" (VILLELA, p.148, 2007).

A recente utilização das tecnologias automatizadas - nos referimos de modo geral a softwares - permitiu o desenvolvimento de novas estratégias de controle dentro das obras, seja em relação ao planejamento e andamento dos processos quanto na organização e logística de materiais e insumos. Antes, sem a automatização, todas as tarefas de controle eram realizadas manualmente, sendo que a informática era acessível apenas a grandes empresas e geralmente auxiliava apenas na elaboração de projetos. A expansão da automatização, por sua vez, fomentou o desenvolvimento da área da Tecnologia da Informação (TI) ${ }^{47}$, que na ICCSE serve de apoio na integração das tarefas dentro das empresas (VILLELA, 2007).

\footnotetext{
${ }^{46} \mathrm{~A}$ automação "diz respeito a todo instrumento ou objeto que funcione sem intervenção humana, podendo ser aplicado a toda máquina ou artefato que funcione desse modo" (VILLELA, p. 147, 2007).

47 "A Tecnologia da Informação (TI) é o conjunto de recursos não humanos dedicados ao armazenamento, processamento e comunicação da informação, e à maneira como esses recursos estão organizados num sistema capaz de executar um conjunto de tarefas" (VILLELA, p. 150, 2007).
} 
A industrialização plena da ICCSE - nos preceitos clássicos do taylorismo e do fordismo não se concretizou até os dias atuais. Muitos estudos, em contrapartida, apresentam situações inegáveis de desenvolvimento do setor da construção, com iniciativas de racionalização do processo produtivo e de gestão, principalmente com base nas estratégias toyotistas. Buscaremos então, a partir de nossos achados da pesquisa empírica, contribuir com o debate sobre o desenvolvimento da ICCSE. 


\section{CAPÍTULO 2}

Trabalho no canteiro: etapas de produção

Este capítulo busca apresentar nossos "achados" de campo que conformam o cerne desta dissertação. A partir da pesquisa de campo e da revisão bibliográfica procuramos elaborar uma análise dos aspectos produtivos dos empreendimentos habitacionais de larga escala, enfatizando estratégias que apontem para tendências de industrialização e ou de racionalização da produção.

Em sua discussão sobre formas de produção do espaço construído, Jaramillo (1987) apresenta algumas conceituações bastante pertinentes. Dois termos que serviram como categorias para o autor nos interessam aqui: 'trabalho direto' e 'controle técnico da produção'.

0 trabalho direto consiste na mobilização da capacidade humana de trabalho nos processos imediatos de apropriação da natureza...

$(\ldots)$

0 controle técnico da produção consiste na capacidade de regular o início da ação dos meios de produção, do ponto de vista dos processos de trabalho: é o caso de funções tais como a coordenação de diferentes indivíduos e de elementos que intervém na produção, a disciplina interna, os ritmos e horários, a programação de tarefas, etc. (JARAMILLO, 1987. p.176). 
Dentro de determinado processo produtivo, o 'trabalho direto' é a ponta final da cadeia, ou seja, dentro da produção de um empreendimento habitacional é 'quem faz' e 'como faz'. Essa categoria engloba os processos de execução, os trabalhadores envolvidos, as máquinas e as ferramentas utilizadas, os insumos, etc. Já o 'controle técnico da produção' é o que controla efetivamente o 'trabalho direto' e aí se trata tanto de 'quem controla' e de 'como controla'. Ou seja, qual é a equipe que a empresa destina para garantir que os processos sejam executados de acordo com o esperado? Quais as tecnologias utilizadas para isso? Quais os elementos de prescrição e de controle do trabalho?

No capítulo anterior, enfatizamos duas vertentes do debate acerca da produção da ICCSE: a primeira que colocava o setor sob a chave do atraso e acreditava na industrialização como modelo ideal para sua modernização; e a segunda, que entendia que existiram diversos processos de desenvolvimento do setor - através de estratégias de racionalização - que o levaram a se modernizar mesmo sem atingir a industrialização completa. Em nossa pesquisa de campo, nos deparamos constantemente com muitas das estratégias de racionalização da produção. 0 desafio de produzir grandes empreendimentos habitacionais exigiu das empresas o aprimoramento de soluções técnicas, de organização e gestão, de controle interno e externo, além de exigir um aporte financeiro elevado. Em contrapartida, foi possível notar ainda muitos traços da construção manufatureira, como o papel fundamental do trabalhador no canteiro, por exemplo.

Neste capítulo, antes de discutirmos os processos de execução em si, abordaremos a etapa inicial, não menos importante que as demais, no que diz respeito à racionalização da produção: o planejamento do canteiro de obras. Depois, seguiremos às análises dos processos de execução que se mostraram pertinentes dentro da discussão sobre a racionalização da ICCSE - aqui discutiremos a prescrição, o trabalho e a tecnologia envolvidos nos processos.

Este capítulo tem o objetivo, portanto, de debater justamente esta produção interna ao canteiro, com todos os seus atores, seus instrumentos e suas regulações. 


\subsection{Planejamento e organização da produção: layout, instalações e armazenagem}

Durante a pesquisa de campo, acompanhamos os canteiros de obras e os processos de execução de cinco empreendimentos habitacionais, de duas empresas construtoras diferentes, que apresentavam entre 350 e 1000 unidades cada um, aproximadamente. As visitas de campo revelaram algumas iniciativas de racionalização da produção nesses canteiros, principalmente através de ações gerenciais e de planejamento.

Um dos 'modos de socialização' que formavam a Fast Construction identificados por Villela (2007) era a 'logística e organização dos canteiros de obras'. Efetivamente, trata-se do planejamento do espaço da construção, a partir de estudos prévios de layout definidos de acordo com os fluxos da obra. 0 objetivo é preparar o suporte para as atividades e assim otimizar as tarefas.

O planejamento busca justamente romper com o improviso, antevendo possíveis gargalos e também a melhor maneira de organizar o espaço em função das atividades que serão executadas. Nas obras observadas, as construtoras se adiantavam aos problemas, buscando ao máximo planejar a produção e evitar assim atrasos, desperdícios e consequentemente, aumento dos custos. Nesse sentido, os estudos prévios do canteiro de obras eram o primeiro passo.

Antes do início da obra, a infraestrutura dos canteiros já era construída: escritórios, vestiários, refeitório, almoxarifado, galpões, etc. As estruturas que serviriam durante toda a obra eram acomodadas, dentro do possível, em áreas onde não seriam construídas unidades habitacionais. As construtoras buscavam concentrar as instalações que precisavam de maior comunicação entre si, como por exemplo, o escritório técnico e o almoxarifado. Aproximar o refeitório do vestiário também era uma estratégia adotada dentro dos canteiros, uma vez que reduzia o tempo que os trabalhadores levavam entre uma atividade e outra. Os materiais e insumos eram armazenados preferencialmente em locais próximos onde seriam utilizados definitivamente. 0 objetivo é reduzir ao máximo a necessidade de transporte e circulação dentro do canteiro de obras.

Trata-se da aplicação da logística na produção dos empreendimentos, a começar pelo entendimento total do processo produtivo: fluxos, prazos, metas, dependências entre 
atividades, etc. A partir daí, desenvolve-se o projeto de layout do canteiro de obras buscando a melhor configuração para a implantação das instalações.

\footnotetext{
Na estratégia de racionalização, destacam-se ainda ações que incidem sobre as áreas e atividades de apoio - tais como suprimento e armazenamento de materiais, transporte e circulação no canteiro - consideradas "pontos de estrangulamento" importantes da atividade de construção. Desenvolve-se assim um projeto (lay out), a partir do plano de execução, no qual se estuda a localização mais adequada das instalações provisórias (alojamento, escritório, almoxarifado, oficina, etc.), definindo-se, ao mesmo tempo, as dimensões das instalações, a partir da previsão dos recursos necessários ao longo da obra. (FARAH, 1992, p.64-65).
}

Como é possível aferir a partir do trecho acima, essa não é uma estratégia nova, já vem sendo implementada na ICSSE desde a década de 1980. Percebe-se, entretanto, que as construtoras estão aprimorando o planejamento e a organização dos canteiros, uma vez que essa etapa já se tornou essencial na produção recente da ICCSE.

\section{Layout}

Apesar de apresentarem diferenças consideráveis quanto ao tamanho do terreno, tipologia das unidades e sistema construtivo, os canteiros de obras dos cinco empreendimentos tinham instalações bastante semelhantes. Foi possível identificar três setores de organização dos canteiros: um setor de apoio aos trabalhadores; um segundo de apoio técnico-administrativo; e um terceiro de armazenagem de materiais.

- APOIO AOS TRABALHADORES: refeitório; vestiários; sanitários; alojamentos.

- APOIO TÉCNICO-ADMINISTRATIVO: escritório; laboratório de teste de concreto; bases de pré-fabricação; bases de preparação de componentes.

- ARMAZENAGEM DE MATERIAIS E EQUIPAMENTOS: almoxarifado; contêineres; galpões; áreas reservadas do canteiro.

Dentre as instalações acima, poucas não estavam presentes em todos os canteiros. Uma delas é o alojamento, que existia apenas nas duas obras de casas térreas. Não coincidentemente essas duas obras foram executadas pela Empresa Regional. As outras três eram da Empresa Nacional que atualmente tem uma política de não manter alojamentos dentro dos canteiros de obras.

O empreendimento ALV_APTO, da Empresa Nacional, foi única obra executada em alvenaria estrutural, o que eliminava a necessidade do laboratório de teste de concreto. 
De qualquer maneira, os blocos estruturais precisavam ser testados, porém tudo era feito em um laboratório contratado fora do canteiro. Nessa obra existia também uma base de pré-fabricação de lajes de concreto o que, nos outros canteiros, não existia devido à diferença entre os sistemas construtivos. As outras instalações estavam presentes em todos os canteiros analisados, em suas respectivas dimensões e quantidades, a depender da necessidade produtiva de cada obra.

Basicamente foi possível observar dois padrões distintos de organização dos canteiros de obras entre os casos estudados, um deles aplicado às obras de blocos de apartamentos e o outro às obras de casas térreas. Como todas as obras de apartamentos analisadas foram executadas pela mesma empresa, assim como as de casas térreas, podemos afirmar que pudemos identificar um padrão de organização da Empresa Nacional e um padrão da Empresa Regional.

No caso do padrão da Empresa Nacional, os canteiros montados para a execução dos blocos de apartamentos tinham suas instalações de apoio espalhadas por todo o terreno, nos espaços que estavam disponíveis em cada momento. Nesses casos, geralmente o layout era modificado no decorrer da obra, ou seja, o canteiro era adaptado às condições de execução.

Isso não significa que nessas obras não houvesse planejamento prévio do canteiro de obras, ou que sua construção fosse realizada de modo improvisado. Justamente, por terem canteiros mais adensados - considerando-se a área disponível no canteiro para cada unidade - os espaços livres eram escassos e este fator exigia um planejamento cuidadoso tanto na organização do canteiro quanto na logística e na gestão da obra.

O caso mais expressivo de modificação de layout do canteiro foi do empreendimento ALV_APTO. No início da obra, praticamente todas as áreas que não seriam edificadas imediatamente eram utilizadas como apoio. Com a evolução da obra algumas mudanças foram acontecendo e alguns espaços não podiam mais ser utilizados. As obras duraram mais de dois anos e o layout do canteiro foi modificado consideravelmente ao longo deste período, conforme pode ser observado nos diagramas apresentados a seguir. 
Imagem 6 - Organização do canteiro de obra, primeira etapa de visitas.

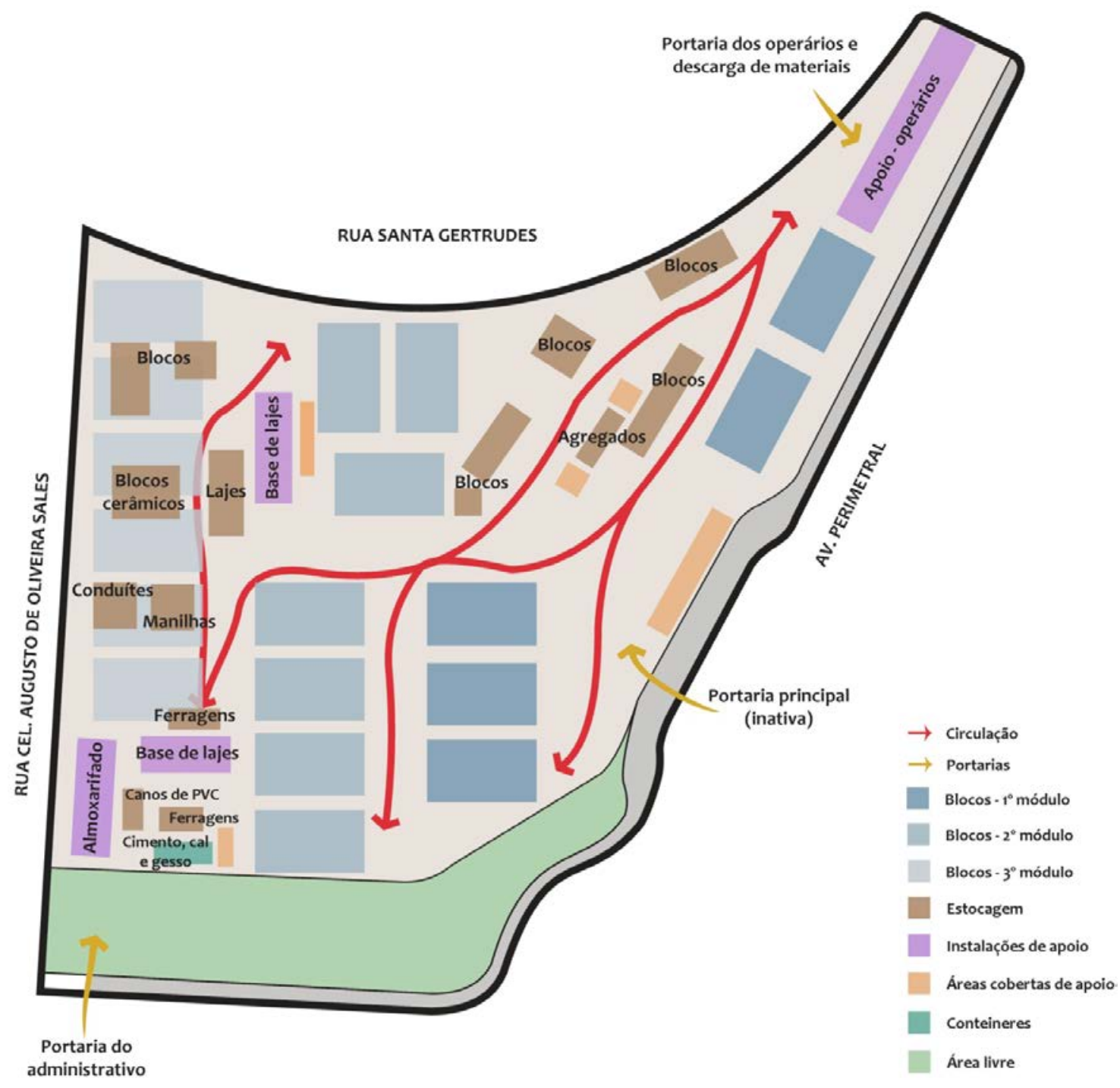

FONTE: Quaglio, 2013. 
Imagem 7 - Organização do canteiro de obra, segunda etapa de visitas.

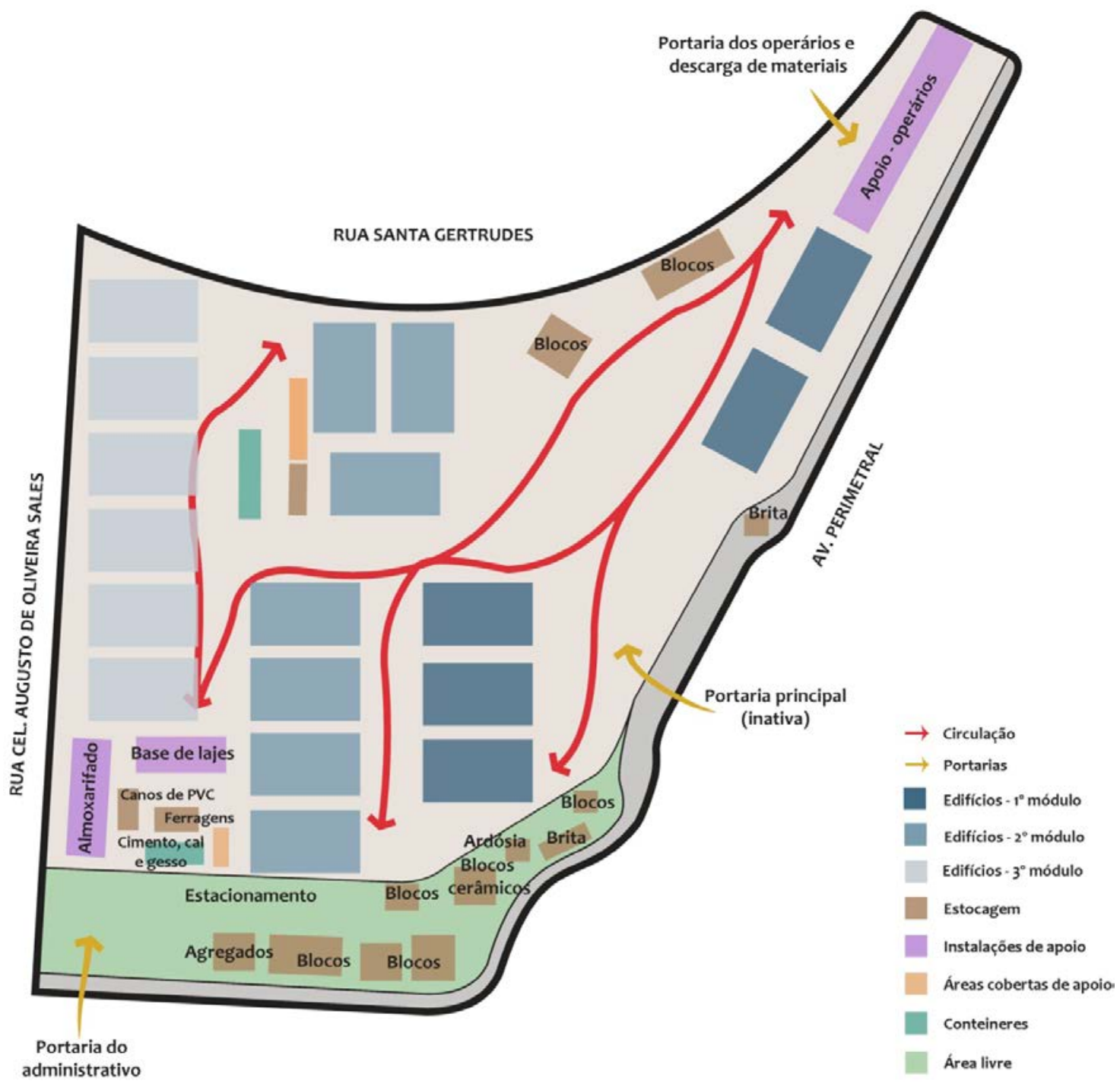

FONTE: Quaglio, 2013. 
Imagem 8 - Organização do canteiro de obra, terceira etapa de visitas.

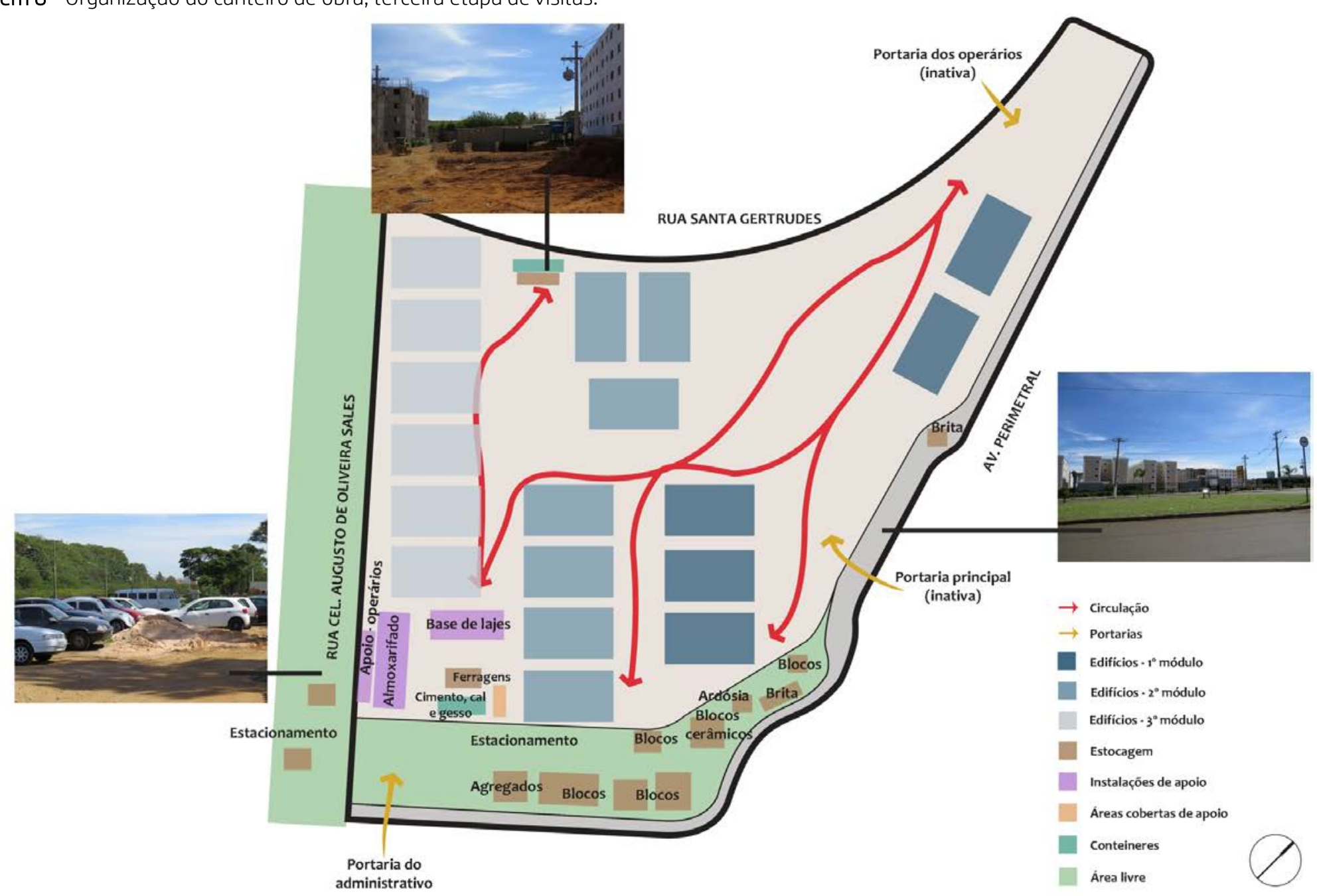

FONTE: Quaglio, 2014. 
O diagrama a seguir apresenta a setorização do canteiro de obras do PC_APTO_1, da empresa Nacional. As instalações foram acomodas de maneira dispersa pelo canteiro, de acordo com os espaços disponíveis.

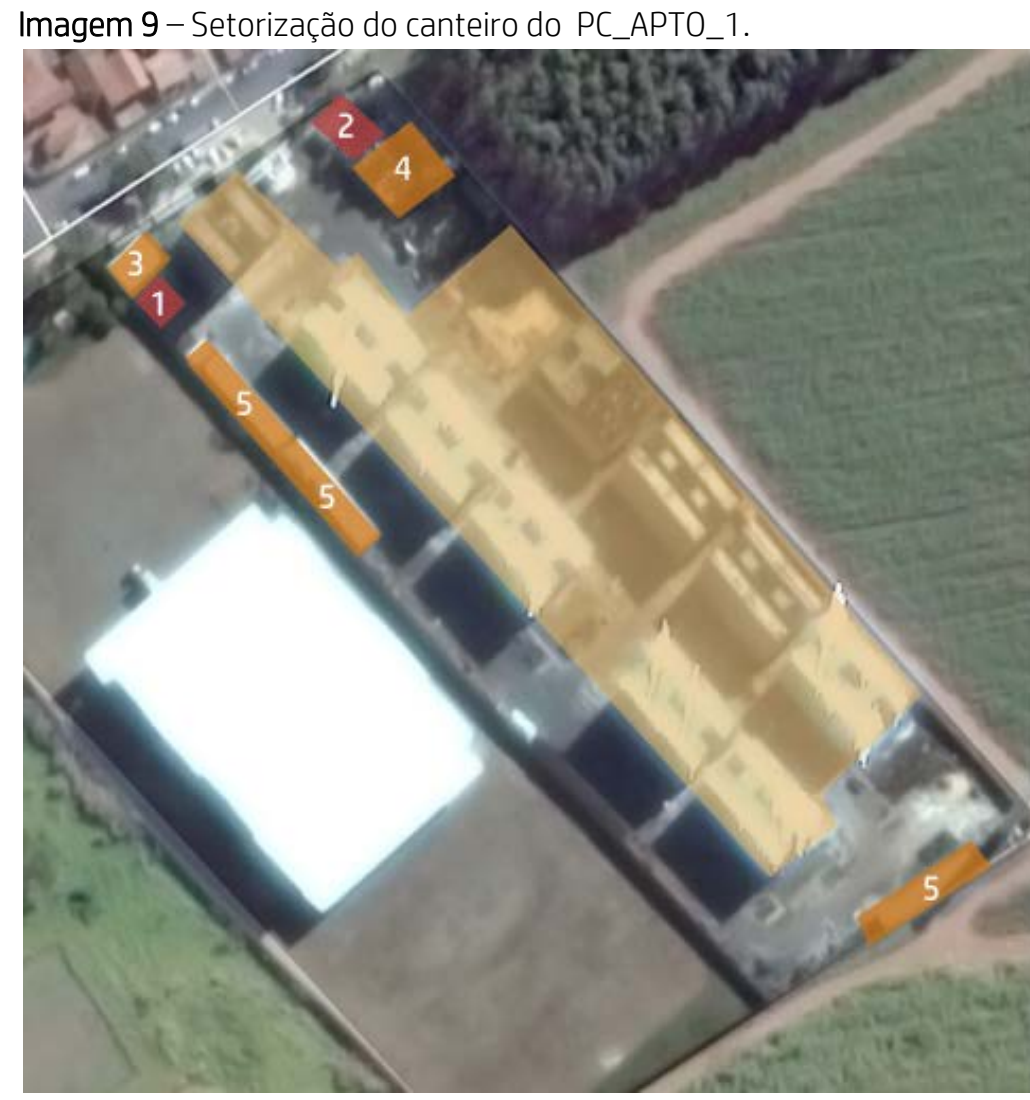

INSTALAÇÕES DO CANTEIRO

1. refeitório

2. sanitários/vestiários

3. escritório técnico

4. almoxarifado

5. estoque e armazenagem

\section{SETORIZAÇÄO DO CANTEIRO}

edificações construídas

apoio técnico

apoio de trabalhadores

FONTE: Elaboração própria a partir de imagem do Google Earth.

Já o segundo padrão, dos canteiros da Empresa Regional, tinha praticamente todas as instalações concentradas em determinado local do terreno e geralmente não sofria grandes modificações no decorrer da obra. As áreas de apoio eram cercadas com alambrado, para que ficassem isoladas da obra propriamente dita. Os alambrados dividiam inclusive um setor do outro, assim, não havia comunicação direta entre as instalações dos trabalhadores e as instalações do apoio técnicoadministrativo, por exemplo.

Nas obras casas térreas existia muito espaço livre disponível que seria utilizado posteriormente para instalações institucionais, por exemplo. Essas áreas não seriam edificadas durante a construção das casas e, portanto, serviam perfeitamente para alojar as instalações de apoio da obra. Desse modo, era possível concentrar toda a estrutura de serviço do canteiro em um mesmo setor, durante toda a execução da 
obra. Sem dúvida essa estratégia facilita a gestão e o controle das atividades do canteiro. Os diagramas a seguir, do empreendimento PC_CASA_1, ilustram o formato de organização dos canteiros da Regional.

Imagem 10 - Setorização do canteiro do PC_CASA_1.

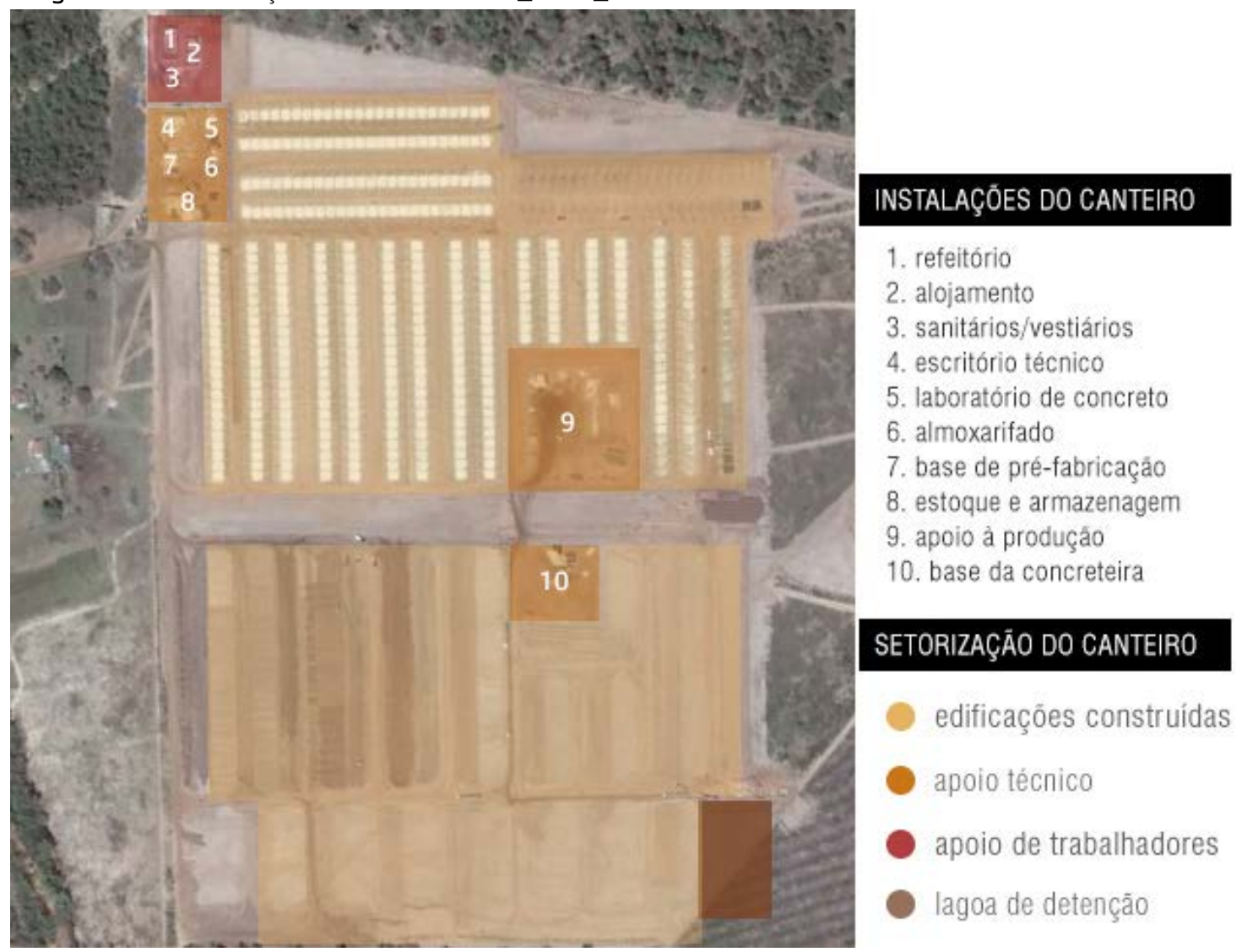

FONTE: Elaboração própria a partir de imagem do Google Earth.

Imagem 11 - Organização das instalações de apoio do canteiro do PC_CASA_1.

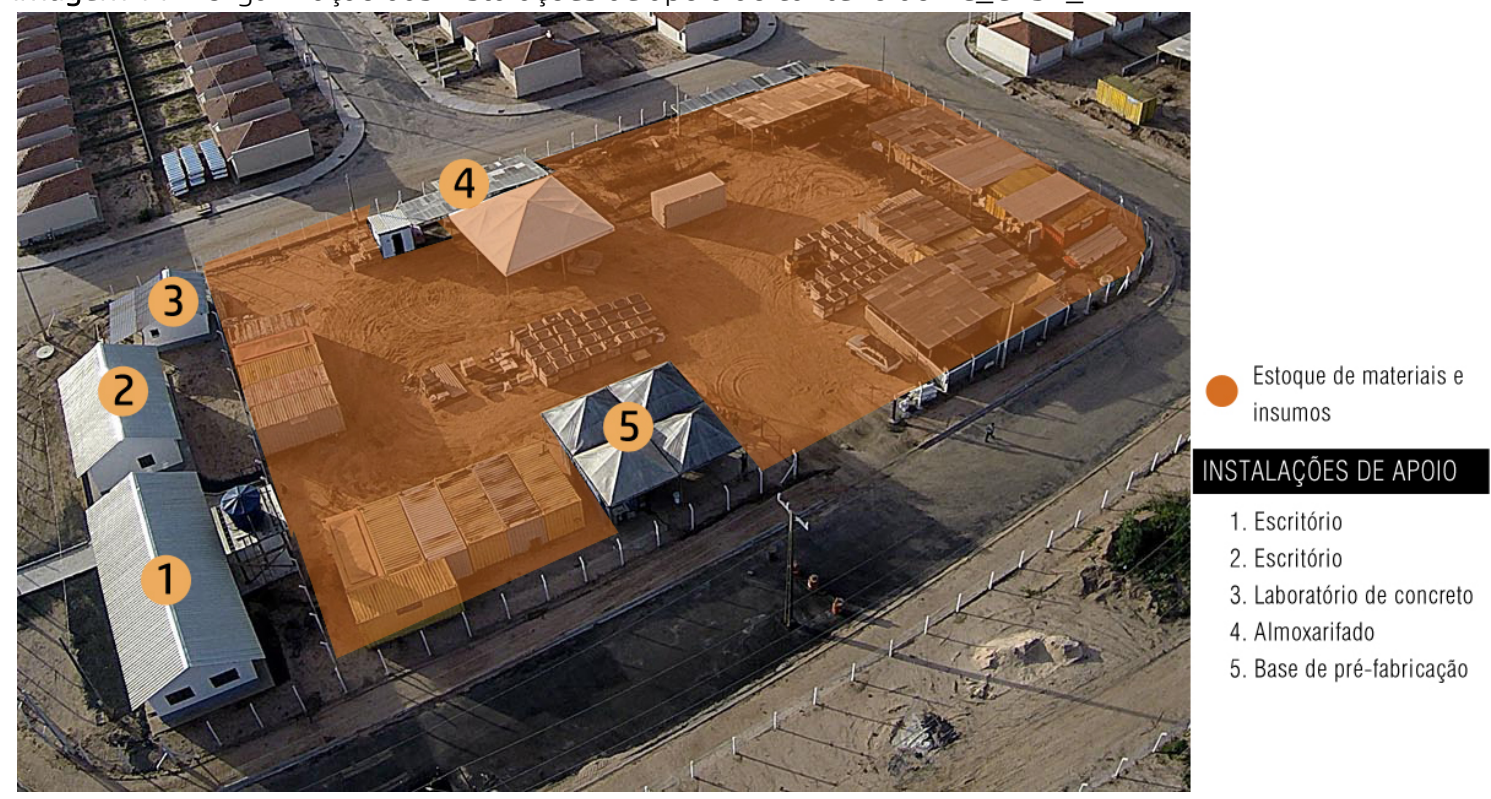

FONTE: Elaboração própria a partir de imagem cedida pela Empresa Regional. 
Imagem 12 - Setorização do canteiro do PC_CASA_2.

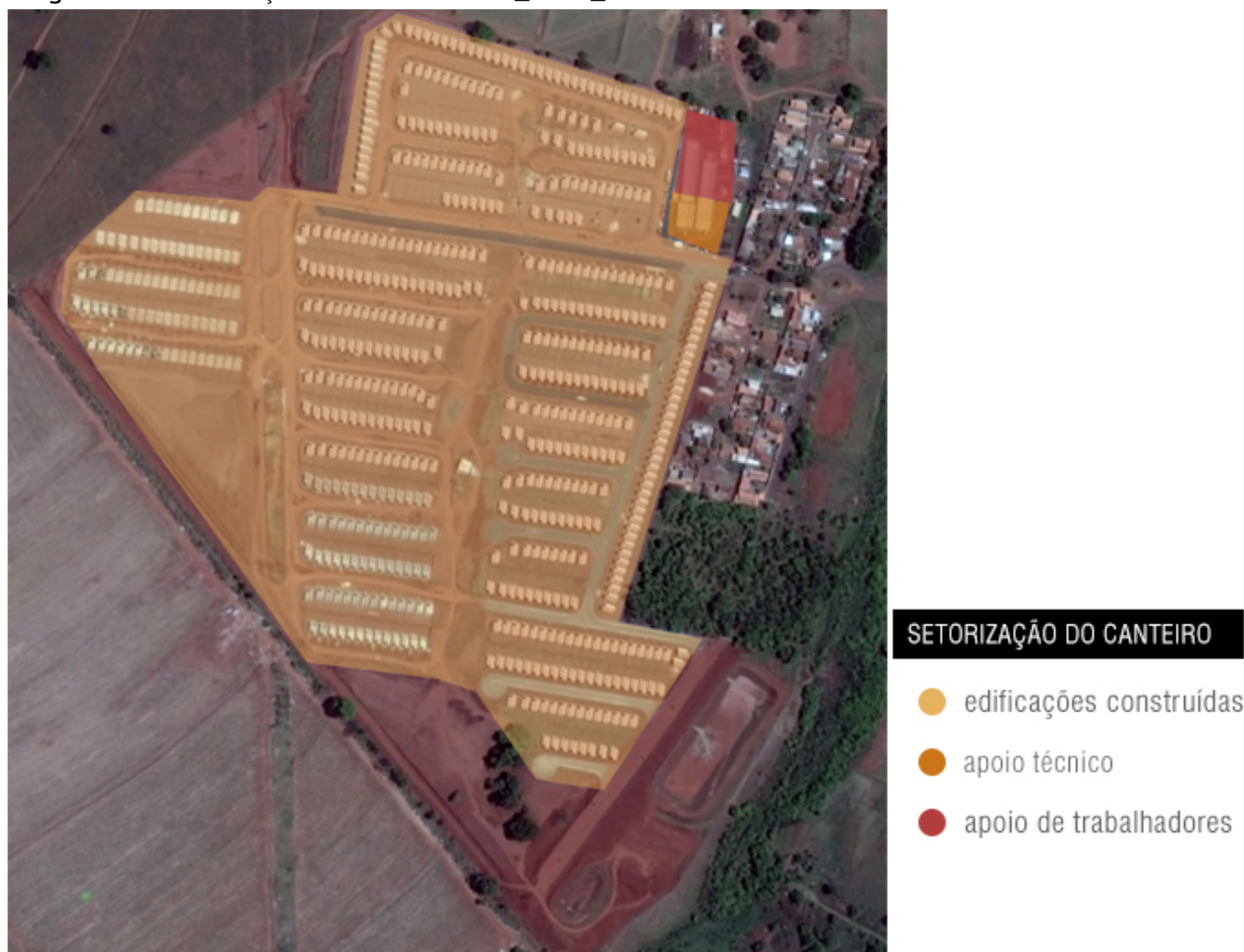

FONTE: Elaboração própria a partir de imagem do Google Earth.

Imagem 13 - Organização das instalações de apoio do canteiro do PC_CASA_2.

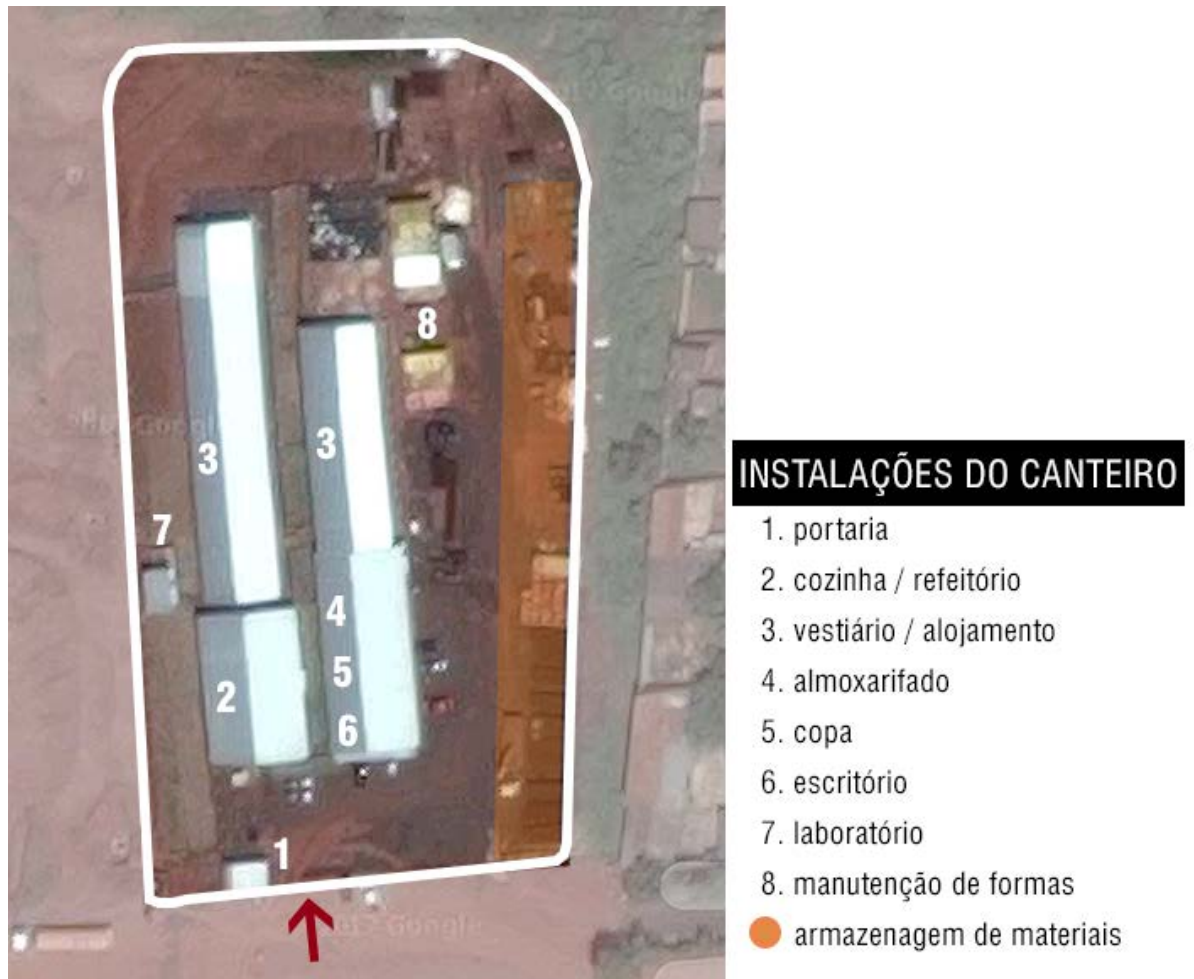

FONTE: Elaboração própria a partir de imagem do Google Earth. 
As edificações de apoio, em todos os canteiros, eram construídas com alvenaria estrutural ou com chapas de compensado e estrutura de madeira. Nas obras da Regional grande parte das instalações de apoio era alojada em edificações permanentes, construídas em alvenaria estrutural. Uma alternativa seria montar todas as instalações de apoio e desmontá-las ao final da obra. A construtora, todavia, buscava firmar acordo com as prefeituras para que as instalações do canteiro fossem doadas para servir como edificações de instituições públicas, por exemplo, posto de saúde e escola. Desse modo, a prefeitura já teria alguns equipamentos construídos e a construtora não precisaria demolir todas as instalações ao final da obra. Um ponto negativo é que nenhuma dessas edificações seria projetada de acordo com seu uso posterior. Efetivamente este uso nem seria definido previamente, o que certamente não é o ideal, principalmente em se tratando de instituições públicas. A construtora também se utilizava, entretanto de instalações provisórias e contêineres.

Na Empresa Nacional, não era comum que os engenheiros optassem por utilizar alguma edificação do próprio empreendimento provisoriamente como estrutura de apoio ao canteiro. No caso do PC_APTO_1, entretanto, isso aconteceu. 0 escritório da obra foi acomodado na estrutura que serviria ao empreendimento como depósito de lixo. Do mesmo modo o futuro salão de festas estava abrigando o almoxarifado e a portaria definitiva estava também servindo à obra. Essas edificações não tinham recebido qualquer tipo de acabamento, somente quando não fossem mais utilizados como almoxarifado e escritório seriam finalizados para a entrega do empreendimento. Esta opção por utilizar a estrutura definitiva do empreendimento (salão de festas, depósitos, guaritas, etc.) como apoio para obra fica a critério do respectivo engenheiro. As estruturas permanentes da obra do PC_APTO_1 não foram suficientes para acomodar todas as atividades do canteiro sendo que algumas outras instalações provisórias precisaram ser construídas. Nos outros empreendimentos da Nacional observados, as edificações permanentes não foram utilizadas durante a obra, provavelmente por escolha dos respectivos engenheiros. 
Imagem 14-Almoxarifado do PC_APTO_1 alojado em instalação permanente.

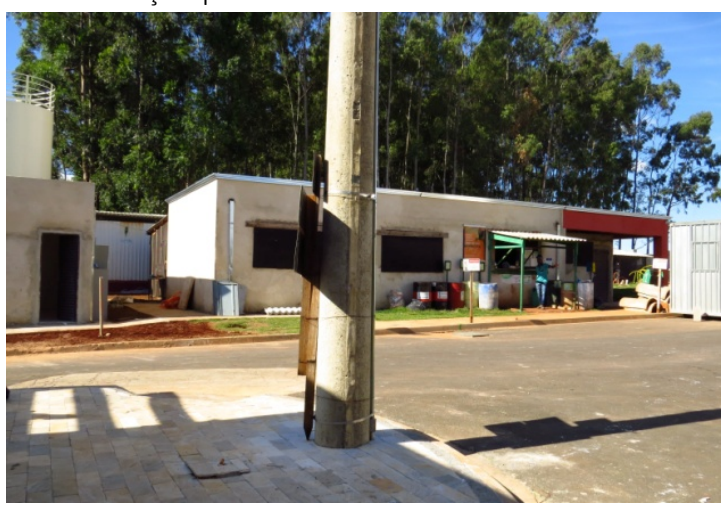

FONTE: Acervo da autora, 2017.
Imagem 15 - Escritório do PC_APTO_1 alojado em instalação permanente.

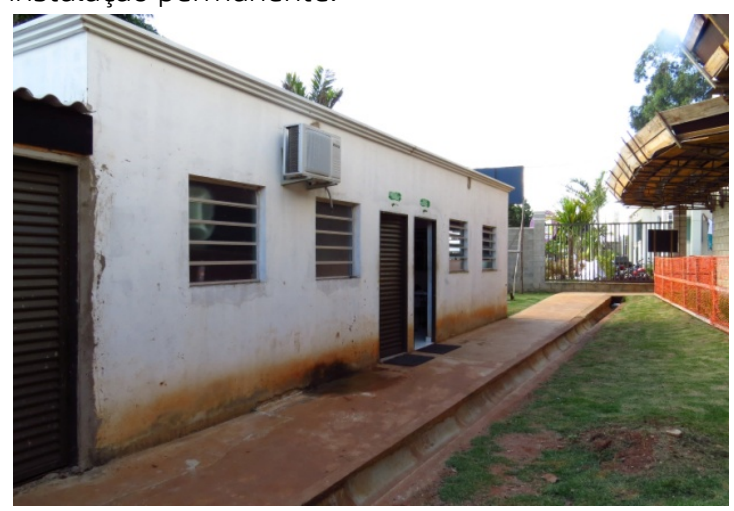

Nos casos aqui apresentados, as instalações dos canteiros eram construídas de acordo com normas técnicas. A norma que regulamenta as especificações das instalações dos canteiros de obras é a NR-1848. Essa norma

[...] estabelece diretrizes de ordem administrativa, de planejamento e de organização, que objetivam a implementação de medidas de controle e sistemas preventivos de segurança nos processos, nas condições e no meio ambiente de trabalho na Indústria da Construção (BRASIL, 1995, p.2).

No caso dos alojamentos devem ser respeitadas as metragens mínimas, números de armários, sanitários, chuveiros, bebedouros e outros acessórios. Nas obras da Empresa Regional os alojamentos eram compostos por quartos que abrigavam um número limitado de pessoas. Dentro de cada quarto havia beliches e armários individuais. 0 vestiário tinha chuveiros, sanitários e lavatórios. Os funcionários contavam também com um pátio coberto, que servia como área de convívio e para lazer dos trabalhadores. 
Imagem 16-Alojamento e refeitório de funcionários do empreendimento PC_CASA_1.
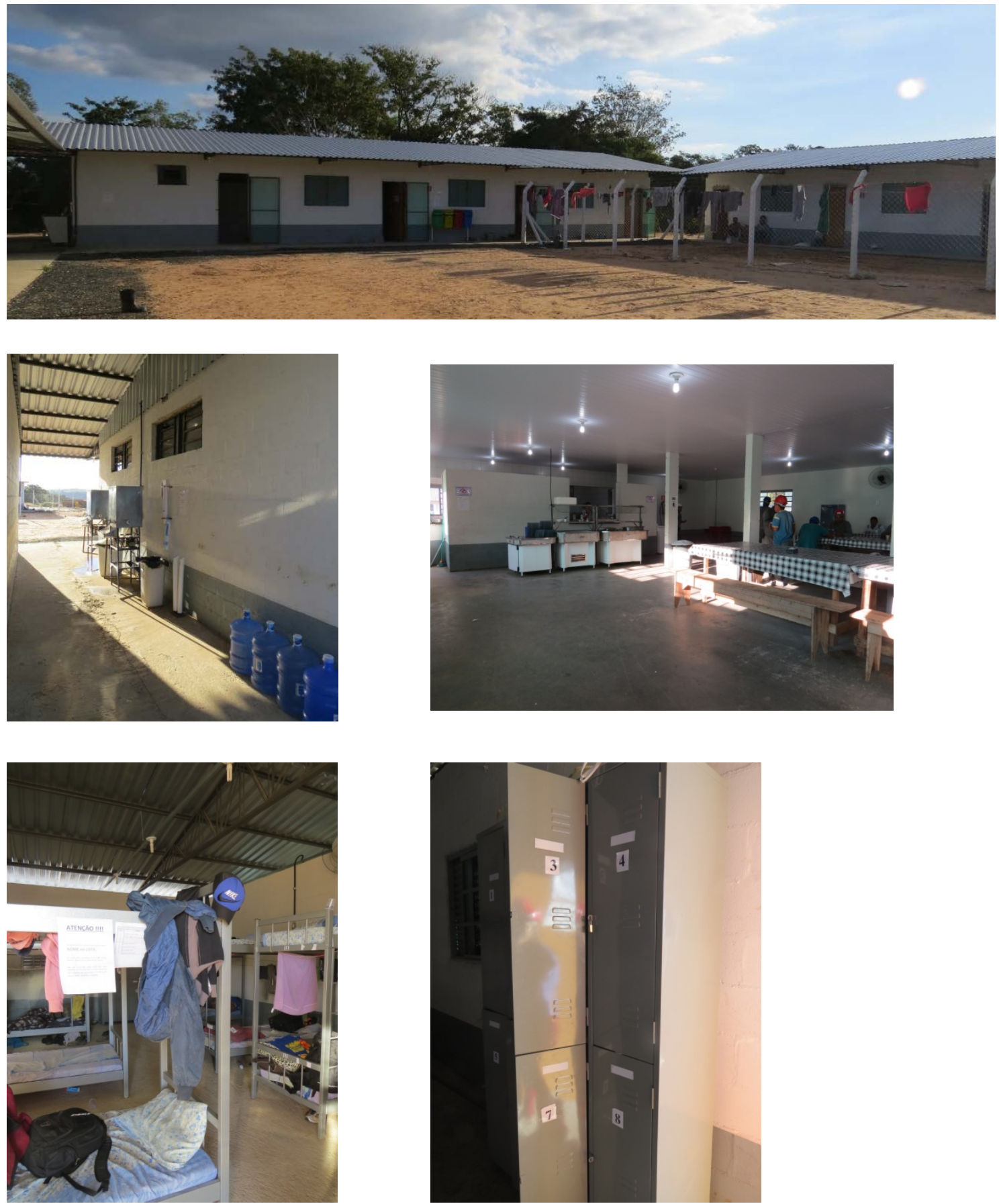

FONTE: Acervo da autora, 2015.

No PC_CASA_2, por exemplo, as instalações foram implantadas basicamente em dois blocos. Um dos blocos abrigava o refeitório, a cozinha e parte dos alojamentos e vestiários. 0 outro abrigava a outra parte dos alojamentos e vestiários e também o escritório, uma pequena copa e o almoxarifado. Essas instalações foram construídas em alvenaria estrutural e cobertura de telha metálica e tinham forro de PVC. 0 
refeitório tinha mesas com bancos que acomodavam cerca 75 funcionários, além de uma mesa de serviço. Geralmente as refeições eram realizadas em dois turnos, portanto o refeitório poderia servir a até 150 pessoas. Todas as refeições eram preparadas no local, a partir da orientação de um nutricionista. Não era necessário, portanto, aquecedores para marmitas, uma vez que os trabalhadores recebiam todas as refeições.

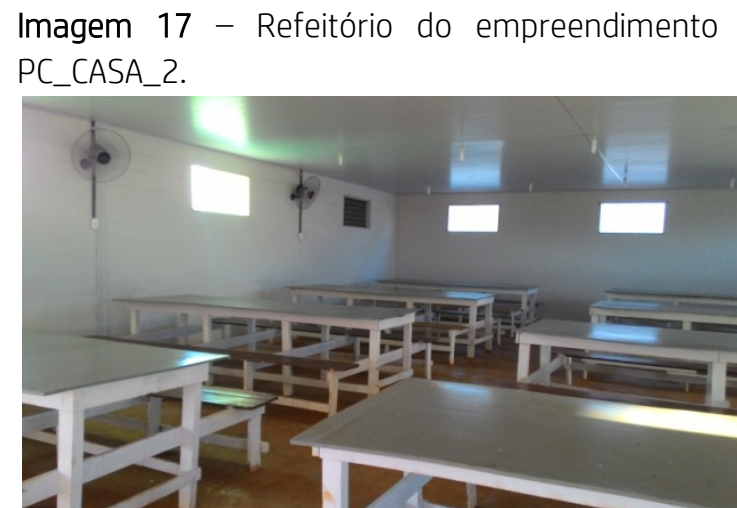

Imagem 18 - Cozinha do empreendimento PC_CASA_2.

FONTE: Acervo da autora, 2016.

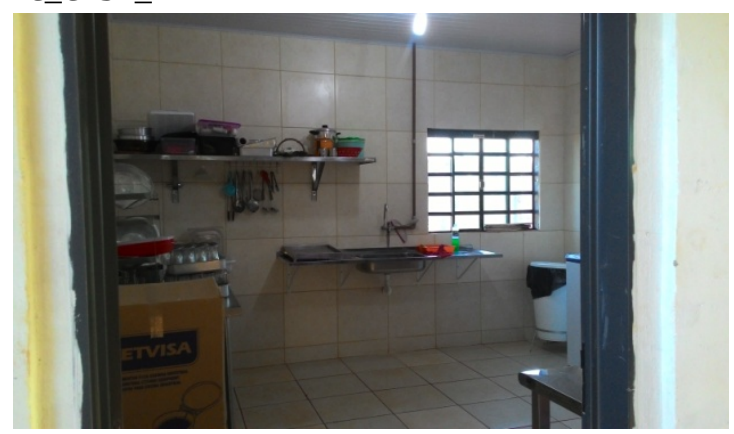

As instalações de apoio técnico-administrativo eram muito similares em todos os canteiros. O conjunto do 'escritório' era formado por salas equipadas com mesas, cadeiras e armários que serviam como escritório para engenheiros, estagiários e auxiliares. Geralmente nas paredes existiam procedimentos de gestão e controle, estatísticas e levantamentos do andamento da obra, além de desenhos da implantação do empreendimento. Existia também copa e sanitários exclusivos para os trabalhadores do escritório.

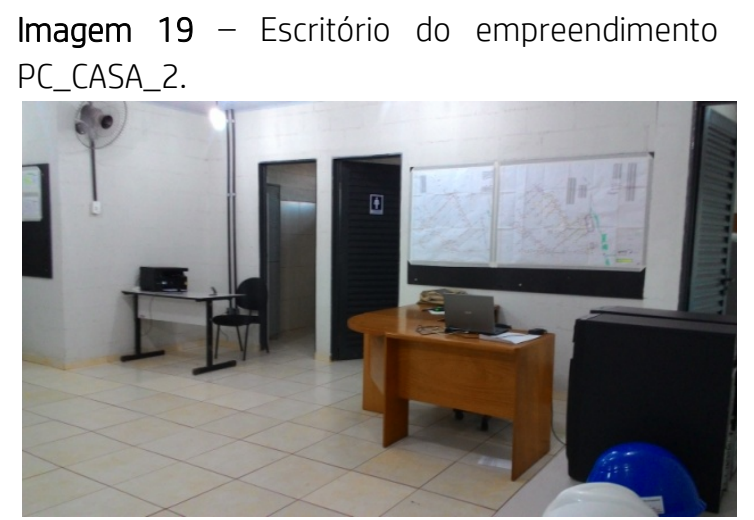

Imagem 20 - Copa do empreendimento PC_CASA_2.

FONTE: Acervo da autora, 2016.

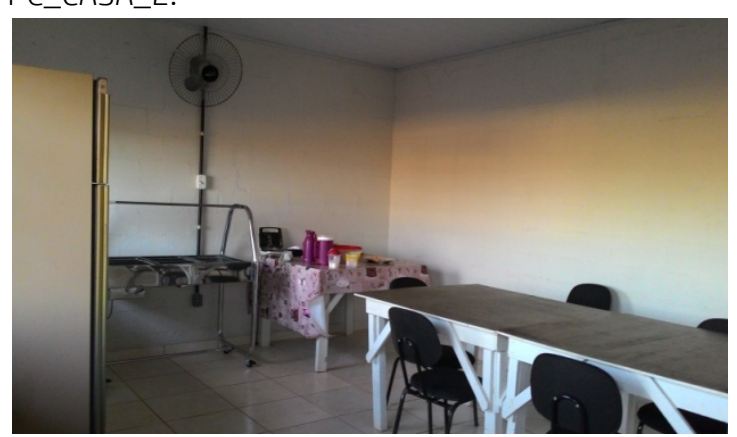


No canteiro do ALV_APTO, por exemplo, uma edificação provisória de dois pavimentos construída com chapas de compensado abrigava no térreo o almoxarifado e no pavimento superior o setor técnico-administrativo. Esta instalação permaneceu no canteiro até a conclusão da obra. Todas as obras da Empresa Nacional têm um escritório próprio, porém, o formato das instalações varia dependendo do tamanho do empreendimento.

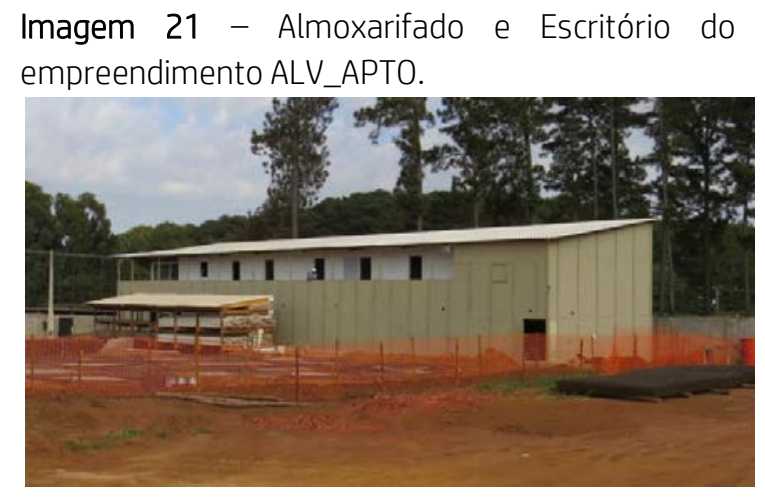

FONTE: Acervo da autora, 2013.
Imagem 22 - Refeitório do empreendimento ALV_APTO.

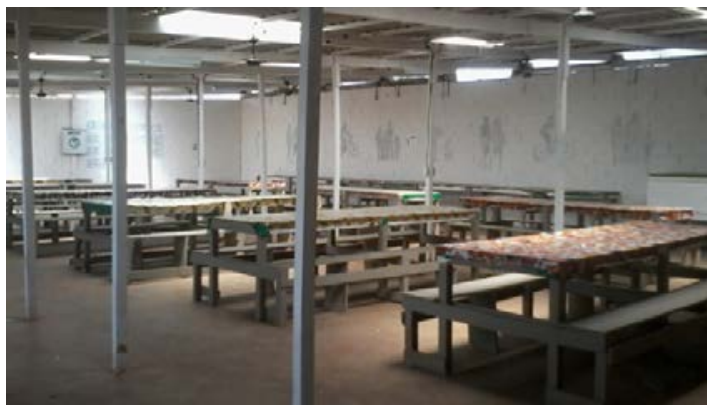

FONTE: Acervo da autora, 2014.

Os laboratórios de concreto eram, basicamente, pequenas edificações, vedadas e cobertas que abrigavam o equipamento para o teste dos corpos de prova. Devido ao curto tempo de cura do concreto utilizado nas obras, as construtoras optavam por manter essa estrutura no próprio canteiro. Dessa maneira, era possível otimizar o processo de teste do concreto.

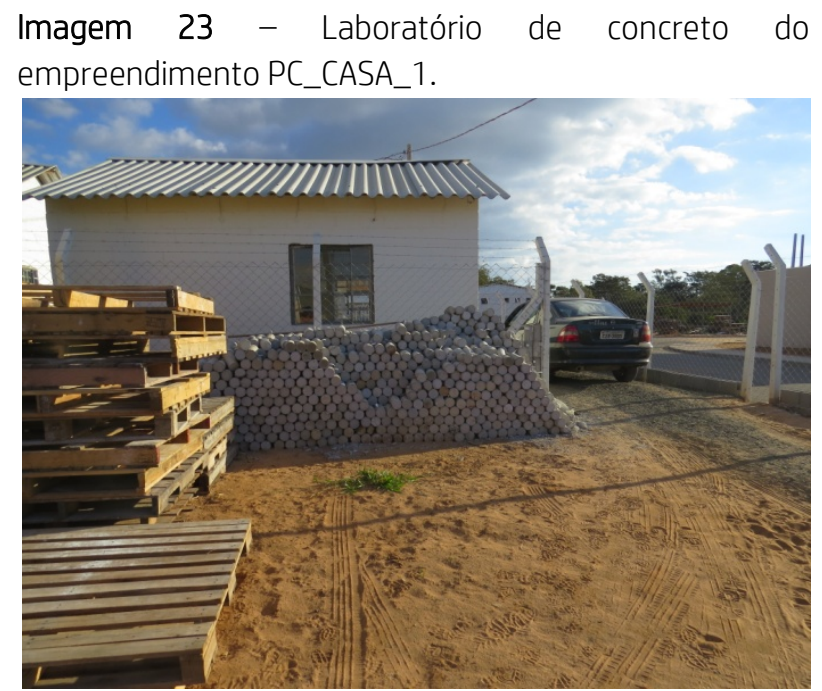

Imagem 24 - Laboratório de concreto do empreendimento PC_CASA_1.

FONTE: Acervo da autora, 2015.

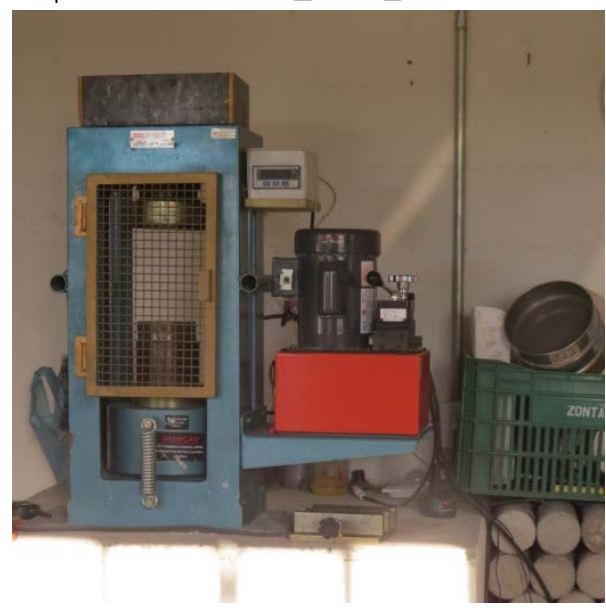


Finalmente, existiam algumas bases de pré-fabricação ou preparação de insumos e componentes. Eram pequenas coberturas com o aparato necessário à respectiva tarefa, como por exemplo, bancadas, ferramentas, equipamentos. Quase sempre ficavam próximas às áreas de armazenagem dos materiais que seriam ali manipulados.

Partindo para o setor de armazenagem de materiais e equipamentos, a instalação principal era o almoxarifado. A capacidade variava de obra pra obra, entretanto as configurações das edificações eram bastante parecidas. Tratava-se de galpões vedados e cobertos, equipados com gôndolas e prateleiras onde ficavam armazenados os materiais. Além disso, existia a área de trabalho do almoxarife. Geralmente eram abrigados no almoxarifado aqueles materiais que exigiam maior cuidado e controle, como conexões hidráulicas e elétricas, metais, acabamentos, etc., além de ferramentas e equipamentos. Os galpões eram pequenos, uma vez que as construtoras optavam por comprar os materiais aos poucos, de acordo com o andamento da obra, evitando assim a necessidade de grandes estoques.

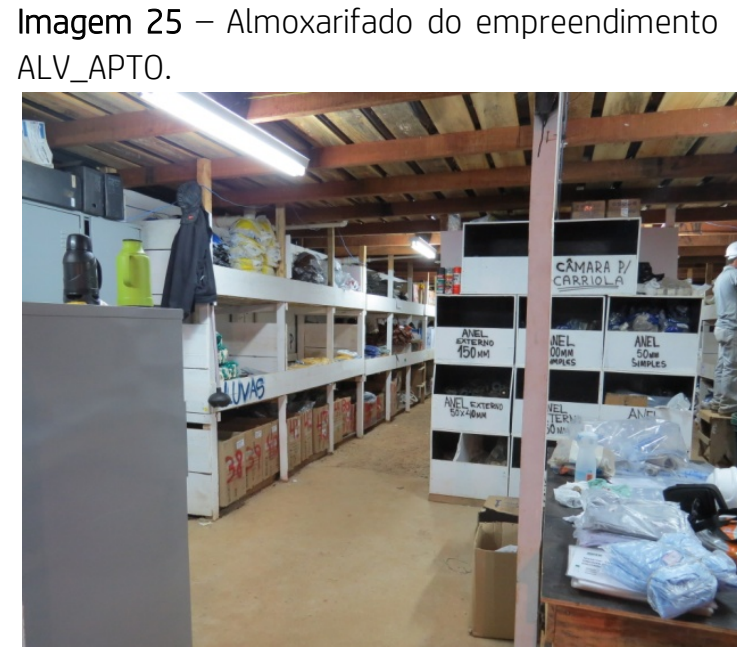

FONTE: Acervo da autora, 2013.
Imagem 26 - Almoxarifado do empreendimento PC_CASA_2.

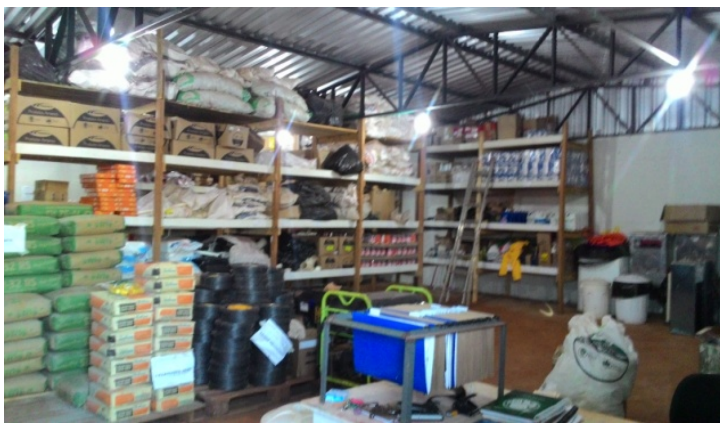

FONTE: Acervo da autora, 2016.

Existiam nos canteiros alguns barracos fechados e contêineres que serviam para estocagem de materiais de maior volume que precisavam permanecer trancados, como por exemplo, sacos de cimento e louças sanitárias. Essas instalações não eram fixas durante toda a obra, as construtoras construíam ou alugavam de acordo com a necessidade de cada período. 
Além de todas essas instalações, todos os canteiros contavam com uma ou mais portarias. Em algumas obras, a entrada dos operários era separada da entrada dos funcionários técnicos ou até mesmo da entrada de materiais e insumos. 0 controle era realizado por equipes terceirizadas, manualmente.

\section{A infra $360^{\circ}$}

Outra questão bastante pertinente em relação ao planejamento do canteiro de obras é a infraestrutura do terreno, que inclui sistema viário, sistema de água e esgoto, calçadas e até áreas de grama. É o que uma das empresas construtoras chama internamente de infra 360․ A orientação geral da Empresa Nacional era de que toda a infra $360^{\circ}$ deveria estar concluída preferencialmente antes de se iniciar a construção dos edifícios. Esse cuidado facilita toda a movimentação dentro do canteiro de obras, tanto dos trabalhadores quanto de máquinas, além de melhorar as condições de segurança e a limpeza do canteiro.

No empreendimento PC_APTO_1, toda a 'infra 360ํํ já estava sendo executada logo no início da obra. A pavimentação das vias era realizada parcialmente, com apenas a primeira camada de asfalto, uma capa de $2 \mathrm{~cm}$, que acaba sendo danificada devido ao tráfego de máquinas e caminhões pesados ${ }^{49}$. Ao final da obra, quando não há mais trânsito de grandes máquinas, é executada a segunda capa, definitiva. Toda a circulação interna do canteiro é feita, portanto, nas vias definitivas já com a primeira camada de pavimentação. Assim como no PC_APTO_1, no PC_APTO_2 toda a infraestrutura e a pavimentação das vias também foram executadas previamente.

Já no ALV_APTO, durante o maior período da obra, não havia pavimentação no canteiro. Os eixos de circulação de trabalhadores e máquinas eram apenas regularizados, mas não eram pavimentados. As vias de circulação de caminhões e máquinas foram acomodadas nos espaços entre os edifícios e não necessariamente se sobrepunham aos locais onde seriam pavimentadas as ruas do empreendimento.

490 engenheiro explicou, por exemplo, que a máquina de hélice contínua utilizada para a execução das estacas pesava 60 toneladas, o que significa que a pavimentação acaba sendo muito agredida durante a obra. Por isso, é necessário refazer antes da entrega do empreendimento. 
O preço da Infra $360^{\circ}$ estava muito caro no início da obra, então a pavimentação foi executada em uma etapa avançada da construção. Este fator gerou alguns problemas no andamento da obra, justamente devido a um período de chuvas. Uma consideração necessária, todavia, é que a obra do ALV_APTO é de período anterior e é possível que a construtora tenha se tornado mais rigorosa com essa questão recentemente.

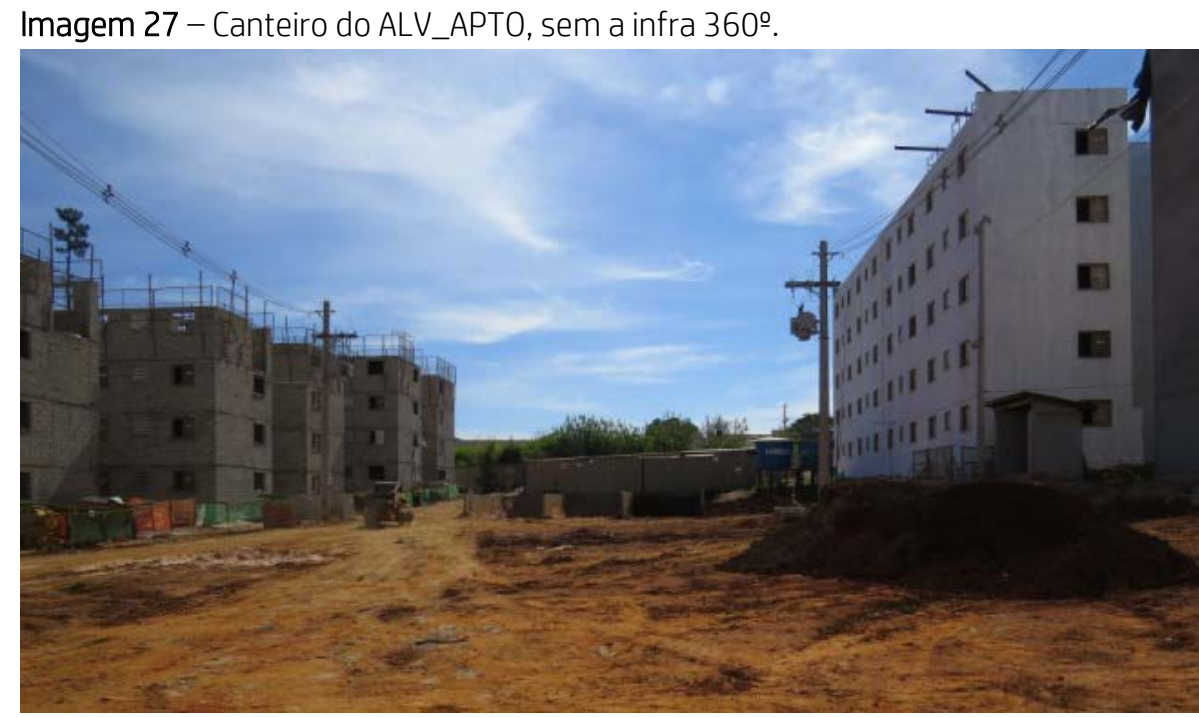

FONTE: Acervo da autora, 2013.

Imagem 28 - Canteiro do PC_APTO_1, com a infra 360․

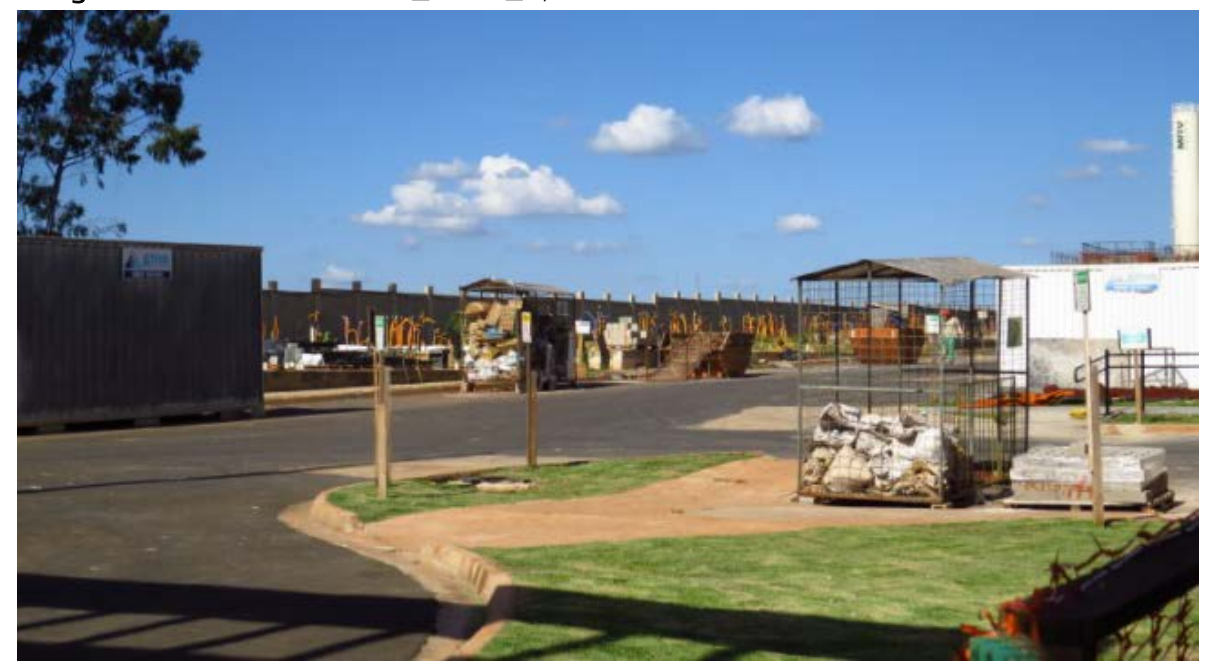

FONTE: Acervo da autora, 2017.

Nos outros dois empreendimentos, da Regional, esta orientação também existia. Desde o início da obra do PC_CASA_1 todas as vias de trânsito de veículos já estavam regularizadas e pavimentadas. Deste modo, o acesso de caminhões, máquinas e carros era facilitado por todo o canteiro. A circulação dentro do canteiro, portanto, 
seguia os trajetos do próprio empreendimento, uma vez que todas as vias já estavam prontas. Do mesmo modo, a circulação no canteiro do PC_CASA_2 foi pensada a partir dos eixos de circulação do próprio empreendimento. A regularização das vias já havia sido executada, porém não existia qualquer tipo de pavimentação ou de calçadas. Todo o trânsito de máquinas e caminhões, portanto, era realizado em vias não pavimentadas.

Em uma conversa, o engenheiro do PC_CASA_2 afirmou que o ideal era que a obra fosse executada já com a infraestrutura viária finalizada, porque facilitaria o trânsito dos caminhões e máquinas e evitaria transtornos em época de chuva. A construtora, entretanto, teve algumas dificuldades nessa obra com o Departamento de água e esgoto (DAEE) do município. Durante a execução do sistema de água - que é o mais profundo - e drenagem, o DAEE não permitiu que a construtora terminasse o serviço de determinado setor, antes de resolver um problema em uma das ruas. Entretanto, a Caixa Econômica Federal (CEF) não autorizou a liberação de recursos para este serviço naquele momento. 0 resultado foi que a Regional optou por aguardar $\mathrm{o}$ pagamento da CEF e, por este motivo, ainda não havia finalizado o sistema de esgoto e drenagem. Por consequência, a pavimentação asfáltica também não podia ser executada, como mostra a Imagem 30.

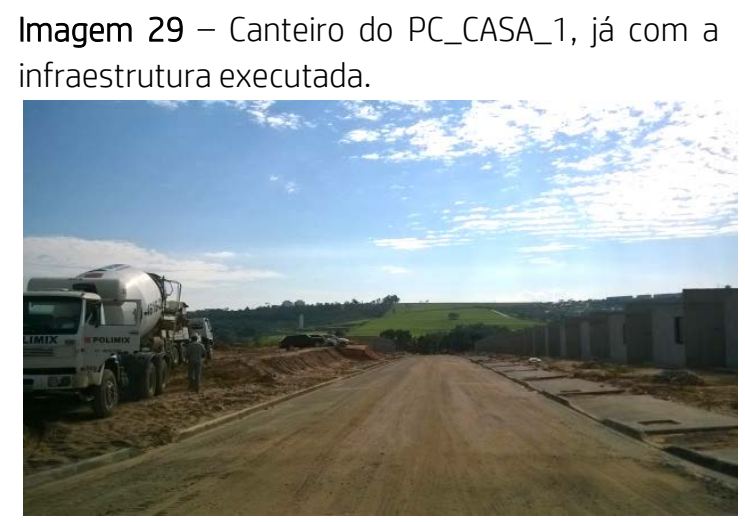

FONTE: Acervo da autora, 2015.

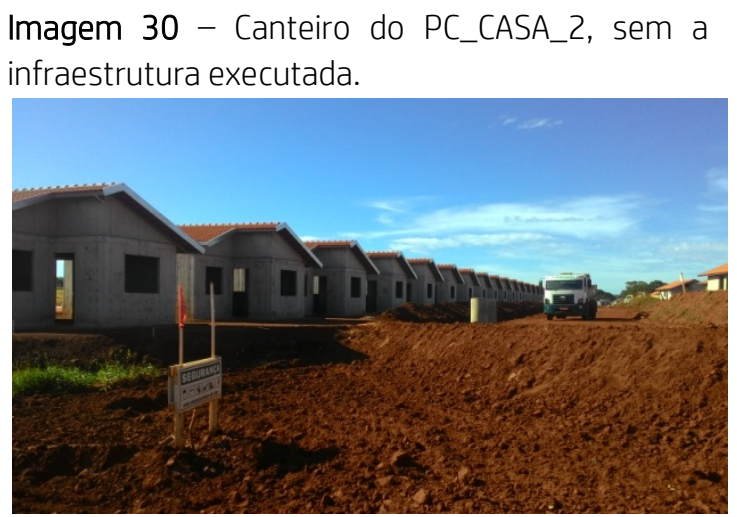

FONTE: Acervo da autora, 2016.

Fatores externos, portanto, por vezes acabam interferindo no planejamento das empresas, como foi o caso do problema com o DAEE em Araraquara. A execução de toda a infraestrutura do terreno antes mesmo do início da construção das 
edificações demonstra que as empresas compreendem o canteiro como o suporte da produção e, como tal, ele deve facilitar todos os processos executivos.

\section{A equação dos fluxos de materiais: logística}

Recuperando o conceito trabalhado no capítulo anterior, podemos entender que a 'logística' se traduz nas atividades de planejamento e controle dos fluxos de materiais, insumos e equipamentos dentro do processo produtivo. A questão principal dentro desta equação é justamente buscar um equilíbrio entre esses fluxos. Prever quais materiais e em quais quantidades serão armazenados no canteiro e em que período e, além disso, controlar sua utilização para evitar desperdícios e perdas. Nas obras visitadas foi bastante visível que a logística tinha papel central dentro do processo produtivo.

Nas primeiras etapas da obra do ALV_APTO havia muitos espaços livres no canteiro, onde seriam posteriormente construídos o segundo e o terceiro módulos. Estes espaços eram utilizados para a estocagem de diversos materiais, como blocos de alvenaria estrutural, conduítes, manilhas, agregados, etc. À medida que os edifícios eram construídos, assim como a parte de infraestrutura e pavimentação, os espaços vazios foram ficando escassos, e os materiais passaram a ser armazenados também fora da área fechada do canteiro. Os agregados - areia e brita - eram geralmente armazenados próximos às bases de produção de argamassa e concreto. 0 madeiramento utilizado para fôrmas também ficava no próprio canteiro, assim como as peças dos andaimes e pallets. 0 entulho também era depositado na obra, em caçambas ou no chão, durante apenas um ou dois dias, depois era recolhido pela empresa responsável. No almoxarifado eram estocadas as peças menores, como peças de elétrica e hidráulica. Os materiais maiores deveriam ser guardados em locais cobertos e trancados, contudo apenas o cimento estava armazenado em contêiner fechado. Segundo a auxiliar da obra, nem sempre era possível armazenar dessa maneira. As mangueiras e conduítes, por exemplo, estavam estocados no próprio canteiro, sem estarem trancados ou cobertos. Os canos de PVC também ficavam armazenados fora de contêineres, porém trancados. As ferragens eram armazenadas em áreas abertas, a certa distância do solo, para evitar corrosão. 
Também estavam armazenados no canteiro blocos cerâmicos, blocos de alvenaria estrutural e pedras de ardósia para as escadas e pingadeiras.

Imagem 31 - Armazenagem de materiais no ALV_APTO.
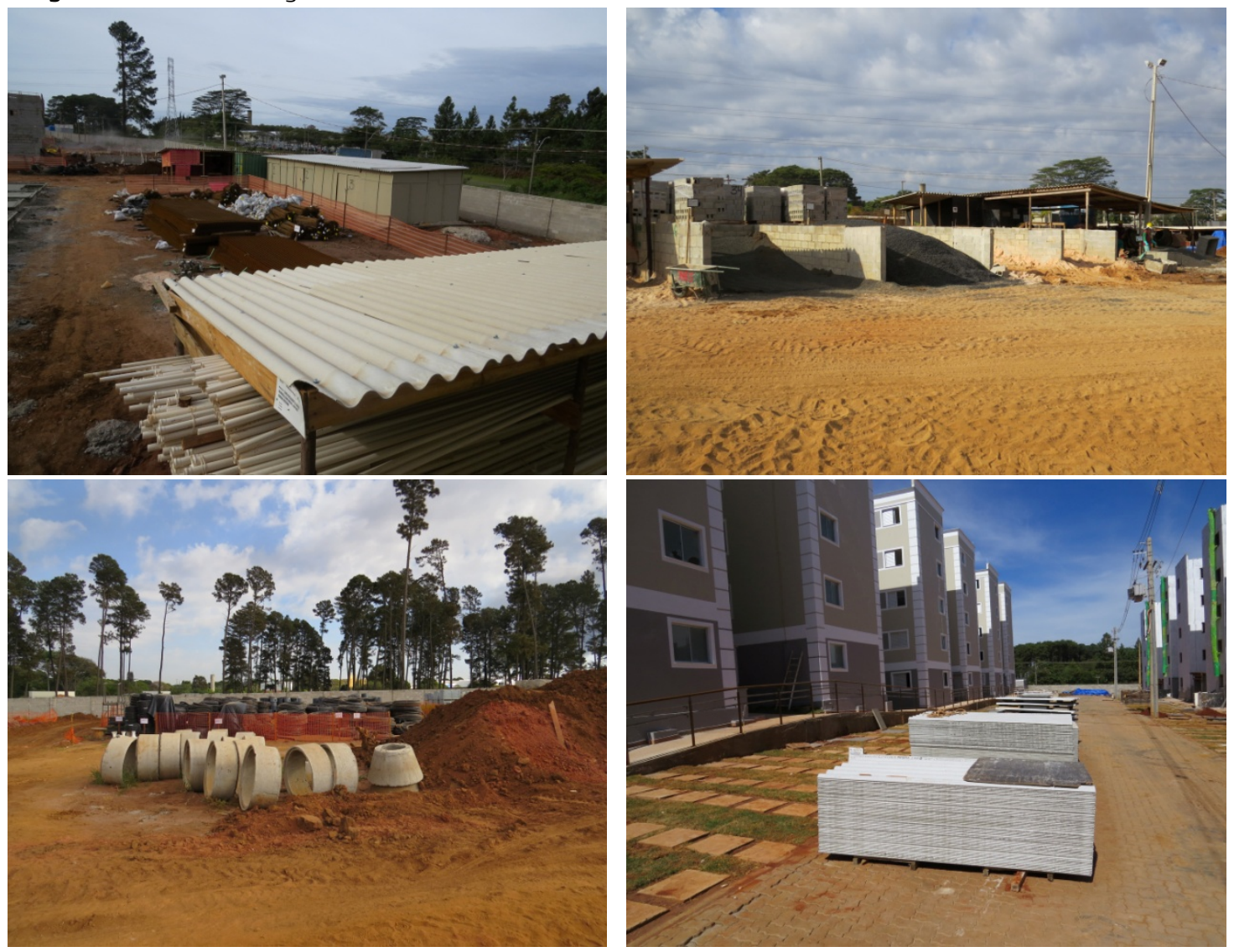

FONTE: Acervo da autora, 2013.

Nas outras duas obras da Empresa Nacional, a armazenagem dos materiais era semelhante. Existiam alguns contêineres e pequenos galpões para armazenamento e estoque de materiais que precisavam ficar trancados. Outros materiais, de maior porte ou de baixo valor, ficavam geralmente acomodados no próprio canteiro de obras, como por exemplo, telhas, blocos de concreto/cerâmica, ferragens e agregados. Alguns materiais e componentes que chegavam à obra e que seriam utilizados em pouco tempo também ficavam, por vezes, armazenados no próprio canteiro. Existiam também diversas caçambas de entulho distribuídas pelo canteiro e áreas provisórias para descarte de materiais. 

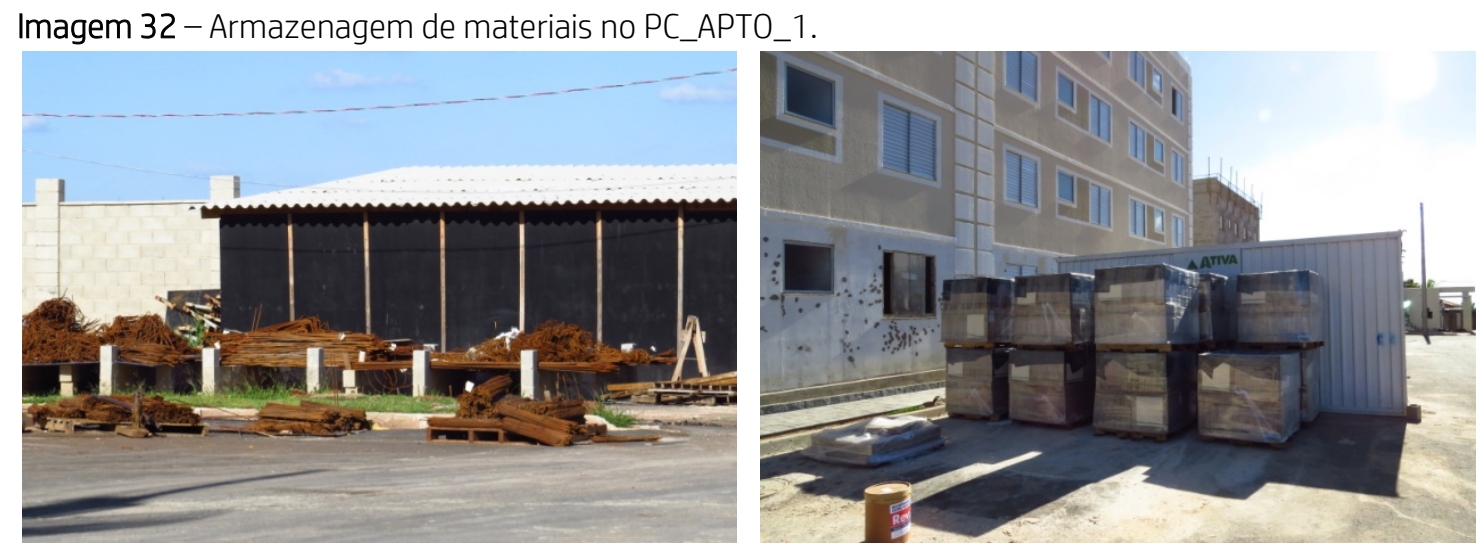

FONTE: Acervo da autora, 2016.
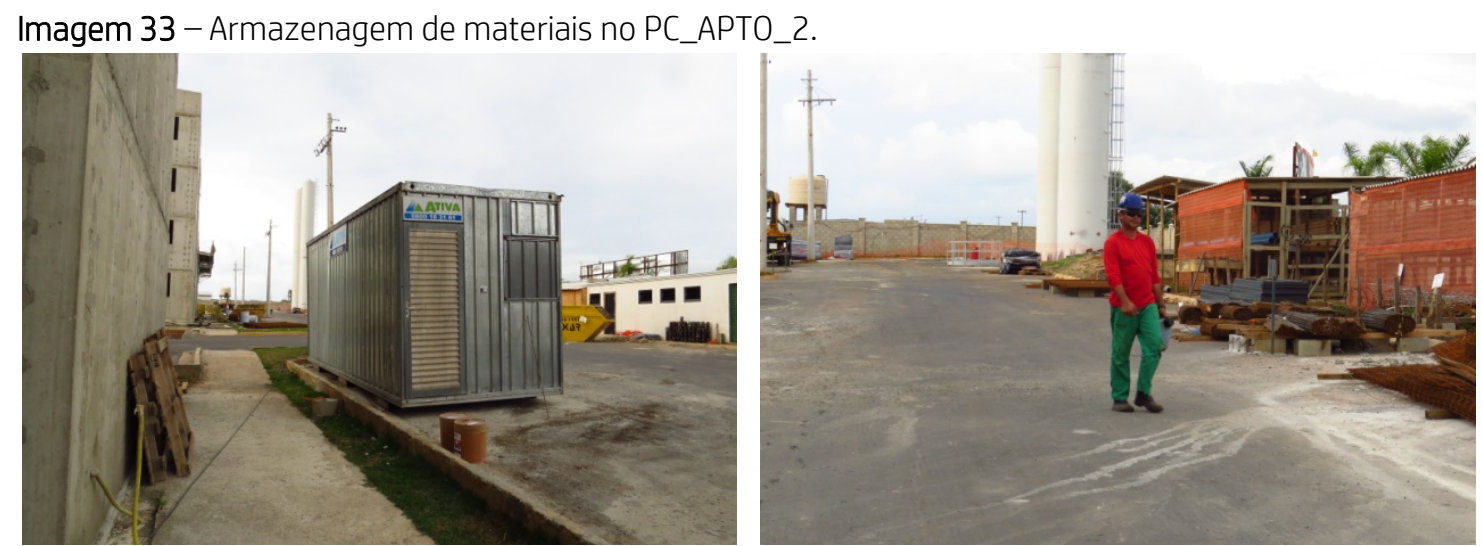

FONTE: Acervo da autora, 2016.

Apenas o ALV_APTO se tratava de um empreendimento executado em alvenaria estrutural. O PC_APTO_1 e o PC_APTO_2 estavam sendo construídos com paredes de concreto. Esses dois sistemas construtivos acabam gerando resultados distintos em relação aos espaços de armazenagem no canteiro.

Obras executadas em alvenaria estrutural pressupõem um grande espaço para estocagem dos blocos de concreto. No caso da Nacional, as compras de materiais podem ser realizadas duas vezes por mês através do sistema informatizado da empresa. Isso significa que durante a fase de elevação da alvenaria, era necessário que os blocos armazenados no canteiro fossem suficientes para este intervalo de tempo. 0 resultado era que grande parte das áreas não edificadas do canteiro servia para armazenagem de enormes quantidades de blocos de concreto (Imagem 34). No início da obra, isso não era exatamente um problema, uma vez que poucos edifícios estavam sendo construídos e havia bastante espaço para o estoque. Na medida em que a construção foi avançando, estes espaços foram ficando escassos, e o canteiro, 
cada vez mais apertado. Diversas etapas estavam ocorrendo concomitantemente, então além dos blocos ainda existiam no canteiro pisos, azulejos, canos de PVC, telhas. A solução encontrada pela construtora foi utilizar uma área do próprio terreno fora do tapume que delimitava o canteiro para estocar os blocos estruturais.

Imagem 34 - Armazenagem de blocos de concreto no ALV_APTO.

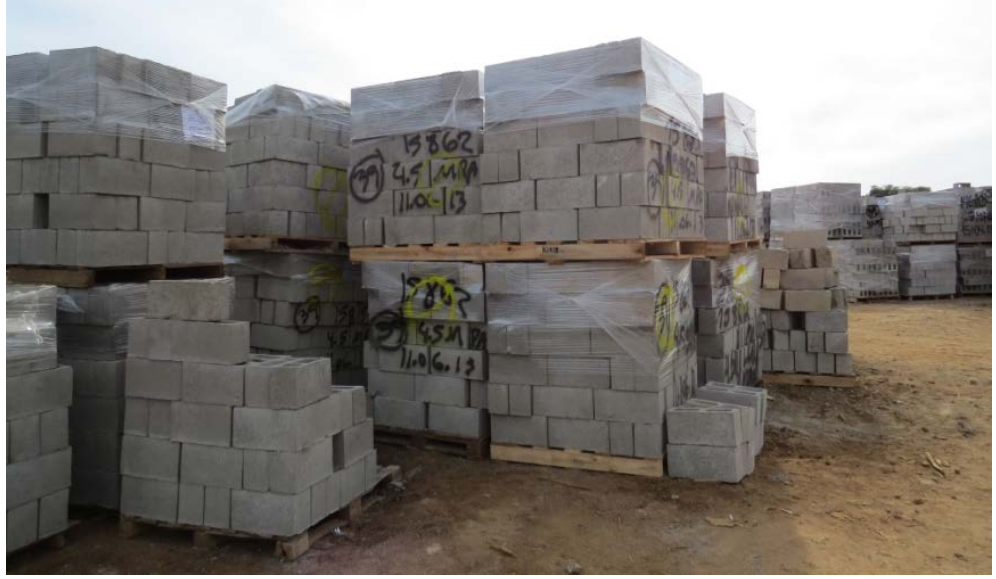

FONTE: Acervo da autora, 2013.

No caso do sistema construtivo executado com paredes de concreto esta questão de estocagem é bastante diminuída. 0 processo basicamente se resume à montagem das formas e depois à concretagem, feita com caminhão betoneira. As fôrmas são montadas e, depois da concretagem, imediatamente desmontadas e remontadas na próxima casa. 0 transporte das formas é realizado manualmente, sem auxílio de máquinas, uma vez que as distâncias percorridas são pequenas. Em alguns casos, apenas as armaduras eram içadas com auxílio de um 'munck'. Os outros materiais, como pisos, azulejos, louças, etc. continuam presentes, e precisam ser estocados quando chegam ao canteiro, porém não representam tanto volume quanto os blocos de concreto. Além disso, para a elevação da alvenaria é necessário produzir no canteiro uma quantidade expressiva de argamassa de assentamento, o que por sua vez, implica na armazenagem de agregados.

As obras da Empresa Nacional apresentavam diferenças nos sistemas construtivos, mas eram todas obras de edifícios de apartamentos. Uma questão a ser resolvida é o transporte vertical de materiais e insumos. Blocos de concreto, pisos, azulejos, louças e outros materiais tinham que ser transportados a seus respectivos andares. Trata-se de materiais pesados, de grande volume. No caso do ALV_APTO, o 
transporte vertical era realizado com uma 'Skytrack', uma espécie de empilhadeira de grande porte que transporta os materiais do chão até o topo da construção. Esses materiais precisavam estar em 'pallets' para que pudessem ser içados. Além do transporte vertical, era necessário transportar esses materiais dentro do canteiro de obras, o que podemos chamar de transporte horizontal. Já nas obras de casas térreas, havia menor preocupação com o transporte vertical dos materiais, evidentemente.

No ALV_APTO, além da 'Skytrack', era utilizado o caminhão 'Munck' para transporte horizontal, um 'bobcat' para limpeza do terreno e terraplanagem e também um guindaste para içamento das lajes pré-moldadas.

Imagem 35 - "Munck" utilizado na obra do ALV_APTO.

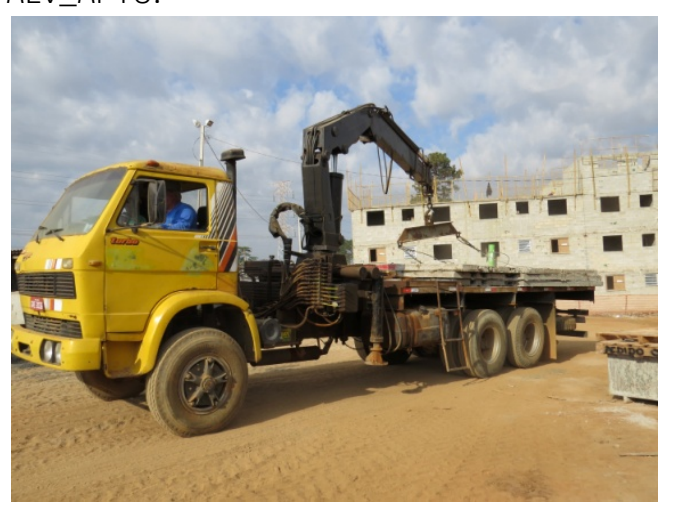

Imagem 37 - "Bobcat" utilizado na obra do ALV_APTO.

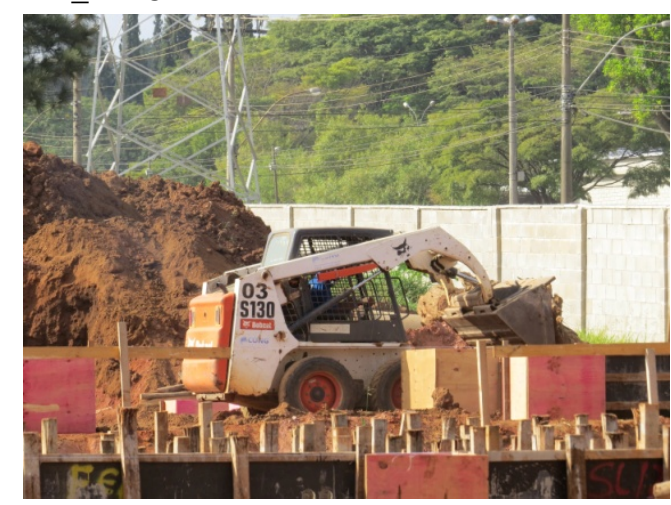

FONTE: Acervo da autora, 2013.
Imagem 36 - Guindaste utilizado na obra do ALV_APTO.

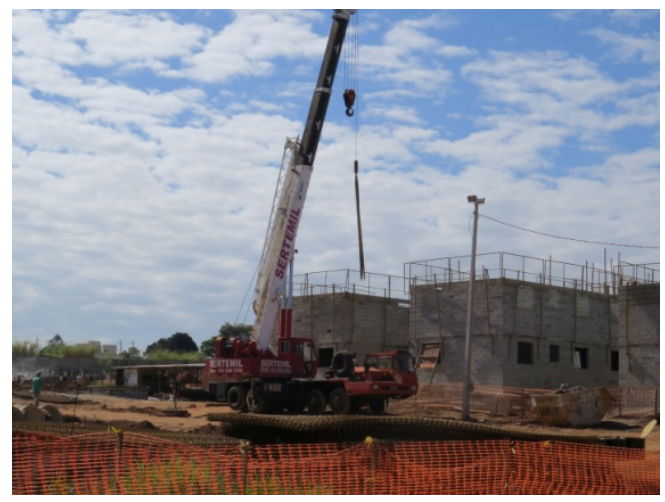

Imagem 38 - "Skytrack" utilizada na obra do ALV_APTO.

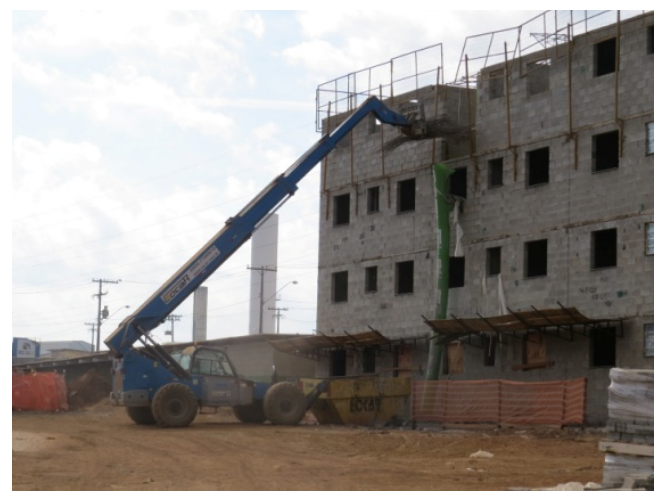


É possível perceber que as empresas dedicam grande esforço no controle sobre o fluxo de materiais. A questão dos suprimentos é uma das principais aplicações da logística dentro da produção da construção de edificações.

"A principal característica da logística aplicada à ICCSE é a ênfase no suprimento de materiais e no fornecimento, no momento adequado, dos insumos necessários a cada atividade. Este é um tradicional fator de interrupção dos processos de trabalho no canteiro, quando não está bem equacionado". (VILLELA, 2007, p. 170).

No canteiro de obras de um empreendimento habitacional coexistem inúmeros processos produtivos, que utilizam distintos materiais e equipamentos. Como já ressaltamos no início do capítulo, cada nova etapa é executada sobre aquilo que foi executado na etapa anterior e deste modo, é preciso haver precisão no controle e no fluxo de todos os insumos necessários, para que a produtividade não seja prejudicada.

\subsection{Instrumento de prescrição}

O processo produtivo dentro do canteiro de obras depende de inúmeros gestos repetidos exaustivamente por um grande número de trabalhadores. Cada serviço tem seu próprio modo de execução e, nos casos analisados, o trabalhador é a figura central do processo.

No intuito de padronizar os gestos dos trabalhadores e, consequentemente, os processos de execução de suas obras, a Empresa Nacional desenvolveu um instrumento de prescrição para ser utilizado dentro dos canteiros. Essa padronização procura diminuir os de erros de execução, evitar retrabalhos e controlar o consumo de materiais.

Os "Procedimentos de Execução e Serviço", chamados dentro das obras de PES, são documentos elaborados pela própria empresa para prescrever todos os processos de execução que ocorrem nas obras da construtora. Atualmente os PES se referem a um conjunto de 49 cartilhas que apresentam instruções detalhadas para seus respectivos processos de execução. Geralmente os PES's seguem a seguinte estrutura: documentos de referência; materiais, equipamentos e ferramentas; método executivo. 
Os documentos de referência são, por exemplo, instruções dos fabricantes, projeto executivo, projeto arquitetônico, outras instruções da construtora, etc. No item 'materiais, equipamentos e ferramentas' é discriminado detalhadamente o que deve ser utilizado na execução da atividade. Por exemplo, no "PES 13 - PISO CERÂMICO, PEDRAS E REJUNTE”, o primeiro material citado é justamente a peça cerâmica. Finalmente, no item 'método executivo' estão as instruções para a realização do serviço. Geralmente este item é iniciado com o subitem 'Condições e recomendações para início do serviço'. Depois é apresentado o passo a passo do respectivo processo de execução, como se fosse uma receita de bolo. São colocadas também ilustrações, fotos e esquemas que auxiliam no entendimento do modo de execução.

Os PES frequentemente sofrem modificações, como acréscimo, exclusão ou alteração de itens, uma vez que os processos de execução estão em constante mudança. Por exemplo, se a empresa percebe que determinada tarefa pode ser executada de um modo mais eficiente, ou se um fornecedor modifica alguma instrução para utilização de seu produto, os respectivos PES devem ser modificados e adequados. A seguir, os PES utilizados nas obras da construtora. 
Quadro 3 - Procedimentos de Execução e Serviços (PES).

\begin{tabular}{|c|c|c|c|}
\hline $\begin{array}{l}\text { P.E.S. } \\
01\end{array}$ & $\begin{array}{l}\text { Compactação e regularização de terreno } \\
\text { para execução de piso pobre }\end{array}$ & $\begin{array}{l}\text { P.E.S. } \\
27\end{array}$ & Execução de forro de gesso \\
\hline $\begin{array}{l}\text { P.E.S. } \\
02\end{array}$ & Locação de obra & $\begin{array}{l}\text { P.E.S. } \\
28\end{array}$ & $\begin{array}{l}\text { Assentamento de louças, bancadas, } \\
\text { tanques e metais }\end{array}$ \\
\hline $\begin{array}{l}\text { P.E.S. } \\
03\end{array}$ & $\begin{array}{l}\text { Execução de fundação em tubulão a céu } \\
\text { aberto }\end{array}$ & $\begin{array}{l}\text { P.E.S. } \\
29\end{array}$ & Instalações elétricas \\
\hline $\begin{array}{l}\text { P.E.S. } \\
04\end{array}$ & $\begin{array}{l}\text { Formas de madeira para estrutura de } \\
\text { concreto }\end{array}$ & $\begin{array}{l}\text { P.E.S. } \\
30\end{array}$ & Instalações hidrossanitárias \\
\hline $\begin{array}{l}\text { P.E.S. } \\
05\end{array}$ & $\begin{array}{l}\text { Montagem de armadura para estrutura de } \\
\text { concreto }\end{array}$ & $\begin{array}{l}\text { P.E.S. } \\
31\end{array}$ & $\begin{array}{l}\text { Impermeabilização de reservatório de } \\
\text { áreas úmidas e coberturas }\end{array}$ \\
\hline $\begin{array}{l}\text { P.E.S. } \\
06\end{array}$ & Concretagem de peças estruturais & $\begin{array}{l}\text { P.E.S. } \\
32\end{array}$ & $\begin{array}{l}\text { Execução de fundação em estaca pré- } \\
\text { moldada de concreto }\end{array}$ \\
\hline $\begin{array}{l}\text { P.E.S. } \\
07\end{array}$ & Execução de alvenaria estrutural & $\begin{array}{l}\text { P.E.S. } \\
33\end{array}$ & $\begin{array}{l}\text { Execução de fundação em estaca } \\
\text { strauss }\end{array}$ \\
\hline $\begin{array}{l}\text { P.E.S. } \\
08\end{array}$ & $\begin{array}{l}\text { Execução de alvenaria estrutural e } \\
\text { platibanda }\end{array}$ & $\begin{array}{l}\text { P.E.S. } \\
34\end{array}$ & $\begin{array}{l}\text { Tabela geral de traços de argamassa - } \\
\mathrm{BH}\end{array}$ \\
\hline $\begin{array}{l}\text { P.E.S. } \\
08 \mathrm{~A}\end{array}$ & Execução de muro de divisa & $\begin{array}{l}\text { P.E.S. } \\
35\end{array}$ & $\begin{array}{l}\text { Tabela geral de traços de argamassa - } \\
\text { Regional }\end{array}$ \\
\hline $\begin{array}{l}\text { P.E.S. } \\
09\end{array}$ & Gesso em paredes e em teto & $\begin{array}{l}\text { P.E.S. } \\
35 \mathrm{~B}\end{array}$ & $\begin{array}{l}\text { Tabela geral de traços de argamassa - } \\
\text { Torres }\end{array}$ \\
\hline $\begin{array}{l}\text { P.E.S. } \\
10\end{array}$ & Revestimento interno de argamassa & $\begin{array}{l}\text { P.E.S. } \\
36\end{array}$ & $\begin{array}{l}\text { Tabela geral de traços de argamassa - } \\
\text { BH e Regional }\end{array}$ \\
\hline $\begin{array}{l}\text { P.E.S. } \\
11\end{array}$ & Revestimento externo de argamassa & $\begin{array}{l}\text { P.E.S. } \\
37\end{array}$ & Execução de escada \\
\hline $\begin{array}{l}\text { P.E.S. } \\
12\end{array}$ & Execução de contrapiso & $\begin{array}{l}\text { P.E.S. } \\
38\end{array}$ & Execução de fundação em estaca trado \\
\hline $\begin{array}{l}\text { P.E.S. } \\
13\end{array}$ & Piso cerâmico, pedras e rejunte & $\begin{array}{l}\text { P.E.S. } \\
39\end{array}$ & deira \\
\hline $\begin{array}{l}\text { P.E.S. } \\
14\end{array}$ & Pavimentação de áreas externas & $\begin{array}{l}\text { P.E.S. } \\
40\end{array}$ & Laje \\
\hline $\begin{array}{l}\text { P.E.S. } \\
15\end{array}$ & $\begin{array}{l}\text { Cobertura em telhas de fibrocimento ou } \\
\text { cerâmica }\end{array}$ & $\begin{array}{l}\text { P.E.S. } \\
41\end{array}$ & $\begin{array}{l}\text { Execução de fundação em sapatas } \\
\text { isoladas }\end{array}$ \\
\hline $\begin{array}{l}\text { P.E.S. } \\
16\end{array}$ & Colocação de marco metálico e madeira & $\begin{array}{l}\text { P.E.S. } \\
42\end{array}$ & Caixa d'água \\
\hline $\begin{array}{l}\text { P.E.S. } \\
17\end{array}$ & Colocação de porta metálica e madeira & $\begin{array}{l}\text { P.E.S. } \\
43\end{array}$ & Execução de estaca hélice contínua \\
\hline $\begin{array}{l}\text { P.E.S. } \\
18\end{array}$ & Colocação de janela de alumínio & $\begin{array}{l}\text { P.E.S. } \\
44\end{array}$ & Execução de laje pré-moldada içada \\
\hline $\begin{array}{l}\text { P.E.S. } \\
19\end{array}$ & Execução de pintura interna PVA ou acrílica & $\begin{array}{l}\text { P.E.S. } \\
45 \mathrm{~A}\end{array}$ & Parede de concreto \\
\hline $\begin{array}{l}\text { P.E.S. } \\
20\end{array}$ & Pintura externa acrílica ou textura & $\begin{array}{l}\text { P.E.S. } \\
45 \mathrm{~B}\end{array}$ & $\begin{array}{l}\text { Parede de concreto - instalações } \\
\text { elétricas, hidrossanitárias e esgoto }\end{array}$ \\
\hline $\begin{array}{l}\text { P.E.S. } \\
21\end{array}$ & Limpeza fina e grossa da unidade & $\begin{array}{l}\text { P.E.S. } \\
45 \mathrm{C}\end{array}$ & $\begin{array}{l}\text { Parede de concreto - instalação de } \\
\text { batentes, portas e esquadrias }\end{array}$ \\
\hline $\begin{array}{l}\text { P.E.S. } \\
22\end{array}$ & Assentamento de peitoril & $\begin{array}{l}\text { P.E.S. } \\
46\end{array}$ & Arrimos \\
\hline $\begin{array}{l}\text { P.E.S. } \\
23\end{array}$ & Execução de laje pré-moldada & $\begin{array}{l}\text { P.E.S. } \\
47\end{array}$ & Wood frame \\
\hline $\begin{array}{l}\text { P.E.S. } \\
24\end{array}$ & $\begin{array}{l}\text { Assentamento de caixas de esgoto e } \\
\text { passagem }\end{array}$ & $\begin{array}{l}\text { P.E.S. } \\
48\end{array}$ & Norma de desempenho \\
\hline $\begin{array}{l}\text { P.E.S. } \\
25\end{array}$ & $\begin{array}{l}\text { Assentamento de cerâmica em parede } \\
\text { interna }\end{array}$ & $\begin{array}{l}\text { P.E.S. } \\
49\end{array}$ & $\begin{array}{l}\text { Instalação de gás e teste de } \\
\text { estanqueidade }\end{array}$ \\
\hline $\begin{array}{l}\text { P.E.S. } \\
26\end{array}$ & $\begin{array}{l}\text { Assentamento de cerâmica e pedra em } \\
\text { fachada }\end{array}$ & & \\
\hline
\end{tabular}

FONTE: Elaboração própria a partir de informações coletadas nas visitas de campo. 
Nem todos os PES são utilizados em todas as obras da construtora. Evidentemente, se uma obra tem fundação de hélice contínua, por exemplo, os PES's relacionados a outros tipos de fundação não serão utilizados. Uma ponderação necessária, todavia, é que esses 49 documentos servem às obras da construtora em todo o território nacional, o que indica a estratégia de padronização da empresa.

Além dos PES, usualmente eram colocados, dentro do canteiro de obras, quadros de instrução para execução de algumas atividades. Essa é uma estratégia utilizada para garantir que os trabalhadores sigam os padrões de produção exigidos pela construtora. Esses quadros de instrução que ficam dentro do canteiro se apropriam de uma linguagem ainda mais direta, por meio de figuras e algumas informações mais relevantes. Além disso, serviam apenas para a respectiva obra, enquanto os PES continham instruções gerais, para todas as obras da construtora.

Era o caso dos traços de concreto e argamassa, por exemplo. Para instruir os operários a produzirem cada tipo de massa, na obra do ALV_APTO existia um quadro - colocado nas áreas de apoio à produção - contendo todos os traços (Imagem 39).

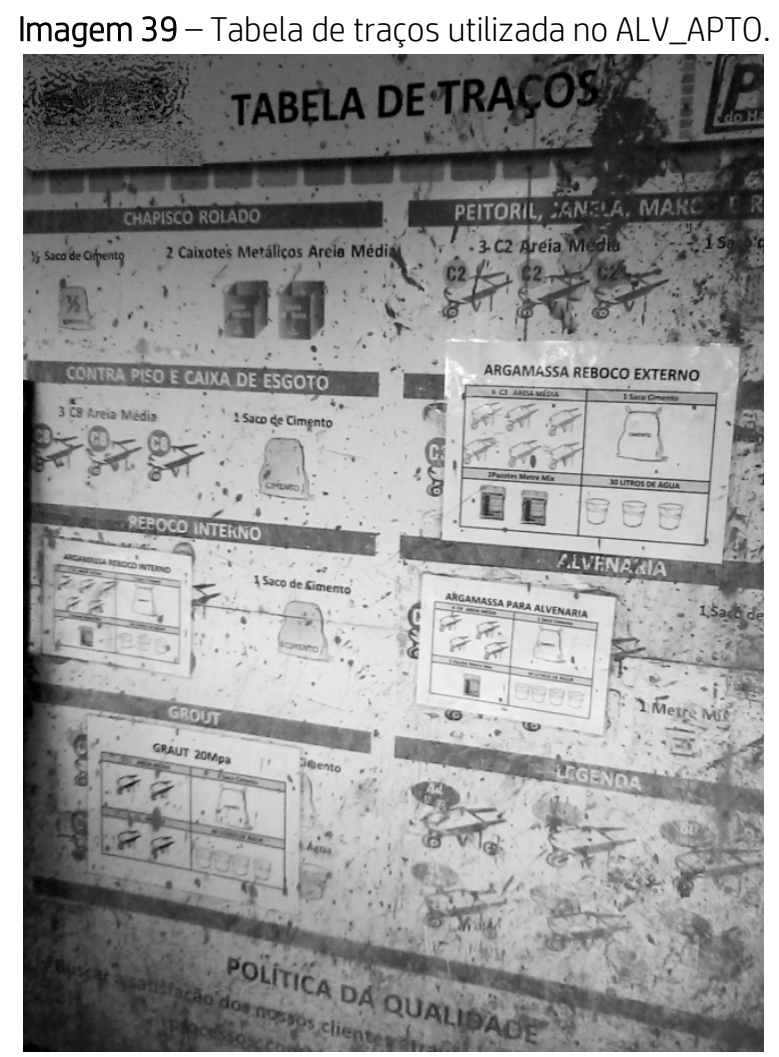

FONTE: Quaglio, 2014. 
Mas então os PES seriam um elo de comunicação entre o aspecto técnico-normativo e o empírico? Projetos executivos e normas técnicas são instrumentos complexos, inacessíveis muitas vezes aos trabalhadores do canteiro. A estratégia de reescrever as informações técnicas a partir de uma linguagem mais dinâmica e simplificada pode representar uma aproximação - pequena que seja - entre o operário e o escritório.

A outra Empresa Regional não utilizava este tipo de instrumento de prescrição. Todas as tarefas eram executadas com base nas normas e nos projetos executivos, mas não havia esse documento intermediário entre escritório e obra.

Teoricamente, o trabalhador deve ter em mãos uma versão impressa do PES relativo ao serviço que ele deverá executar. Em cada via das PES tem um aviso em destaque alertando o trabalhador para que ele confira se a versão que está utilizando é a mais atual. Contudo, na prática, os PES eram geralmente utilizados por responsáveis técnicos, como auxiliares ou mesmo o mestre de obras, que então passavam as instruções aos operários.

\subsection{Preparação, 'kits' prontos e pré-fabricação}

A utilização de componentes industrializados dentro do canteiro de obras foi um marco importante no desenvolvimento da ICCSE. Desde os anos 1980, a indústria de materiais e componentes passou a se apropriar de algumas etapas produtivas antes realizadas no canteiro. Até então, apenas as grandes construtoras tinham acesso a esse tipo de produto. Nos anos 1990, houve um processo de expansão do setor de materiais e componentes, permitindo a incorporação desses elementos também pelas construtoras de menor porte 50 (MOURA, 2011).

\footnotetext{
50 Moura (2011) se utiliza do termo 'industrialização sutil', cunhado por Luiz Henrique Ceotto, referindo-se ao processo de incorporação de componentes industrializados nos canteiros de obras que, apesar de intenso, foi pouco percebido, sutil.
} 
A transferência de etapas da produção do canteiro para o setor de materiais e componentes e a consolidação desse ramo da cadeia produtiva, além de constituir um dos caminhos de desenvolvimento das forças produtivas na construção civil, foi um dos fatores de difusão de tecnologia no setor (MOURA, 2011, p. 129).

Retirar processos de execução de dentro do canteiro de obras ou pelo menos do local final de execução se trata de uma iniciativa que visa aumentar a produtividade a partir de uma estratégia organizacional. Em todas as obras visitadas - sem exceção - existiam iniciativas nesse sentido, seja no processo de preparação de materiais e componentes, na utilização de 'kits' comprados já prontos ou efetivamente na préfabricação de elementos construtivos.

Em relação à produção habitacional, Farah (1992) discrimina três tipos de atividades dentro do processo produtivo: a preparação; a construção propriamente dita; e o suporte a essas atividades. Estão inseridos no primeiro grupo todos os processos que tratam do preparo de materiais, insumos e componentes. A préfabricação, a utilização de componentes prontos e até mesmo a preparação prévia e planejada de materiais e insumos são estratégias que buscam a racionalização do processo produtivo.

Nos empreendimentos observados, essas iniciativas de racionalização estavam muito presentes. Foi possível aferir que as empresas buscavam reduzir justamente a variabilidade de atividades que ocorrem no espaço da edificação e, desse modo, aumentar a produtividade. 0 resultado é a diminuição do número e da variedade das equipes de trabalho dentro do canteiro de obras, e maior controle tanto do trabalho quanto da qualidade dos produtos. Ainda que a preparação de componentes e a préfabricação por vezes sejam realizadas dentro do canteiro de obras, apenas o fato de retirar estas atividades do espaço da edificação já representa ganhos consideráveis de produtividade.

As empresas claramente têm investido nesse tipo de racionalização. Apresentaremos a seguir as estratégias observadas nos canteiros de obras.

\section{Preparação de componentes}

Em um empreendimento habitacional de larga escala, existe uma quantidade considerável de componentes construtivos que precisam ser preparados para a execução das edificações, independentemente do sistema estrutural / construtivo 
utilizado. É preciso, por exemplo, preparar argamassa, cortar ferragens e armaduras, cortar canos e condutores, quebrar blocos, etc. Todas essas atividades podem ser realizadas no local final da execução, ou seja, na própria edificação ou então podem ser previamente planejadas e executadas em um local separado do canteiro de obras.

No caso da obra do ALV_APTO, que foi executada com blocos estruturais de concreto, existia uma pequena cobertura dentro do canteiro com uma bancada onde eram realizados os cortes nos blocos. Na mesma oficina, também eram preparadas as armaduras (Imagem 40). Existiam também nessa obra, algumas bases para a preparação de argamassa de assentamento. Eram pequenos espaços cobertos equipados com betoneiras, algumas ferramentas como enxada e pá e próximos às áreas de armazenagem de agregados (Imagem 42).

No PC_CASA_1, existia uma base para preparação dos 'kits' hidráulicos. 0 material era comprado normalmente, mas dentro do canteiro, um funcionário era responsável por cortar, separar e montar um 'kit' para cada unidade. Existia uma instalação que servia apenas a essa atividade. Era uma área coberta, próxima ao almoxarifado e equipada com uma bancada e algumas ferramentas (Imagem 41). Do mesmo modo, no PC_APTO_2, esses kits também foram preparados em uma base de produção no próprio canteiro, por uma equipe com quatro funcionários terceirizados.

Atualmente, nos empreendimentos executados em paredes de concreto pela Empresa Nacional está sendo utilizada uma estratégia parecida para a montagem das telas de armadura das paredes. Tanto na obra do PC_APTO_1 quanto na do PC_APTO_2, as telas das armaduras eram preparadas no chão, a partir de um gabarito. Em seguida, os eletrodutos eram amarrados nas telas, com auxílio de espaçadores. Finalmente, o conjunto era içado e posicionado no local final. 
Imagem 40 - Base de preparação de blocos de alvenaria e armaduras do ALV_APTO.

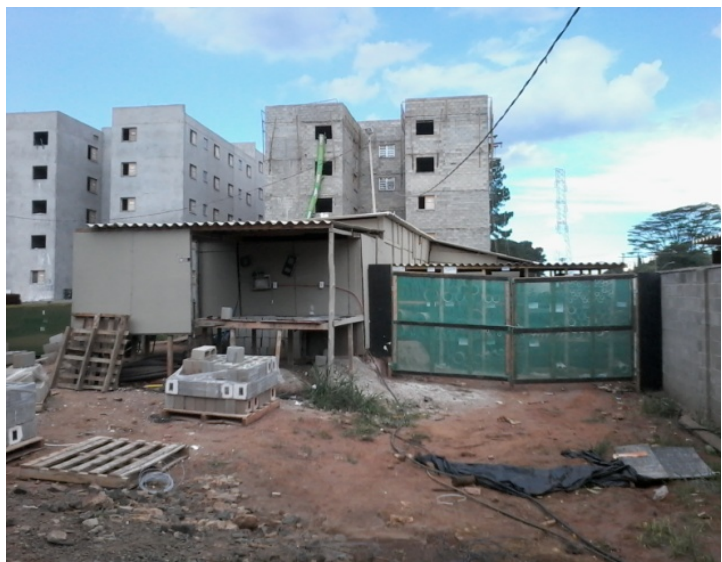

FONTE: Acervo da autora, 2013.
Imagem 41 - Base de preparação dos kits hidráulicos do PC_CASA_1.

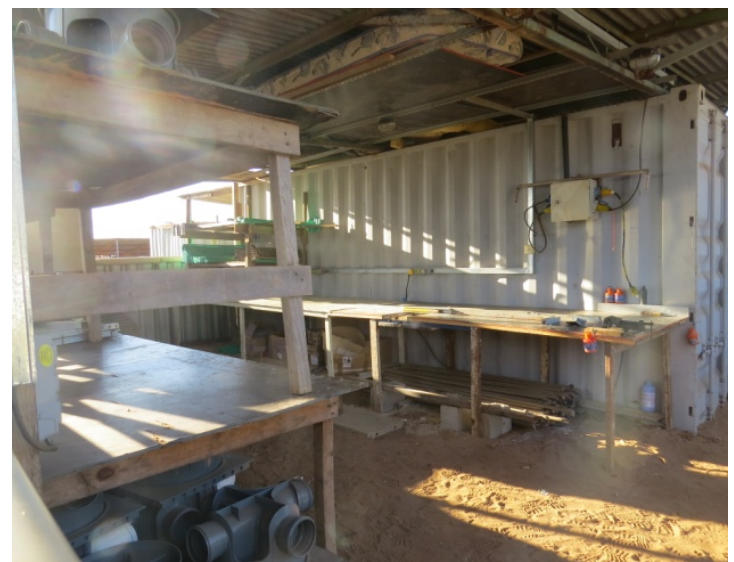

FONTE: Acervo da autora, 2015.

Imagem 42 - Base de preparação de concreto e argamassa do ALV_APTO.

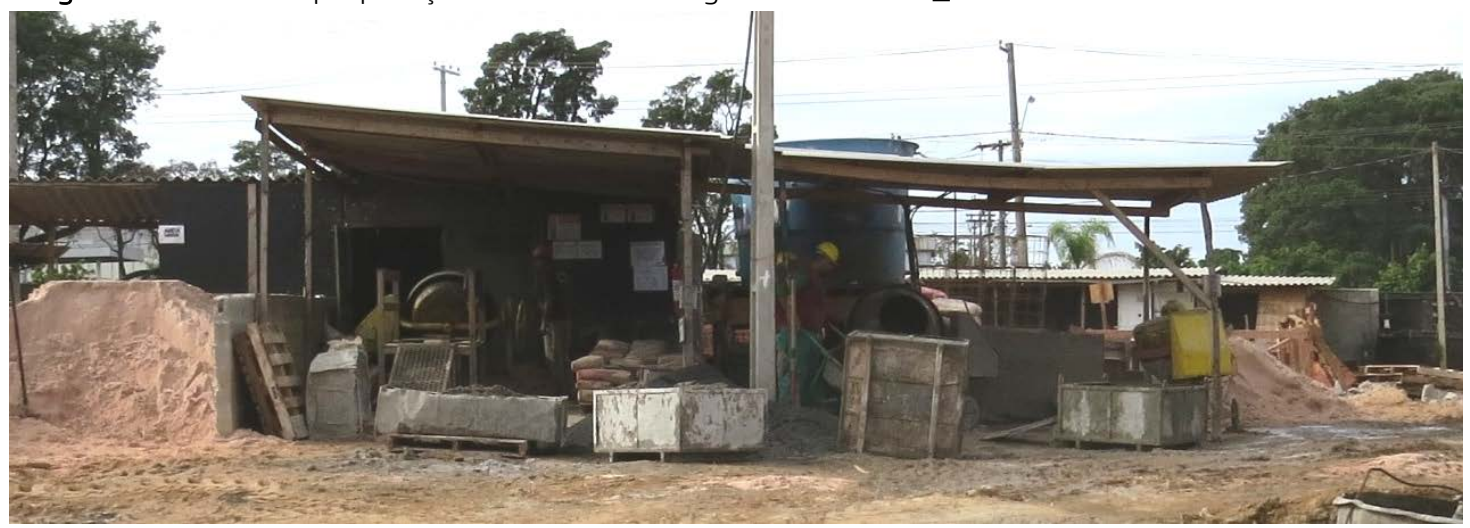

FONTE: Acervo da autora, 2013.

\section{'Kits' prontos}

Ao invés de preparar os componentes no canteiro, em algumas situações as empresas construtoras optavam por já comprar os 'kits' prontos por empresas especializadas. Era uma estratégia bastante comum para as instalações elétricas e hidráulicas, sistema de cobertura e portas e janelas.

Ao contrário do PC_APTO_2, na obra do PC_APTO_1 todos os kits hidráulicos já foram comprados prontos. Esses kits são conjuntos de tubos e conexões já montados e, em certos casos, soldados em chassis, que são diretamente instalados no local e conectados à rede. Os kits comprados prontos apresentam maior garantia de qualidade, por terem maior controle no processo de produção. Segundo o Anuário 
da Construção de 2013, a utilização dos kits prontos traz rapidez na instalação, redução dos resíduos e de perdas, facilidade no controle de estoque e na logística do canteiro. Mesmo os kits preparados no próprio canteiro já apresentam vantagens em relação à produtividade, se comparados com a instalação executada no local final. Entretanto, os kits que chegam prontos eliminam a necessidade de uma base para montagem no canteiro.

Existem diversos tipos de kits hidráulicos. Os mais comuns são o 'kit chuveiro'; os 'ramais de esgoto'; os 'kits isométricos'; a 'caixa de hidrante com coletor e conexões'; o 'kit chassi para lavatórios, tanques e cubas de cozinha'. Nas obras de casas térreas, as instalações hidráulicas eram bastante simples e reduzidas. Foram utilizados kits prontos de chuveiro (Imagem 43), e, além disso, apenas existia a tubulação direta da pia da cozinha, do banheiro e do tanque da lavanderia. Já nas obras de apartamentos, as instalações hidráulicas eram mais complexas, e foi possível observar o kit do chuveiro (Imagem 44), o kit dos ramais de esgoto - que ficavam sob as lajes dos banheiros e depois eram escondidos com forro de gesso ou PVC (Imagem 44), - e também o kit de caixa de hidrante com coletor e conexões. Todos os kits de chuveiro eram instalados externamente às paredes e em seguida era executada uma vedação com placas de gesso.

Já os kits elétricos chegavam prontos em todas as obras visitadas (Imagem 45). Eram compostos pelos eletrodutos, fios e as caixinhas e cada conjunto de materiais era exatamente o que seria utilizado em uma casa ou apartamento. Nas obras do PC_APTO_1 e do PC_APTO_2, as instalações elétricas eram fornecidas pela empresa Âmbar que, inclusive mantinha um estagiário próprio dentro da obra para acompanhar os processos de instalação dos kits.

Os kits elétricos ficam sempre presos às telas de armaduras e os fios são passados antes mesmo da concretagem das paredes. Segundo o engenheiro do PC_CASA_1, passar a fiação antes da concretagem evita furtos dos fios, diferentemente do que ocorre no processo convencional, em que os fios são passados aos poucos e ficam soltos até o final da instalação. 
Imagem 43 - Kit do chuveiro já instalado no PC_CASA_1.

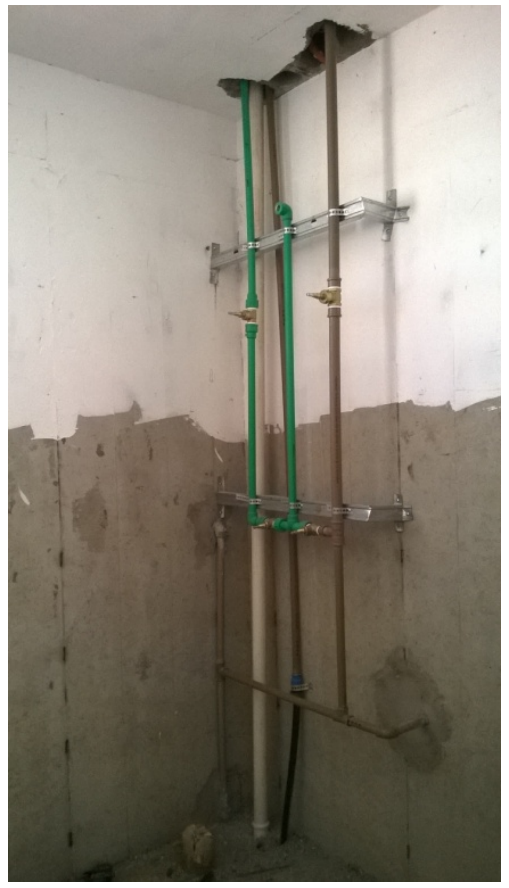

FONTE: Acervo da autora, 2015.

Imagem 45 - Kits elétricos no PC_APTO_2.

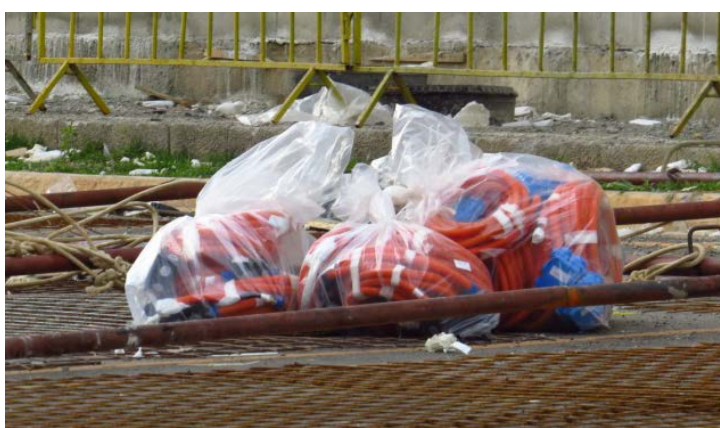

FONTE: Acervo da autora, 2017.
Imagem 44 - Kit do chuveiro e ramais de esgoto já instalados no PC_APTO_1.

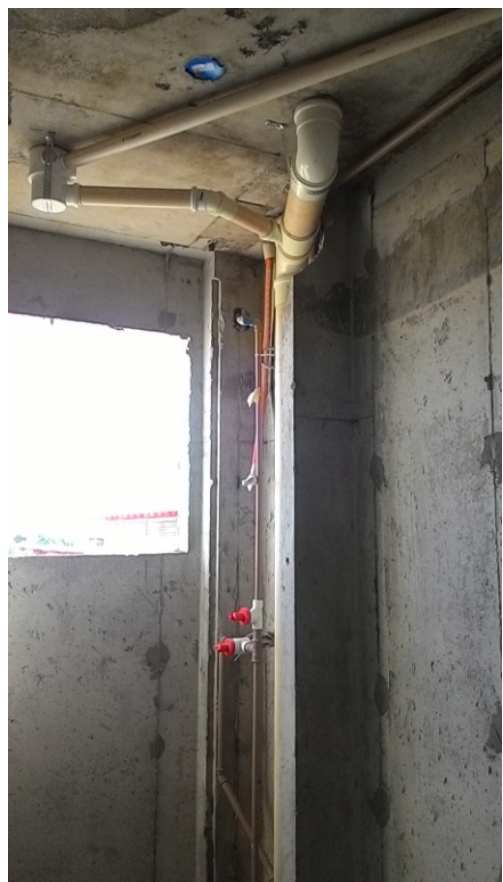

FONTE: Acervo da autora, 2017.

Imagem 46 - Detalhe dos kits elétricos já presos à armadura no PC_CASA_2.

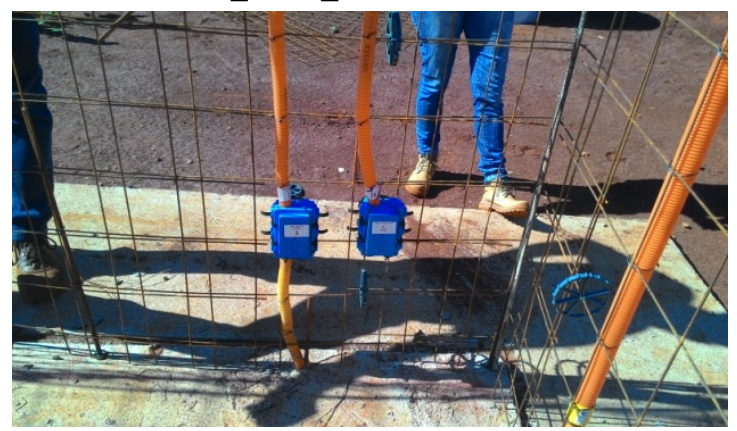

FONTE: Acervo da autora, 2017.

Nos empreendimentos de casas, além dos kits de hidráulica e elétrica, eram utilizados também kits da estrutura da cobertura (Imagem 47). A estrutura da cobertura era de aço galvanizado que, segundo o engenheiro do PC_CASA_1, é mais vantajosa que a estrutura de madeira. Isso porque a estrutura metálica já vem préfabricada, com tamanho-padrão e sem risco de imperfeições (como acontece com a madeira), o que evita perdas e desperdícios. 0 fornecimento dos kits, entretanto, se difere ligeiramente dos kits hidráulicos e elétricos. Os materiais da cobertura são fornecidos a cada conjunto de casas e não em pacotes individuais. Cada tipo diferente de peça vem em um pacote separado, suficiente para executar 30 
unidades. Ou seja, são entregues conjuntos de pacotes separados por tipo de peça, contendo sempre 30 peças cada. As telhas não fazem parte deste conjunto e são compradas a parte.

Finalmente, outros tipos de componentes que chegam ao canteiro em forma de kits são as portas e janelas. Em todas as obras as construtoras optavam por comprar os conjuntos já completos, e apenas faziam a instalação no local. 0 conjunto porta já chegava com batentes, folha, maçaneta e, quando fosse o caso, vidros. Na obra do PC_APTO_2 este conjunto continha inclusive uma fita amortecedora nos batentes. Do mesmo modo, as janelas já eram fornecidas com batentes, folhas, vidros e trincos. No empreendimento PC_APTO_1, a colocação de portas e janelas era realizada apenas por um trabalhador, subempreitado. As janelas e as portas já vinham inclusive com uma proteção que só era retirada após a pintura das paredes (Imagem 52). Mesmo assim, segundo o encarregado era comum ter janelas danificadas durante a obra, com vidros quebrados, por exemplo.

Imagem 47 - Detalhe da cobertura metálica no PC_CASA_2.

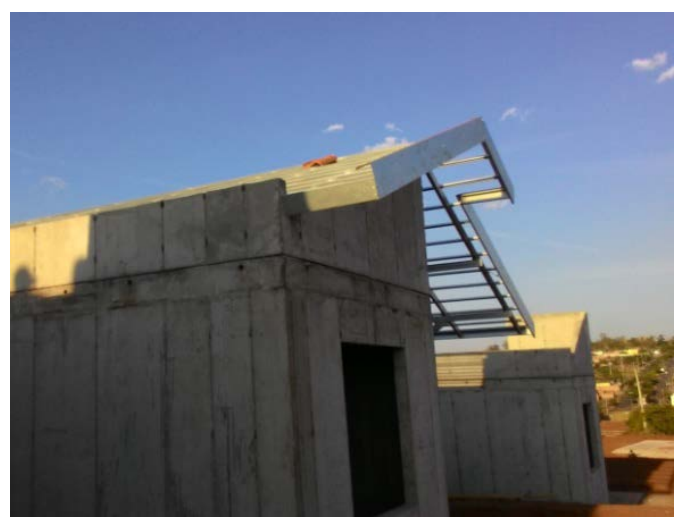

FONTE: Acervo da autora, 2017.
Imagem 48 - Detalhe da cobertura metálica no PC_CASA_1.

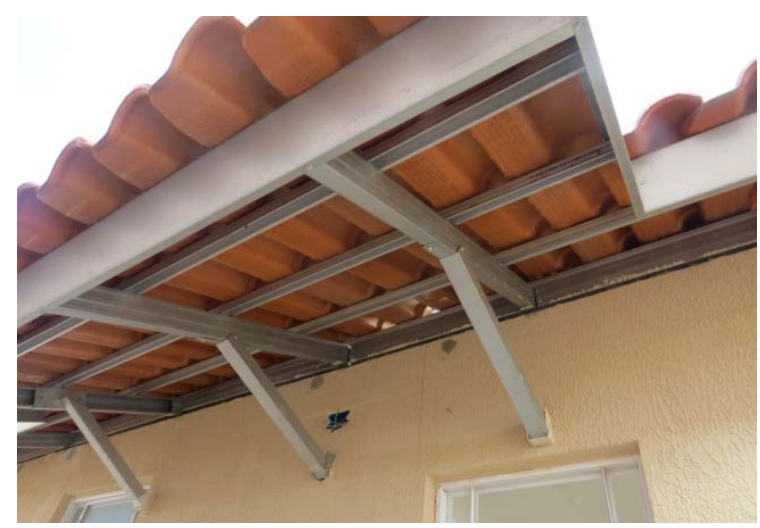

FONTE: Acervo da autora, 2015. 
Imagem 49 - Kit de porta completo do PC_CASA_2.

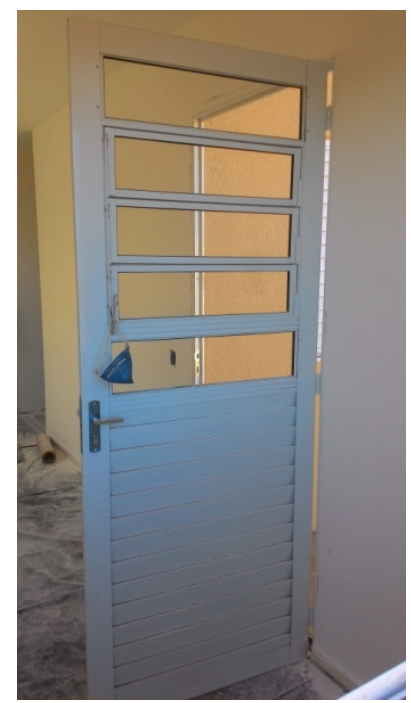

FONTE: Acervo da autora, 2016.

Imagem 51 - Kit de porta completo do PC_APTO_1.

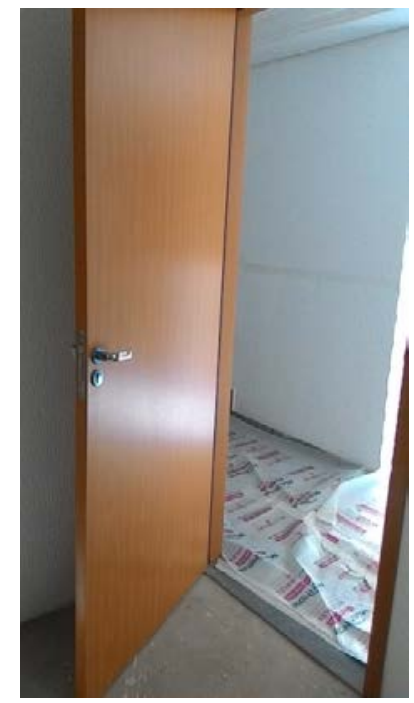

FONTE: Acervo da autora, 2017.
Imagem 50 - Kit de porta e janela completos do PC_CASA_1.

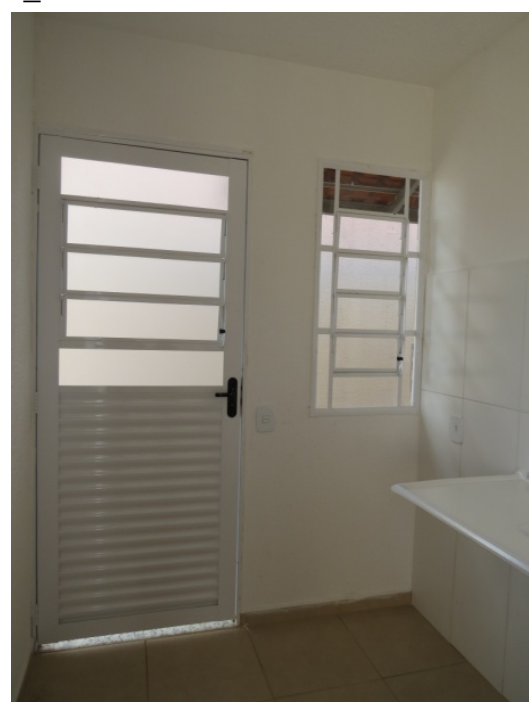

FONTE: Acervo da autora, 2015.

Imagem 52 - Kit de janela completo do PC_APTO_1.

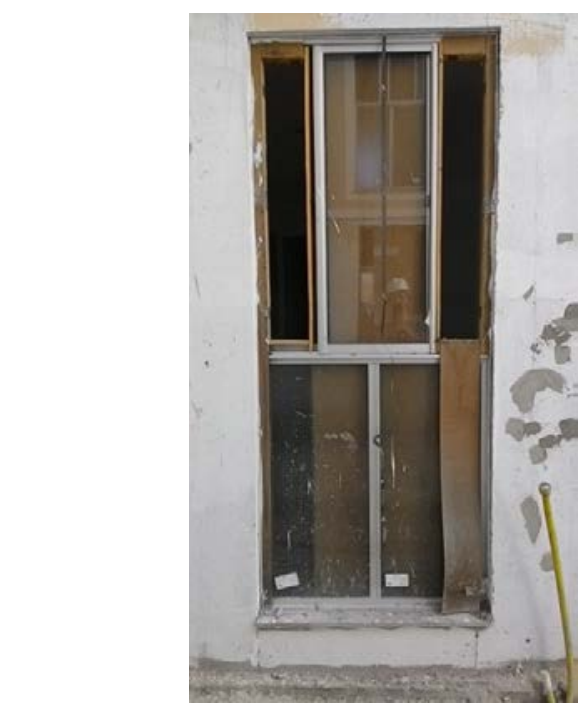

FONTE: Acervo da autora, 2017.

\section{Lajes pré-fabricadas}

Na obra do ALV_APTO, as lajes eram pré-fabricadas no próprio canteiro. Por se tratar de um empreendimento em alvenaria estrutural, as lajes precisavam ser executadas separadamente das paredes, eram dois subsistemas construtivos. A solução de pré-fabricar as lajes representava ganhos significativos de produtividade dentro do canteiro de obras. 0 "PES 44 - Laje pré-moldada içada” norteia a execução das lajes maciças de concreto. 
Existiam duas bases para moldar as lajes. O processo de execução se iniciava com a aplicação do desmoldante na base, para facilitar a desenforma (Imagem 53). 0 estagiário afirmou que antes eram utilizadas lonas ao invés do desmoldante, mas para reduzir custos, o processo foi mudado.

Em seguida eram colocadas a ferragem (sobre um espaçador de 2,5 cm) e as mangueiras de instalações elétricas e hidráulicas (Imagem 55). Feito isso, era realizada a concretagem das lajes. 0 caminhão de concreto usinado lançava o concreto direto na base, sem a necessidade de bombas (Imagem 56). Como era utilizado o concreto ARI (Alta Resistência Inicial), em menos de um dia as lajes eram desenformadas. Alguns trabalhadores auxiliam nesse processo, para espalhar e vibrar o concreto (Imagem 57).

Depois disso, as lajes eram empilhadas de dez em dez durante 7 dias, até o primeiro laudo do teste de resistência estar pronto. 0 concreto deveria atingir, ao final do processo, $25 \mathrm{MPa}$. Se no primeiro laudo ele já tiver atingido $66 \%$ dos $25 \mathrm{MPa}$, a laje já podia ser içada e instalada no edifício (Imagem 59). Caso não fossem atingidos os $66 \%$, era preciso aguardar 28 dias e refazer o teste. Caso ainda não atinja a resistência, pode-se realizar um último teste. Esse problema não ocorreu nessa obra.

Imagem 53 - Base de lajes com desmoldante no ALV_APTO.

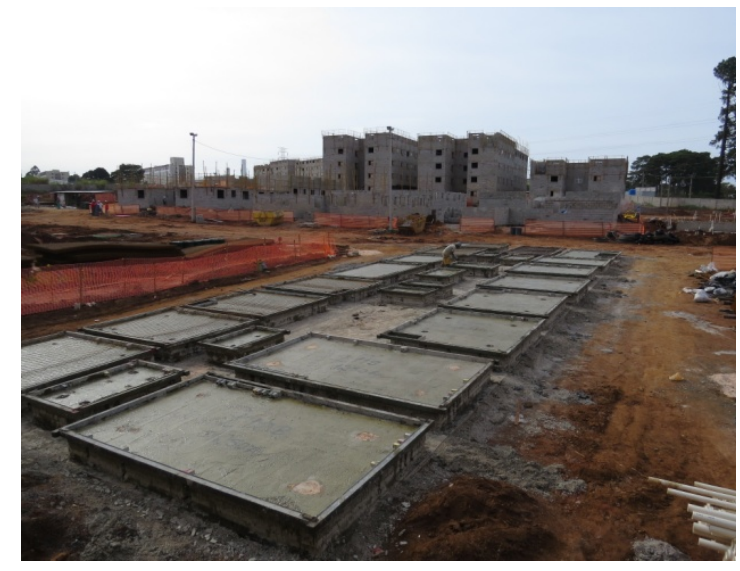

FONTE: Acervo da autora, 2013.
Imagem 54 - Preparação da armadura das lajes no ALV_APTO.

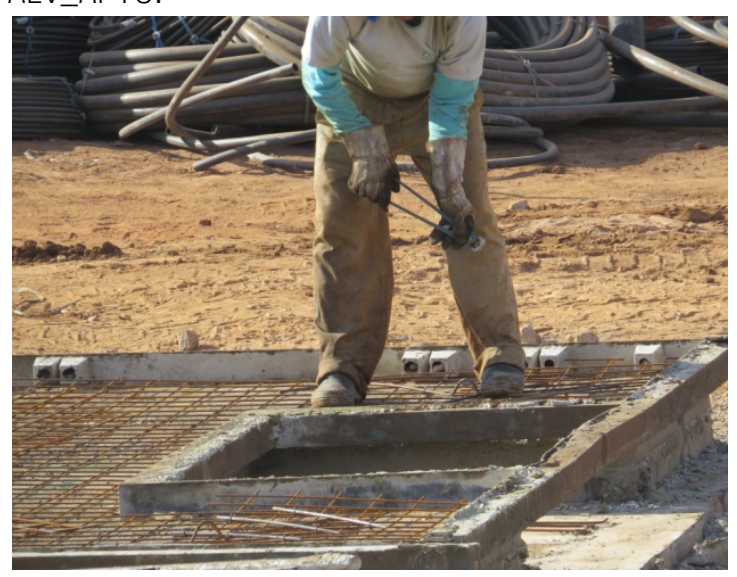

FONTE: Acervo da autora, 2013. 
Imagem 55 - Preparação da armadura e dos Imagem 56-Concretagem das lajes no ALV_APTO. conduítes das lajes e no ALV_APTO.

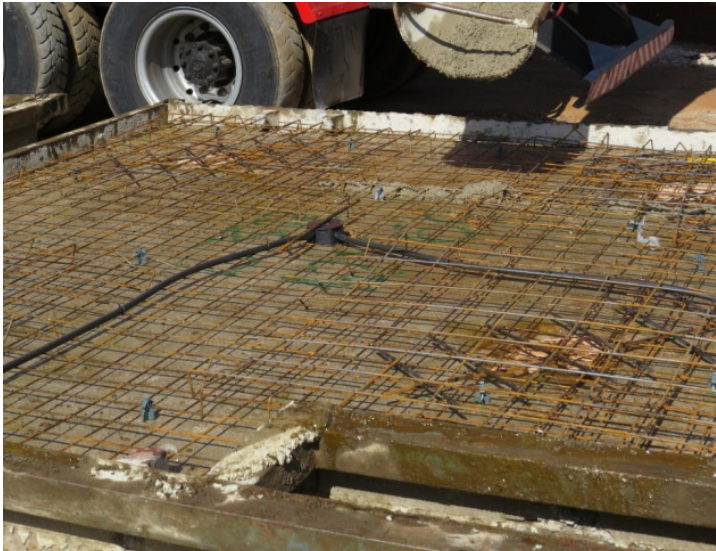

FONTE: Acervo da autora, 2013

Imagem 57 - Concretagem das lajes no ALV_APTO.

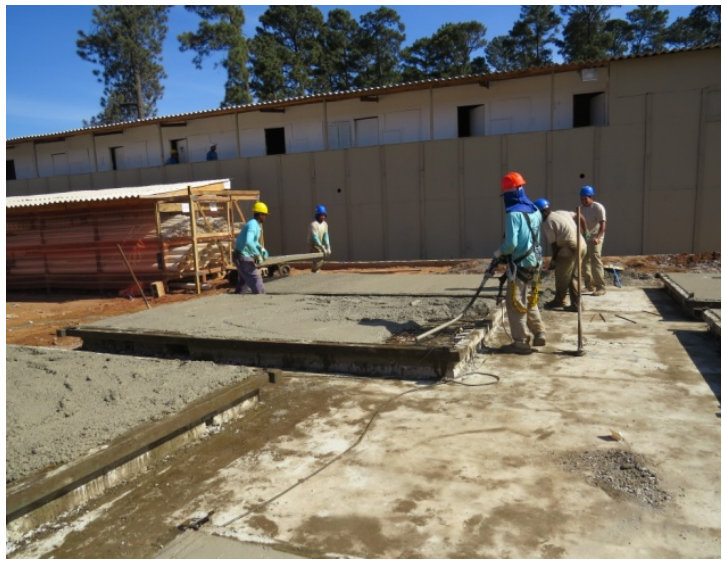

FONTE: Acervo da autora, 2013.

Imagem 59 - Içamento das lajes no ALV_APTO.

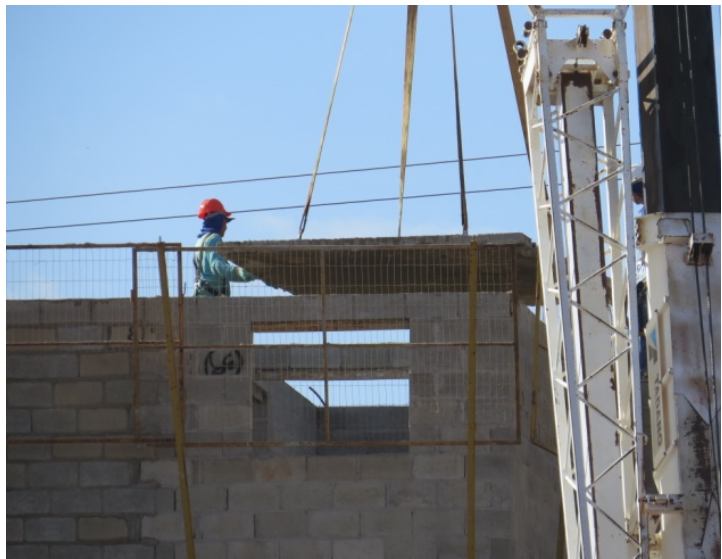

FONTE: Acervo da autora, 2013.

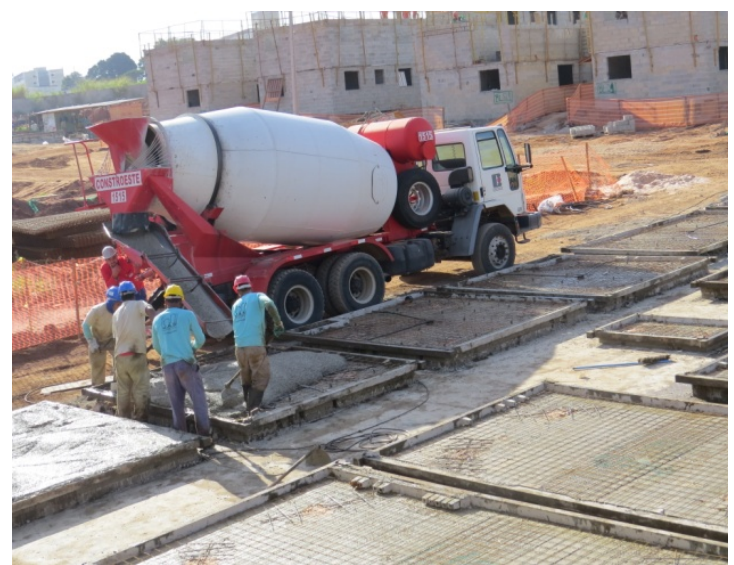

FONTE: Acervo da autora, 2013

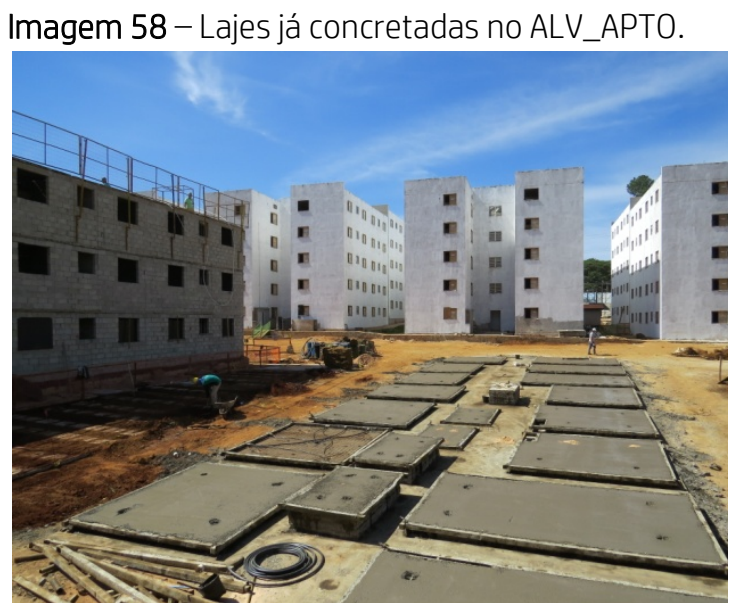

FONTE: Acervo da autora, 2014.

Imagem 60 - Lajes já instaladas no ALV_APTO.

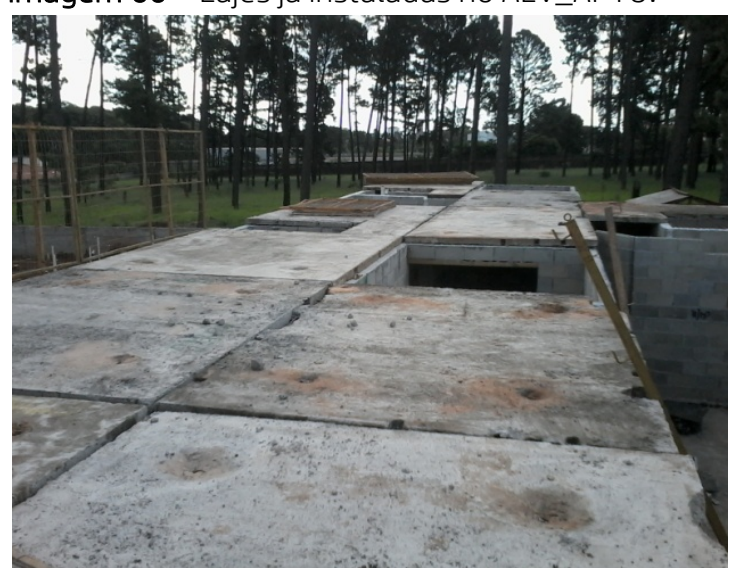

FONTE: Acervo da autora, 2013

De acordo com o estagiário que era responsável pela execução das lajes, a peça prémoldada se difere estruturalmente daquelas concretadas diretamente no edifício. As 
lajes concretadas no edifício são executadas com vigotas de concreto que distribuem as cargas apenas em uma direção, ou seja, a carga total acaba distribuída apenas em duas paredes. No caso da laje pré-moldada, não há vigotas, mas sim uma malha de ferro, o que faz com que a carga seja distribuída igualmente nas duas direções, ou seja, a carga vai ser distribuída sobre as quatro paredes. Apesar disso, ambas tem bom desempenho estrutural e a diferença do custo era pequena, apesar da prémoldada ser ligeiramente mais barata. Todavia, a laje pré-moldada acaba gerando uma grande economia de tempo, uma vez que a cura do concreto das lajes é atingida no canteiro e não no edifício. Ou seja, uma vez que as lajes estão prontas, já podem ser instaladas no edifício e a obra pode prosseguir. Quando a laje é concretada no edifício, a execução precisa ser paralisada até o concreto atingir a resistência ideal. A economia de tempo, portanto, é o que justifica de fato a escolha desse processo de execução e indiretamente representa redução de custos também.

As lajes não eram impermeabilizadas durante seu processo de produção. Era utilizado apenas um desmoldante nas formas, depois era executada a concretagem e por último aplicava-se o spoiler, um tipo de rodo utilizado apenas para nivelar a laje. A impermeabilização era feita apenas nas lajes dos banheiros e cozinhas depois delas já terem sido instaladas. Em algumas obras apenas as lajes dos banheiros são impermeabilizadas.

O estagiário - que era o responsável pela fabricação e colocação das lajes - disse que no processo de concretagem das lajes desperdiça-se muito concreto. Os operários colocam muito concreto na forma e depois acabam jogando o excesso no chão. De um caminhão de $8 \mathrm{~m}^{3}$ de concreto, na fabricação das lajes eram desperdiçados aproximadamente 300 litros. Para fins de comparação, a cada $90 \mathrm{~m}^{3}$ de concreto utilizados na execução do baldrame, eram desperdiçados os mesmos 300 litros. Esse fator denuncia uma falha considerável que ocorria na obra. A construtora optava por pré-fabricar as lajes no intuito de racionalizar a produção e consequentemente reduzir custos, mas não controlava satisfatoriamente a utilização do concreto. 


\subsection{Iniciativas de mecanização}

Como debatemos no capítulo 1, muitos estudos entendiam a mecanização da produção como uma etapa fundamental no processo de industrialização da construção. Dentro da interpretação clássica sobre os setores industriais, retirar das mãos do trabalhador a dominância do processo produtivo e transferi-la às máquinas configura o avanço da indústria.

Entretanto, as particularidades da ICCSE - e aqui ressaltamos a questão do canteiro de obras como o suporte da produção - dificultaram o processo de mecanização da produção. Baravelli (2014) discute e incorporação do processamento mecânico de argamassa de revestimento em algumas obras por ele analisadas. Tal iniciativa traria ganhos consideráveis de produtividade. Em compensação, com a mecanização as construtoras reduziriam o valor do serviço realizado pelas subempreiteiras, o que gerou um movimento de resistência da parte delas. 0 argumento de convencimento era que, apesar da redução do preço por $\mathrm{m}^{2}$, um operário aumentaria consideravelmente sua produção diária, o que, no final das contas significaria um salário maior em termos globais (BARAVELLI, 2014).

O fator salário por si só, não tornaria o trabalhador mais subalterno dentro do processo produtivo. Mas o fato desse operário não poder mais dominar sua produtividade, ou seja, controlar a qualidade e a velocidade do serviço executado, o tornaria mais subordinado. Baravelli (2014) identifica, nesse sentido, a resistência por parte dos trabalhadores em aceitar a máquina dentro do canteiro de obras.

\footnotetext{
Como nas demais transformações do capitalismo, as forças produtivas surgem antes que se implementem suas relações de produção. As inovações na fabricação e processamento mecânico da argamassa de revestimento se defrontam já prontas com a necessidade de alterar a mais conservadora forma de remuneração na construção habitacional: a da subempreitada (BARAVELLI, 2014, p. 43-44).
}

Mas o que seria efetivamente uma estratégia de mecanização dentro da construção civil? Considerando-se o setor da produção de edificações podemos afirmar que mecanizar a produção pode significar empregar máquinas e equipamentos de grande porte, por exemplo, mini-carregadeiras, caminhão-guindaste, escavadeiras, etc. Ou então, fazer uso de equipamentos pequenos que maximizem a eficiência de determinado serviço, como por exemplo, jateadoras de argamassa e betoneiras. 
A estratégia de mecanizar uma obra significa, de qualquer modo, substituir a mão de obra humana por algum tipo de máquina. 0 que pode variar é a intenção desta substituição. A mecanização pode ter como objetivo apenas agilizar determinado processo, ou então, pode buscar a máxima qualidade na execução de determinado serviço que talvez não fosse alcançada facilmente por um trabalhador.

Utilizar máquinas carregadeiras para realizar a limpeza do canteiro de obras ou executar este mesmo serviço com mão de obra humana não fará diferença no resultado final. Então, podemos admitir que a escolha por um ou por outro modo de execução deste serviço será baseada em questões externas à qualidade final do 'produto limpeza do canteiro'. Ou seja, a construtora terá que pesar o custo da mão de obra frente ao custo do aluguel das máquinas e estabelecer a relação custo-tempo para executar determinada quantidade deste serviço, ou por trabalhadores ou por máquinas.

A Empresa Nacional constantemente utilizava mini-carregadeiras para realizar o serviço de limpeza do canteiro. Na obra do PC_APTO_1, entretanto, houve um corte dessas máquinas e a limpeza passou a ser realizada pelos trabalhadores com auxílio de pequenos equipamentos, como carrinho de mão e pá. A única justificativa para esta mudança está no custo da execução do serviço. Em um período de crise econômica, com altas taxas de desemprego, é esperável que a oferta de mão de obra aumente e consequentemente seu custo diminua. Torna-se vantajoso para a empresa construtora dispensar as máquinas e contratar trabalhadores para substituí-las.

É claro que o volume de serviço também interfere diretamente na escolha da construtora entre a mecanização e o trabalho braçal. Em um canteiro de obras de grandes proporções, no qual o volume do serviço de limpeza, por exemplo, é expressivo, alugar uma máquina pode ser uma boa estratégia. Isto porque dificilmente a máquina ficará ociosa, abaixando, consequentemente seu custo.

Tomemos como exemplo o custo de um 'bobcat' (mini-carregadeira) utilizado na obra do PC_CASA_1. A Empresa Regional pagava R\$9.000,00 mensais pelo aluguel da máquina, já com o operador. Considerando-se 20 dias de trabalho em um mês, esta máquina custava à construtora cerca de $\mathrm{R} \$ 450,00$ por dia trabalhado. 0 u seja, cada dia ocioso da máquina tem um alto custo para a empresa. No caso do canteiro 
do PC_CASA_1, provavelmente este custo compensasse para a empresa, uma vez que a obra era muito grande, exigindo grande utilização da máquina. Em um canteiro pequeno, é possível que não haja serviço para uma máquina deste tipo o tempo todo, o que pode ser oneroso para a construtora.

Por outro lado, segundo o site 'piso salarial' 51 o salário médio mensal de um ajudante geral da Construção Civil é de $\mathrm{R} \$ 1.171,20$. Novamente considerando 20 dias de trabalho, um ajudante custa à empresa aproximadamente $\mathrm{R} \$ 58,00$ por dia. Portanto, grosso modo, a empresa pode contratar até sete funcionários que o valor total dos salários somados não atinge o custo mensal da 'bobcat'. A questão é analisar se esses sete trabalhadores são capazes de produzir ao menos o mesmo que uma máquina. Provavelmente, sim. Além dessa comparação bruta por quantidade de produção, devemos considerar também que um trabalhador pode exercer uma variedade grande de funções, ao contrário, por exemplo, da minicarregadeira. Se a máquina é bastante útil e eficiente na função de limpeza da obra, é absolutamente inútil para executar um reparo em um apartamento, por exemplo. 0 problema da ociosidade das máquinas não se aplica ao trabalhador, que pode facilmente ser remanejado entre diversas tarefas.

Nas obras analisadas, uma iniciativa muito clara de mecanização se via através da utilização do concreto usinado. No sistema e paredes de concreto, a utilização de caminhões-bomba é imprescindível. De acordo com Baravelli (2014), o caminhão betoneira - podemos expandir essa observação também para os caminhões-bomba - representa uma extensão da mecanização da indústria de insumos. Esse equipamento permite o transporte dos insumos já dosados e preparados em outra indústria. Efetivamente, essa iniciativa representa maior controle do ponto de vista da qualidade do produto e também a eliminação da estocagem dos respectivos insumos dentro do canteiro de obras.

Em alguns canteiros pesquisados foi possível observar também a utilização de grandes máquinas que serviam ao transporte interno de materiais, como a skytrack 
e o caminhão munck. A skytrack era usada para o transporte vertical de materiais peletizados, e foi utilizada na obra do ALV_APTO. Nessa obra, executada com alvenaria estrutural, essa máquina tinha função principal de elevar paletes de blocos de concreto até os pavimentos superiores das edificações. 0 munck foi utilizado em algumas das obras observadas e tinha uma função mais geral. Servia tanto para transporte horizontal de qualquer tipo de material e também era utilizado como um pequeno guincho. No canteiro do PC_APT0_1, por exemplo, o munck era utilizado para içar as telas de armaduras até os respectivos pavimentos.

Se comparado ao sistema executado em alvenaria estrutural, o sistema de paredes de concreto demanda menor necessidade de transporte de materiais e insumos. As peças das fôrmas já são ideais para carregamento manual, mesmo de um pavimento a outro. Já são previstos, inclusive, andaimes que ficam fixados nos pavimentos já concretados e permitem que os operários circulem facilmente durante as etapas de montagem, que envolvem o transporte das peças das fôrmas. Por outro lado, a utilização do concreto usinado aumenta consideravelmente e os caminhões-bomba são fundamentais nesse processo.

Ao contrário do que Baravelli (2014) observou em sua pesquisa de campo, não existia nas obras aqui analisadas, outras iniciativas de mecanização, como por exemplo, a argamassa industrializada. De modo geral, os serviços ficavam a cargo do trabalhador e de suas ferramentas usuais.

\footnotetext{
De fato, a mecanização do processo de trabalho unifica "fazer" e "saber fazer" como funções da gerência do capital e, neste sentido, a análise da argamassa de revestimento como tipo ideal traz esta pesquisa para o ponto principal: a tecnologia de gestão e organização do trabalho. Ela, mais que a mecanização, é o ponto sem retorno da industrialização dos canteiros de obras do programa MCMV (BARAVELLI, 2014, p. 47).
}

Baravelli (2014) entende que a mecanização não é uma condição essencial para a industrialização da construção. Em seu ponto de vista, apenas o processo de racionalização do processo de trabalho foi suficiente para modificar a estrutura produtiva, eliminando a organização manufatureira. 0 capital, através de estratégias de gestão e controle, domina o processo de trabalho e, por si só, essa configuração constitui a industrialização da produção. Baravelli (2014) afirma que dentro dos canteiros do MCMV a industrialização já está posta, mesmo que a mecanização ainda seja incompleta. 


\section{CAPÍTULO 3}

Regulamentação e controle do trabalho

A questão da regulamentação e do controle do trabalho na ICCSE há tempos está em pauta. O setor no Brasil, como já destacamos, é marcado como grande absorvedor de mão de obra. Esse fator, por si só, já levanta o debate sobre como esses trabalhadores são geridos por aqueles que detêm o capital e também como o Estado interfere nessa relação. A questão da regulamentação e do controle do trabalho na ICCSE há tempos está em pauta. O setor no Brasil, como já destacamos, é marcado como absorvedor de mão de obra.

Nesse sentido, a dinâmica do trabalho dentro do canteiro de obras perpassa inevitavelmente seu formato de regulamentação e controle. Cabe primeiramente, entretanto, compreender quem é o trabalhador presente dentro da produção recente da habitação. Shimbo (2012) recupera alguns autores ${ }^{52}$ que se inseriram no debate acerca do trabalhador da construção civil na década de 1980 no Brasil e demonstra que historicamente a figura do trabalhador da construção foi carregada de estigmas pejorativos, do indivíduo ignorante, miserável, desvalorizado 
socialmente, conhecido no imaginário popular como o 'peão'. A própria experiência nos canteiros de obras poderia ser responsável por enraizar, nos próprios trabalhadores, essa noção de submissão e inferioridade.

\begin{abstract}
Muito propagada, tal visão pode aparentemente ser confirmada por várias observações, assim como pela própria opinião negativa dos operários sobre si mesmo. Ela é, porém, enganosa porque subentende a existência de um perfil típico, único, homogêneo e imutável do trabalhador, o que não se confirma nos canteiros de obras; ademais, ela esconde que o emprego na construção oferece, a uma proporção notável de migrantes, a possibilidade de se fixar de vez na cidade (MORICE,1992, p.35).
\end{abstract}

A partir da década de 1990, entretanto, alguns estudos ${ }^{53}$ passaram a apontar mudanças no perfil do trabalhador da construção. Um primeiro fator considerável foi a diminuição de migrantes recentes, o que demonstra que os trabalhadores começaram a se fixar durante mais tempo em um mesmo local. Houve também uma redução na porcentagem de trabalhadores analfabetos e naturalmente, um aumento nos índices de escolaridade. Apesar disso de modo geral as condições de trabalho, no que dizia respeito à regulamentação, ainda eram precárias (Shimbo, 2012).

Com base nesses estudos e também em sua observação empírica, Shimbo (2012) reforça que não é possível enquadrar o trabalhador da construção na figura do "peão". A autora reforça que nos canteiros da construção recentes, existe uma variedade considerável no perfil dos trabalhadores, que podem ser migrantes recentes, migrantes já consolidados ou mesmo aqueles que já marcaram passagem por diversos lugares.

Nesse sentido, procuraremos neste capítulo, abordar as observações de campo acerca do trabalho nos canteiros de obras da produção em larga escala da habitação. Interessa-nos, sobretudo, apresentar os modelos de organização e regulamentação do trabalho adotados pelas empresas construtoras pesquisadas.

Uma questão pertinente nesse debate é justamente a predominância da subempreitada nesse tipo de produção da ICCSE. Além disso abordaremos as estratégias informatizadas de controle. Discutiremos também a forma de controle 
do trabalho dentro do canteiro, que dialoga diretamente com a forma de contratação dos trabalhadores. Finalmente, traremos o debate sobre o processo de trabalho nos canteiros de obras analisados e em qual medida se insere na discussão sobre a industrialização da ICCSE.

\subsection{Os trabalhadores da Empresa Nacional}

No final de 2016, a Empresa Nacional contava com aproximadamente 18.000 trabalhadores nas obras, entre mão de obra própria e terceirizada. A estrutura da produção é formada por estagiários, auxiliares, coordenadores gestores e por fim, os diretores. A pirâmide a seguir, disponibilizada no site da empresa, detalha as informações sobre os 'colaboradores' - como são chamados os profissionais que trabalham com a construtora.

Gráfico 6 - Pirâmide de produção.

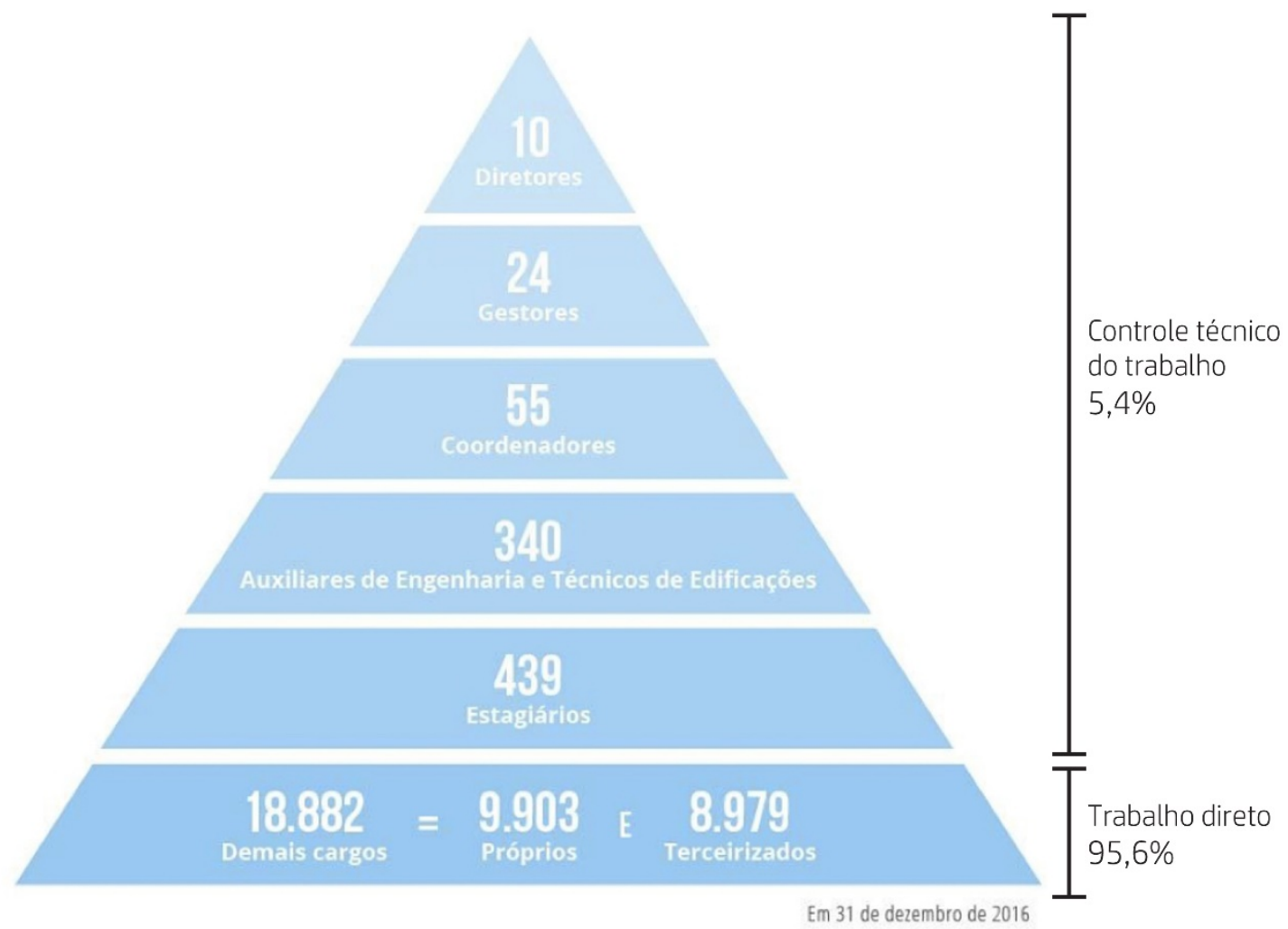

FONTE: Site da construtora, dados de 31 de dezembro de 2016. Acesso em: Nov. 2016. 
Evidentemente, a estrutura acima é simplificada ${ }^{54}$, mas os números permitem algumas ponderações. Somando-se todos os cargos, a empresa tinha 19.750 trabalhadores no final de 2016. Desse total, a pirâmide mostra que 18.882, ou seja 95,6\%, são aqueles responsáveis pelo que chamamos de trabalho direto, de acordo com a conceituação de Jaramillo (1987). Os outros 4,4\% compõem o controle técnico do trabalho, que totalizava 868 trabalhadores. Isso demonstra uma estrutura bastante hierárquica e centralizada. 0 Gráfico a seguir apresenta a porcentagem dos trabalhadores que configuram o controle técnico do trabalho.

Gráfico 7 - Controle técnico do trabalho na Empresa Nacional (\%).

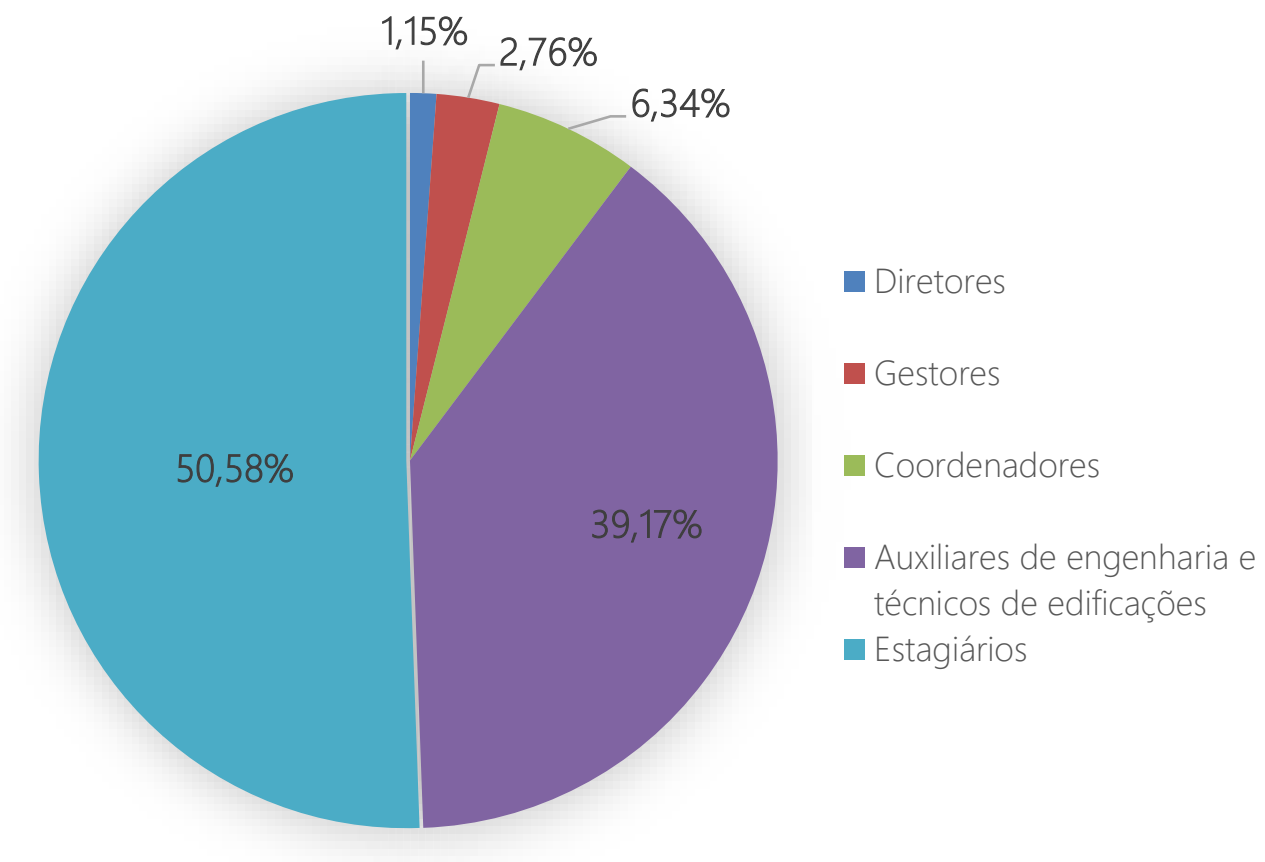

FONTE: Elaboração própria a partir de dados do Gráfico 6, jun/2018.

Em relação aos trabalhadores das obras, entre 2007 e 2008, a construtora dobrou o número de empregados, justamente no momento em que abriu seu capital. A partir daí, passou a empregar cada vez mais, chegando a um impressionante número de

${ }^{54}$ Shimbo (2012) descreve mais detalhadamente o funcionamento da Empresa Nacional na época de sua pesquisa. A organização da Nacional é, na verdade, bastante complexa, formada por Conselhos, Diretorias, Comitês e Departamentos. 
29.600 empregados em suas obras no ano de 2012. De 2013 em diante, esse número foi decrescendo, sendo que de 2015 para 2016, houve queda de aproximadamente 5.000 postos de trabalho. Houve mudanças também no padrão de contratação desses empregados. De 2013 para 2014, a porcentagem de trabalhadores diretamente contratados aumentou consideravelmente em relação aos terceirizados. Em 2015 e 2016, entretanto, a terceirização voltou a crescer dentro da Nacional. Todas essas informações podem ser observadas no gráfico abaixo ${ }^{55}$.

Gráfico 8 - Evolução no número de empregados nas obras da Empresa Nacional.

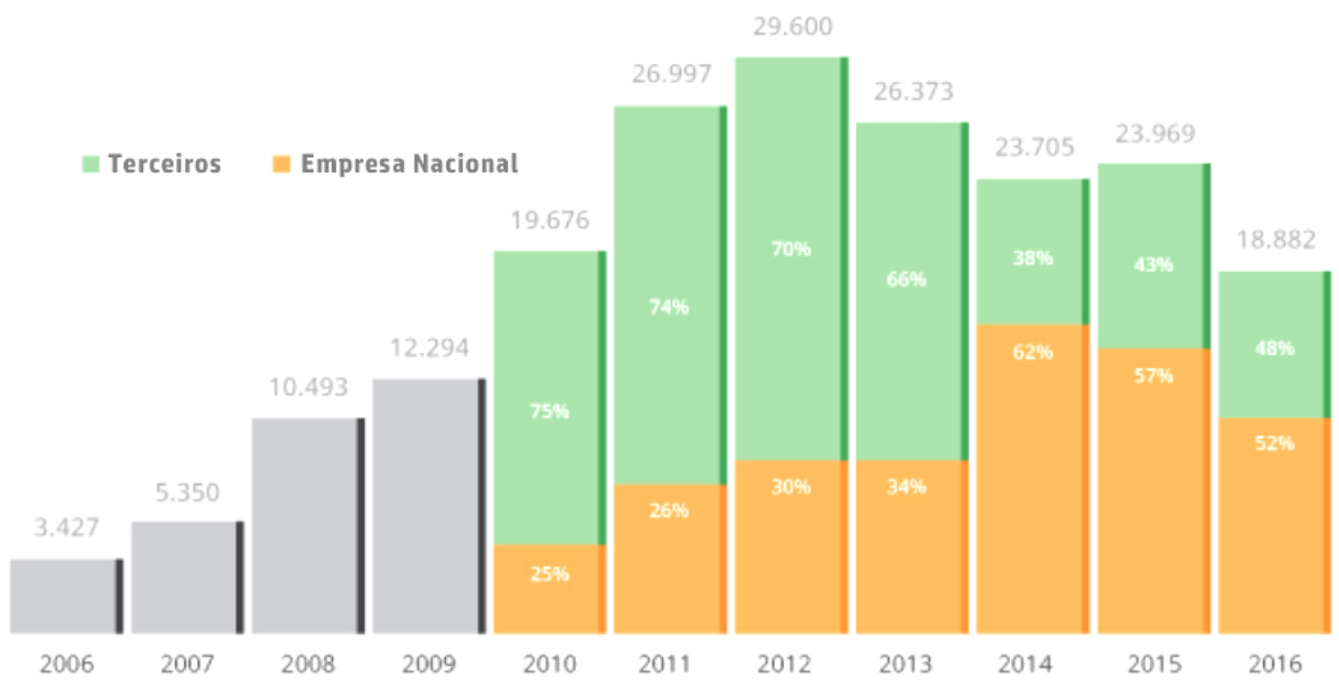

FONTE: Site da construtora. Acesso em: Nov. 2017.

Nos últimos anos, a crise econômica se agravou no Brasil, o que provavelmente colaborou para a redução no número absoluto de trabalhadores da empresa. Além disso, como debatemos no capítulo anterior, a Nacional está substituindo gradualmente a alvenaria estrutural pelas paredes de concreto em suas obras, o que pode ser um fator relevante para a diminuição no número de trabalhadores. Já a questão da mão de obra própria e da terceirização possivelmente está relacionada a um acordo firmado pela Nacional com o Ministério Público do Trabalho (MPT),

55 Os dados das colunas em cinza - ou seja do intervalo entre 2006 e 2009 - referem-se aos números totais de trabalhadores empregados, a Nacional não discriminou a porcentagem de terceirizados e contratação própria. 
realizado exatamente no período em que a empresa passou a contratar diretamente grande parte dos trabalhadores. Mais adiante retornaremos a essa questão. A terceirização ou a subempreitada, entretanto, geralmente representa vantagem financeira para as construtoras, o que explica sua retomada nos anos subsequentes. Geralmente, as empresas que executam os serviços terceirizados trabalham em várias obras distintas com a construtora. Elas são responsáveis pelo serviço, mas a construtora é que cuida da parte de orçamento, material, etc. Os funcionários do corpo técnico eram contratados diretamente pela Empresa Nacional e tinham formação de nível superior.

Na obra do ALV_APTO, um dos engenheiros era formado em engenharia civil e trabalhava há cinco anos na Nacional, sendo dois anos como estagiário e três como engenheiro. Começou a trabalhar na empresa em uma obra em Araraquara e foi transferido para São Carlos para coordenar a obra do ALV_APTO. A auxiliar de engenharia era estudante do quarto ano da graduação do curso de engenharia civil da UNIARA, de Araraquara e trabalhava na construtora há três anos. Começou como estagiária e como atingiu o tempo máximo nessa função, foi promovida a auxiliar de engenharia. Perguntei a ela qual era a diferença de função dos dois cargos e ela respondeu: "de verdade mesmo, nenhuma". Ela disse que passou a acompanhar mais o trabalho no escritório - como a parte de compra, levantamento, custo e produção - e ficar menos tempo no canteiro de obras. Para ela, o trabalho no escritório era mais monótono, "ficar no canteiro é mais dinâmico, mas às vezes cansa bastante, principalmente quando tem muito sol" 56. Já trabalhou em quatro obras da Nacional, inclusive em um canteiro vizinho, no qual exercia a mesma função, mas mudou de obra devido à logística de funcionários. Porém, afirmou que esse processo não é usual e normalmente os funcionários permanecem na mesma obra do início ao fim. Um dos estagiários estava no quinto ano do curso de engenharia civil e fazia estágio na construtora há dez meses. Ele estava supervisionando o processo de fabricação e colocação das lajes. 0 almoxarife trabalhava há um ano e meio na

\footnotetext{
${ }^{56}$ Depoimento da auxiliar de engenharia.
} 
empresa. Iniciou os cursos de design gráfico e biologia, mas só concluiu o curso de Gestão em Negócios.

Na obra do PC_APTO_2, 74 trabalhadores subempreitados eram responsáveis pela execução do sistema construtivo. Entre eles, 30 funcionários faziam montagem e desmontagem das fôrmas e a concretagem; 5 operários faziam o serviço de armação e mais 2 funcionários eram responsáveis por outros serviços gerais. Também existia no canteiro uma equipe de quatro funcionários também subempreitados que faziam a montagem dos 'kits' elétricos. Além disso, existia uma equipe para a colocação de portas e janelas, composta por 15 funcionários, estes, diretamente contratados pela construtora.

Para a execução das paredes de concreto, no PC_APTO_1, as empreiteiras contratadas inicialmente não conseguiram chegar a um resultado satisfatório e a solução foi trazer uma equipe do estado do Maranhão. Os novos trabalhadores também empreitados - já haviam executado as paredes em outras obras da construtora no Nordeste e conseguiram facilmente atingir a produtividade esperada. Já no PC_APTO_2, os trabalhadores foram trazidos de cidades próximas: Piracicaba e Campinas. Como foi a primeira obra executada com paredes de concreto em São Carlos, a construtora não conseguiu encontrar empreiteiros locais que executassem o serviço.

Em uma das visitas ao empreendimento PC_APT0_1, questionei sobre o emprego da mão de obra, considerando-se o sistema construtivo de paredes de concreto em relação à alvenaria estrutural. 0 engenheiro afirmou que se fosse executada em alvenaria estrutural seriam necessários em torno de 40 ou 50 bloqueiros. Nessa obra tinham apenas cinco ou seis - para a construção dos apartamentos PNE e das áreas de apoio. Com as paredes de concreto, havia cerca de 30 trabalhadores responsáveis pela execução do sistema construtivo. Diretamente, isso representa uma redução de pelo menos 10 trabalhadores.

Em outra visita ao mesmo empreendimento, questionei o encarregado sobre o "novo" sistema construtivo implementado pela construtora. Ele disse que achou mais fácil, disse que parecia mais rápido. Em seguida, porém desabafou, dizendo que, para ele que tinha emprego garantido estava ótimo, entretanto, para quem estava precisando trabalhar não foi uma boa coisa. Isso porque, segundo ele, muitos 
serviços foram cortados com esse sistema construtivo, como por exemplo, serviço de chapisco, reboco, contrapiso, etc. Além disso, o número de trabalhadores nesse novo sistema é, segundo o encarregado, muito menor do que no trabalho com alvenaria estrutural. Ele afirmou ainda que estava triste pelos colegas que estavam desempregados no momento.

\subsection{Os trabalhadores da Empresa Regional}

A Empresa Regional, diferentemente da Nacional, utilizava a estratégia de contratar diretamente os trabalhadores responsáveis pelas paredes de concreto. No caso do PC_CASA_2, 16 funcionários que executavam a estrutura eram diretamente contratados pela empresa. Segundo o engenheiro, esses são trabalhadores que se destacam e que a construtora procura contratar. Como uma forma de incentivo, a construtora divide o salário entre uma parte fixa e mais uma bonificação por unidade construída. Além disso, cada equipe de trabalhadores tem um 'líder', que é justamente aquele trabalhador que mais se destaca e que tem, evidentemente, uma bonificação maior. Este sistema de contratação e bonificação, de acordo com o engenheiro, é um incentivo para que o trabalhador permaneça na empresa. Para a construtora, este fator é bastante positivo, uma vez que eles treinam alguns poucos funcionários e os mantém sempre na mesma função. Desse modo, evitam problemas como a falta de mão de obra ou inexperiência. 0 engenheiro disse ainda que para treinar estas equipes, a Regional trouxe um mestre de obras de uma grande empresa construtora que já trabalhava com o sistema de paredes de concretos moldadas no canteiro e que ele foi o responsável por ensinar a utilização das fôrmas e todo o processo produtivo.

No PC_CASA_1, somente o serviço de produção das casas foi realizado por uma equipe própria. Para todos os outros serviços - como fundação, cobertura, piso, pintura, elétrica, hidráulica - foram contratadas 23 empreiteiras. Segundo o engenheiro, financeiramente o regime da subempreitada é mais vantajoso, apesar da construtora ainda ter responsabilidade legal pelos trabalhadores. Existiam 300 funcionários no canteiro, durante as etapas finais de execução da obra. Desses 300, 126 estavam alojados no próprio canteiro de obras, os outros moravam em outros alojamentos na cidade. Em etapas anteriores, o número de trabalhadores era um 
pouco menor, cerca de 200. Existiam ainda dois engenheiros e dois estagiários, estes diretamente contratados.

\subsection{A predominância da subempreitada}

A subcontratação nas atividades da construção é colocada por Farah (1992) como uma tendência das empresas da ICCSE a partir dos anos 1980. A autora identificou a intensificação dessa prática como uma estratégia de adaptação à crise que ocorria na época. 0 modelo se desvencilhava de responsabilidades trabalhistas, e não previa direitos ao trabalhador, como registro em carteira, 13ํㅗa salário, férias remuneradas, etc. Além disso, agravava a situação dos trabalhadores nos canteiros, no que se referia à segurança, higiene, alimentação, etc. Justamente, os ganhos das empresas construtoras se concentravam na diminuição do quadro de funcionários e, consequentemente, na redução dos encargos trabalhistas. Farah (1992) afirma que a intensificação da subcontratação resultou na precarização das condições de trabalho nos anos 1980 e também no achatamento do poder de compra dos trabalhadores.

\footnotetext{
0 recurso à subcontratação constitui, por um lado, uma estratégia de transferência da variabilidade inscrita no processo produtivo para as subempreiteiras, estratégia reforçada com a potencialização dos riscos envolvidos na atividade construtiva nos anos 80. Por outro lado, a subcontratação crescente assinala uma reiteração de mecanismos tradicionais de redução de custos, através da compressão de gastos com a mão de obra, sem que tal redução implique alteraç̃̃es na base técnica. Com relação à organização do trabalho, por sua vez, intensifica-se a fragmentação e a segmentação do processo produtivo (FARAH, 1992, p. 59).
}

De acordo com Villela (2007), a subcontratação é uma categoria da 'terceirização'. Por terceirização é possível entender uma prática de flexibilização da força de trabalho que consiste na

[...] contratação de empresas terceiras para realizar determinadas atividades no interior da empresa cliente ou pela transferência de parte da produção para terceiros (VILLELA, 2007, p.198).

Trata-se de uma estratégia antiga, mas que foi apropriada pelo modelo toyotista nos anos 1990. A prática da terceirização teria assumido múltiplas facetas, como: trabalho domiciliar; empresas fornecedoras de componentes e peças; 
subcontratação para serviços de apoio; subcontratação de empresas e/ou trabalhadores autônomos; quarteirização ${ }^{57}$ (VILLELA, 2007).

Em relação à ICCSE, Shimbo (2012) destaca a que, dentro dos canteiros de obras, existe uma distinção entre a subempreitada e a terceirização. Basicamente, os serviços que passavam por um processo de cotação, ou seja, que dependiam do crivo de equipes externas ao canteiro eram entendidos como terceirizados. Os que eram negociados diretamente nas obras consistiam na subempreitada.

Em todos os empreendimentos analisados, a maior parte dos serviços era executado através da subempreitada. De modo geral, as construtoras optavam por contratar diretamente a equipe técnico-administrativa, formada por engenheiros, auxiliares, estagiários, mestres de obra, almoxarife e ajudantes. Em duas situações, as construtoras optaram por contratar diretamente os trabalhadores responsáveis pela estrutura - alvenaria estrutural e paredes de concreto - como analisaremos a seguir.

Baravelli (2014), afirmou categoricamente que a prática da subempreitada dos serviços de execução nos empreendimentos habitacionais do PMCMV era universal. Em sua pesquisa em 22 obras, o autor identificou equipes especializadas para todos os serviços das obras. A universalização da subempreitada era tão consolidada que do ponto de vista das construtoras, "enquanto não houver pelo menos a précontratação das principais etapas da obra, o empreendimento não é sequer levado para aprovação junto à CEF" (BARAVELLI, 2014, p.139).

É possível inferir, portanto, que a situação identificada por Baravelli (2014) na produção do MCMV na região metropolitana de São Paulo se aplique também aos empreendimentos do MCMV do interior do estado, que foram o objeto dessa pesquisa. Apesar do PMCMV não ser o recorte desse trabalho, todos os empreendimentos analisados se enquadravam no Programa. 
O regime da subempreitada analisado por Baravelli (2014) não tem exatamente o mesmo funcionamento daquele identificado por Farah (1992) na década de 1980. Existe maior regulamentação trabalhista e as empresas construtoras têm responsabilidade legal sobre os trabalhadores subcontratados. Mesmo assim, a subempreitada representa vantagens consideráveis para as construtoras. Uma dessas vantagens se dá sobre a produtividade, não do ponto de vista da redução dos prazos de execução, mas da diminuição do preço da força de trabalho. Além disso, os valores contratados são pré-fixados, o que facilita o controle por parte das construtoras. Os custos de produção são transferidos para os contratos de prestação de serviços, o que gera economia para a construtora. Máquinas e equipamentos muitas vezes ficam também a cargo das subempreiteiras que executam os serviços. A ociosidade dos trabalhadores também é reduzida na subempreitada, uma vez que o uso da força de trabalho é realizado de acordo com a demanda de serviço (BARAVELLI, 2014, p. 145).

Dentro da produção do MCMV, as construtoras mantêm algumas atividades sob domínio próprio. São atividades que constroem também o retrato comercial da empresa e, portanto, não costumam ser terceirizadas, como: "planejamento e programação; controle do processo produtivo; qualidade de serviços" (BARAVELLI, 2014, p.146).

Baravelli (2014) também identifica um resultado negativo da subempreitada que é justamente o distanciamento entre as equipes de trabalho e a equipe técnica da obra. Ou seja, os trabalhadores subempreitados precisam se adaptar às exigências da construtora, e fica a cargo da gerência do canteiro controlar esse processo. Além disso, algumas ações motivacionais como bônus por produtividade não se estendem aos trabalhadores subempreitados.

Coloca-se nesse sentido, o desafio às construtoras que contratam as subempreiteiras: integrar diversas atividades complexas da construção ${ }^{58}$. Nossas

${ }^{58}$ Baravelli (2014) apresenta a concepção de Sabbatini (1998) da empresa construtora como 'integradora de sistemas complexos', na qual a integração dos sistemas não se trata apenas de gerenciar a subcontratação das atividades, mas sim de avançar no planejamento sistêmico e nos projetos. A estratégia é muito mais gerencial do que executiva, trata-se da empresa que é "mais cérebro do que braço". 
análises de campo demonstraram, assim como as de Baravelli (2014), que a prática da subempreitada é recorrente e universal dentro da produção habitacional de larga escala.

Entre os serviços subempreitados estavam a própria execução da estrutura, a montagem das instalações elétricas e hidráulicas, a execução da cobertura, a pintura, a colocação de portas e janelas, o assentamento de pisos e azulejos, os acabamentos, e até mesmo a limpeza. Houve algumas poucas situações nas quais as empresas saíram desse padrão, como veremos a seguir.

Basicamente, as construtoras buscavam subempreiteiras da região para executar os respectivos serviços. Era comum que uma subempreiteira já tivesse executado várias obras de uma mesma construtora. A Empresa Nacional, por exemplo, tinha a estratégia manter as empreiteiras que apresentassem resultados satisfatórios em outras obras da região. Desse modo, a construtora tinha a vantagem de não precisar adaptar e instruir a mão de obra a cada novo empreendimento, mas também não precisava contratar diretamente e arcar com os encargos de cada trabalhador.

A partir de informações coletadas nas visitas de campo, foi possível elaborar um quadro com as principais empresas subempreitadas da obra do ALV_APTO, da Empresa Nacional. Segue a tabela com os serviços feitos na obra e seus respectivos responsáveis: 
Quadro 4 - Empresas prestadoras de serviços de construção do ALV_APTO.

\begin{tabular}{|c|c|c|c|}
\hline \multicolumn{2}{|c|}{ TIPO DE SERVIÇO } & \multirow{2}{*}{\begin{tabular}{|l} 
LOCALIZAÇÃO DA SEDE \\
---
\end{tabular}} & \multirow{2}{*}{$\begin{array}{l}\text { ÁREA DE ATUAÇÃO } \\
---\end{array}$} \\
\hline Droliminarer & Levantamento planialtimétrico & & \\
\hline म & Terraplanagem e contenção & SÃO CARLOS/SP & REGIONAL LOCAL \\
\hline \multirow{6}{*}{ Execução } & Fundação & SÃO CARLOS/SP & REGIONAL LOCAL \\
\hline & Impermeabilização & BELO HORIZONTE/MG & NACIONAL \\
\hline & Estrutura principal & BELO HORIZONTE/MG & NACIONAL \\
\hline & Vedações & BELO HORIZONTE/MG & NACIONAL \\
\hline & Lajes & --- & --- \\
\hline & Cobertura - Estrutura metálica & SÃO CARLOS/SP & REGIONAL LOCAL \\
\hline \multirow{5}{*}{ Instalação } & Hidráulica & --- & --- \\
\hline & Elétrica & ARARAQUARA/SP & REGIONAL LOCAL \\
\hline & Esquadrias & BELO HORIZONTE/MG & NACIONAL \\
\hline & Proteção incêndio & --- & --- \\
\hline & Proteção descargas atmosféricas & --- & --- \\
\hline \multirow{4}{*}{ Acabamento } & Gesso & --- & --- \\
\hline & Revestimento & BELO HORIZONTE/MG & NACIONAL \\
\hline & Pintura & SÃO CARLOS/SP & REGIONAL LOCAL \\
\hline & Pintura & --- & --- \\
\hline
\end{tabular}

FONTE: Elaboração própria a partir de informações conseguidas nas visitas de campo, 2014.

A partir deste levantamento é possível perceber à exceção dos serviços executados pela equipe própria da Nacional, os outros serviços eram realizados por empresas atuantes na região de São Carlos, até onde pôde ser aferido.

O mesmo acontecia nos empreendimentos da Empresa Regional. A tabela a seguir mostra os serviços subempreitados e as respectivas empresas responsáveis do empreendimento PC_CASA_1, da Empresa Regional. 
Quadro 5 - Empresas e serviços subempreitados - PC_CASA_1.

\begin{tabular}{|c|c|}
\hline TIPO DE SERVIÇO (S) & LOCALIZAÇÃO \\
\hline Instalações hidráulicas, sanitárias e de gás & São Carlos \\
\hline $\begin{array}{l}\text { Acerto de terreno } \\
\text { Estacas } \\
\text { Garagem } \\
\text { Linha da vida } \\
\text { Muros } \\
\text { Telhamento } \\
\text { Trator/bobcat }\end{array}$ & --- \\
\hline--- & Mococa \\
\hline $\begin{array}{l}\text { Painel de ciclo } \\
\text { Pintura } \\
\text { Reboco do frizo } \\
\text { Requadro } \\
\text { Sikatop }\end{array}$ & --- \\
\hline $\begin{array}{l}\text { Drenagem } \\
\text { Ponto de esgoto }\end{array}$ & Rio Claro \\
\hline--- & Ibaté \\
\hline--- & São Carlos \\
\hline Colocação de portas e janelas & Minas Gerais \\
\hline Impermeabilização em obras de engenharia civil & Ibaté \\
\hline Instalação de aquecedor solar & São Carlos \\
\hline $\begin{array}{l}\text { Drenagem } \\
\text { Ponto de esgoto } \\
\text { Totem }\end{array}$ & São Carlos \\
\hline--- & São Carlos \\
\hline \multicolumn{2}{|l|}{ Requadro } \\
\hline--- & Jacareí \\
\hline $\begin{array}{l}\text { Piso/azulejo } \\
\text { Sikatop }\end{array}$ & --- \\
\hline $\begin{array}{l}\text { Drenagem } \\
\text { Totem }\end{array}$ & --- \\
\hline Teste de resistência do concreto (laboratório) & Araraquara \\
\hline
\end{tabular}

FONTE: Elaboração própria a partir de dados coletados na pesquisa de campo.

Não foi possível aferir a cidade de origem de todas as empresas, entretanto é notável que a grande maioria é da própria região de São Carlos.

De qualquer maneira, por esses levantamentos é possível afirmar que existe grande parcelização dos serviços nas obras habitacionais, cada qual executado pela respectiva subempreiteira. Entretanto, quando se contrata determinado serviço por subempreitada, corre-se o risco do subempreiteiro não manter um bom ritmo de produção ou até mesmo não manter um índice satisfatório de qualidade. Para evitar este tipo de problema, era comum que mais de uma empreiteira executasse um mesmo serviço dentro da obra. Estimulava-se assim a concorrência entre elas, uma 
vez que a construtora não ficava dependente de apenas uma empresa para cada atividade.

Em relação aos serviços mais comuns, geralmente não aconteciam grandes problemas com as subempreiteiras, no que diz respeito à execução. No caso das paredes de concreto, entretanto, as construtoras tiveram algumas dificuldades com a mão de obra. Em relação à execução de armaduras e instalações elétricas não havia grande novidade. Eram atividades já presentes em sistemas convencionais e na alvenaria estrutural. Já a montagem das fôrmas pode ser considerada uma atividade 'nova' dentro dos canteiros de obras do Brasil e as construtoras precisaram lidar com a adaptação da mão de obra disponível para executar esse serviço.

A estratégia da Empresa Nacional foi manter a execução das paredes de concreto com equipes subempreitadas. A construtora contratava subempreiteiros que estavam dispostos a se capacitar para o serviço e depois procurava manter essas equipes em outras obras. Já a Empresa Regional optava por contratar diretamente os trabalhadores responsáveis pelas paredes de concreto e assim criar um vínculo mais sólido com esses funcionários.

\subsection{A mudança na forma de contratação da Empresa Nacional}

Durante a execução do empreendimento ALV_APTO, ocorreu uma mudança na contratação de parte dos trabalhadores. Na primeira etapa das visitas poucos funcionários eram contratados diretamente pela Nacional: o engenheiro, a auxiliar de engenharia, os estagiários, o almoxarife, o auxiliar de almoxarife, dois mestres de obra, o encarregado de elétrica e o de hidráulica, e alguns ajudantes. Todos os outros serviços eram subempreitados.

Contudo, durante o andamento da obra, a construtora passou a contratar boa parte dos operários - os mesmos operários que antes eram subempreitados. Segundo depoimento do estagiário, a empresa queria ter total responsabilidade sobre os funcionários. Quando os trabalhadores eram contratados diretamente pela construtora deveriam seguir os horários e as regras da empresa e não as regras do subempreiteiro. 0 estagiário comentou que muitos operários chegavam tarde à obra, por exemplo, e justificavam que haviam combinado isso com o subempreiteiro. 
Em relação à gestão de funcionários, para o estagiário a mudança foi positiva, uma vez que a construtora teria mais controle sobre os trabalhadores. Em contrapartida, o salário seria menor do que recebiam antes. Perguntei o que os operários estavam achando da nova contratação: "Agora eles tão gostando, porque ainda não receberam o primeiro salário..." 59. Esse processo de contratação acabou atrasando o andamento da obra, uma vez que os funcionários precisaram ser demitidos e recontratados em um novo regime. 0 engenheiro disse que esta mudança foi uma inovação dentro do canteiro e que nessa obra não houve nenhum problema decorrente disso.

Os funcionários que foram contratados diretamente pela empresa eram os responsáveis pelos serviços de alvenaria, massa interna e externa, contrapiso e colocação de portas e janelas. Os serviços de pintura, fabricação das lajes, assentamento de cerâmica, elétrica e hidráulica e infraestrutura das áreas livres ainda eram subempreitados.

Antes da mudança, a construtora contava com apenas um pedreiro contratado dentro do canteiro. Depois, eram 65 trabalhadores diretamente contratados, entre pedreiros e serventes. Entre estes 65 funcionários existiam os 'bloqueiros', como eram chamados os trabalhadores responsáveis pelo assentamento dos blocos de alvenaria estrutural. Os serventes tinham a função de auxiliar os bloqueiros, transportando materiais e preparando argamassa e concreto. Ainda existiam, contudo, cerca de 200 trabalhadores subempreitados que realizavam serviços de hidráulica, elétrica, gesso, azulejo, etc.

Durante a pesquisa anterior realizada pela orientadora deste projeto, também com a Empresa Nacional, ocorreu o mesmo processo. Inicialmente, eram contratados diretamente pela construtora apenas os trabalhadores mais especializados. Algum tempo depois, a empresa começou a contratar diretamente grande parte dos trabalhadores.

59 Fala do estagiário. 
Três meses depois de iniciada a pesquisa, [...] a ECP começou a contratar cada vez mais trabalhadores, até passar a ter aproximadamente 60\% de trabalhadores presentes na obra - a "equipe própria", como falam no canteiro. (SHIMBO, 2012, p. 159)

Shimbo (2012) observou essa mudança nos canteiros da Nacional no ano de 2008. $\mathrm{Na}$ época, a empresa afirmava que esta era uma tendência que buscava reduzir ou até mesmo eliminar a subempreita de suas obras. Alguns fatores eram apontados como motivadores dessa estratégia, como a busca pela qualidade dos serviços executados - que muitas vezes ficava aquém do esperado nas mãos dos subempreiteiros - e também do alto valor praticado pelos subempreiteiros na época. 0 preço elevado cobrado pelas subempreiteiras tinha a ver com o momento de boom imobiliário no Brasil, que ocorreu justamente naquele momento. A demanda elevada e a escassez de mão de obra incentivavam os subempreiteiros a subir o preço dos serviços.

Por outro lado, essa garantia de demanda também encorajava as construtoras a contratar diretamente seus trabalhadores, uma vez que a chance dos trabalhadores ficarem ociosos era bem menor. Além disso, a Nacional, nessa época, havia aberto seu capital (como veremos no capítulo seguinte), e precisava aumentar sua produtividade como uma garantia aos investidores. Dessa maneira, não seria interessante depender exclusivamente das subempreiteiras (SHIMBO, 2012).

Alguns anos depois, em 2014, nos deparamos novamente com situação similar no estudo do canteiro do ALV_APTO. A Nacional havia optado, no decorrer da obra, por contratar diretamente boa parte dos operários antes subcontratados.

Apesar de o estagiário afirmar que o novo regime de contratação tinha a ver apenas com a gestão dos trabalhadores, foi possível presumir que a mudança observada no canteiro do ALV_APTO tinha relação com um Termo de Ajusta de Conduta (TAC) que a construtora assinou com o Ministério Público do Trabalho (MPT) na época ${ }^{60}$. Nesse termo, a Empresa Nacional se comprometeu a contratar diretamente alguns serviços do canteiro de obra. A construtora foi autuada devido a irregularidades nas

60 Em 2013 a Empresa Nacional e o Ministério Público do Trabalho (MPT) firmaram um acordo no qual a construtora se comprometia a contratar diretamente parte dos serviços das obras, exatamente como foi observado na obra do ALV_APTO. Revista Consultor Jurídico, 2013, Acesso em novembro de 2017. 
condições de trabalho em algumas de suas obras e também já integrou a lista suja no cadastro de exploradores de trabalho escravo. As empresas que figuram na lista suja são obrigadas a cumprir pesadas restrições comerciais e, portanto, era de interesse da Nacional retirar seu nome da lista o quanto antes.

O MPT entende que a terceirização das atividades da construção frequentemente está relacionada à precarização do trabalho e às irregularidades trabalhistas. Dessa maneira, obrigar as empresas a contratarem diretamente ao menos parte dos serviços da obra é uma estratégia para coibir as práticas irregulares.

As obras mais recentes observadas em nossa pesquisa de campo, entretanto, voltaram a apresentar o padrão da subempreitada, sendo que a Empresa Nacional contratava diretamente apenas os funcionários da equipe técnica. É importante ressaltar que nos últimos meses o governo federal afrouxou as leis trabalhistas. É provável que esse fator colabore para que a ICCSE apresente um retrocesso no que diz respeito às condições de trabalho nos canteiros de obra.

\subsection{Controle técnico do trabalho}

Dentro dos canteiros de obras, o trabalho era diariamente controlado pelo engenheiro, mestre de obra, estagiários e auxiliares. No caso da obra do ALV_APTO, por exemplo, eram dois engenheiros. Um deles ficava mais no escritório resolvendo questões de projeto e o outro era responsável pelo canteiro. Os estagiários, os mestres de obra e os auxiliares também eram responsáveis por realizar medições na obra e conferir a produção dos pedreiros. Como a obra estava sendo construída em três módulos, existiam muitas etapas de construção acontecendo concomitantemente. 0 engenheiro era responsável, portanto, desde o pedreiro que estava executando a alvenaria em um bloco, até o gesseiro que estava fazendo acabamento em outro bloco.

Havia grande rotatividade dos trabalhadores do canteiro, entretanto a equipe técnica praticamente não mudava durante toda a obra. A Empresa Nacional controlava os horários de entrada e saída e de café dos trabalhadores. Logo na entrada da obra, existia um quadro com essas informações, bem como informações de exigência de uso de Equipamentos de Proteção Individual (EPI's). Quem 
controlava a entrada e a presença dos trabalhadores no canteiro era o porteiro, com auxílio de um sistema de controle não informatizado. Ele anotava as faltas de cada funcionário, sendo que a partir de três faltas, o funcionário deixava de ganhar a cesta básica. Desde as primeiras visitas ao ALV_APTO estava prevista, a implantação de um sistema de cartão para realizar um controle mais rigoroso dos funcionários, contudo, até o momento tal mudança não havia sido implementada. Os porteiros eram funcionários de uma empresa especializada em portarias.

Nas obras da Empresa Regional os trabalhadores responsáveis pelas paredes de concreto tinham certa autonomia em relação ao horário de trabalho. Tecnicamente eles deveriam entrar às $7 \mathrm{~h}$ e sair às $17 \mathrm{~h}$, porém, geralmente preferiam começar bem mais cedo para concluir o serviço o quanto antes. No dia de uma das visitas, por exemplo, em torno das $11 \mathrm{~h}$ eles já estavam finalizando a montagem das formas. Assim que a concretagem fosse concluída, eles já estariam liberados. 0 engenheiro disse que no meio da tarde já costumam estar 'de banho tomado' e que às vezes é preciso controlar o horário dos operários, caso contrário eles trabalhavam desde muito cedo para poderem descansar durante a tarde, quando é mais calor. Evidentemente que essa jornada alternativa só é possível porque os trabalhadores ficam alojados dentro do próprio canteiro de obras.

Em nenhuma das obras analisadas foi possível observar sistemas informatizados de controle de entrada e saída dos trabalhadores. Geralmente esse processo era realizado manualmente, na portaria das obras. Já no canteiro do PC_CASA_1 alguns trabalhadores faziam o controle de ponto.

Apesar do controle do trabalho em si não ser realizado com base em nenhum sistema informatizado, a Empresa Nacional se utilizava de um software para todo seu processo de compras e controle de materiais, o 'Nacional Obras'. De certa maneira, esse sistema representava uma forma de controle inclusive sobre os trabalhadores de maior hierarquia na obra, no caso os engenheiros, os mestres e almoxarifes.

Em sua pesquisa anterior, inclusive, Shimbo (2012) detectou que estes três cargos representavam a estrutura de controle da Empresa Nacional nas obras, o que a autora chamou de 'tripé da obra'. 
Esse tripé responde ao maior nível hierárquico internamente ao canteiro, e é responsável, perante a empresa construtora, pelo andamento da obra. São os 'controladores' do canteiro e realizam a intermediação necessária entre empresa e obra. No entanto, esses controladores são controlados, não apenas pela hierarquia imediatamente superior a eles - engenheiro-supervisor, coordenador de almoxarifes, coordenador de mestre de obras, superintendente de produção, diretor da empresa -, mas também pelo sistema on-line de controle. Talvez aqui esteja uma das novidades principais trazidas pela organização do canteiro de obras da ECP (SHIMBO, 2012, p.165).

Foi possível observar que tal estrutura ainda se mantém nos canteiros de obras da Empresa Nacional, e o 'Nacional Obras' - ou o sistema on-line de controle - continua tendo papel fundamental no gerenciamento dos canteiros. Vale acrescentar que além do 'tripé', outros personagens da equipe técnica exerciam também o controle sobre os operários das obras, no caso alguns estagiários e auxiliares de engenharia. 0 controle exercido por este instrumento informatizado se dava a partir da compra de materiais e insumos. Cada material era comprado dependendo do estágio da obra, mas sempre levando em conta a programação do fornecedor. Ou seja, se determinado material demorasse um mês para chegar, a compra deveria ser feita um mês antes de o produto ser utilizado.

Os materiais só podiam ser comprados nos períodos abertos pela janela de compras da empresa nacional. A partir desse sistema, a pessoa responsável pela compra tem, geralmente, dois períodos por mês para realizar os pedidos. A primeira janela de compras durava cerca de sete dias e a segunda, três dias. Fora desses períodos, o sistema não permite pedidos de materiais. Portanto, é necessário um controle rigoroso por parte da equipe de engenharia e do almoxarife no sentido de evitar uma eventual falta de materiais na obra.

Não há contato direto com o fornecedor de materiais, tudo é feito pelo sistema e quem faz as compras efetivamente, é o pessoal da central de Ribeirão Preto. Contudo, o responsável pelas compras na obra tem conhecimento sobre os fornecedores e às vezes é possível negociar prazos e entregas. Por exemplo, o fornecedor de hidráulica é a TIGRE. Se por qualquer motivo estiver faltando algum material de hidráulica na obra e a janela de compras estiver fechada, o responsável tenta negociar com o fornecedor para que ele envie o produto e só depois, quando a janela de compras for aberta, ela passa o pedido. De acordo com a auxiliar de engenharia do ALV_APTO, que era a responsável por essa tarefa, é "necessário ter jogo de cintura e saber negociar com os fornecedores", pois é difícil conciliar o 
período de compras com o exato controle dos materiais que precisam ser comprados.

Todos os fornecedores são fechados pela equipe de suprimentos, da central de Ribeirão Preto e normalmente eram grandes distribuidoras. Alguns materiais, inclusive, vinham de longe, do nordeste ou de Minas Gerais. 0 gesso, por exemplo, vinha de Pernambuco e as janelas, de Belo Horizonte. A maior parte dos equipamentos e máquinas era alugada em Ribeirão Preto. Alguns equipamentos e ferramentas de trabalho eram comprados pela própria construtora, como enxadas, pás, discos, esquadros, réguas, níveis, pás de pedreiro, etc.

Caso houvesse necessidade de comprar algum material na cidade de São Carlos, por exemplo, a empresa nacional disponibilizava um valor mensal de $\mathrm{R} \$ 6.000,00$, o que eles chamavam de compra em depósito. 0 engenheiro passava o pedido para o almoxarife, que fazia a requisição da compra. Apenas três lojas são liberadas pela central para essas compras na cidade. Essa compra também é feita a partir do programa 'nacional obras'. Era necessário escolher o material e o bloco (de apartamentos) em que ele vai ser utilizado, além do elemento (hidráulica, elétrica, etc.) e da atividade (se o elemento for hidráulica, por exemplo, era necessário informar se é um material de esgoto, ou água fria, ou água quente, etc.). Esse processo também era realizado para as compras gerais dentro do período da janela de compras, mas nesse caso, era necessário que o pedido passasse pela aprovação da engenheira de controle, que poderia questionar o pedido, dependendo do preço. O almoxarife do ALV_APTO deu um exemplo de quando precisaram comprar discos de corte. Ele sabia que os discos em uma loja da cidade custavam $\mathrm{R} \$ 8,00$ cada. Como eram utilizadas cerca de dez unidades por dia, ele pediu a auxiliar que fizesse um pedido de 300 discos, para durar um mês. Geralmente, o preço da distribuidora é mais barato que o preço da loja da cidade. Contudo, nesse caso, o preço da distribuidora que estava no sistema da nacional, era próximo de $\mathrm{R} \$ 25,00$ por disco. Ou seja, no fim, foi gerado um valor muito alto para ser gasto com discos. A engenheira de controle notou a discrepância e questionou o pedido. Nesses casos, era discutida com o engenheiro a necessidade real da compra. Se o engenheiro insistisse na compra, o pedido ainda deveria ser aprovado pelo coordenador da regional. Caso ele também não aprovasse, era necessário que o engenheiro e o 
coordenador entrassem em acordo. No entanto, essa situação era bastante improvável nesta obra.

O controle em relação à entrega dos materiais era feito a partir do procedimento de qualidade ISO 9001. Geralmente o responsável por esse serviço era o almoxarife. Ele tinha um controle dos materiais que estavam pendentes e atrasados. Todos os pedidos ficavam no sistema on-line, mas geralmente ele imprimia e organizava tais pedidos em uma pasta de entregas pendentes ou atrasadas.

Fica claro que o sistema informatizado tem certa rigidez em seu funcionamento, provavelmente como uma forma de impor ritmo e controle às obras. Por outro lado, como foi possível notar pelo depoimento da auxiliar de engenharia, não era incomum que as equipes burlassem o sistema em certos momentos.

Além da questão da compra de materiais, o 'Nacional Obras' tinha papel fundamental sobre a gestão das obras de modo geral. Os engenheiros alimentavam o sistema com informações detalhadas sobre o andamento das obras, previsões, medições, etc. e dessa maneira, acabavam sendo controlados por ele também.

Uma estratégia que a Empresa Nacional utilizava como forma de controle era justamente o ranking das obras. Através das informações disponibilizadas pelo tripé da obra, era medido o desempenho da equipe e traçado um quadro comparativo em relação a outras obras. 0 resultado desse desempenho era apresentado no próprio canteiro de obras, no 'Farol da Qualidade', que discriminava uma série de atividades e o respectivo desempenho da equipe da obra. Dessa maneira, ficava explícito para todos os trabalhadores quais atividades estavam satisfatórias e quais deveriam ser melhoradas. 


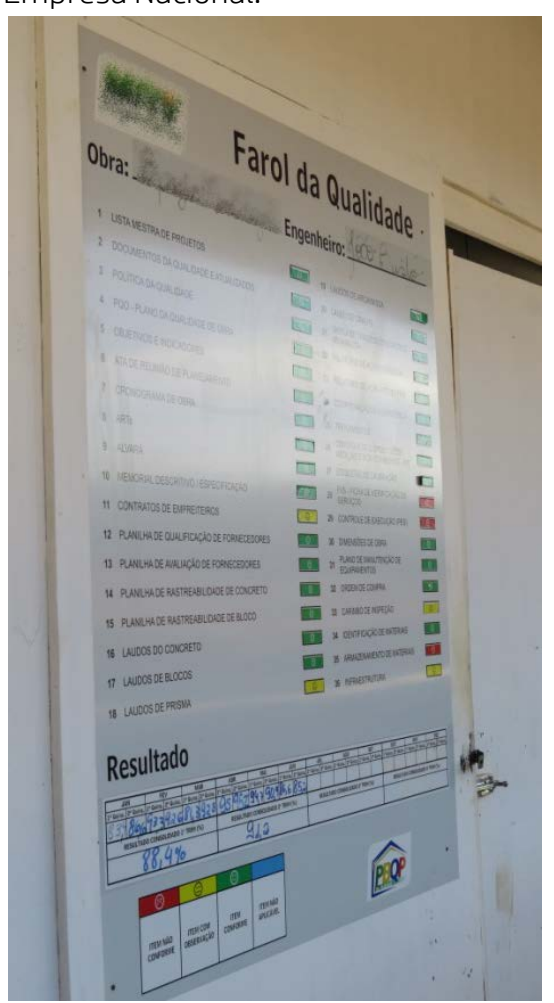

FONTE: Acervo da autora, 2014.

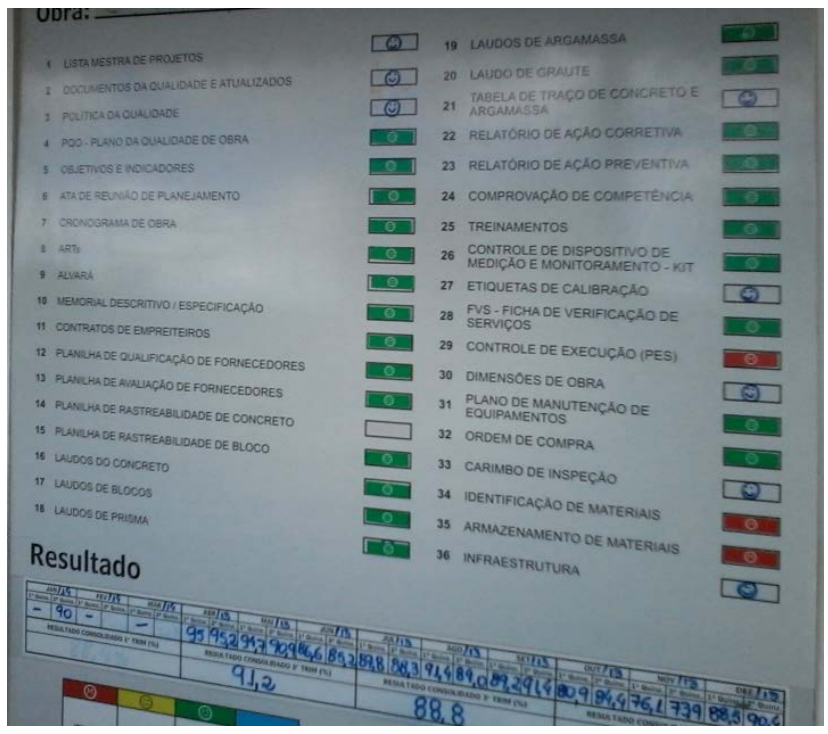

O desempenho era medido a partir de quatro níveis: item não conforme; item com observação; item conforme; item não aplicável. A linguagem utilizada no painel era, inclusive, bastante direta, utilizava cores e símbolos para ilustrar os resultados. 0 Farol da Qualidade tinha bastante efeito, inclusive sobre o trabalho do engenheiro, uma vez que expunha, de certo modo, seu desempenho pessoal como principal gestor da obra.

Na época da obra do ALV_APTO, eram 36 itens analisados. Dentre eles, apenas três serviços não estavam conforme: o 'FVS - Ficha de verificação de serviços'; o 'Controle de Execução - PES'; e o 'Armazenamento de Materiais'. Alguns outros estavam com observações e o restante estava conforme. Mesmo assim, essas falhas representavam uma piora no desempenho da obra, e o engenheiro estava preocupado em melhorar esses serviços.

É notável, portanto, que a Empresa Nacional desenvolveu uma estratégia de controle que começa com a hierarquia máxima da obra - o tripé, identificado por Shimbo (2012). Esses funcionários, por sua vez, alimentam um sistema informatizado que traça o perfil e o desempenho de cada obra. Por ser utilizado em todas as obras da 
construtora, o 'Nacional Obras' possibilita uma análise comparativa de desempenho, o que por si só já é uma forma de induzir a 'concorrência' entre seus próprios engenheiros. Evidentemente, as equipes que alcançam melhor desempenho são reconhecidas pelas instâncias superiores da empresa, inclusive por meio de bonificações.

Shimbo (2012), na época de sua pesquisa caracterizou o sistema on-line de controle como uma importante inovação trazida pela Nacional para dentro dos canteiros de obras. Alguns anos depois, é possível perceber que esse sistema está muito consolidado nas obras, e tem papel fundamental dentro dos canteiros. Inclusive, representa uma diferença expressiva entre as duas empresas aqui analisadas. A Empresa Regional não trabalha com um sistema similar.

Nos canteiros da Regional, foi possível observar que o controle mais expressivo é realizado pelos engenheiros, pelo mestre de obras e pelos estagiários e auxiliares. Para além do controle direto sobre os operários, todo o controle de gestão da obra era realizado através de planilhas e indicadores, mas não através de um sistema completo, como era o caso da Nacional.

De qualquer maneira, a Empresa Regional também expunha em seus canteiros, o desempenho da obra e os objetivos e metas e também o calendário com as auditorias internas. Existiam inclusive, alguns gráficos comparativos entre algumas obras da empresa.

Apesar de existir uma diferença considerável no que diz respeito ao sistema construtivo utilizado pelas duas empresas, foi notável que a preocupação com o controle sobre o desempenho das obras era um fator de grande importância para as duas empresas. Esse tipo de controle representa aumento na produtividade, uma clara estratégia de racionalização da produção.

\subsection{Os salários e bonificações por produtividade}

Além do controle explícito sobre os trabalhadores, uma estratégia utilizada pelas empresas para garantir a produtividade desejada era pautada por incentivos financeiros aos operários. Essa estratégia explicita algumas variações nos modelos de contratação que podem ser identificados nos canteiros de obras. Em sua pesquisa 
Shimbo (2012) já havia destacado que existiam diversas modalidades de contratação dos trabalhadores na Empresa Nacional: "o salário fixo; ii) o salário + produção; iii) o salário + produção + gratificação; iv) e o salário + serviços extra" (SHIMBO, 2012, p.189).

Na obra do ALV_APTO, o salário dos pedreiros dependia da produtividade. Eles ganhavam aproximadamente $\mathrm{R} \$ 1.200,00$ fixos. Se atingissem determinada meta, ganhavam adicional que podia chegar até $50 \%$ do salário fixo. Os engenheiros recebiam entre $R \$ 6.000,00$ e $R \$ 7.000,00$. Os mestres de obra, entre $R \$ 3.000,00$ e $\mathrm{R} \$ 4.000,00$. 0 estagiário nível 1 ganhava $\mathrm{R} \$ 850,00$ e o nível 2, $\mathrm{R} \$ 1.130,00$. De acordo com informações do SINDUSCON, o piso salarial para a função de pedreiro era de $\mathrm{R} \$ 1.055,13$ e o de mestre de obra, $R \$ 2.311,42$. Isso significa que, de uma forma geral, os salários oferecidos pela construtora estavam um pouco acima do piso da categoria. 0 fato é que esse formato de pagamento de bônus por produtividade, efetivamente é uma forma de controle do trabalho, uma vez que o incentivo salarial induz os trabalhadores a melhorarem o próprio desempenho.

No PC_CASA_2, todos os trabalhadores responsáveis pelas paredes de concreto eram diretamente contratados pela Empresa Regional. A empresa também se utilizava da estratégia de bonificação por produção. Cada um desses funcionários recebia um salário fixo de aproximadamente $\mathrm{R} \$ 1.600,00$ e mais um adicional por produtividade de $\mathrm{R} \$ 60,00$ por casa produzida. 0 "líder" de cada grupo de trabalhadores (que é um trabalhador escolhido pelo engenheiro para conduzir e gerenciar o processo de montagem e concretagem das casas) tem o mesmo salário fixo, porém recebe um adicional maior, de $\mathrm{R} \$ 90,00$ por casa. 0 engenheiro afirmou que, apesar do adicional ser medido por casa produzida, os trabalhadores não deveriam executar mais de uma montagem por dia. Desse modo, o salário total de cada operário chegava a aproximadamente $\mathrm{R} \$ 2.800,00$ por mês, sendo que o líder chegava a receber em torno de $\mathrm{R} \$ 3.400,00$. Comentei que era um bom salário e o engenheiro afirmou que era importante para a empresa segurar os melhores operários, por isso ofereciam boa remuneração. Além do pagamento em dinheiro, todos os trabalhadores tinham direito ao alojamento (que ficava dentro da obra) e a quatro refeições por dia - café da manhã (leite, suco, um pão com manteiga e um pão com frios), almoço (refeição 
completa montada por nutricionista), café da tarde (pão com frios, frutas, suco de frutas) e jantar.

As bonificações por produtividade foram observadas, portanto, nas obras de ambas as empresas analisadas. Representam uma forma de incentivo para que o trabalhador aumente sua jornada de trabalho ou para que produza mais em menor intervalo de tempo. É evidente que tal estratégia tem impacto direto sobre o operário. Reproduzo aqui, a ponderação feita por Shimbo (2012) acerca dessa questão.

Ao parcelar a remuneração do trabalho, numa parte fixa - registrada e tributada - e em outra parte variável, a depender da produtividade e do empenho do trabalhador - não tributada -, a empresa ganha duplamente. 0 primeiro ganho diz respeito à parte repassada ao trabalhador que não é contabilizada como salário, não incidindo impostos sobre ela. 0 segundo, muito mais complexo, tem a ver com a questão do controle e da própria exploração do trabalhador. Sob a alegação de uma remuneração melhor, a ser calculada tanto pela quantidade de trabalho produzido ou pelo cumprimento das metas de prazo e custo, tanto o tripé da empresa no canteiro, como os demais trabalhadores são "motivados" a trabalharem "mais" em um tempo menor ou estendendo a jornada de trabalho; nesse último caso, repondo o tradicional serão (SHIMBO, 2012, p. 193). 


\section{CAPÍTULO 4}

Da alvenaria estrutural às paredes de concreto

As paredes de concreto conformam um sistema estrutural executado a partir de fôrmas utilizadas para a concretagem de paredes e lajes diretamente em sua respectiva edificação. Uma pequena reportagem intitulada "Habitação seriada" apresenta o sistema construtivo de paredes de concreto que vinha sendo empregado justamente em grandes empreendimentos habitacionais voltados ao mercado de baixa renda ${ }^{61} .0$ engenheiro de projetos da OSMB, Thales Couto Braguim, afirma que desde 2007 a utilização das paredes de concreto em obras voltadas ao segmento econômico é crescente. Um dos motivos para tal expansão é o ganho de experiência por parte das construtoras em relação ao processo de projeto voltado para este sistema construtivo. Braguim coloca também como uma questão chave para a implementação desta tecnologia, o elemento da repetição, completamente presente nos empreendimentos para baixa renda. 0 engenheiro, entretanto, demonstrou otimismo em afirmar que as paredes de concreto poderão em breve ser opção também para os empreendimentos de médio e alto padrão. 
Esses mercados têm como característica serem mais personalizados, mas, mesmo assim, o índice de repetição num pavimento-tipo, por exemplo, é alto. A construção desses pavimentos em paredes de concreto seria muito mais veloz em comparação a uma estrutura convencional. Talvez o impeditivo para que isso ainda não ocorra em maior escala seja o alto custo inicial das fôrmas. Mas é importante lembrar que as formas de alumínio e de aço tem vida útil longa. (ANUÁRIO DA CONSTRUÇÃO, 2014, p.130)62.

Duas das obras estudadas que foram executadas com paredes de concreto eram da mesma construtora, a Empresa Nacional. Desde meados de 2010 a construtora estudava a implementação deste sistema construtivo, e vinha realizando alguns testes. Até recentemente, a Nacional executava seus empreendimentos majoritariamente em alvenaria estrutural. Durante uma visita a um dos canteiros o PC_APTO_2 - o auxiliar de engenharia afirmou que levou um tempo até a construtora de fato conseguir viabilizar o sistema. Inicialmente, foram realizados testes em empreendimentos na cidade de São Paulo e em seguida, uma tentativa no interior, em Ribeirão Preto. 0 auxiliar disse ainda que naquela oportunidade não houve uma grande vantagem na utilização da tecnologia das paredes de concreto e, por isso, esta estratégia acabou ficando adormecida por um tempo. Em 2011, a Nacional justamente publicou em seu blog a estratégia em implementar o sistema de paredes de concreto como uma maneira de aumentar a produtividade.

\begin{abstract}
A 'Empresa Nacional' também utiliza a alvenaria estrutural para otimizar custos na construção de imóveis para a baixa renda. Com o método, a empresa garante maior velocidade e facilidade de construção, maior produtividade por operário, melhor controle orçamentário, alta durabilidade e baixa manutenção. Paralelamente, a companhia está testando outros métodos construtivos para obter ganhos de produtividade, a exemplo da parede de concreto, laje pronta (içada) e estruturas pré-moldadas. A empresa desenvolveu ainda um software (Nacional obras) que é utilizado em todas as obras da companhia, para controlar as compras, medição de tarefas, o cronograma da obra e o estoque de cada material. (BLOG da Construtora, 2011)
\end{abstract}

Até 2010 a construtora utilizava massivamente a alvenaria estrutural, que era inclusive uma estratégia de marketing da empresa. Em uma reportagem da época, a Empresa Nacional apresentava a alvenaria estrutural como um sistema construtivo sustentável, pois, sendo um sistema autoportante, não há necessidade de executar vigas e pilares - como nas construções chamadas convencionais - e desse modo, 
exclui-se também a utilização das formas de madeira. Além disso, os projetos também eram 'paginados' e os blocos não precisavam ser quebrados, uma vez que já chegavam ao canteiro nas dimensões que seriam utilizados ${ }^{63}$.

Provavelmente a construtora aperfeiçoou o processo e o sistema construtivo, porque atualmente muitas de suas obras já estão sendo executadas com as paredes de concreto. Em entrevista à revista TECHNE, o gestor-executivo da regional São Paulo da Empresa Nacional afirmou que é interessante que a empresa trabalhe com os dois sistemas construtivos: alvenaria estrutural e paredes de concreto. Segundo ele, a utilização das paredes de concreto vem seguindo em uma crescente, porém, até por uma questão de especificidades regionais, não é interessante que a construtora abandone a alvenaria estrutural - além do fato da Nacional ter esta tecnologia muito consolidada.

A Empresa Regional também adotou as paredes de concreto em suas obras e os empreendimentos recentes da construtora foram executados a partir desse sistema. Através de uma parceria com uma grande construtora atuante principalmente no nordeste, a Regional passou a utilizar as fôrmas de alumínio em suas obras. Em linhas gerais, a grande construtora auxiliou na adoção do novo sistema, inclusive em termos financeiros, e a Regional possibilitou sua entrada na produção do interior do estado de São Paulo.

Durante a pesquisa de campo, foi possível acompanhar ambos os processos construtivos, compreender suas particularidades e observar as estratégias utilizadas pelas construtoras durante as etapas de execução. Apresentaremos a descrição da execução da alvenaria estrutural e das paredes de concreto. Em seguida, traremos as análises sobre os dois sistemas e a discussão sobre crescente utilização das paredes de concreto nos empreendimentos habitacionais de larga escala.

${ }^{63}$ Site da construtora. Acesso em ago/2017. 


\subsection{Alvenaria estrutural}

Dentre todos os empreendimentos estudados, apenas um deles foi executado em alvenaria estrutural, o ALV_APTO, da Empresa Nacional. Esse canteiro foi visitado durante uma pesquisa anterior de Iniciação Científica entre 2012 e 2014. Trata-se, portanto, de uma oportunidade de construir uma análise comparativa entre a produção atual e a produção menos recente da empresa.

A Nacional está gradualmente substituindo a utilização da alvenaria estrutural em suas obras por paredes estruturais de concreto moldadas in loco. Por esse motivo, parece pertinente discutir os aspectos da produção realizada em alvenaria estrutural e assim perceber o que levou a construtora a esta mudança tão substancial em seu processo produtivo.

O emprego da alvenaria estrutural cresceu consideravelmente no Brasil desde os anos 2000. Isto porque esse sistema construtivo pode ter vantagens de produtividade, economia e custo em relação a sistemas construtivos convencionais. Um requisito, entretanto, para que essa vantagem seja realmente efetiva é que o projeto executivo esteja bem resolvido e também que a mão de obra esteja capacitada para trabalhar com essa tecnologia. De acordo com o Anuário da Construção de 2014, o interesse das construtoras pela alvenaria estrutural aumentou desde 2010 tanto para utilização em habitação popular, mas também para empreendimentos destinados à classe média.

A explosão do consumo da alvenaria estrutural, contudo, acarretou alguns entraves. Nem sempre o fornecimento do bloco estrutural acompanhou o ritmo da demanda, assim como a mão de obra que, em certos momentos, tornou-se escassa. Tais dificuldades demonstram que o planejamento do processo produtivo é essencial para que esse sistema construtivo realmente seja vantajoso. É indispensável contar com um bom projeto executivo e também com fornecedores de materiais e mão de obra confiáveis.

A alvenaria estrutural tem entre suas vantagens o fator de agrupar em um mesmo elemento estrutura e vedação. Essa característica, por si só, diminui o tempo de produção e elimina algumas etapas construtivas - em relação a sistemas convencionais - como a montagem de fôrmas para estrutura, por exemplo. 
Entretanto, é necessário cuidado com o projeto executivo, uma vez que o desempenho do sistema construtivo é bastante diferente de um sistema convencional de concreto armado, por exemplo. A compatibilidade entre os diversos sistemas que compõem a edificação deve ser cuidadosamente ajustada. Todas as instalações elétricas e hidráulicas precisam estar definidas previamente; os reforços da estrutura - chamados pontos de graute - também precisam ser pensados; deve haver também um cuidado extra com vãos e aberturas.

As paredes estruturais de alvenaria podem ser executadas com blocos de cerâmica e com blocos de concreto. Evidentemente, cada tipo de bloco tem propriedades específicas que devem ser respeitadas. A obra em alvenaria estrutural acompanhada nesta pesquisa foi executada com blocos de concreto, a opção mais comum da Empresa Nacional.

As normas que regem a produção e execução da alvenaria estrutural com blocos de concreto são: 'NBR 15.961-1 - Alvenaria Estrutural - Blocos de Concreto (Projeto)'; 'NBR 15.961-2 - Alvenaria estrutural - Blocos de Concreto (Execução e Controle de Obras)'; 'NBR 6.136 - Bloco Vazado de Concreto Simples para Alvenaria Estrutural'; 'NBR 12.118 - Blocos Vazados de Concreto Simples - Métodos de Ensaio'; 'NBR 8.949 - Paredes de Alvenaria Estrutural - Ensaio à Compressão Simples'; 'NBR 14.321 - Paredes de Alvenaria Estrutural - Determinação da Resistência ao Cisalhamento'; 'NBR 14.322 - Paredes de Alvenaria Estrutural - Verificação da Resistência à Flexão Simples ou à Flexão Composta' (Anuário da Construção, 2014). 
A execução da alvenaria estrutural na Empresa Nacional

Nas obras da Empresa Nacional, a execução da alvenaria estrutural é norteada pelo "PES 07 - Execução de alvenaria estrutural". 0 documento contém 12 páginas de especificações e detalhes minuciosos para o referente serviço. 0 traço ${ }^{64}$ da argamassa de assentamento era definido de acordo com o "PES 35 - Tabela Geral de traços - argamassas - regional”.

0 processo de execução da alvenaria estrutural é iniciado pela preparação do local - organização dos materiais e limpeza - e pela verificação dos resultados dos testes de resistência. Antes desta etapa, contudo, os blocos estruturais são entregues na obra, testados e finalmente transportados dentro do canteiro.

Na obra do ALV_APTO, foram utilizados blocos estruturais de concreto. A empresa fornecedora destes blocos era uma empresa regional, a "Block", de atuação na região de Araraquara e Ribeirão Preto. Trata-se de uma empresa consolidada, com 20 anos de existência. A produção dos blocos é realizada em uma fábrica própria, fora do canteiro de obras. A empresa frisa sua preocupação em manter a qualidade dos blocos e a pontualidade na produção, além disso, se dispõe a desenvolver novos produtos de acordo com as necessidades de seus clientes ${ }^{65}$.

Os fornecedores geralmente se repetem em obras de uma mesma região, portanto, estabelecem uma relação contínua com a construtora.

A argamassa de assentamento e o concreto do graute eram executados na própria obra, em algumas bases de fabricação que eram pequenas coberturas onde ficavam as betoneiras. Próximas a essas bases geralmente ficavam armazenados os agregados - areia e brita - para que não fosse necessário um grande deslocamento dos serventes que transportavam os materiais. 0 transporte da argamassa e do

\footnotetext{
${ }^{64}$ Além do traço, existem algumas observações sobre o processo de execução da argamassa, como 0 cuidado com os tamanhos das padiolas - existem carrinhos de diversos tamanhos, sendo que cada um deles é marcado com uma respectiva cor nas obras da construtora; a não utilização de areia comum nas argamassas; tempo mínimo para mistura na betoneira, que é de 5 minutos; e outros detalhes sobre tipos de insumos.

65 Informações coletadas no site da empresa "Block" <http://www.arablock.com.br/site/>. Acesso em: fev. 2017.
} 
concreto do graute era feito com carrinhos de mão. Para assentar os blocos, poucas ferramentas eram utilizadas, como colher, prumo, nível, marreta e régua.

A execução dos blocos de apartamentos era iniciada com as fundações, no caso, estacas rotativas e tubulão. Depois de feitos a fundação e o baldrame, eram passadas as mangueiras de instalações elétricas e as esperas para as instalações hidráulicas que ficariam embutidas na alvenaria estrutural (Imagem 63). Para que fosse iniciada a elevação da alvenaria era realizada a marcação da primeira fiada, já prevendo as aberturas das portas e janelas. Em seguida, os bloqueiros começavam a assentar os blocos de concreto, embutindo os conduítes das instalações elétricas (Imagem 64).

Terminada a elevação do primeiro pavimento, na última fiada era executada uma canaleta grauteada para amarração das paredes (Imagem 65). Aí então as lajes já podiam ser instaladas. Eram lajes pré-moldadas, apoiadas sobre as paredes de alvenaria estrutural (Imagem 66). Os vãos entre a laje e alvenaria eram preenchidos com graute. Como todos os condutores necessários já eram colocados nas lajes antes da concretagem não era necessário quebrar alvenaria ou as lajes para a passagem de qualquer tipo de instalação. 0 pavimento subsequente só era iniciado depois da colocação das lajes e da construção das escadas. Para a execução dos pavimentos superiores, era instalado um tubo vertical externo à edificação para que os entulhos fossem descartados de forma rápida e segura.

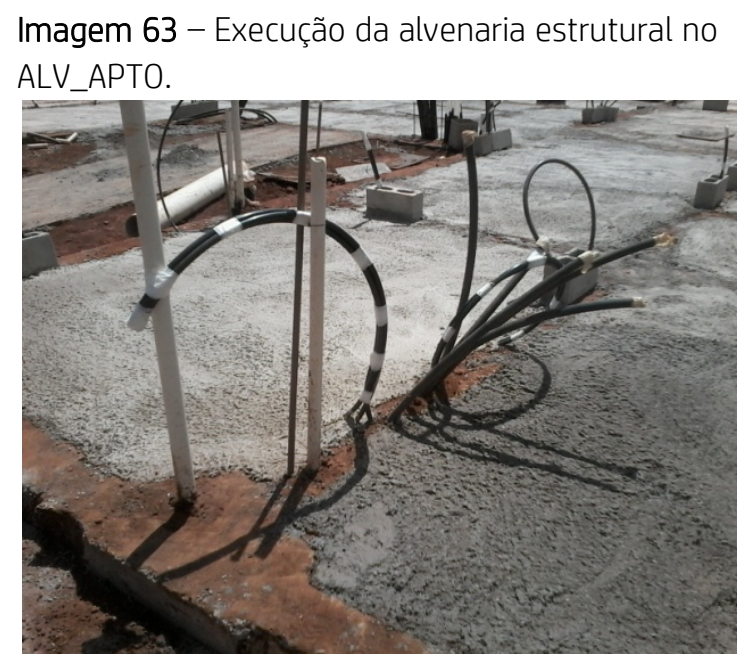

FONTE: Acervo da autora, 2014.
Imagem 64 - Execução da alvenaria estrutural no ALV_APTO.

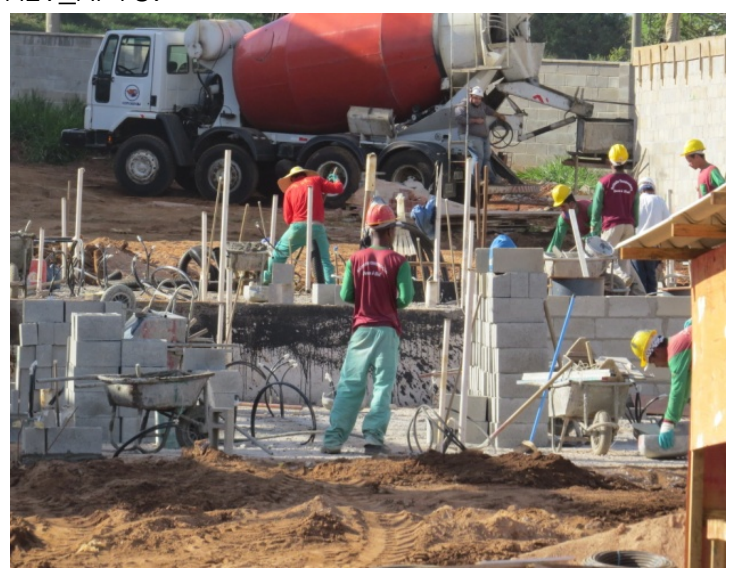

FONTE: Acervo da autora, 2013. 
Imagem 65 - Execução da alvenaria estrutural no ALV_APTO.

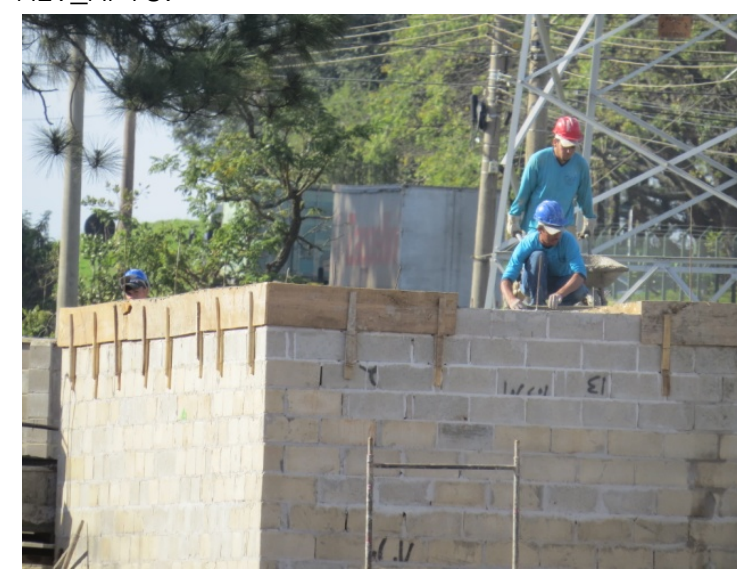

FONTE: Acervo da autora, 2013.
Imagem 66 - Execução da alvenaria estrutural no ALV_APTO.

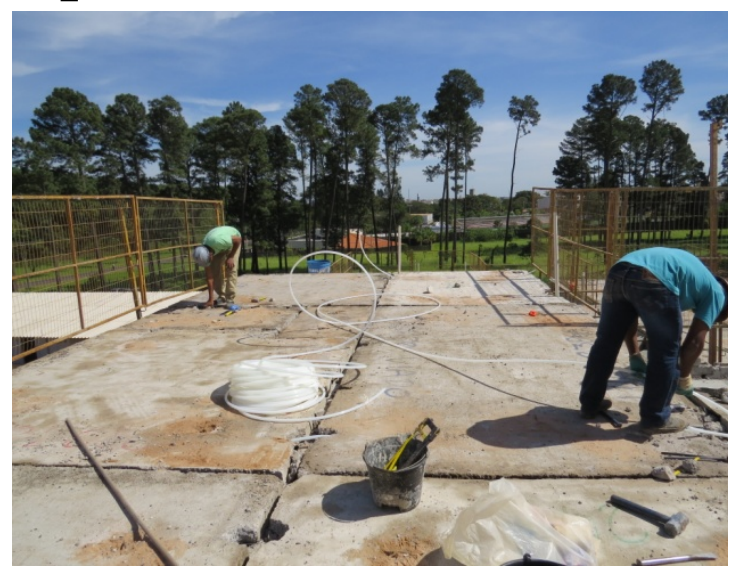

FONTE: Acervo da autora, 2014.

\subsection{As paredes de concreto}

Dentre os cinco empreendimentos estudados, quatro foram executados com sistema estrutural de paredes de concreto e, vale ressaltar, os quatro mais recentes. Por diversos critérios aqui já colocados, foram escolhidos esses quatro canteiros para as visitas, porém, durante o levantamento de empreendimentos potenciais para estudo foi possível observar que existe uma tendência na utilização das paredes de concreto nesse tipo de produção.

\section{Fôrmas de alumínio}

A execução das paredes de concreto moldadas dentro do canteiro de obras depende, naturalmente, de fôrmas. Segundo o Anuário da Construção de 2014, no Brasil existem três tipos de fôrmas: as metálicas (de aço ou alumínio); as metálicas com compensado; e as de plástico reciclável. Evidentemente, cada material exige um tipo diferente de manuseio e tem custo e durabilidade também distintos. Dentre vantagens e desvantagens, as fôrmas metálicas apresentam maior durabilidade em relação às fôrmas de compensado e de plástico. Em contrapartida são mais caras (em valor absoluto) e mais pesadas (ANUÁRIO DA CONSTRUÇÃO, 2014).

De acordo com uma reportagem da revista "Construção Mercado" de 2011, o metro quadrado das fôrmas de alumínio custava cerca de $\mathrm{R} \$ 900,00$. 0 gerente da empresa Mills - que inclusive era a empresa fornecedora das fôrmas para as obras da 
Regional - afirmou que um jogo de fôrmas para concretagem de dois apartamentos já com núcleo e escada custava aproximadamente $\mathrm{R} \$ 360$ mil e a fabricante garantia no mínimo mil utilizações. Considerando-se esses dados, com um investimento inicial de $\mathrm{R} \$ 360$ mil seria possível executar pelo menos 2.000 unidades. 0 custo diluído seria, portanto de $\mathrm{R} \$ 180,00$ por unidade, o que significa que a larga escala de produção faz com que o valor relativo das fôrmas seja consideravelmente baixo. Não foi possível aferir nas obras analisadas quanto custaram as respectivas fôrmas ${ }^{66}$.

O projeto de fôrmas deve ser bastante detalhado, principalmente em relação ao processo de montagem e desmontagem, além de prever equipamentos, escoramentos e peças de travamentos. 0 projeto arquitetônico por sua vez, deve seguir uma modulação e preferencialmente optar por "geometria simétrica e paredes alinhadas" (ANUÁRIO DA CONSTRUÇÃO, 2014).

Outra reportagem do Anuário da Construção de 2014, que leva o título sugestivo "Paredes repetitivas", traz o passo a passo para a execução do referido sistema. Resumidamente, as instruções são: a fundação (que geralmente é radier) deve estar nivelada; em seguida devem ser montadas as telas das armaduras em conjunto com os conduítes e caixinhas das instalações elétricas; deve-se então aplicar o desmoldante nas peças das fôrmas e realizar a montagem, começando pelas peças das faces internas; o próximo passo é executar o travamento das fôrmas com 'gravatas' e cunhas; monta-se então as fôrmas das lajes e sua armação; é feita a concretagem simultânea das paredes e laje; finalmente as fôrmas podem ser retiradas assim que o concreto atinge a cura, mantendo-se apenas alguns escoramentos. E este processo então se repete para todas as unidades.

Trata-se de nove passos bastante simplificados para se explicar a execução de um sistema estrutural. É possível observar que existem dois tipos de processos: a montagem das fôrmas (incluindo a armadura e as instalações) e a concretagem.

66 Debate técnico. "Fôrmas de alumínio". Construção Mercado. Ago/2011. Disponível em: <http://construcaomercado17.pini.com.br/negocios-incorporacao-construcao/121/artigo2825361.aspx>. Acesso em: jun.2018. 
Em todas as obras visitadas executadas com paredes de concreto foram utilizadas fôrmas de alumínio. Os dois empreendimentos de apartamentos executados pela Empresa Nacional eram bastante semelhantes, mas não tinham os mesmos fornecedores de fôrmas. No PC_APTO_1, eram fornecidas pela empresa 'Forza', da Colômbia. De acordo com o engenheiro, essa empresa fornecia assistência em obra durante o primeiro mês da execução e um técnico auxiliava nas primeiras montagens e desmontagens das formas durante um mês. Já no PC_APTO_2, a fornecedora das fôrmas era uma empresa brasileira, a 'SH'. Apesar dos fornecedores distintos, as fôrmas tinham durabilidade similar, em média, 750 concretagens nas obras da construtora. Entretanto, na Colômbia já foi possível realizar 2.000 concretagens com as mesmas fôrmas. A meta da construtora, portanto, é otimizar a utilização das formas para diluir seus altos custos. 0 engenheiro disse ainda que a qualidade das fôrmas da empresa Colombiana é bastante superior às da empresa brasileira.

Na produção das casas térreas também foram utilizadas fôrmas de alumínio fornecidas pela empresa 'Mills'67 - para concretagem in-loco das paredes estruturais e das lajes. A vida útil das formas seria de até 1000 concretagens, porém segundo o engenheiro do PC_CASA_2 dificilmente conseguiriam atingir esta meta, porque exigiria extremo cuidado no manuseio e na manutenção das fôrmas.

Nas obras de edifícios de apartamentos, cada jogo de fôrma é feito para a execução de um pavimento de um bloco, com quatro apartamentos. No PC_APTO_1 existia um jogo de fôrmas disponível, enquanto na obra do PC_APTO_2 eram utilizados dois jogos de fôrmas. Nos empreendimentos de casas térreas, cada jogo de fôrmas era relativo a uma unidade. Na obra do PC_CASA_1, existiam seis jogos, o que permitia a concretagem de até seis unidades por dia. No PC_CASA_2, a construtora tinha à disposição quatro jogos de fôrmas, mas no decorrer da obra nem todos foram utilizados 68 .

\footnotetext{
${ }^{67}$ A Mills é uma empresa brasileira com foco em soluções de engenharia para a construção civil.

68 Inicialmente, o engenheiro estava utilizando todos os jogos de fôrmas, entretanto, o diretor da MC ordenou ao engenheiro que diminuísse o ritmo devido ao repasse da CEF, que estava sendo realizado em parcelas e por isso seria indesejável empregar recurso próprio para executar um serviço que só seria pago
} 


\section{Concreto}

Além das fôrmas, o concreto evidentemente tem papel fundamental para a execução das paredes monolíticas de concreto moldadas in-loco. Nesse sistema construtivo é utilizado o concreto auto adensável, o CAA. Sua diferenciação em relação ao concreto convencional se dá ainda no produto fresco. O CAA é bastante fluido e tem grande deformabilidade, além de elevada estabilidade da mistura. Este tipo de concreto deve, necessariamente, preencher todos os espaços na fôrma; passar por qualquer tipo de restrição; e resistir à segregação. Como o próprio nome já explicita, o concreto auto adensável não demanda utilização de vibrador. Portanto, o CAA é praticamente líquido, e esta plasticidade é atingida através da utilização de aditivos, como superplastificantes e aditivo promotor de viscosidade ${ }^{69}$.

O lançamento do concreto deve ser feito de maneira homogênea para evitar espaços vazios dentro das paredes. $\mathrm{O}$ acerto do traço do concreto é bastante relevante, pois evita algumas patologias comuns, como pequenas fissuras. 0 processo de cura do concreto também auxilia nesse sentido. Para retirada das fôrmas o concreto deve ter atingido a resistência mínima prevista no projeto. Depois da desmontagem é importante que as fôrmas sejam limpas para que sua durabilidade não seja reduzida. Essa limpeza pode ser realizada com jatos d'água ou produtos químicos ou ainda através de instrumentos manuais, como talhadeiras e escovas (ANUÁRIO DA CONSTRUÇÃO, 2014).

O controle tecnológico do concreto é iniciado ainda no canteiro de obras, a partir de testes de fluidez e modelagem dos corpos de prova. A fluidez é aferida no momento do recebimento, através da medição do espalhamento do concreto com auxílio do 'cone de Abrams' (Imagem 70). Basicamente, o concreto é depositado no cone sobre uma base uniforme. Quando o cone é retirado, é medido o diâmetro do espalhamento do concreto. Já os corpos de prova são coletados também no

pela CEF posteriormente. Vale ressaltar que o sistema de pagamento da CEF se dava em relação às etapas da obra comercializadas, por isso o repasse parcial dos pagamentos.

${ }^{69}$ REPETTE, W. "Concreto auto adensável: características e aplicação". Revista Téchne, ed. 135, Jun/2008. Disponivel em: <http://techne17.pini.com.br/engenharia-civil/135/artigo285721-3.aspx>. Acesso em: jun/2018. 
recebimento do concreto (Imagem 67 e 69), mas são enviados para o laboratório, onde é aferida a resistência à compressão (ANUÁRIO DA CONSTRUÇÃO, 2014).

Segundo a NBR 16.055:2012, o concreto para execução das paredes deve ter resistência à compressão com fck entre $20 \mathrm{MPa}$ e 40MPa. É possível perceber que em todas as obras as construtoras utilizavam resistência próxima à mínima exigida pela norma. Geralmente, as construtoras optavam pelo concreto de $25 \mathrm{MPa}$, absorvendo uma margem de segurança, mesmo o mínimo sendo $20 \mathrm{MPa}$.

O tempo e a resistência mínima para cura do concreto e consequentemente para desenforma variavam ligeiramente entre os empreendimentos. Nas obras dos apartamentos, em 12 horas eram necessárias para que o concreto atingisse a resistência de $3 \mathrm{MPa}$. Caso isso não ocorresse era preciso esperar mais tempo para a desenforma. A resistência final do concreto aos 28 dias deveria atingir no mínimo $20 \mathrm{MPa}$. A concretagem ocorria normalmente no final da tarde. Como o tempo de cura do concreto para a desenforma era de aproximadamente 12 horas, se a concretagem fosse executada no final da tarde, já no começo da manhã do dia seguinte as fôrmas podiam ser retiradas e remontadas no pavimento subsequente. Dessa maneira era possível executar a concretagem de um pavimento por dia, considerando-se todas as situações dentro da normalidade. Evidentemente, imprevistos poderiam acontecer e prejudicar esse planejamento, como por exemplo, problemas no fornecimento do concreto, questões climáticas, atraso com a mão de obra, etc.

Nos dois empreendimentos de casas térreas, o primeiro teste do concreto era realizado depois de 14 horas da concretagem. Na obra do PC_CASA_1, a resistência mínima para a desenforma deveria ser de 2 MPa e no PC_CASA_2, 3 MPa para as paredes e $7 \mathrm{MPa}$ para as lajes. A resistência final a ser atingida era a mesma das outras obras, $20 \mathrm{MPa}$, no mínimo. Nas fotos a seguir, é possível observar que o procedimento da preparação dos corpos de prova é bastante similar nas duas construtoras. 
Imagem 67 - Preparação dos corpos de prova no PC_CASA_2-Empresa Regional.

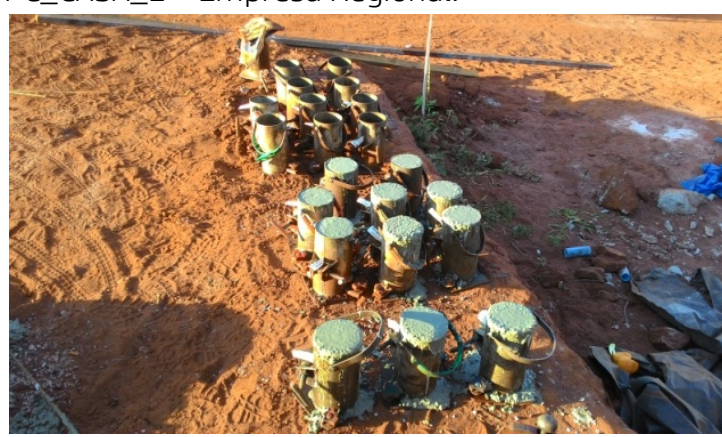

FONTE: Acervo da autora, 2016.

Imagem 69 - Preparação dos corpos de prova no PC_APTO_1 - Empresa Nacional.

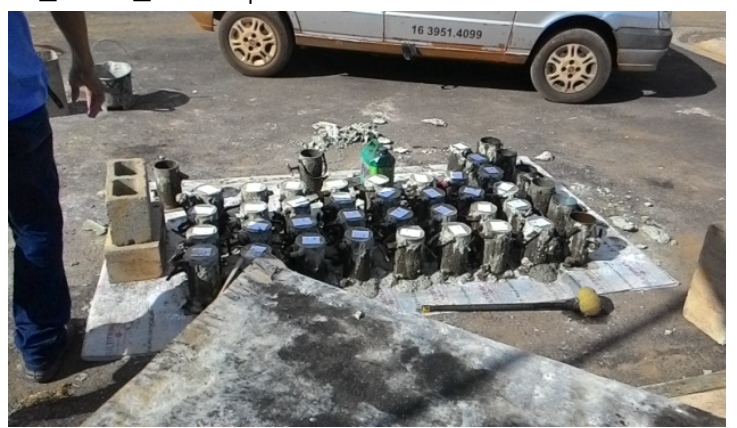

FONTE: Acervo da autora, 2016.
Imagem 68 - Corpos de prova PC_CASA_1 Empresa Regional.

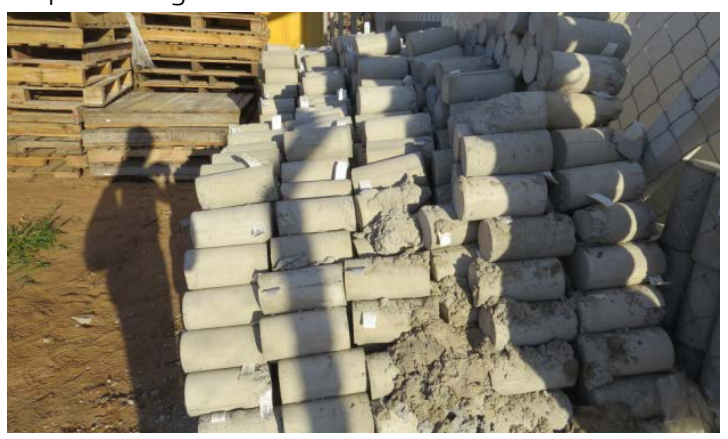

Imagem 70 - Preparação teste de cone no PC_APTO_1 - Empresa Nacional.

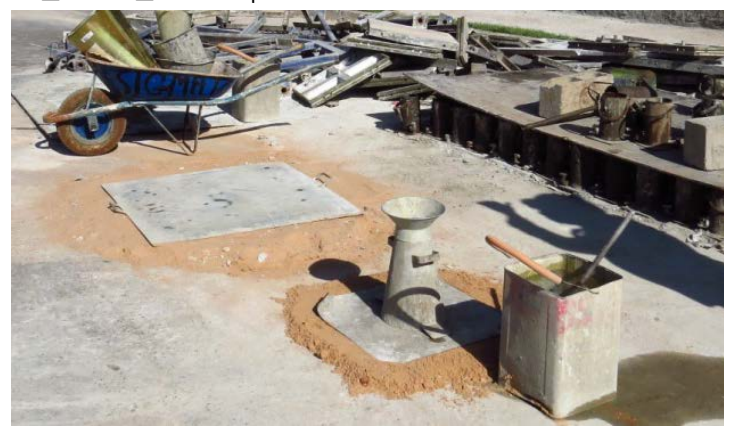

Em relação à fluidez, aferida através do teste de espalhamento, também existiam algumas variações. No empreendimento PC_APTO_2, era utilizado espalhamento entre 68 e $70 \mathrm{~cm}$ para concreto das paredes e $75 \mathrm{~cm}$ para o concreto das lajes. 0 concreto para a laje precisa ser um pouco mais trabalhável, mais fluido, para que seja possível nivelar corretamente a laje, uma vez que não era executado contrapiso nessa obra.

No PC_APTO_1 eram necessários $53 \mathrm{~m}^{3}$ de concreto para a concretagem de quatro apartamentos. Os testes de resistência eram realizados em laboratório dentro do próprio canteiro de obras. As paredes de concreto foram executadas com espessura de $10 \mathrm{~cm}$ e as lajes - que já eram concretadas juntamente com as paredes - com espessura de $12 \mathrm{~cm}$. A fornecedora de concreto - no caso, autoadensável - era a empresa Argasol. Não foi possível aferir se existia um segundo fornecedor. Na obra do PC_APTO_2, segundo o auxiliar na época havia apenas uma empresa fornecedora de concreto - a Concrepav. 
Uma estratégia utilizada pela Empresa Regional foi montar uma base de concreto dentro do próprio canteiro, no caso da obra do PC_CASA_1. A base da concreteira dentro do canteiro sem dúvidas evita os problemas relacionados ao fornecimento, que incluem atrasos na entrega ou mesmo a não entrega do produto. A demanda de concreto nesta obra na fase de concretagem das casas era em média de $120 \mathrm{~m}^{3}$ por dia. Se considerarmos 986 unidades que foram concretadas em média de oito casas por dia, podemos admitir que o processo de produção das estruturas de concreto levou aproximadamente 124 dias. Isto significa que no total a construtora utilizou por volta de $15.000 \mathrm{~m}^{3}$ de concreto nesta obra. Este volume justificou então a instalação da base da concreteira. Porém, esta era o maior empreendimento entre os estudados e o único que manteve uma base de fabricação de concreto dentro do canteiro.

Já no PC_CASA_2, duas concreteiras foram contratas para a obra: a Polimix e a Leão, entretanto, ao contrário do empreendimento PC_CASA_1, não foi montada base de concreto dentro do canteiro.

Nessas duas obras, para concretar cada unidade eram utilizados $15,5 \mathrm{~m}^{3}$ de concreto. Cada caminhão betoneira tem capacidade de $8 \mathrm{~m}^{3}$, deste modo, eram necessários dois caminhões para cada casa, e o que sobrava era exatamente o suficiente para concretar um oitão. A cada dia, portanto, eram concretadas as paredes e a laje de uma unidade e o oitão da casa concretada no dia anterior. Essa estratégia evitava a perda do concreto, mas exigia o planejamento e preparo das formas do oitão e das paredes e lajes da casa subsequente.

Uma questão importantíssima é que a concretagem da casa deve ser realizada de uma só vez, o que implica que os dois caminhões de concreto precisam chegar ao mesmo tempo na obra. Não é possível, por exemplo, lançar metade do concreto em um dia e a outra metade no dia seguinte, uma vez que o tempo de cura era muito curto, o que causaria uma trinca no meio da casa. 0 engenheiro do PC_CASA_2 deu o exemplo de uma situação em que um dos caminhões de concreto quebrou. Como eram necessários dois caminhões de concreto - $16 \mathrm{~m}^{3}$ - para concretar uma casa e um oitão, ele preferiu cancelar a entrega do outro caminhão também, uma vez que não seria possível fazer a concretagem da mesma unidade em dois momentos. 
O concreto é a matéria-prima base das paredes estruturais moldadas in-loco e, para este uso, as condições são bastante específicas: deve ser resistente e, ao mesmo tempo, muito trabalhável. Aí está um desafio das empresas construtoras, que é conseguir adequar o traço do concreto, para que ele chegue à resistência mínima estipulada pela norma e, além disso, seja fluido o suficiente para ser lançado verticalmente em paredes de cerca de 2,50 m de altura. Grande parte das patologias que podem surgir na execução das paredes de concreto está relacionada a erros na fabricação e no traço do concreto. Quando o concreto não tem boa plasticidade, por exemplo, a concretagem pode não ficar suficientemente homogênea, causando pequenos vazios nas paredes, as chamadas "bicheiras". Também é comum ocorrerem pequenas fissuras devido à retração. Uma alternativa frequentemente utilizada pelas construtoras é a utilização do concreto autoadensável, que tem maior fluidez e plasticidade, o que facilita o processo de lançamento e evita as patologias indesejadas.

Na obra do PC_APTO_1, enquanto aguardava o engenheiro em uma das visitas, pude acompanhar uma reclamação sobre o serviço do concreto. Segundo o engenheiro, a concreteira estava entregando o concreto com fck no limite de projeto e abaixo do requisitado pela construtora. 0 mínimo previsto em projeto seria fck $20 \mathrm{MPa}$ para as paredes, entretanto a construtora optava por utilizar o concreto com $25 \mathrm{MPa}$, para garantir a resistência. Os testes em laboratório estavam atingindo $21 \mathrm{MPa}$ aproximadamente. Por isso, o engenheiro estava cobrando da empresa fornecedora de concreto a melhora no produto. Uma questão ponderada pelo engenheiro é que a abatibilidade - ou o espalhamento - havia sido modificada para que o concreto ficasse mais trabalhável. Segundo o engenheiro, atualmente estavam utilizando entre 74 e $75 \mathrm{~cm}$, sendo que o previsto era de $65 \mathrm{~cm}$ (mais $5 \mathrm{~cm}$ de tolerância pra mais ou pra menos). 0 engenheiro pediu então para que a empresa verificasse se a mudança havia interferido na resistência do concreto, e se fosse o caso, para que a fornecedora adequasse o traço.

O concreto utilizado para a produção das paredes é sempre usinado e, portanto, as empresas fornecedoras devem atender aos requisitos da construtora. 0 caso citado explicita um problema recorrente: nem sempre as concreteiras entregam exatamente o que prometem. A prova disto é que na maioria das obras, as 
construtoras optam por empregar um concreto com resistência acima do estipulado em projeto porque não querem correr o risco de trabalhar no limite. Inclusive, o controle sobre a resistência do concreto é bastante rigoroso, todas as construtoras testavam as amostras dos concretos utilizados em laboratório instalado dentro do próprio canteiro.

Mas, para além da questão da qualidade do concreto, outro fator é bastante pertinente: o fornecimento. Dentro deste sistema, o concreto usinado é um material imprescindível e, de certo modo, as construtoras ficam extremamente vinculadas aos fornecedores. $\mathrm{O}$ atraso na entrega do concreto, por exemplo, pode comprometer todo o planejamento de produção da obra. Na obra do PC_APTO_2, existia apenas um fornecedor de concreto e a construtora estava buscando um segundo fornecedor com urgência. Isso porque trabalhar com apenas uma empresa torna a construtora refém deste fornecedor e o concreto é um insumo fundamental para o andamento da obra.

\section{Etapas de execução}

Evidentemente, a execução deste sistema exige alguns cuidados, a começar pelo nivelamento da fundação, antes do início da montagem das fôrmas. A produção das paredes de concreto é norteada pelas seguintes normas: 'ABNT NBR 6.118:2014 Projeto de Estruturas de Concreto - procedimento'; 'ABNT NBR 16.055:2012 Parede de Concreto Moldada no Local para a Construção de Edificações - Requisitos e Procedimentos'; e pela 'Diretriz da SiNAT n0001 - Revisão 02 - Diretriz para Avaliação Técnica de sistemas construtivos em paredes de concreto armado moldadas no local'.

Nas obras produzidas pela construtora Empresa Nacional, a execução das paredes de concreto é norteada pelo PES 45, que é divido em três partes: PES 45A - Parede de concreto; PES 45B - Parede de concreto: instalações hidrossanitárias e Esgoto; PES 45C - Parede de concreto: instalação de batente, porta e esquadria.

Nas quatro obras visitadas, apesar das diferenças nas tipologias, o processo de execução seguia estratégias muito próximas. Em todas as obras a fundação era o 
'radier' (no PC_APTO_1 foram executadas também estacas, além do radier), que era completamente nivelado. Finalizada a fundação, o próximo passo era a montagem das armaduras. Aqui existia uma diferença no método executivo dos empreendimentos de apartamentos e nos de casas térreas.

Nas obras de apartamentos, a montagem das armaduras geralmente era feita no chão, sobre um gabarito. Os trabalhadores seguiam a marcação, executavam a amarração dos ferros e depois outros trabalhadores instalavam os conduítes de elétrica (Imagem 71). Acabadas as etapas de montagem das armaduras e dos conduítes, o conjunto era içado - com o auxílio de um 'Munck' - até o local onde seriam concretadas suas respectivas paredes ${ }^{70}$ (Imagem 72). No caso das lajes, todo este processo de preparação da armadura era executado no respectivo pavimento, depois da montagem das fôrmas das paredes.

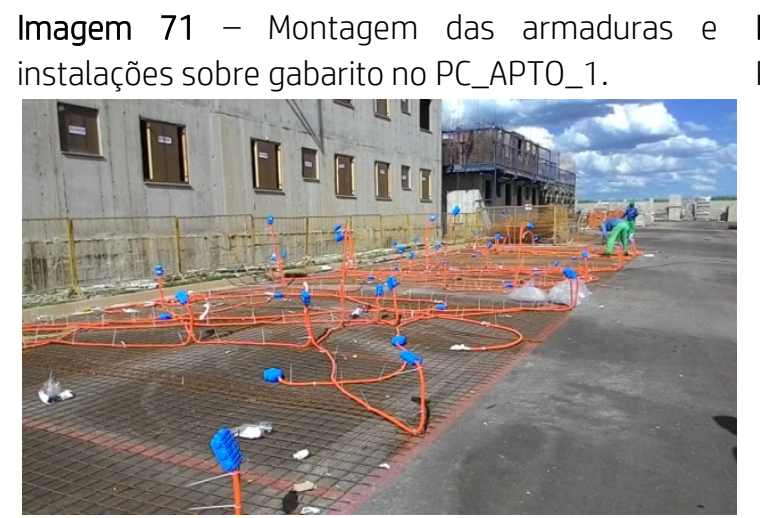

Imagem 72 - Içamento das armaduras das lajes no PC_APTO_1.

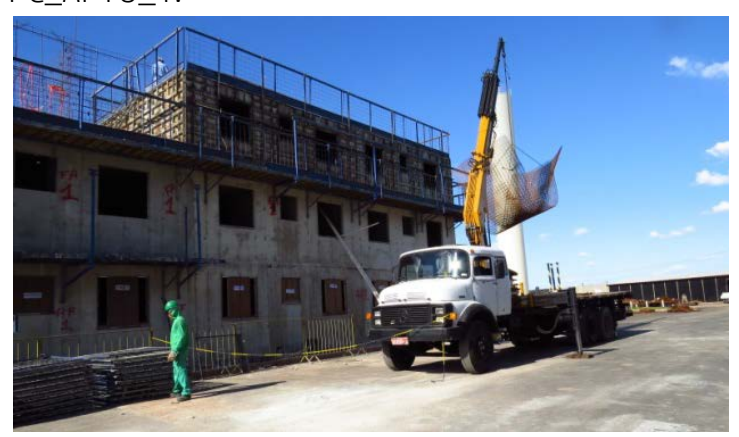

70 No caso do PC_APTO_1, os apartamentos dos blocos ficavam próximos à divisa do terreno não puderam ser executados deste modo porque o munck não tinha espaço para içar as armaduras. Sendo assim, toda a montagem das armaduras desses blocos teve que ser executada já nos edifícios, o que demanda maior trabalho e mais tempo. 
Imagem 73 - Posicionamento das armaduras no respectivo pavimento no PC_APTO_1.

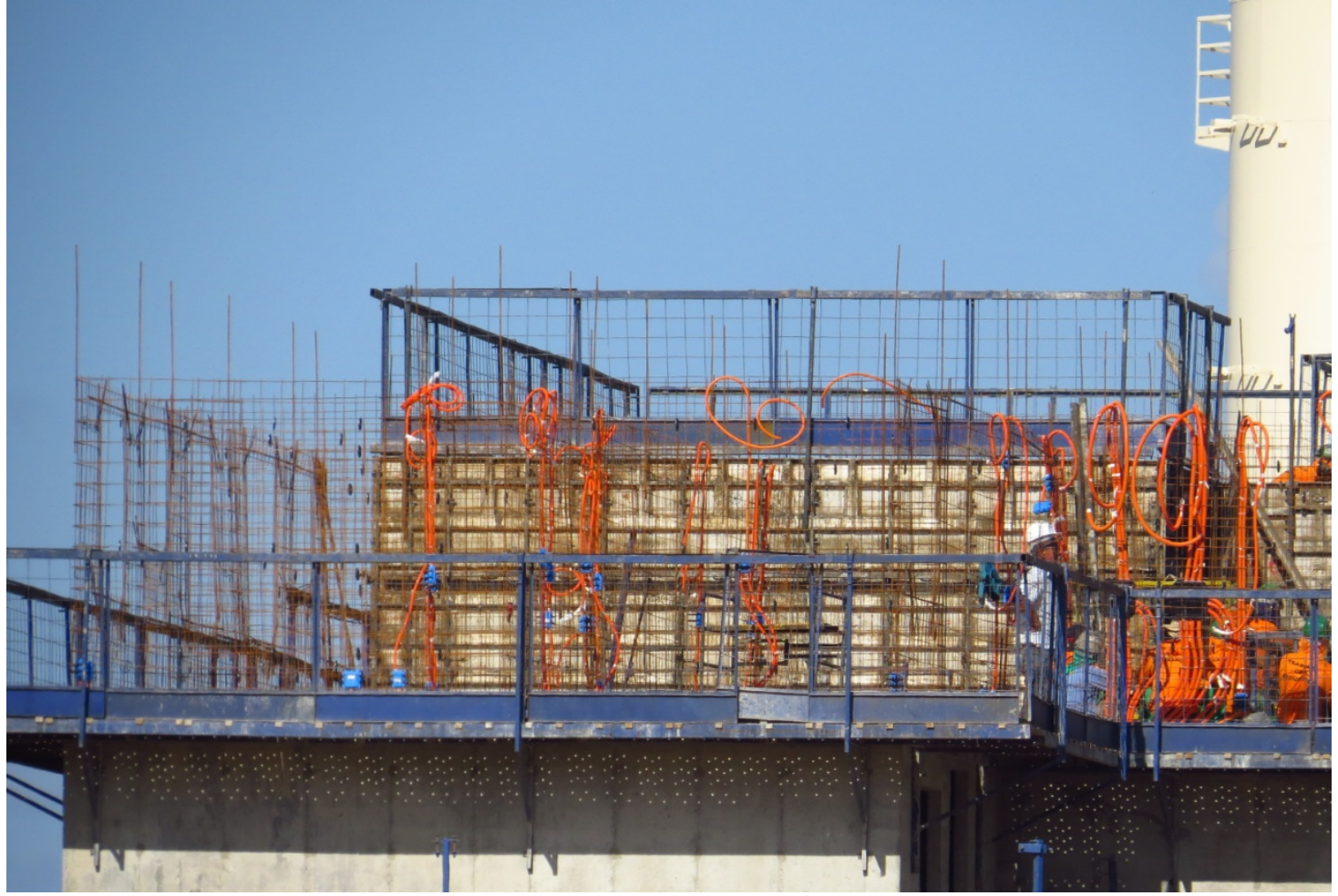

FONTE: Acervo da autora, 2017.

Já nas casas térreas essa estratégia não era necessária. As telas de armaduras eram posicionadas já no local final, juntamente com os conduítes e as caixas das instalações elétricas (Imagem 74). Toda a parte de hidráulica e elétrica, portanto, era instalada antes da concretagem. Em todas as obras eram utilizados 'kits' para as instalações, que chegavam já prontos ou eram pré-fabricados no canteiro em bases de pré-fabricação. Imagem 74 - Montagem das armaduras e
instalações no PC_CASA_1.

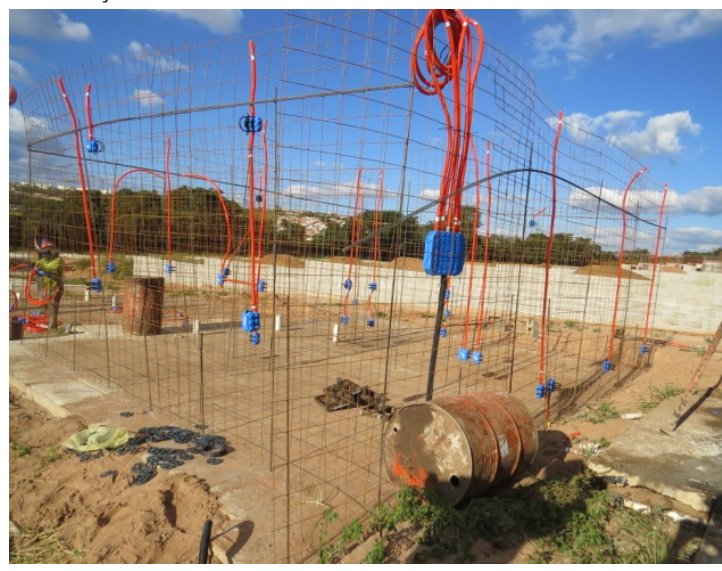

FONTE: Acervo da autora, 2015.
Imagem 75 - Montagem das armaduras e instalações no PC_CASA_2.

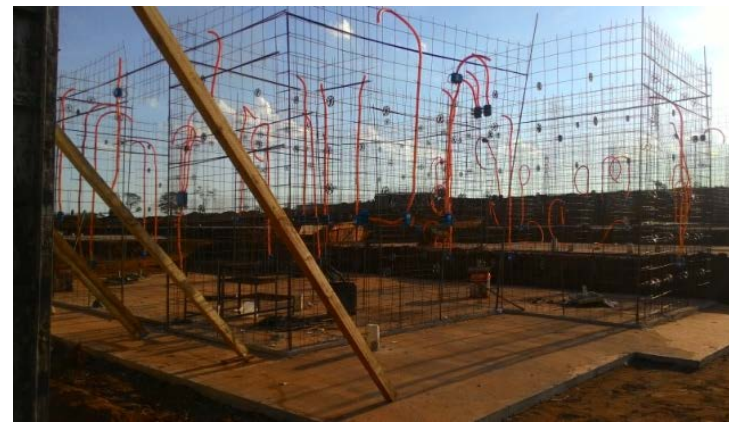

FONTE: Acervo da autora, 2016. 
Em seguida, eram montadas as fôrmas. Todas as peças eram retiradas do local da última concretagem e preparadas para a próxima utilização. 0 transporte das fôrmas era realizado manualmente, inclusive de um pavimento para o outro (no caso das obras de apartamentos). Em todas as montagens os trabalhadores aplicavam desmoldante nas faces das peças que ficariam em contato com o concreto. Esse processo facilita a atividade de desenforma, impedindo que as peças grudem no concreto já curado e, consequentemente estende a durabilidade das fôrmas.

A montagem era iniciada pelas faces internas das paredes. Nos empreendimentos de apartamentos, a sequência de produção seguia sempre a cada meio bloco. 0 primeiro pavimento de meio bloco era executado, em seguida se executava o primeiro pavimento do meio bloco ao lado, depois o segundo pavimento do primeiro meio bloco, em seguida o segundo pavimento do meio bloco ao lado e assim sucessivamente (Imagem 76). Desse modo, os trabalhadores posicionavam as armaduras de um pavimento, em seguida iriam desenformar o pavimento ao lado e remontar as formas no pavimento subsequente. Geralmente, a produção do sistema construtivo de um pavimento levava dois dias.

As peças eram posicionadas em seus respectivos locais e travadas com um pino, colocado com o auxílio de um martelo. Existiam também barras horizontais que auxiliavam neste travamento (Imagem 77). Depois que cada peça era posicionada e travada, os trabalhadores esticavam linhas para conferir o alinhamento das peças. Os eventuais ajustes eram feitos com golpes de marreta. As formas eram presas com elementos transversais chamados 'faquetas'. Esses elementos perpassam a parede de concreto e, após a desforma, devem ser retirados. Para facilitar este processo, as faquetas eram envolvidas com um cilindro de isopor que permitia a retirada das faquetas sem danificar as paredes já prontas. Depois que as placas das paredes estavam montadas, os trabalhadores instalavam também as peças das lajes, que ficavam apoiadas em escoras metálicas. 
Imagem 76 - Montagem das fôrmas nos blocos de apartamentos no PC_APTO_1.

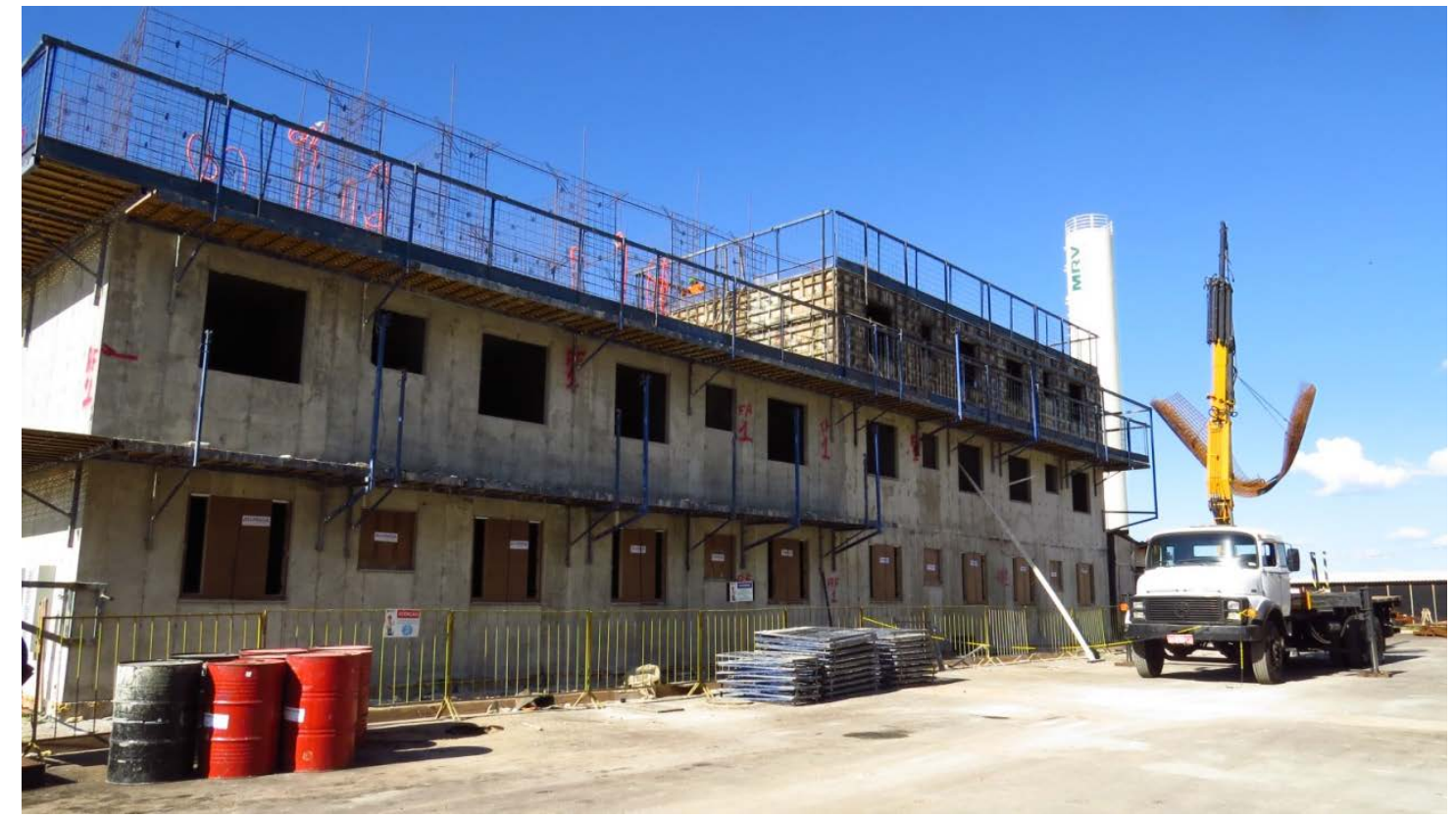

FONTE: Acervo da autora, 2016.

Imagem 77 - Montagem das fôrmas das casas do PC_CASA_1.

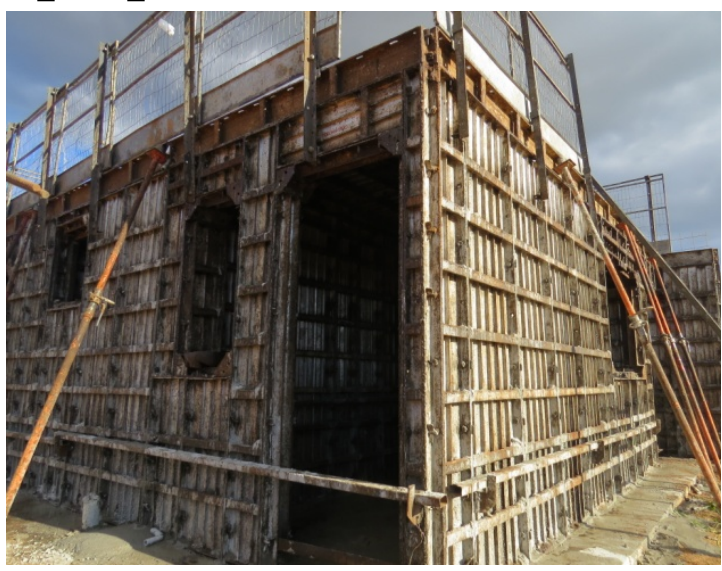

FONTE: Acervo da autora, 2015.

Imagem 79 - Montagem das fôrmas das casas do PC_CASA_2.

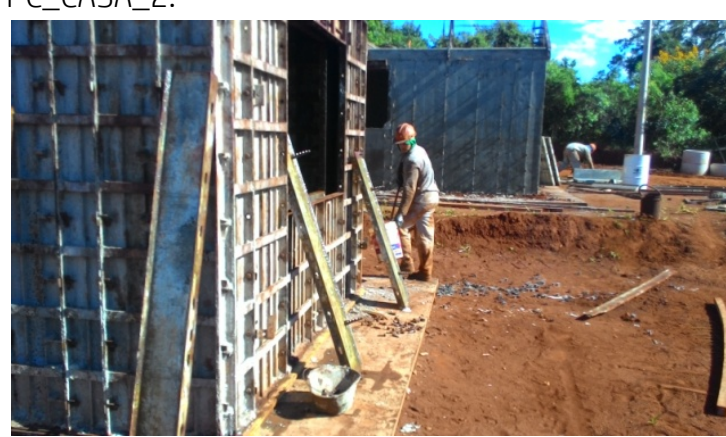

FONTE: Acervo da autora, 2016.
Imagem 78 - Montagem das fôrmas das casas do PC_CASA_1.

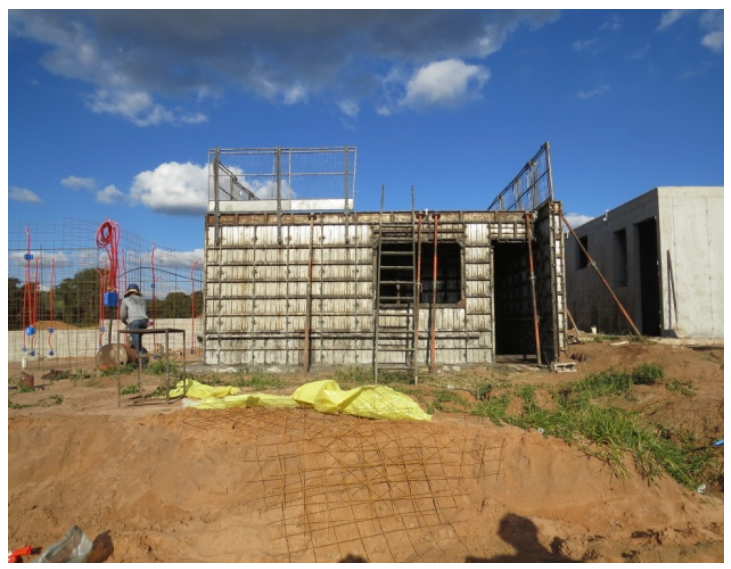

FONTE: Acervo da autora, 2015.

Imagem 80 - Montagem das fôrmas das casas do PC CASA 2.

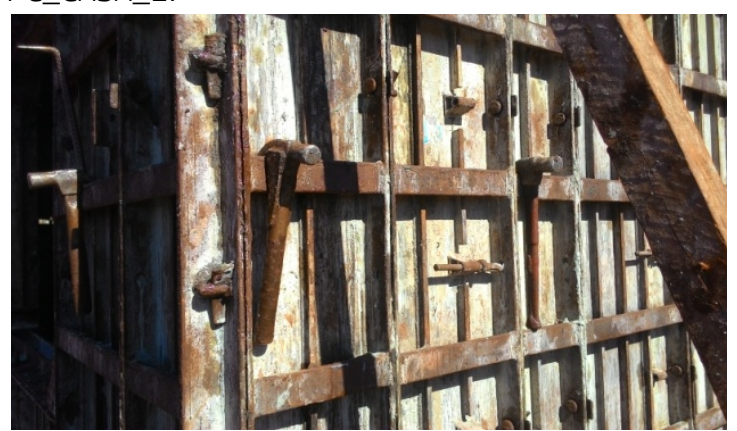

FONTE: Acervo da autora, 2016. 
Imagem 81 - Montagem das fôrmas das casas do PC_CASA_2.

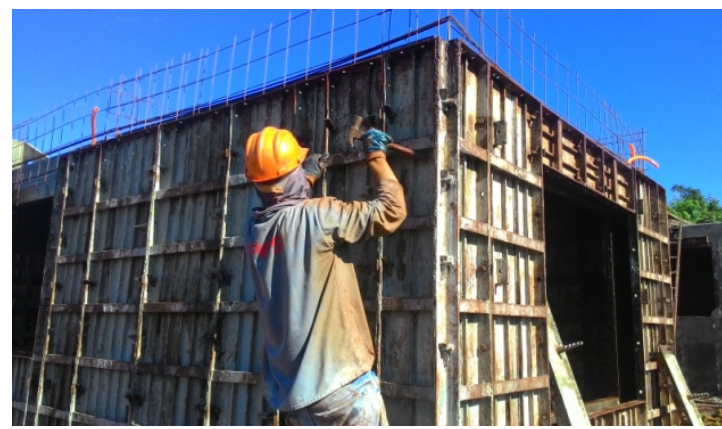

FONTE: Acervo da autora, 2016.
Imagem 82 - Montagem das fôrmas das casas do PC_CASA_2.

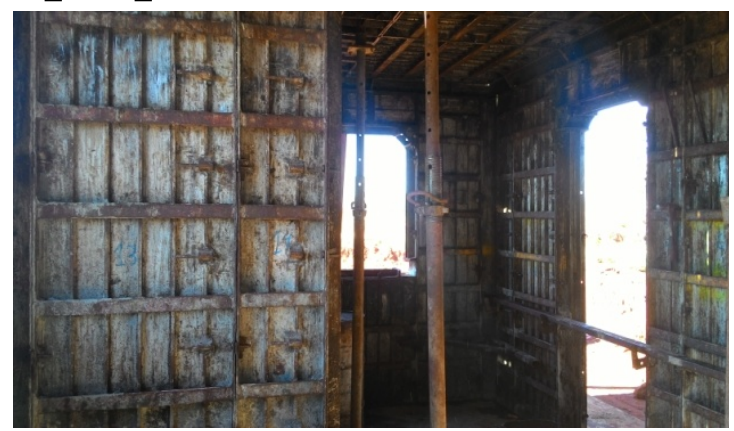

FONTE: Acervo da autora, 2016.

Imagem 83 - Montagem das fôrmas das casas do PC_CASA_1.

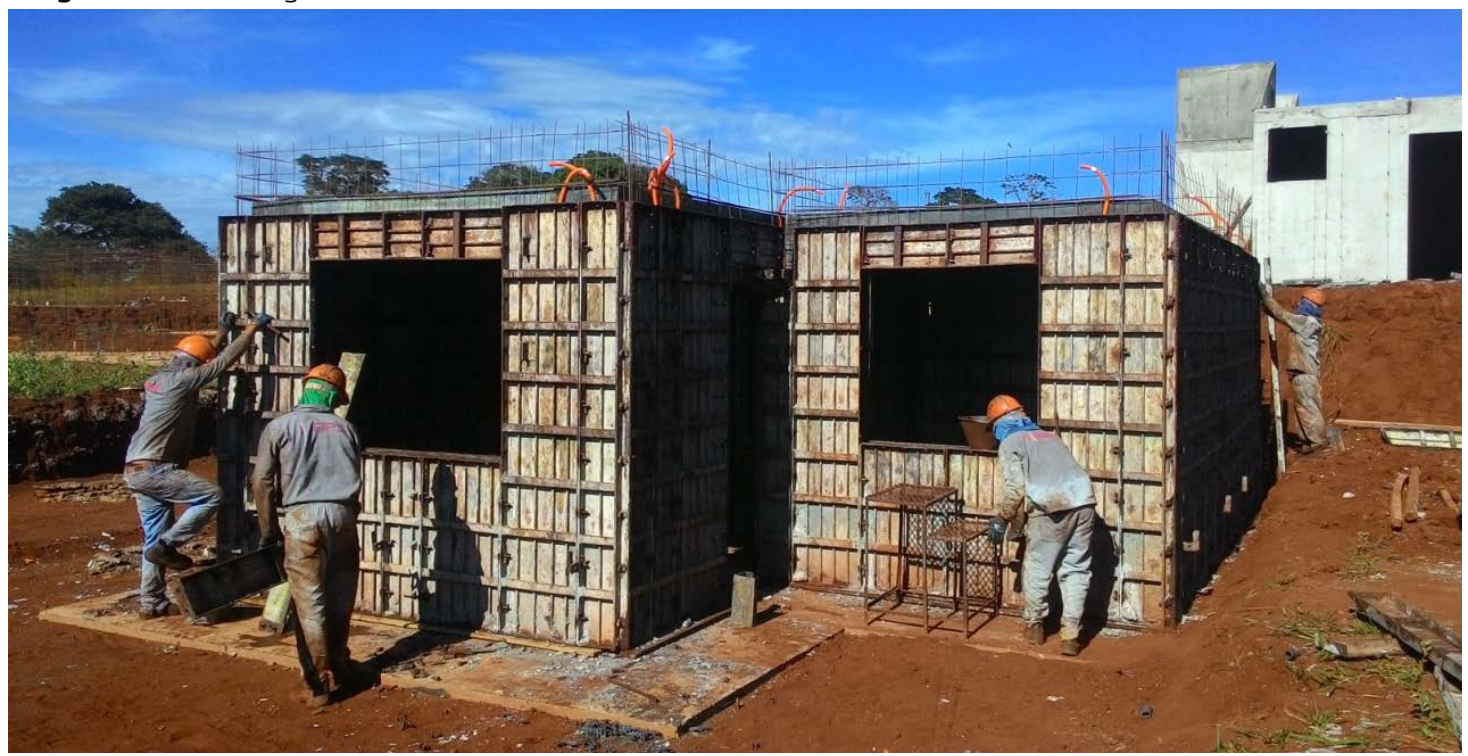

FONTE: Acervo da autora, 2016.

Tanto nas obras de apartamento quanto nas de casas térreas, não havia um sistema muito elaborado para a organização das fôrmas. As peças eram numeradas manualmente e os trabalhadores aprendiam a sequência de montagem empiricamente. Depois que as fôrmas estavam preparadas, era executada a concretagem com caminhões-bomba. Todo o concreto era usinado e autoadensável, dessa maneira, era feito o lançamento com bomba e não havia necessidade de vibrar o concreto (Imagem 84 e 85).

Depois da concretagem, era necessário esperar o tempo de cura do concreto - que variava ligeiramente de obra pra obra, como já comentamos - e aí executar a desenforma. Geralmente esse processo já podia ser realizado no dia subsequente à concretagem. As fôrmas eram retiradas, limpas e já remontadas na próxima 
edificação. As escoras internas eram mantidas por algum tempo, até que o concreto atingisse sua resistência máxima.

A etapa seguinte era a regularização das paredes e dos pisos. Basicamente era o processo de corrigir as imperfeições que apareciam após a desenforma e preparar as paredes para os revestimentos. No PC_CASA_1, era aplicada massa texturizada em todas as paredes e na laje. No PC_CASA_2 era utilizada apenas uma camada fina de massa antes da pintura, não era mais utilizada a textura.

No PC_APTO_1, depois da etapa de limpeza grossa e regularização das paredes e lajes, era passada uma massa para dar acabamento. Depois desta massa lisa, era executada uma textura nas paredes, mas não com uma massa de textura convencional. A textura era feita, segundo o encarregado, como uma massa tipo massa corrida, que é trabalhada para ficar com um aspecto rugoso. 0 encarregado não sabia o motivo da aplicação da textura.

Uma ponderação a ser feita é que esse sistema das paredes de concreto permitiria inclusive que não fosse aplicado nenhum tipo de revestimento, apenas um produto impermeabilizante ou uma resina, por exemplo. Tal solução inclusive traria economia às construtoras. Entretanto, provavelmente não teria boa aceitação por parte dos clientes e moradores. Dessa maneira, provavelmente por este motivo as empresas optavam por aplicar texturas. Nas áreas molhadas geralmente as paredes eram revestidas com azulejos.

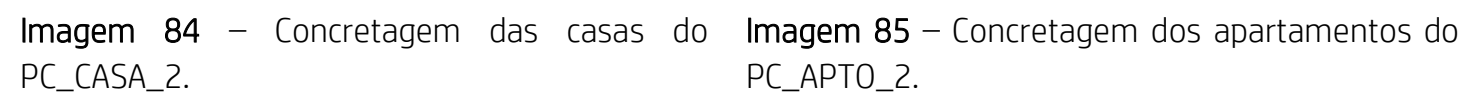

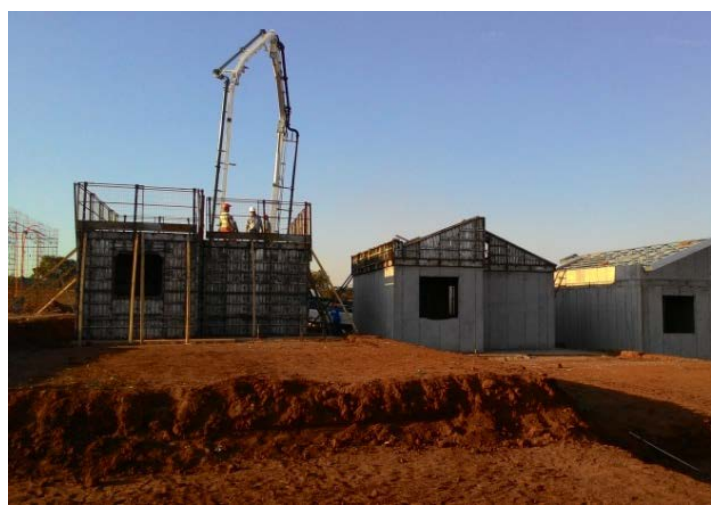

FONTE: Acervo da autora, 2016.

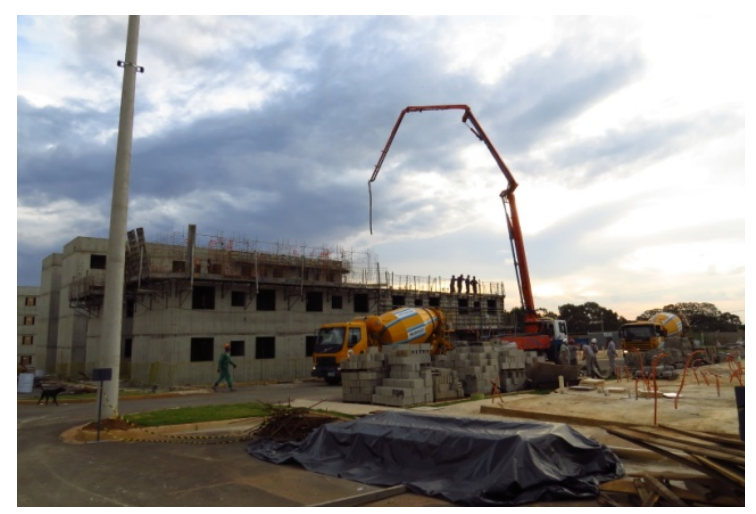

FONTE: Acervo da autora, 2017. 
Em relação ao número de trabalhadores necessários para execução da montagem das fôrmas e concretagem das paredes, evidentemente havia diferença entre as obras de apartamentos e de casas. Nas tipologias de edifícios, para cada jogo de forma - equivalente a um pavimento - eram necessários em torno de 30 funcionários que fazem montagem, desmontagem e concretagem; 5 operários para o serviço de armação e mais 2 funcionários para outros serviços gerais. Já nos outros dois empreendimentos de casas térreas cada casa era produzida por um grupo de oito trabalhadores.

Em relação à produtividade, a expectativa da Empresa Nacional era de realizar uma concretagem por dia, ou seja, construir um pavimento de um bloco por dia, entretanto essa meta dependia bastante dos trabalhadores estarem já familiarizados com a montagem das fôrmas. A Empresa Regional conseguia manter a produção de uma concretagem por dia para cada jogo de fôrma, que correspondia a uma casa.

No empreendimento PC_APTO_1, assim que o processo foi iniciado, 26 operários eram responsáveis pela execução das paredes de concreto com um jogo de formas. Esses trabalhadores eram subempreitados e não eram especializados neste tipo de obra, ainda estavam aprendendo a trabalhar com o sistema construtivo. As subempreiteiras 'Sérgio Lima' e 'J Construtora' eram responsáveis pelas paredes de concreto no início da obra. A 'J Construtora' também trabalhava com as paredes de concreto em outro canteiro da Nacional.

No decorrer da obra, entretanto, essas empresas foram substituídas por trabalhadores que vieram do Maranhão e já haviam trabalhado com as fôrmas de alumínio. As empresas inicialmente contratadas não estavam atingindo a produtividade que a Empresa Nacional desejava. Enquanto os novos trabalhadores produziam um pavimento com quatro apartamentos a cada dois dias, os subempreiteiros da região produziam esta mesma quantidade em uma semana. A equipe do Maranhão era formada por 30 trabalhadores que eram responsáveis por montar um jogo de fôrma que correspondia a um pavimento de quatro apartamentos.

Já na obra do PC_APTO_2 eram utilizados dois jogos de formas. 0 auxiliar afirmou que eles conseguiam 'virar' ao menos um jogo de forma por dia. Ou seja, todos os 
dias era realizada a concretagem de pelo menos quatro apartamentos. Nem sempre era possível ter esse aproveitamento para os dois jogos de formas devido ao tempo para desenforma. Em relação à mão de obra para a execução do sistema construtivo, a construtora teve certa dificuldade. Trouxeram então trabalhadores que já tinham tido contato com este sistema na própria construtora, mas em outras cidades, como Piracicaba e Campinas, uma vez que essa foi a primeira obra em São Carlos a ser executada com este sistema construtivo.

No caso do PC_CASA_2 oito operários eram responsáveis por cada jogo de fôrma. Dentro do processo de montagem das fôrmas, cada trabalhador é responsável por um setor da casa. Por exemplo, um dos operários sempre vai montar a parte da cozinha; outro executa a montagem das formas do banheiro; e assim por diante. $\mathrm{Ou}$ seja, cada um tem sua função pré-estabelecida. Existia também um "líder", que organizava e coordenava a montagem.

Na obra do PC_APTO_1, estava sendo executada a 'laje zero', que é um tipo de laje que dispensa o contra piso ${ }^{71}$. A concretagem dessas lajes é feita de modo que a superfície já fique regular e assim não há a necessidade de acrescentar o contra piso. O encarregado afirmou, entretanto, que nem sempre eles conseguiam executar a laje zero, porque às vezes a concretagem da laje não fica regular o suficiente e nesse caso, mesmo não estando previsto, era preciso fazer o contrapiso para regularizar a laje. Ele disse ainda que nos últimos blocos executados isto não ocorreu, mas que no início da obra algumas concretagens foram feitas à noite, e que esse fator dificultava a boa execução.

A laje zero é uma clara iniciativa da construtora de racionalizar o processo produtivo, uma vez que esta técnica permite a elimina a necessidade do contrapiso. Entretanto, no caso do PC_APTO_1 algumas falhas de execução acabaram gerando o retrabalho e provavelmente até um atraso no andamento da obra. É possível admitir, portanto, para que alguns processos racionalizados sejam realmente

\footnotetext{
${ }^{71}$ Em relação à laje convencional, com a laje zero é possível gerar uma economia de aproximadamente $4 \mathrm{~cm}$ da argamassa do contrapiso. A grande desvantagem, entretanto, é que a supressão do contrapiso pode gerar complicações em relação à aderência de revestimentos e também ao desempenho acústico da laje.
} 
vantajosos, é necessário que se tenha o domínio sobre o processo executivo, caso contrário esta iniciativa pode representar desvantagem e prejuízo.

As fôrmas utilizadas na obra do PC_APTO_1 incluíam o chamado "jacaré", que se trata do apoio para os degraus da escada (Imagem 86). Apesar de parecer uma questão secundária, este detalhe construtivo executado em conjunto à estrutura da edificação poupa o trabalho de executar o "jacaré” depois da estrutura pronta.

No empreendimento PC_CASA_2 pude subir sobre uma casa que estava com as fôrmas montadas, já pronta para ser concretada. Foi possível observar, deste modo, a tela de armadura da laje, assim como as instalações elétricas que já estavam posicionadas. A armadura da laje estava posicionada sobre a fôrma, com auxílio de espaçadores. Todos os conduítes das instalações elétricas estavam amarrados sobre a armadura (Imagem 87). Esses conduítes desciam por dentro das fôrmas das paredes, e as caixinhas dos pontos de elétrica também estavam já posicionadas.

Em algumas casas, foi possível observar um pequeno problema depois da retirada das fôrmas. Estavam aparecendo alguns defeitos e imperfeições nas paredes, que teriam que ser resolvidos posteriormente com durante a regularização das paredes. Em algumas situações, durante a desenforma uma parte da parede se desprendeu, deixando à mostra parte da armadura (Imagem 88 e 89).

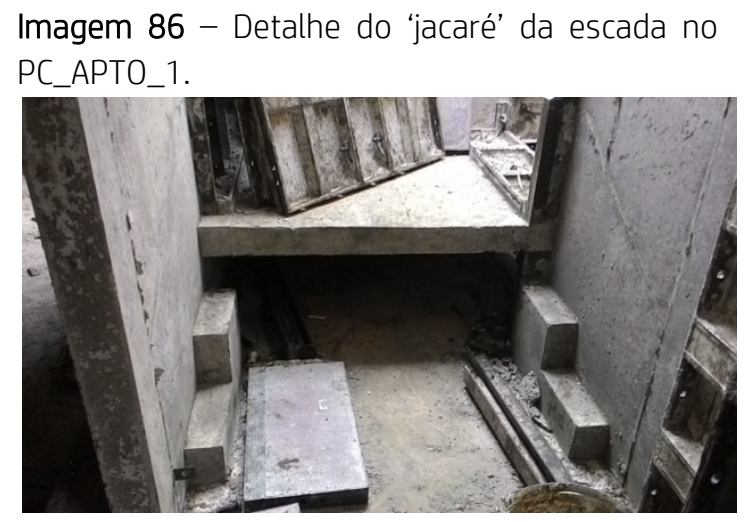

FONTE: Acervo da autora, 2016.
Imagem 87 - Armadura e conduítes da laje no PC_CASA_2.

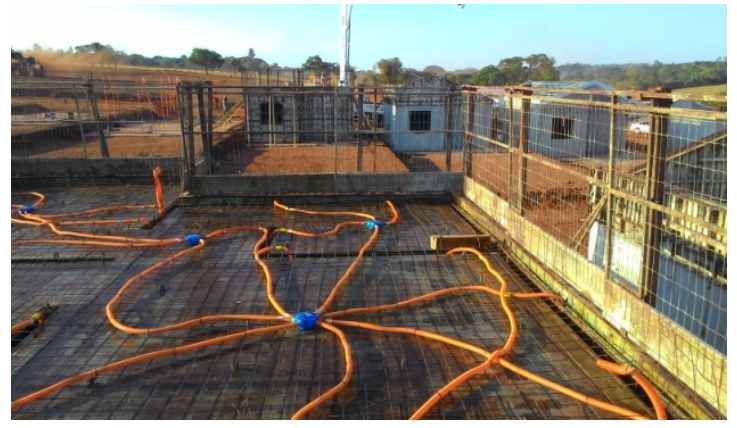

FONTE: Acervo da autora, 2016. 
Imagem 88 - Defeito gerado no momento da desenforma no PC_CASA_2.

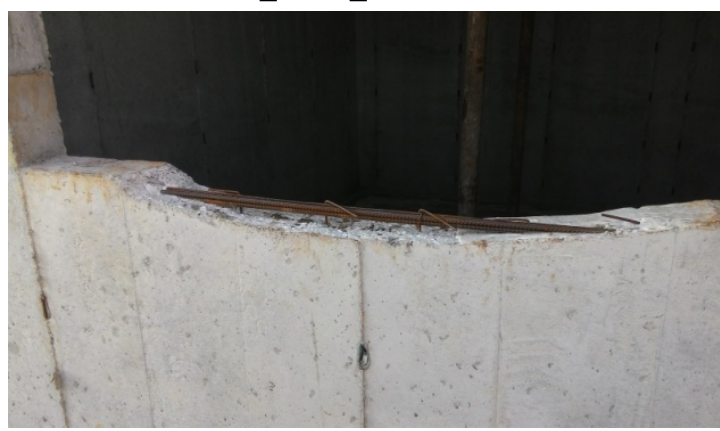

FONTE: Acervo da autora, 2016.
Imagem 89 - Defeito gerado no momento da desenforma no PC_CASA_2.

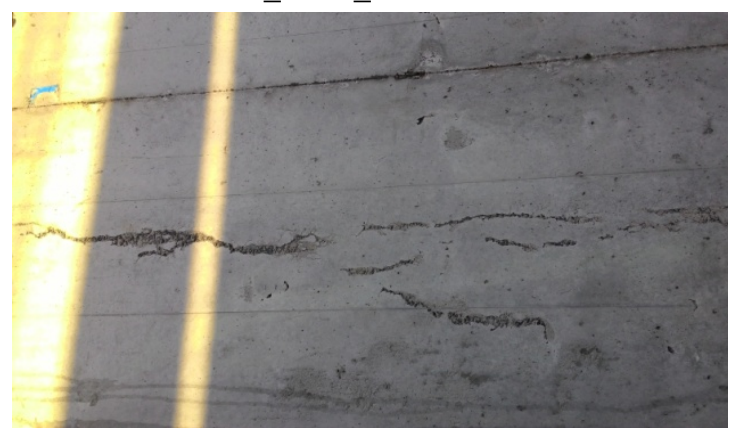

FONTE: Acervo da autora, 2016.

A observação da execução das paredes de concreto nos quatro empreendimentos mostrou que as construtoras conseguem atingir um nível bastante satisfatório de produtividade. 0 processo é racionalizado, sendo que os diversos sistemas paredes, lajes, instalações elétricas e hidráulicas, aberturas - são compatibilizados entre si, evitando a sobreposição de serviços e os retrabalhos. Entretanto, a formação da mão de obra é um obstáculo a ser vencido. 0 trabalhador continua tendo papel fundamental no processo construtivo, assim como acontece com a alvenaria estrutural e, por isso, o domínio da execução é essencial para se atingir bons resultados. Foi perceptível também que as construtoras ainda enfrentam falhas na execução, como a adequação do traço do concreto e as imperfeições nas paredes depois da desenforma.

Em uma conversa com engenheiro do PC_CASA_1, questionei sobre a vantagem do sistema construtivo de parede de concreto em relação à alvenaria estrutural. Segundo ele, apesar do custo ser parecido, a alvenaria estrutural apresenta um processo muito mais trabalhoso e bem mais sujo. Já na parede de concreto, é necessário apenas furar o radier, colocar a armadura e a forma e concretar. Além disso, a alvenaria leva mais tempo para a execução, devido às suas próprias etapas de execução. Não se pode fazer a elevação da alvenaria de uma casa inteira em apenas um dia. Já as paredes de concreto permitem a execução de uma casa por dia e por forma. "Alvenaria é bloco, é alvenaria, argamassa...processo trabalhoso, 
sujeira, resto de massa...", já o sistema construtivo de paredes de concreto "é uma indústria, uma linha de produção" 72 . 


\section{CAPÍTULO 5}

\section{As perspectivas de inovação da Empresa Nacional}

As duas últimas décadas foram marcadas por dois momentos peculiares no que diz respeito à situação econômica do país e consequentemente ao setor da construção civil. Um primeiro momento, desde meados dos anos 2000, se caracterizou como um período de crescimento e de desenvolvimento econômico no Brasil, sendo que as atividades da construção estavam aquecidas e com perspectivas bastante otimistas. Por volta de 2014, entretanto, esse cenário se alterou tendo em vista a crise política e econômica do país que impactou todos os setores produtivos e, de forma particular, o setor da construção. Como ficaria então a produção habitacional voltada ao segmento econômico? As construtoras continuariam com o mesmo ritmo produtivo?

A Empresa Nacional com sua produção voltada ao segmento econômico tem relação estreita com os programas públicos de financiamento habitacional, especialmente com o PMCMV. A crise, por sua vez, impactou diretamente essa provisão de créditos, e o programa foi progressivamente sofrendo cortes, tendo suas metas reduzidas e, no momento da redação desta dissertação, no início de 2018, está paralisado. Quais foram então as perspectivas da Nacional frente a esse contexto já não tão otimista? Sua produção em escala seria mantida, assim como seu projeto de expansão geográfica? Ou seu escopo de atuação seria reduzido? A empresa investiria em inovações tecnológicas e novas estratégias de gestão e organização?

Em CBIC (2016) logo na introdução, analisa-se justamente o contexto brasileiro em relação ao período de transição entre a etapa de maior desenvolvimento e a recente crise. Nesse cenário, no que se refere às atividades da construção, foi identificado 
um aumento no custo da mão de obra, segundo a CBIC (2016), devido ao modo desordenado de crescimento do mercado imobiliário. Essa situação seria um incentivo para que as empresas investissem em tecnologia a fim de se reduzir o volume de trabalhadores e o custo das obras. As inovações aparecem, portanto, como uma alternativa para a redução da utilização de mão de obra, para o aumento da produtividade e para a redução do custo de produção.

Castro (1999) afirma que os momentos de crise obrigam as empresas a analisarem seus processos produtivos, uma vez que a competitividade alcança novos patamares e a racionalização dos processos através de sistemas inovadores pode ser um diferencial em meio a uma grande concorrência. Em diversos momentos a ICCSE buscou estratégias de racionalização para superar momentos de crise do setor, como já debatemos no capítulo 1.

O desempenho da Empresa Nacional nos últimos anos, apesar da crise, foi bastante positivo, conforme apontado na introdução desta dissertação e o processo de racionalização da produção adotado pela construtora teve papel importante nesse sentido. A pesquisa de campo nos canteiros de obras da Nacional revelou diversas estratégias voltadas à otimização da produção. Atualmente, é possível observar que as inovações tecnológicas aparecem como uma questão central no projeto de desenvolvimento da empresa.

Além das estratégias de racionalização, a Nacional também buscou equilibrar seus índices de lançamentos e vendas de imóveis durante o período mais agudo da crise. Conforme apresentado na introdução desta dissertação, até o ano de 2011 a construtora produziu um excedente de unidades. A partir de 2012 as vendas superaram os lançamentos, indicando que foi um momento de redução de estoque. Somente em 2017 os números de lançamentos dos imóveis se aproximaram novamente dos números de vendas.

A busca por novas tecnologias que possam ser utilizadas para ampliar as formas de controle sobre o trabalho e sobre os materiais, bem como para aumentar a produtividade e reduzir custos, já se trata de uma realidade na ICCSE. Não mais está na pauta a industrialização plena da produção. As ações das empresas da construção se concentram muito mais na perspectiva da racionalização e a inovação tecnológica se coloca como uma estratégia importante dentro desse processo. 


\subsection{A inovação na ICCSE}

A implementação de inovações tecnológicas dentro do processo produtivo das empresas da ICCSE vem se tornando uma importante estratégia de desenvolvimento. 0 termo 'inovação', entretanto, carrega certa ambiguidade, uma vez que não se trata apenas de uma nova ideia - ou uma invenção ${ }^{73}$. Efetivamente, uma solução inovadora precisa ser incorporada pelo mercado como uma tecnologia que, além de nova, traga alguma melhoria ao processo produtivo ou ao produto final. Nesse sentido, Sabbatini (1989) apresenta a seguinte conceituação:

Um novo produto, método, processo ou sistema construtivo introduzido no mercado, constitui-se em uma INOVAÇÃO TECNOLÓGICA na construção de edifícios quando incorpora uma nova ideia e representa um sensivel avanço na tecnologia existente em termos de: desempenho, qualidade ou custo do edifício, ou de uma sua parte (SABBATINI, 1989, p. 51).

Uma conceituação similar foi utilizada recentemente em CBIC $(2016,17)$ :

[...] inovação seria o uso atual de uma mudança não trivial e melhoria no processo, produto, ou sistema que é novo para o desenvolvimento da mudança na instituição (FREEMAN, 1989 apud SLAUGHTER, 1998). No entanto, não teria que ser nova para as instituições existentes, somente para a que está adotando-a (SLAUGHTER, 1998; TIGRE, 2006).

O termo inovação pode se referir a um produto ou a um processo, mas não necessariamente uma inovação de produto será também uma inovação de processo, e vice-versa. Uma primeira ponderação, portanto, é que determinada solução pode ser considerada inovadora ou não a depender do referencial. De acordo com Amorim $(1996,266)$ :

A primeira dificuldade para abordar as inovações, na Construção, é caracterizar ou identificar o que é um "produto novo" e o que é uma inovação de processo. Cada produto é formalmente diferenciado e poderia ser chamado de "novo", porém ele é executado pelo mesmo processo, com os mesmos insumos e materiais, logo é "velho". Mesmo a introdução de novos insumos, tais como novas esquadrias e revestimentos, nem sempre

\footnotetext{
73 De acordo com Sabbatini (1989), "Inovação não é invenção. A invenção é um processo de descobrir ou criar uma nova ideia, enquanto que inovação tecnológica tem sido definida como "um processo que compreende a criação, o desenvolvimento, o uso e a difusão de um novo produto ou processo'. Com este sentido, pode ser entendida como a operacionalização de uma nova tecnologia" (SABBATINI, 1989, p.49).
} 
As inovações na construção civil podem ocorrer, portanto, em diversos níveis. Amorim (1996) identifica três principais níveis: nos produtos da construção; nos produtos para a construção; e na organização da produção. 0 primeiro nível, que se refere aos produtos da construção incorpora as inovações que são perceptíveis ao usuário final, ou seja, efetivamente se trata da edificação pensada de modo inovador, como por exemplo, os edifícios inteligentes. Já o segundo nível traz as inovações nos produtos para a construção, sejam eles insumos ou equipamentos, e que não alteram o produto final, mas sim o processo produtivo. Pode ser um novo material ou um novo equipamento empregado para determinada atividade. Finalmente, o terceiro nível refere-se às inovações na organização da produção que pode ser um novo modelo de gerência, por exemplo. 0 autor frisa que esses níveis de inovação na construção podem às vezes se sobrepor, sendo que uma inovação de produto para a construção pode impactar o processo produtivo; ou um produto inovador para a construção, apesar de não representar um diferencial para o leigo, pode impactar no custo final da edificação, e consequentemente no mercado. Ou seja, a implementação de inovações tem um efeito amplo em todo o processo produtivo dentro da construção civil (AMORIM, 1996).

0 autor destaca ainda que cada nível de inovação impacta um determinado aspecto dentro do processo produtivo. A inovação do produto "edificação" está mais relacionada à questão da competitividade, uma vez que interfere nos prazos e na variedade do produto final. A inovação do segundo nível, ou seja, de materiais e equipamentos para a construção impacta principalmente a produtividade, já que influencia no processo produtivo e permite ampliar e intensificar o trabalho. Finalmente, a inovação organizacional tem maior relevância na questão da flexibilidade, uma vez que novos modelos de organização ampliam a capacidade de adaptação da empresa ao mercado. Os tipos de inovações implementadas por determinada empresa podem demonstrar suas características e objetivos (AMORIM, 1996).

No Brasil, as construtoras preferem reduzir a variedade de tecnologias empregadas nas obras, priorizando um "padrão de obras" baseado em um universo restrito de soluções. Os ganhos de produtividade na ICCSE estão mais vinculados à 
intensificação do trabalho e por isso a questão organizacional costuma ter maior destaque para as empresas construtoras. Amorim (1996) identificou inclusive que as empresas direcionavam os maiores investimentos para estratégias de gerência e controle, frisando a questão da qualidade (AMORIM, 1996).

Desse modo, os avanços no desenvolvimento dos produtos da construção e para a construção acabavam nas mãos dos fornecedores. Como grande parte dessa cadeia era formada por multinacionais com produtos já consolidados no mercado (como tintas e cimento), o desenvolvimento de inovações podia ser visto como uma estratégia competitiva. Trata-se de um diferencial em meio a empresas que oferecem produtos similares (AMORIM, 1996).

Amorim (1996) frisa o papel dos fornecedores de materiais e equipamentos no processo de desenvolvimento de inovações na construção civil. Sua hipótese é que os fornecedores deveriam ter uma relação mais estreita com organizações de pesquisas e assim alcançarem maior capacidade de desenvolvimento de inovações para a construção civil. A cargo das construtoras ficaria mais especificamente a 'responsabilidade' pela implementação das inovações organizacionais.

Nossa ênfase, por outro lado, recai sobre as empresas construtoras e suas estratégias para o desenvolvimento e aplicação de novas tecnologias nos processos produtivos. Uma questão central é compreender até que ponto as construtoras participam do processo de desenvolvimento ou implementação de inovações tecnológicas.

Através do acesso a uma plataforma online - a Plataforma iTec - na qual diversas empresas buscam soluções tecnológicas, foi possível tomar conhecimento de algumas iniciativas da Empresa Nacional no que diz respeito ao desenvolvimento de inovações tecnológicas. Uma primeira observação sobre a participação da Nacional na Plataforma iTec é que a construtora está criando um vínculo direto com organizações desenvolvedoras de soluções tecnológicas, sem intermediação dos fornecedores de materiais e equipamentos.

A empresa buscava, dentro dessa plataforma, estratégias de racionalização da produção que pudessem ser aplicadas em larga escala e de modo padronizado em suas obras. A participação da Empresa Nacional na Plataforma iTec aconteceu no ano de 2016, justamente o período em que a crise econômica do país se agravou. 
Muito provavelmente, a crise impulsionou a empresa a aprimorar as iniciativas de controle e gestão e a incorporar novas tecnologias em seu processo produtivo, numa clara perspectiva de racionalização.

\subsection{Plataforma iTec}

A Plataforma iTec é uma plataforma aberta ${ }^{74}$ e online que promove o encontro entre empresas que apresentam uma demanda por solução tecnológica e organizações que procuram, por sua vez, resolvê-las. Essa plataforma faz parte do Programa iTec, uma iniciativa da Associação Nacional de Pesquisa e Desenvolvimento das Empresas Inovadoras (ANPEI) e do Ministério da Ciência Tecnologia e Inovação (MCTI). Entre as ações do Programa iTec estão: a Plataforma iTec - Desafios e Soluções Tecnológicas; Encontros Presenciais iTec - Encontros de Negócios em Inovação e Tecnologia; suporte às empresas; e Road Show (Workshops).

Atualmente, as áreas de interesse da plataforma são: nanotecnologia; biotecnologia; tecnologia da informação e comunicação (TIC); fármacos e complexo industrial da saúde (CIS); energia; fomento da economia verde; aeroespacial e complexo industrial da defesa (CID); mineração. Participam dessa plataforma atualmente 16 grandes empresas de diversos ramos industriais, como mineração e metalurgia, aeronáutico, alimentício, farmacêutico e químico, além de empresas especializadas em desenvolvimento tecnológico. É importante ressaltar que a Empresa Nacional era a única participante no ramo da construção e da incorporação. A atividade mais intensa na Plataforma iTec ocorreu em 2016, quando foram promovidos diversos encontros presenciais entre as empresas e organizações.

O objetivo dessa plataforma é o desenvolvimento da inovação aberta com transferência de tecnologia entre as instituições de pesquisa e os setores empresariais, com a geração de novos negócios. Enquanto a inovação fechada é

\footnotetext{
${ }^{74}$ Através de um cadastro na plataforma é possível acessar os desafios propostos pelas empresas. Só é possivel efetuar o cadastro de empresas ou instituições de pesquisa, uma vez que a plataforma não é voltada à pessoa física.
} 
resultado do trabalho desenvolvido obrigatoriamente por uma equipe interna de uma empresa, em todas as suas etapas, a inovação aberta justamente pressupõe o desenvolvimento tecnológico através de um trabalho colaborativo. É o modelo de inovação aberta que a Plataforma iTec propõe, uma vez que se trata exatamente de um ambiente colaborativo no qual o desenvolvimento de soluções tecnológicas se baseia na junção de ideias internas e externas de uma empresa. Nas orientações fornecidas pelo iTec, destaca-se que a inovação aberta exige menor investimento em pesquisas e estrutura ${ }^{75}$.

O formato dessa interação entre as empresas que buscam inovações e as organizações que apresentam soluções se dá através de propostas de 'desafios'. As empresas identificam determinada situação problema, contextualizam tal situação e a partir daí lançam um desafio. Existem alguns critérios e recomendações, bem como a determinação de um cronograma. As organizações ${ }^{76}$ interessadas, por sua vez, podem propor soluções para a situação problema através da plataforma online. Trata-se de um processo bastante direcionado, uma vez que as empresas que buscam soluções estruturam cuidadosamente suas propostas de desafios, especificando suas necessidades. Dessa maneira, as organizações colaboradoras podem oferecer soluções mais assertivas.

A plataforma iTec é, portanto, um modo de operacionalização das inovações tecnológicas da Empresa Nacional. Através desse ambiente digital, a construtora encontrou um modo de fomentar o desenvolvimento de novas soluções que pudessem ser aplicadas especificamente em seu processo produtivo.

A Empresa Nacional lançou desafios na Plataforma iTec na busca por soluções que pudessem ser aplicadas em suas obras. As propostas de desafios evidenciam alguns pontos críticos de seu aspecto produtivo, tanto em relação à gestão e à organização quanto em relação às soluções técnicas para as obras. 0 primeiro desafio proposto

\footnotetext{
75 Guia Prático do iTec (s.d). Utiliza a conceituação proposta por Henry Chesbrough em seu livro "Open Innovation" (2003).

76 Podem ser empresas de porte pequeno, médio e grande; empresas incubadas; startups; parques tecnológicos; instituições científicas e tecnológicas (ICTs); entidades como universidades e institutos de pesquisa públicos ou privados.
} 
é ampliar o controle sobre os trabalhadores através de dispositivos capazes de mapear e fiscalizar minuciosamente suas ações. O segundo é o controle, não mais dos operários, mas das peças das fôrmas de alumínio utilizadas nas obras, também se valendo da tecnologia da informação. E o terceiro desafio da empresa busca a substituição dos revestimentos cerâmicos em suas obras por um material que seja de aplicação mais prática.

\subsection{Os desafios propostos pela Empresa Nacional}

Os três desafios apresentam particularidades no que diz respeito aos objetivos pretendidos, aos meios utilizados e também ao tipo de inovação desejada. Cada proposta desenvolvida pela Empresa Nacional é aqui apresentada na íntegra, como consta na plataforma.

\section{DESAFIO 1}

Quadro 6 - Texto integral apresentado pela Empresa Nacional.

Equipamento de rastreamento e monitoramento eletrônico de colaboradores para a melhoria da gestão e otimização da equipe e dos recursos

\section{DESCRIÇÃO}

Desenvolvimento de um sistema de rastreamento geolocalizado e monitoramento eletrônico dos colaboradores na execução de serviços externos e internos, para melhoria da gestão e otimização da equipe e dos recursos. A partir de uma integração com os demais sistemas da empresa, procura-se desenvolver um programa que permita checar a localização planejada nas Ordens de Serviço e comparar com o que acontece em campo, por meio da localização do colaborador. 0 sistema será utilizado para auxiliar a análise de produtividade das equipes, acompanhar a localização dos funcionários no canteiro de obras e em serviços externos, em tempo real, comparando com a localização do serviço planejado. Além disso, espera-se que ele seja capaz de mensurar os deslocamentos de modo a melhorar o layout dos canteiros e otimizar as rotas nas visitas externas. 0 monitoramento por meio de chip no crachá ou no capacete do funcionário e o uso de tecnologia wearable estão entre as opções avaliadas.

ÁREAS DE INTERESSE OU SUBÁREAS

Tecnologia da Informação e Comunicação (TIC) - Sensores Analógicos.

\section{OPORTUNIDADE}

Preferência para contratação de joint venture, licenciamento de patente/tecnologia, projeto de desenvolvimento em parceria ou acordo de fornecimento.

\section{FASES DE DESENVOLVIMENTO ESPERADAS}

Ideia, Conceito, Piloto, Mercado 


\section{CRONOGRAMA}

- Fase 1: alinhamento de expectativas e levantamento de requisitos -2 meses.

- Fase 2: Desenvolvimento de protótipo - 4 meses.

- Fase 3: Prova de conceito e implantação em escala piloto - 3 meses.

- Fase 4: Implantação nacional e acompanhamento do processo - pode ser tornar um acordo de longo prazo.

É passivel de análise a postergação dos prazos informados em função do interesse da empresa na proposta apresentada.

\section{RECURSOS}

Há orçamento separado para o desenvolvimento, podendo variar de acordo com as propostas.

\section{SETOR ECONÔMICO}

Construção, informação e comunicação.

\section{CONTEXTO E ANTECEDENTES}

A empresa tem investido intensamente em informatização e automatização dos processos, em canteiros de obra e na prestação de serviços externos de assistência técnica, de modo a melhorar a eficiência e satisfação dos clientes. Como forma de planejar e acompanhar as atividades são utilizadas ordens de serviços (obra) e de manutenções (Assistência técnica), que trazem entre outras informações, o local em que será executado o serviço e a pessoa responsável. A oportunidade é de complementar essas ações com informações em tempo real dos funcionários. Foram vislumbrados sistemas com rastreamento via GPS em chips aplicados em capacetes ou crachá de identificação interligado a um sistema de monitoramento e análise. Para o acompanhamento de determinado posto de trabalho foi sugerido sensores de presença previamente instalados que comunica com o chip do colaborador (Sem Parar). Estas soluções foram vislumbradas mas ainda não foram testadas.

\section{TAGS}

Rastreamento, geolocalização, monitoramento eletrônico, controle de mão de obra, wearable, processos de display de toque screen, processo de rede ótica, roteadores de alta performance, desenvolvimento de transmissão ótico eletrônicos.

\section{RESULTADOS, ABORDAGENS OU ATRIBUTOS REQUERIDOS OU DESEJÁVEIS}

- Funcionar off-line;

- Permitir integração com outras plataformas, como por exemplo, o SAP;

- Mapear a rota e localizar o colaborador em um endereço residencial (cidade, bairro, número);

- Localizar o colaborador em posições específicas no canteiro de obras (bloco, pavimento, apartamento);

- Permitir parametrizações que criem alertas para tomada de decisão em tempo real;

- Suportar monitoramento de 200 pessoas ao mesmo tempo por equipe. Considerando todas as equipes chega a 18.000 pessoas.

\section{RESULTADOS, ABORDAGENS OU ATRIBUTOS NÃO DESEJÁVEIS}

- Dispositivos pesados ou que tragam desconfortos ao uso humano;

- Sistema e dispositivos de alta complexidade e difícil manuseio/usabilidade;

- Deseja-se que a solução não exija da pessoa monitorada o uso de smartphones ou tablets.

\section{INFORMAÇÕES RELEVANTES PARA RESPONDER A ESSE DESAFIO}

- Descrição detalhada da tecnologia aplicada; 
- Descrição do tipo de infraestrutura para utilização dos sistemas;

- Descrição dos tipos de relatórios sugeridos pelo sistema de monitoramento;

- Alcance dos dispositivos, caso tenha alguma limitação geográfica;

- Grau de maturidade da tecnologia. Informar se já foi implantada, se existem cases da utilização, se está em fase piloto, se já foi patenteada, etc.

CRITÉRIOS PARA A SELEÇ̃̃O

- Fases do projeto e valor do orçamento detalhado;

- Capacidade de pessoas monitoradas e rastreadas ao mesmo tempo;

- Compatibilidade com outros sistemas do mercado;

- Maturidade da tecnologia proposta;

- Atendimento aos parâmetros de funcionamento previamente estabelecidos.

\section{RESPOSTAS ADEQUADAS A ESTE DESAFIO}

Respostas de startups, pequenas, médias e grandes empresas, bem como de universidades, consultorias empreendedores ou investidores são bem-vindas.

FONTE: Plataforma iTec. Acesso em: out. 2016.

0 primeiro desafio aqui apresentado trata do rastreamento e monitoramento dos trabalhadores. A empresa busca um dispositivo eletrônico que ofereça a localização de cada 'colaborador' através de tecnologias de geolocalização. 0 desafio se enquadra na área da Tecnologia da Informação e Comunicação (TIC) ${ }^{77}$. Duas sugestões dadas pela própria construtora seriam a utilização de chip e ou tecnologia wearable. A tecnologia wearable (ou tecnologias vestíveis) se baseia na incorporação de microcomponentes eletrônicos em itens de vestuário, como roupas, relógios, fones de ouvido, etc. Esses dispositivos por sua vez se conectam a outros sistemas, aparelhos ou à internet. A construção civil já é um mercado representativo pra incorporação dessa tecnologia ${ }^{78}$. Já os chips funcionariam via GPS e poderiam também ser aplicados no vestuário dos trabalhadores. Nenhuma dessas soluções ainda havia sido testada pela empresa.

77 A Tecnologia da Informação e Comunicação (TIC) refere-se a recursos tecnológicos utilizados para compartilhamento e transmissão de informações, seja via informática, telefonia, redes, etc. FONTE: O QUE É TIC? Disponivel em: <http://totlab.com.br/noticias/o-que-e-tic-tecnologias-da-informacao-ecomunicacao>/Acesso em: jan. 2018.

78 FONTE: VESTÍVEIS. Disponivel em: $<$ http://www.ipt.br/centros_tecnologicos/CETIM/colunas_tecnicas/2-tecnologias_vestiveis.htm>. Acesso em: jan. 2018. 
Atualmente, a construtora conta com cerca de 18.000 trabalhadores, sendo que em média, cada obra concentra cerca de 200 pessoas. Ainda não existe um sistema implantado para que a empresa tenha total controle sobre todos esses funcionários. O problema identificado pela Nacional é, portanto, a questão do controle massivo dos trabalhadores.

A empresa destaca que é necessário que o sistema seja aplicável em larga escala e em toda sua área de atuação geográfica. É importante também que os dispositivos utilizados sejam leves e confortáveis, uma vez que ficariam implantados no vestuário dos trabalhadores. Não era desejável também a utilização de tablets ou smartphones.

O sistema como um todo deveria prever a localização específica de cada pessoa, dentro ou fora dos canteiros e inclusive dentro das edificações, de modo detalhado, como o bloco e o pavimento em que se encontra determinado trabalhador. A partir do rastreamento, seria possível checar a produtividade das equipes e averiguar se as atividades estão ocorrendo conforme o planejamento. Além disso, essa tecnologia permitiria identificar gargalos, tempos de espera, deslocamentos, etc. e dessa maneira, criar uma base de informações para melhoramento da organização dos canteiros.

Uma questão relevante é que o sistema proposto possa ser integrado com outras plataformas informatizadas da empresa. Nesse sentido, destaca-se o SAP, que funciona como um Sistema Integrado de Gestão Empresarial. Basicamente, o SAP79 é uma única plataforma que as empresas utilizam para concentrar todas as suas informações. Com todos os dados concentrados em um mesmo sistema, as empresas conseguem otimizar e agilizar seus processos e decisões. Ou seja, a Nacional busca um sistema de controle de trabalhadores que possa já ser integrado em seu sistema SAP.

\footnotetext{
79 O SAP é um modelo de Sistema Integrado de Gestão Empresarial que surgiu a partir do conceito ERP Enterprise Resource Planning. FONTE: O QUE É SAP E PARA O QUE SERVE? Disponível em: <https://tecnoeng.me/2014/11/10/o-que-e-sap-e-para-que-serve/>. Acesso em: jan/2018.
} 
A empresa destaca que tem realizado investimentos na área de informatização e automatização de processos e que esse sistema de controle seria uma complementação às tecnologias já implantadas. Essa proposta se enquadra, portanto, no terceiro nível de inovação descrito por Amorim (1999) que diz respeito à questão organizacional do processo produtivo. Seria uma inovação no âmbito de gerenciamento de processo que, através da Tecnologia da Informação e Comunicação, permitiria a ampliação do controle da mão de obra.

\section{DESAFIO 2}

Quadro 7 - Texto integral apresentado pela Empresa Nacional.

\section{Sistema de gestão e monitoramento de formas de alumínio para paredes de concreto}

\section{DESCRIÇÃO}

Com o intuito de informatizar o controle de estoque e localização de formas de alumínio do sistema construtivo de parede de concreto, a 'Nacional' busca um sistema eletrônico que possa realizar em massa a identificação, inspeção (avaliação de qualidade do material), rastreamento e monitoramento das formas, no momento de repasse a outras obras. Informações técnicas relevantes:

- As formas possuem grande número de peças, sendo que cada jogo (necessário para executar 1 pavimento de 4 apartamentos) possui de 2000 a 2500 peças.

- 0 processo de controle das formas possui três fases principais: 1a fase - recebimento inspeção e identificação; $2^{a}$ fase - Controle e acompanhamento durante a execução; $3^{a}$ fase - Limpeza e transferência para outra obra.

- Cada jogo de forma é reutilizado em média de 700 vezes.

\section{ÁREAS DE INTERESSE OU SUBÁREAS}

Tecnologia da Informação e Comunicação (TIC) - Desenvolvimento de Transmissão Ótico Eletrônicos

\section{OPORTUNIDADE}

Preferência para licenciamento de patente/tecnologia, joint venture, , projeto de desenvolvimento em parceria ou acordo de fornecimento.

\section{FASES DE DESENVOLVIMENTO ESPERADAS}

Ideia, Conceito, Piloto, Mercado

\section{CRONOGRAMA}

- Fase 1: alinhamento de expectativas e levantamento de requisitos - 2 meses.

- Fase 2: Desenvolvimento de protótipo - 4 meses.

- Fase 3: Prova de conceito e implantação em escala piloto - 3 meses.

- Fase 4: Implantação nacional e acompanhamento do processo - pode ser tornar um acordo de longo prazo.

É passível de análise a postergação dos prazos informados em função do interesse da empresa na proposta apresentada. 


\section{RECURSOS}

Há orçamento separado para o desenvolvimento, podendo variar de acordo com as propostas.

\section{SETOR ECONÔMICO}

Construção, informação e comunicação.

\section{CONTEXTO E ANTECEDENTES}

Após a utilização, as formas são limpas, e o jogo é montado no térreo do canteiro de obras, com intuito de verificar o quantitativo, e realizar a inspeção visual de avaliação da qualidade das peças. Somente após estas ações as formas podem ser enviadas a próxima obra. Sistema de RFID se provou inviável, pois quando as peças são montadas para realizar as inspeções necessárias, o sistema acaba por impedir a leitura do jogo completo nos casos que porventura uma peça esteja em frente à outra. Outro ponto importante é que por ser necessário fixar um chip em cada forma, no momento do manuseio e da limpeza com esponja de aço, o chip acaba sendo descolado facilmente. Estamos atualmente implementando o Micropuncionamento, onde a identificação por códigos de barras se mostrou mais viável até o momento, principalmente por ser mais resistente. Entretanto, se faz necessária a leitura individual de cada peça, ainda que por motivos de inspeção visual já teria que ser realizada.

\section{TAGS}

Sistema construtivo, parede de concreto, formas, controle de estoque e localização, rastreamento e monitoramento, identificação, produção de encapsulamento de circuito integrado, processo de rede ótica, sensores analógicos, processos de display de touch screen.

\section{RESULTADOS, ABORDAGENS OU ATRIBUTOS REQUERIDOS OU DESEJÁVEIS}

- Funcionar off-line;

- Monitorar aproximadamente 2500 peças ao mesmo tempo por jogo de forma, sendo que em média existem 30 jogos;

- Ser robusto para suportar o manuseio nas obras, no transporte e também na limpeza das formas com produtos abrasivos (esponja de aço e desmoldante);

- Ter vida útil de aproximadamente cinco anos (mesma das formas);

- Ser capaz de mapear e localizar as formas nas obras da empresa;

- Permitir parametrizações que criem alertas para tomada de decisão em tempo real.

\section{RESULTADOS, ABORDAGENS OU ATRIBUTOS NÃO DESEJÁVEIS}

- Sistema e dispositivos de alta complexidade e difícil manuseio/usabilidade;

- Tecnologias frágeis, que não suportem o transporte entre obras e dentro da mesma obra.

\section{INFORMAÇÕES RELEVANTES PARA RESPONDER A ESSE DESAFIO}

- Descrição detalhada da tecnologia aplicada;

- Descrição do tipo de infraestrutura para utilização dos sistemas;

- Descrição dos tipos de relatórios sugeridos pelo sistema de monitoramento;

- Alcance dos dispositivos, caso tenha alguma limitação geográfica;

\section{CRITÉRIOS PARA A SELEÇÃO}

- Fases do projeto e valor do orçamento detalhado;

- Capacidade de formas monitoradas e rastreadas pelo sistema ao mesmo tempo;

- Maturidade da tecnologia proposta: se o sistema ainda está em desenvolvimento, ou se já existem cases de sucesso na utilização;

- Atendimento aos parâmetros de funcionamento previamente estabelecidos. 


\section{RESPOSTAS ADEQUADAS A ESTE DESAFIO}

Respostas de startups, pequenas, médias e grandes empresas, bem como de universidades, consultorias empreendedores ou investidores são bem-vindas.

FONTE: Plataforma iTec. Acesso em: out. 2016.

O desafio 2 diz respeito a uma tecnologia que permita o monitoramento de peças de fôrmas de alumínio. Também se trata de uma solução dentro da Tecnologia da Informação e Comunicação (TIC), como no primeiro desafio. Como já descrito nos capítulos anteriores, a Nacional atualmente executa boa parte de suas obras com o sistema construtivo de paredes de concreto moldados in loco com fôrmas de alumínio. Cada jogo de fôrmas é formado por cerca de 2.000 a 2.500 peças e existem em média 30 jogos de fôrma, o que resulta em aproximadamente 75.000 peças. 0 problema colocado, portanto, é o controle de todas essas peças nas obras da Nacional.

O objetivo principal deste desafio é a informatização do controle do estoque das fôrmas, através de uma tecnologia que seja capaz de realizar o monitoramento em massa das peças. 0 fluxo dos jogos de fôrmas nas obras consiste no recebimento, inspeção e identificação das peças; depois durante sua utilização na obra; e finalmente a limpeza e a transferência para a obra subsequente. 0 controle deveria funcionar, portanto, nessas três etapas.

O controle das fôrmas era realizado manualmente, pelos trabalhadores ao final de determinada obra. Todas as peças eram montadas e os operários verificavam se o conjunto estava completo antes de ser enviado para a próxima obra. A empresa buscava, portanto, uma forma de controle eletrônico, de preferência que permitisse a leitura automática e geral das peças dos jogos de fôrmas.

Nesse sentido, no próprio desafio a Nacional cita que foi testado o sistema RFID, (Radio-Frequency Identification). Trata-se um método de identificação realizado através de sensores de rádio frequência capazes de ler dados de dispositivos chamados etiquetas RFID. Esse sistema permite uma leitura geral de todas as peças que tiverem com etiquetas RFID, de uma só vez. Ou seja, se cada uma das 2.500 peças tiverem uma etiqueta RFID e estiverem todas dentro do campo de leitura de rádio frequência, automaticamente o sistema já teria todas as informações sobre as peças, inclusive se estivesse faltando alguma. Na prática, entretanto, esse sistema não 
funcionou com os jogos de fôrmas, porque ocorreram interferências na leitura das peças.

Além disso, a Nacional frisa que o sistema deve ser fisicamente resistente, uma vez que o manuseio das fôrmas é bastante intenso. Cada jogo de fôrma, inclusive, costuma ser reutilizado 700 vezes e, portanto, a tecnologia de controle deve ter também essa durabilidade. As etiquetas RFID, entretanto, não foram suficientemente resistentes ao manuseio das fôrmas.

Outra solução apresentada pela Nacional foi o controle por micropunsionamento, ou seja, através da leitura de códigos de barras, uma vez que as etiquetas são mais resistentes e não existe o problema da interferência. Uma desvantagem é que a leitura necessariamente precisa ser feita individualmente por um operário. Já representa um avanço em relação ao controle visual das peças, entretanto, não permite a leitura massiva das peças.

0 segundo desafio, portanto, também se enquadra no nível de inovação organizacional, de acordo com a classificação de Amorim (1996), uma vez que procura tecnologias eletrônicas que auxiliem no processo de manuseio, manutenção e organização das fôrmas. Não tem qualquer ação sobre a edificação final, não sendo dessa maneira perceptível ao usuário e também não incorpora novos insumos construtivos. Interfere diretamente na gestão da obra e nos processos de controle de materiais.

\section{DESAFIO 3}

Quadro 8 - Texto integral apresentado pela Empresa Nacional.

DESAFIO 3: Material substituto para cerâmicas em revestimentos internos de pisos e paredes

DESCRIÇÃO

Com intuito de aumentar a produtividade e promover a industrialização no canteiro de obras, a 'Nacional' busca por material inovador que possa substituir a cerâmica nos revestimentos internos de pisos e paredes. 0 material a ser desenvolvido deve ter custo final aproximado ao da cerâmica. Informações técnicas relevantes:

- A empresa utiliza os métodos construtivos de parede de concreto e de alvenaria estrutural;

- As cerâmicas são instaladas em ambientes secos, como sala e quartos, e também em ambientes molhados como cozinha e banheiro;

- 0 consumo de cerâmica é bastante elevado, sendo que atualmente a quantidade aproximada é de 2.800.000,00 m²/ano; 
- Para escalonamento industrial, um ponto importante a ser considerado é a quantidade e dispersão geográfica das obras da empresa, visto que a 'Nacional' está presente em mais de 140 cidades, de 20 estados brasileiros e no Distrito Federal. OBS.: mais detalhes no anexo.

\section{ÁREAS DE INTERESSE OU SUBÁREAS}

Outros (materiais).

\section{OPORTUNIDADE}

Preferência para contratação de serviços tecnológicos, licenciamento de patente/tecnologia, joint venture, projeto de desenvolvimento em parceria ou acordo de fornecimento.

\section{FASES DE DESENVOLVIMENTO ESPERADAS}

Ideia, Conceito, Laboratório, Piloto, Mercado

\section{CRONOGRAMA}

- Fase 1: alinhamento de expectativas e levantamento de requisitos - 1 mês.

- Fase 2: Desenvolvimento de protótipo - 3 meses.

- Fase 3: Prova de conceito e implantação em escala piloto - 3 meses.

- Fase 4: Início da produção do material e acompanhamento do processo - 6 meses.

É passível de análise a postergação dos prazos informados em função do interesse da empresa na proposta apresentada.

\section{RECURSOS}

Há orçamento separado para o desenvolvimento, podendo variar de acordo com as propostas.

\section{SETOR ECONÔMICO}

Construção.

\section{CONTEXTO E ANTECEDENTES}

As cerâmicas sempre foram utilizadas nos revestimentos internos de pisos e paredes das unidades habitacionais da empresa, principalmente por ter custo baixo que é viabilizado em função da utilização em larga escala. Visto da necessidade de maior industrialização do canteiro, a empresa iniciou a busca por material que promovesse maior rendimento da mão de obra e baixos índices de patologia. Contudo, as soluções estudadas até o momento, compensado de alta pressão (fórmica) e revestimento vinílico, não se apresentaram economicamente viáveis, sendo que o custo destes materiais é de $\mathrm{R} \$ 20,00$ a $\mathrm{R} \$$ $30,00 / \mathrm{m}^{2}$.

TAGS

Piso, parede, revestimento, industrialização, aumento de produtividade, nanotecnologia, nanomateriais, nanocompósitos.

\section{RESULTADOS, ABORDAGENS OU ATRIBUTOS REQUERIDOS OU DESEJÁVEIS}

- Produto deve ser normatizado ou possuir SiNAT (Sistema Nacional de Avaliação Técnica de Produtos Inovadores);

- Deseja-se que o produto consiga suprir a demanda de fornecimento para média de 230 obras/ano;

- Deseja-se que o produto seja aplicável a todo território nacional.

\section{RESULTADOS, ABORDAGENS OU ATRIBUTOS NÃO DESEJÁVEIS}

- Produto que não esteja em conformidade com as normas dos órgãos financiadores (Caixa Econômica Federal e Banco do Brasil); 
- Produto que não apresente uma proposta consistente para alcançar a viabilidade econômica do material.

INFORMAÇÕES RELEVANTES PARA RESPONDER A ESSE DESAFIO

- Descrição detalhada do material apresentado;

- Resultados dos testes exigidos nas normas pertinentes e/ou demais testes já desenvolvidos do material apresentado;

- Plano de escalonamento industrial. OBS.: A 'Nacional' está presente em mais de 140 cidades, de 20 estados brasileiros e no Distrito Federal.

CRITÉRIOS PARA A SELEÇÃO

- Fases do projeto e valor do orçamento detalhado;

- Maturidade da tecnologia proposta: se o produto ainda está em fase de testes, se já foi normatizado, ou se já está em processo de produção.

RESPOSTAS ADEQUADAS A ESTE DESAFIO

Respostas de empreendedores, e empresas de pequeno e grande porte, conforme exemplificado na relação abaixo:

- Empresa fabricante de revestimento para edificações;

- Empresa fabricante de materiais;

- Universidades ou institutos de pesquisa.

FONTE: Plataforma iTec. Acesso em: out. 2016.

O terceiro desafio proposto pela Nacional busca um material substituto para o revestimento cerâmico de pisos e paredes dos empreendimentos. 0 principal objetivo, já anunciado imediatamente, é o aumento da produtividade. Espera-se um novo material, que possa ser aplicado em larga escala, em todas as obras da construtora e que tenha um custo aproximado ao custo da cerâmica. A questão central, portanto, não é a redução do custo, mas sim a redução do trabalho humano empregado nesta atividade.

Evidentemente, o material deve atender às normas de desempenho e apresentar pouca patologia. A cerâmica se trata de um material já bastante consolidado, passível de aplicação em larga escala e também com desempenho bastante satisfatório do ponto de vista tecnológico. Entretanto, ainda demanda um trabalho manual excessivo para os padrões da Nacional.

Nesse sentido, a empresa apresenta duas soluções que já foram testadas, mas se mostraram inviáveis devido ao custo. Trata-se do compensado de alta pressão e do revestimento vinílico, ambos com custos acima do esperado. 
Diferentemente dos outros desafios, esta proposta se volta à inovação de produtos para a construção. Não se trata de uma tecnologia que busca o desenvolvimento gerencial, mas sim um novo material que otimize o processo produtivo. De certo modo, esse novo produto representaria uma mudança também no produto final e poderia ser perceptível ao usuário e até ter impacto no mercado. Entretanto, a busca principal da empresa construtora é pela produtividade, pelo desenvolvimento do processo de produção da edificação. Assim, é possível compreendê-la no segundo nível da classificação de Amorim (1996), de inovação de produtos para a construção. Em resumo, os três desafios foram elaborados partindo da análise da própria empresa sobre seu processo produtivo. A identificação de pontos críticos levou a Nacional à busca de soluções diretas através de tecnologias inovadoras. De acordo com a classificação de Amorim (1996), podemos enquadrar os desafios da Empresa Nacional nos dois últimos níveis de inovação, ou seja, naqueles que dizem respeito ao processo produtivo e não à edificação propriamente dita. As propostas que se referem aos dispositivos de controle de trabalhadores e peças de fôrmas podem ser consideradas como inovações organizacionais. Trata-se da busca por soluções que impactam diretamente o processo produtivo, não dependem de um novo produto específico da construção civil e também não são acessíveis aos usuários finais das edificações. Ambos os desafios estão diretamente inseridos na área da Tecnologia da Informação e Comunicação (TIC), como mencionado. Já o desafio referente à substituição dos revestimentos cerâmicos se insere no segundo nível, de inovação de produtos para a construção, e visa principalmente o aumento da produtividade e se enquadra na área de desenvolvimento de materiais.

No quadro a seguir procuramos sintetizar as propostas dos desafios da Empresa Nacional, com o nível esperado de inovação, o meio tecnológico e as respectivas finalidades. 
Quadro 9-Resumo das propostas de desafios da Empresa Nacional e suas especificidades.

\begin{tabular}{l|l|l|l}
\hline Desafio & Nível & Meio & Finalidade \\
\hline 1 & De processo & TIC's & Aumento do controle de mão de obra \\
\hline 2 & De processo & TIC's & Aumento do controle recursos materiais \\
\hline 3 & De produtos para a construção & $\begin{array}{l}\text { Novos } \\
\text { materiais }\end{array}$ & Redução do trabalho humano \\
\hline
\end{tabular}

FONTE: Elaboração própria a partir de dados coletados na plataforma iTec e nas referências bibliográficas citadas (2018).

\subsection{A racionalização e a padronização como perspectivas da Empresa Nacional}

Os desafios aqui analisados reafirmam alguns objetivos da Empresa Nacional já anteriormente identificados durante a pesquisa de campo. A racionalização e a padronização são processos fundamentais dentro da produção da empresa e as propostas de desafios demonstraram que ambas as estratégias continuam tendo grande relevância no caminho de desenvolvimento da construtora. É através dessas ações que a Nacional procura atingir seus principais objetivos: a produção em larga escala, o aumento da produtividade e a simultaneidade temporal das obras com diversidade geográfica da produção.

Recuperando sucintamente a conceituação de Sabbatini (1989), entende-se que o processo de racionalização se traduz no conjunto de ações pensadas para a otimização da produção, seja em relação aos recursos materiais, financeiros, organizacionais, etc.

A partir da leitura e análise dos desafios apresentados pela Empresa Nacional, é possível identificar uma clara estratégia de racionalização da produção através de duas frentes: gestão e monitoramento eletrônico; implementação de novos materiais. Uma premissa da racionalização é justamente a análise do processo produtivo, visando identificar pontos críticos, falhas e gargalos e assim, buscar soluções que otimizem a produção. As inovações tecnológicas buscadas pela 
Empresa Nacional, portanto, podem ser entendidas como ações dentro de um processo mais amplo de racionalização ${ }^{80}$.

No site ${ }^{81}$ de uma empresa de desenvolvimento de softwares e aplicativos para comunicação na construção civil, são listadas oito tecnologias consideradas novidades no ramo da construção civil: impressão 3D; sensores vestíveis; contrapiso autonivelante; bioconcreto; gestão sustentável da água; rastreamento de ferramentas; drones; comunicação móvel em projetos. Dentre tais tecnologias tanto os sensores vestíveis quanto o rastreamento de ferramentas são passíveis de serem aplicados nos dois primeiros desafios propostos pela Nacional. Isso indica que a construtora está procurando absorver em seu processo produtivo as principais inovações disponíveis para o setor da construção civil. Além da racionalização, os três desafios revelam outra perspectiva da Empresa Nacional: a padronização dos processos produtivos.

No primeiro desafio, a empresa busca um sistema de monitoramento de 18.000 trabalhadores, sendo até 200 ao mesmo tempo no mesmo canteiro de obras. Da mesma maneira, o segundo desafio traz a proposta de monitoramento das peças das fôrmas de alumínio que seja aplicável a cerca de 30 jogos de fôrmas com 2.000 a 2.500 peças cada um - isso significa um sistema de monitoramento para até 75.000 peças. Finalmente, o último desafio busca um produto que possa substituir a cerâmica nas obras da empresa - que atualmente corresponde a um consumo de 28.000.000,00 $\mathrm{m}^{2}$ em aproximadamente 230 obras por ano. Os números são bastante expressivos. 0 fator da escala é, portanto, uma questão central no planejamento da empresa. A busca por soluções que sejam implementadas em um número elevado de canteiros de obras, com elevado número de trabalhadores, é um indicativo que empresa pretende manter a larga escala de produção.

\footnotetext{
${ }^{80}$ Conforme discutimos no capítulo 1, recentemente a racionalização na construção civil foi marcada pela adoção de algumas estratégias do toyotismo ou do modelo japonês, partindo da análise do processo produtivo e do diagnóstico de pontos críticos e de erros, para depois desenvolver novos procedimentos a fim de otimizar os processos.

81 INOVAÇÃO NA CONSTRUÇÃO CIVIL. Disponivel em: https://constructapp.io/pt/inovacao-na-construcaocivil-7-novidades-que-voce-precisa-conhecer/. Acesso em: jan. 2018.
} 
A empresa frisa também que procura soluções que possam ser implementadas em todo o território nacional, uma vez que sua atuação se estendeu a todas as regiões do país. Isso indica que a Nacional não busca soluções pontuais, mas sim tecnologias que se apliquem a toda sua produção. Trata-se de uma iniciativa coerente com outras estratégias já consolidadas da construtora, que mantém uma busca constante pela padronização dos processos em todas as suas obras.

Outra questão comum aos desafios é que todos eles, mesmo que indiretamente, visam otimizar e agilizar o processo produtivo, seja em relação à gestão da mão de obra e de equipamentos ou ao próprio método de execução. Esta estratégia tem a ver com o aumento da produtividade dentro do canteiro de obras.

No caso da gestão dos trabalhadores, o aumento no controle e na fiscalização através de dispositivos eletrônicos significa alcançar maior eficiência no processo de trabalho com a redução de esperas, poros de jornadas, etc. Em relação ao controle das fôrmas, a informatização do processo representa também maior eficiência no uso do material e maior agilidade, o que também recai sobre a produtividade. Finalmente, a procura por um material substituto dos revestimentos cerâmicos talvez seja a situação mais clara de busca pela eficiência do processo. Nesse desafio, a empresa não se interessa pela redução de custo do material, mas sim pela agilidade no processo de execução. 0 material substituto deveria ser de fácil aplicação, a partir de etapas mais rápidas do que o assentamento da cerâmica.

Por fim, cabe ressaltar que em todos os desafios propostos a Empresa Nacional demonstrava preferência por soluções em parcerias. Um dos termos utilizados - o "joint-venture"82 - inclusive, se refere a uma modalidade de empreendimento conjunto. Ou seja, remete à ideia de parceria, seja entre empresas de um mesmo setor ou de setores distintos. É uma maneira de fomentar a transferência de tecnologias entre empresas distintas, mesmo que juridicamente as empresas sejam independentes, tanto do ponto de vista do capital quanto de gestão.

82 O QUE É JOINT VENTURE? Disponível em: < http://www.administradores.com.br/noticias/negocios/oque-e-joint-venture/102327/>. Acesso em: jan. 2018. 
A pesquisa de campo já apontava que a Nacional baseava seu desenvolvimento em estratégias de racionalização e padronização, sem almejar a industrialização plena da produção - com iniciativas de mecanização ou pré-fabricação externa aos canteiros, por exemplo. A participação na Plataforma iTec acabou reafirmando nossas observações de campo, uma vez que explicita a busca da empresa por tecnologias que permitam avanços em relação à gestão e controle e também que sejam expansíveis a toda sua produção. 


\section{CONSIDERAÇÕES FINAIS}

Como colocado no início desta dissertação, o setor da construção civil tem participação fundamental na economia do país com destaque para a esfera da produção habitacional. Inúmeros estudos analisaram a questão da habitação tanto do ponto de vista das políticas públicas quanto sobre o seu processo produtivo.

Os momentos de maior desenvolvimento da ICCSE correspondem também aos períodos de maior produção habitacional do país. A construção de moradias foi impulsionada e intensificada na época do BNH. Foram mais de quatro milhões de unidades produzidas a partir de recursos públicos. Para atender a essa demanda as construtoras buscaram estratégias que permitissem o aumento da produtividade. Foi um período marcado por tentativas pontuais de racionalização da produção e também pelo desenvolvimento da indústria de materiais para a construção. De acordo com Villela (2007), esse momento corresponde à terceira fase do desenvolvimento da ICCSE no Brasil, justamente caracterizado pelo início da implementação dos preceitos toyotistas de racionalização da produção (VILLELA, 2007).

Na década de 1990, Farah (1992) já havia identificado diversas estratégias de racionalização na produção habitacional. A questão do planejamento dos processos 
produtivos começou a ter relevância para as empresas construtoras assim como a busca pela ampliação do controle nas obras. Com base na análise de Farah (1992), Villela (2007) elencou as nove estratégias - o que ele chamou de "modos de socialização" - que estavam presentes na ICCSE já a partir dos anos 1970, e que se basearam nos princípios do modelo japonês. Recuperando-se sucintamente, são: $1^{\text {o }}$ ) Lean Production - Lean Construction; 2으 ) Programas de Qualidade Total; 3으 Racionalização dos processos de trabalho em escritório; 4ํㅜㄱ Logística e Racionalização do canteiro de obras; 5ํㅜ $)$ Horizontalização das empresas; 6ำ) Learning Organization; 7ํㅜㄱ Gestão participativa; 8욱 Políticas de engajamento e fixação dos trabalhadores à empresa; 9ํㅜ) Terceirizações.

Conforme debatemos mais enfaticamente no capítulo 1 desta dissertação, boa parte dos estudos sobre a ICCSE desenvolvidos a partir da década de 1970 encarava o setor como um exemplo de atraso frente às demais forças produtivas do país. É inegável que as atividades da construção no Brasil carregam um histórico de precariedades, seja em relação às condições de trabalho ou ao processo produtivo como um todo. Esse contexto fomentou o argumento de que o avanço da ICCSE dependia de um processo mais intenso de industrialização, seguindo os modelos clássicos adotados por grande parte dos setores industriais. Os esforços deveriam se voltar, portanto, à organização do trabalho - ou seja, à administração científica e à mecanização. 0 setor da construção civil é marcado, todavia, por especificidades que o diferem substancialmente de outras indústrias, a começar pelo canteiro de obras que é o suporte de toda a produção. Ao contrário de outros setores que organizam seus processos na fábrica - fechada e controlada -, as atividades da construção civil se desenvolvem no canteiro, um espaço mutante, que precisa ser adaptado a cada etapa da obra. A grande variabilidade das tarefas produtivas também é um fator marcante na ICCSE. Além disso, se coloca a questão da particularidade do produto final, a edificação. Por fim, mas não menos importante, existe o fator da sobreposição da dimensão imobiliária sobre a produtiva para a obtenção do lucro. Tudo isso desencorajava as empresas a despenderem esforços e investimentos em soluções tecnológicas. 0 resultado é que os avanços mais notáveis na produção da ICCSE ocorreram no âmbito da organização e controle do processo produtivo e da sua gestão. 
Entre as décadas de 1970 e 1990, as construtoras passaram progressivamente a incorporar ações que buscavam otimizar o processo produtivo, reduzir custos e desperdícios e aumentar a produtividade. É possível destacar: a ampliação do controle sobre os processos de trabalho; a análise do processo produtivo para a identificação de falhas, erros e gargalos; o planejamento das atividades com base no diagnóstico anterior; e a retirada de algumas atividades do interior dos canteiros de obras, bem como iniciativas de pré-fabricação.

Esse processo não ocorreu de maneira homogênea na ICCSE e também não significou a superação dos problemas denunciados nas análises sobre a construção civil. O trabalho continuou parcelizado e a subempreitada e a terceirização passaram a ser ainda mais comuns. Do ponto de vista de organização e gestão, contudo, pode-se dizer que ocorreram avanços.

A partir dos anos 2000 foi possível observar a consolidação e a intensificação do processo de racionalização na ICCSE, principalmente no que se refere à produção da habitação. Esse período foi marcado pelo aumento da participação do setor privado na produção habitacional para baixa renda. Ocorreu inclusive um alinhamento inédito entre o Estado, o setor financeiro e a construção civil que possibilitou uma escala de produção de moradias em um curto período de tempo até então não alcançada no Brasil ${ }^{83}$ (SHIMBO, 2016).

O cenário, que já era favorável para a promoção e produção habitacional no início dos anos 2000, se mostrou ainda mais otimista com o lançamento do PMCMV em 2009. Somente na primeira fase do programa foi prevista a construção de um milhão de moradias a serem produzidas pelo setor privado através de fundos públicos. As empresas construtoras vislumbraram um terreno bastante fértil para ampliar a produção e para isso buscaram a racionalização do processo produtivo.

A questão que se colocou desde o início deste trabalho de pesquisa foi justamente como se possibilitou, no âmbito do canteiro de obras, tamanha escala de produção

8383 Shimbo (2016) ressalta que tal processo é recente, mas que compõe uma tendência global que segue a lógica de maximização de lucros, na qual o caráter 'mercadoria' da habitação é exacerbado (SHIMBO, 2016). 
em um curto período de tempo. A hipótese elaborada, a princípio, era que as empresas construtoras utilizaram um sistema "híbrido" de produção, ainda mantendo aspectos manufatureiros, mas com estratégias de industrialização e com ações avançadas de controle, sob influência do contexto mais geral da financeirização. Durante a pesquisa de campo, perseguimos a seguinte questão: as empresas construtoras da produção habitacional de larga escala tinham maior ou menor tendência pela industrialização?

As visitas aos canteiros dos empreendimentos realizadas em conjunto com a pesquisa bibliográfica e documental e posterior trabalho analítico nos permitiram construir algumas ponderações. A produção recente da habitação em larga escala é marcada por um intenso processo de racionalização, que se baseia principalmente no avanço das estratégias de organização e gestão, bem como na ampliação do controle sobre o processo produtivo.

Um aspecto fundamental na produção analisada é a questão do planejamento que exige, consequentemente, por parte das empresas, o diagnóstico das atividades produtivas a partir da identificação de falhas e erros. A etapa do planejamento era essencial nas obras estudadas e se colocava em vários níveis do processo. Identificamos estratégias de planejamento em âmbito global das obras; em relação ao fornecimento de materiais; e na questão da organização e logística do canteiro.

O planejamento global do processo produtivo passava pela elaboração do cronograma, pela organização e compatibilização das atividades a serem realizadas, e também pela organização das equipes de trabalho. 0 planejamento do fornecimento de materiais e insumos era também essencial para as construtoras, uma vez que as empresas procuravam trabalhar com os menores estoques possíveis, e qualquer atraso era bastante indesejável. Finalmente, vale destacar a importância da organização e da logística dos canteiros de obras. Um exemplo claro é a estratégia da Empresa Nacional de executar obrigatoriamente toda a infraestrutura do empreendimento - a infra $360^{\circ}$ - antes mesmo do início da construção dos edifícios.

Outra questão recorrente nas obras analisadas diz respeito à retirada de processos do local onde serão construídas as edificações, além da utilização de componentes pré-fabricados e industrializados. Em todos os canteiros de obras estudados, existiam bases específicas para a preparação de materiais e para pré-fabricação de 
componentes. A utilização de kits prontos - hidráulicos, elétricos, do sistema de cobertura e de portas e janelas - era também uma estratégia comum das construtoras.

Em relação à pré-fabricação, vale destacar a produção das lajes realizada pela Nacional na obra ALV_APTO. 0 processo convencional de execução de lajes, a partir da concretagem diretamente no respectivo pavimento, demanda um tempo considerável de espera da cura do concreto até que se possa dar prosseguimento aos pavimentos superiores. Fabricar as lajes em uma base, no próprio canteiro, significa expressiva vantagem em relação ao andamento da obra.

Outro ponto relevante nos processos de racionalização observados refere-se à gestão da mão de obra. Ainda é notável a predominância da subempreitada e da terceirização dos serviços dos canteiros. As equipes são especializadas e o trabalho continua parcelizado.

Alguns instrumentos de controle de qualidade e de prescrição de serviços também tinham relevância na organização da produção. A Empresa Nacional, por exemplo, se utilizava do "Farol de Qualidade", um quadro em que era apresentada a avaliação de cada tipo de serviço da obra. Trata-se de uma maneira de identificar quais são as falhas do processo produtivo e de estimular as equipes a corrigi-las. Vale também destacar o Procedimento de Execução e Serviço (PES), que norteava a execução de todos os serviços de todas as obras da construtora. É uma estratégia que objetiva padronizar o processo produtivo e também o gesto dos trabalhadores. Para desenvolver cada PES, a empresa precisou estudar cada tipo de serviço de modo a determinar a melhor forma de execução e finalmente detalhar o método a ser utilizado. Tal estratégia reduz consideravelmente o espaço para improvisos - o que costuma ser comum dentro dos canteiros de obras. Independentemente do empreendimento e da equipe que estará executando determinado serviço, o processo deverá ser o mesmo. Do mesmo modo, a Regional se utilizava de estratégias similares de controle de qualidade e de produtividade, apesar dos instrumentos não serem tão avançados quanto os da Nacional. Entretanto, existiam nas obras, estatísticas de desempenho que expunham os aspectos positivos e negativos dos processos de execução e indicavam o que precisava ser melhorado. 
Foi possível observar iniciativas pontuais de mecanização em alguns canteiros, como a utilização de máquinas e equipamentos de grande porte. Mas, em grande parte dos casos, o emprego dessas máquinas não se tratava de uma estratégia explícita na direção da mecanização e ainda menos da automatização dos processos produtivos como um todo.

Compreendendo a industrialização da construção como a junção entre um conjunto de técnicas de racionalização e a mecanização da produção, é possível admitir que a produção atual da ICCSE, particularmente, a produção em larga escala da habitação, não se coloca ainda como uma atividade industrializada. A hipótese elaborada inicialmente, portanto, não pôde ser comprovada sob todos os aspectos. Em contrapartida, o avanço dos processos racionalizados é expressivo, sendo que as empresas construtoras estão direcionando esforços e investimentos justamente para o desenvolvimento de formas mais avançadas de organização, gestão e controle da produção.

No caso da Empresa Nacional, a participação na Plataforma iTec reforça o argumento de que a questão da racionalização é central no processo produtivo recente da construtora. Os desafios lançados pela empresa na plataforma evidenciam a busca por estratégias de controle - tanto da mão de obra quanto de materiais - através da tecnologia da informação. É um indício de que a Nacional se coloca na busca por avanços tecnológicos, porém, mais expressivamente dentro da esfera de gestão e controle do que na esfera da produção em si.

Outra ponderação diz respeito à crescente utilização das paredes de concreto na produção habitacional em larga escala. Até recentemente, a escolha pela alvenaria estrutural para execução desse tipo de empreendimento era a mais comum. Mas então, quais os fatores que colaboraram para a incorporação de um sistema construtivo até então pouco utilizado no Brasil na produção habitacional? Grande parte das empresas construtoras que atuam no ramo da construção de moradias principalmente destinadas à baixa renda -desenvolveu expertise na execução do sistema de alvenaria estrutural. Se tomarmos a Empresa Nacional como exemplo uma das maiores produtoras de habitação para o segmento econômico no Brasil foram décadas de experiência e aprimoramento no trabalho com a alvenaria autoportante. 
Shimbo (2012) enfatizou a utilização da alvenaria estrutural pela Empresa Nacional, que considerava que a grande vantagem desse sistema era a eliminação de diversas etapas de execução em relação à construção convencional.

\begin{abstract}
Desde a década de 1970, a ECP 84 adota a alvenaria estrutural como sistema construtivo na maioria de suas obras [...] Segundo o engenheiro da obra, a ECP começou com a alvenaria estrutural, criou um know-how e continuou com esses sistema construtivo. Tanto ele como o mestre consideram que esse tipo de sistema construtivo 'desenvolve melhor', se comparado à estrutura em concreto armado e alvenaria de vedação. Isso porque o edifício vai subindo com todas as etapas em conjunto. Na medida em que a alvenaria estrutural é elevada vão se instalando batentes e janelas, executando o reboco interno e o gesso. (SHIMBO, 2012, p.147).
\end{abstract}

A Nacional dominava, portanto, essa tecnologia construtiva, desde a cadeia de fornecedores, até as equipes de trabalhadores. Mesmo com toda a experiência acumulada, a construtora optou por incorporar também as paredes de concreto em seu portfólio, sendo que o investimento inicial das fôrmas era expressivo.

Para que o sistema construtivo de paredes de concreto fosse um modelo produtivo vantajoso economicamente, as fôrmas de alumínio precisavam ser reutilizadas ao máximo. Para isso, dois requisitos estiveram presentes: repetição e padronização. Antes mesmo do lançamento do PMCMV, no início dos anos 2000, as empresas construtoras já haviam diagnosticado um novo nicho de mercado que teria exatamente como base a repetição e a padronização, que era o chamado 'segmento econômico'. Quando surgiu o PMCMV, portanto, o terreno para a produção em escala da moradia para os setores de baixa renda já era um espaço explorado pelas construtoras e incorporadoras. 0 que ocorreu foi a ampliação vertiginosa tanto do número de empreendimentos quanto do número de unidades habitacionais.

Além do programa habitacional, o Financiamento de Máquinas e Equipamentos (Finame), do BNDES enquadra as fôrmas de alumínio em seu escopo, o que facilita a aquisição destes equipamentos pelas construtoras. Segundo reportagem da revista Construção Mercado, esse financiamento "oferece até 24 meses de carência para o pagamento e estende o prazo de quitação em até dez anos com juros que variam de 
6,5\% a 9,2\% ao ano" 85 . Não foi possível aferir se as empresas pesquisadas se utilizaram desse financiamento para a compra das fôrmas, mas sem dúvida se trata de uma facilitação para a implementação desse sistema construtivo.

Não por acaso, as construtoras perceberam que deveriam acelerar o ritmo de produção e aproveitar o momento de 'boom' imobiliário fomentado por uma política governamental. Justamente foi nesse período que apareceram com maior destaque as obras executadas com paredes de concreto. A Empresa Nacional iniciou a experiência com este sistema em 2008 e teve seu primeiro empreendimento concluído com paredes de concreto em 2010. A partir daí, a utilização do sistema foi crescente. Nessa primeira experiência, a construtora utilizou fôrmas alugadas, outra estratégia possível. Na mesma reportagem, o então gestor de obras da Empresa Nacional em São Paulo, afirmou que os testes com as paredes de concreto foram iniciados devido à escassez de mão de obra - necessária no trabalho da alvenaria estrutural - e também à necessidade de acelerar a produção. Ele ainda afirmava que quando houvesse escala de produção, a tendência seria comprar as fôrmas.

\footnotetext{
“A afirmação baseia-se na redução de prazo de construção alcançada pela empresa ao substituir alvenaria por paredes de concreto executadas com fôrmas de alumínio. No caso em questão, um prédio com 440 apartamentos foi concluído em 12 meses. Se fosse em alvenaria, o prazo previsto seria de 18 meses. São seis meses a menos de custos com funcionários, locação de equipamentos e encargos sociais. 'Ao reduzir o tempo de construção e também a quantidade de pessoas trabalhando, o custo diminui. Dependendo da escala do empreendimento, o custo do imóvel pode cair até 30\%', afirma Pereira". (Construção Mercado, 2011)
}

As obras da construtora visitadas recentemente em Araraquara e São Carlos para essa pesquisa confirmam a previsão do gestor. A escala de produção foi ampliada e a Nacional de fato comprou as fôrmas e cada vez mais expande sua utilização. Em uma apresentação ${ }^{86}$ destinada aos investidores divulgada no início deste ano, em 2018, a Empresa Nacional destaca o ganho de produtividade alcançado desde a implementação das paredes de concreto em suas obras. De acordo com os dados

85 Reportagem Construção Mercado: “Fôrmas de alumínio", 2011. Disponível em: <http://construcaomercado.pini.com.br/negocios-incorporacao-construcao/121/artigo282536-1.aspx>. Acesso em: Ago. 2017.

86 Apresentação Institucional da Empresa Nacional, jan. 2018. 
apresentados, a execução das paredes de concreto demanda menor número de trabalhadores para execução de cada unidade se comparado à execução da alvenaria estrutural. A empresa alcançou também maior velocidade de produção com este sistema construtivo, novamente se comparado à alvenaria estrutural.

O gráfico a seguir demonstra como a empresa, desde 2013, vem melhorando seus índices de produtividade a partir da diminuição do número de trabalhadores necessários para a produção de uma unidade habitacional e da elevação da velocidade de produção das obras. A construtora inclusive faz uma comparação de seu desempenho no ano de 2017 considerando sua produção completa - com os sistemas de alvenaria estrutural e de paredes de concreto - e sua produção apenas com as paredes de concreto. 0 sistema executado com as fôrmas de alumínio leva considerável vantagem em relação à produtividade sobre o sistema convencional em alvenaria.

Gráfico 9 - Evolução do PI x OS da Empresa Nacional.

- IP Anual $=$ VP Anual (\%)

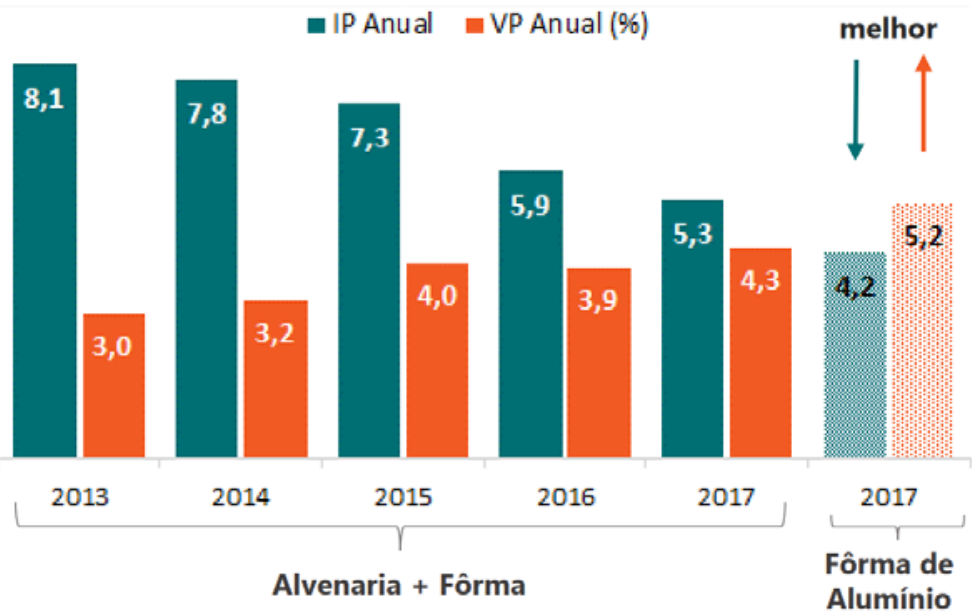

IP (Índice de Produtividade): Demonstra quantas pessoas são necessárias para produzir uma unidade. A orientação é quanto menor o indicador, melhor o resultado.

VP (Velocidade de Produção): Demostra o \% executado por mês das obras em andamento. A orientação é quanto maior o indicador, melhor o resultado.

FONTE: Apresentação Institucional da Empresa Nacional, jan. 2017.

Não surpreende, portanto, que em um período de quatro anos, a Empresa Nacional ampliou a utilização do sistema de paredes de concreto em suas obras. No ano de 2017, 59\% das obras da Nacional foram executadas com as fôrmas de alumínio, 
sendo que a alvenaria estrutural foi empregada em $41 \%$ dos empreendimentos, conforme demonstra o gráfico a seguir.

Gráfico 10 - Evolução dos métodos construtivos da Empresa Nacional (unidades).

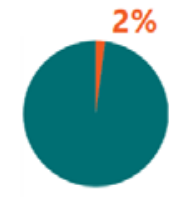

2014

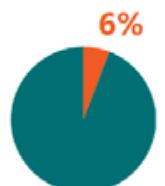

2015

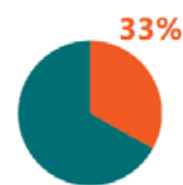

2016

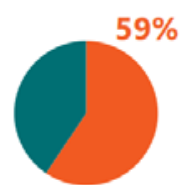

2017
+ Giro do Ativo

+ Padronização

+ Produtividade

- Estrutura Administrativa

- Discrepância de custo

FONTE: Apresentação Institucional da Empresa Nacional, jan. 2017.

Ainda na apresentação aos investidores, a Nacional afirma que a execução com as fôrmas de alumínio significa maior giro do ativo financeiro, maior padronização, e maior produtividade, alcançados com menor estrutura administrativa e menor discrepância de custo. Os dados divulgados demonstram que a empresa reduziu a quantidade de mão de obra utilizada nos canteiros e mesmo assim elevou a velocidade de produção. A Nacional enfatiza, além disso, que dentro do mercado habitacional voltado à baixa renda, ela se destaca entre as quatro maiores construtoras, acumulando $65 \%$ dos lançamentos e $60 \%$ das vendas.

Todos esses fatores indicam que, para a Empresa Nacional, a questão da alta produtividade e da larga escala de produção são fatores fundamentais. A racionalização e a padronização dos processos são as estratégias adotadas pela empresa para alcançar seus objetivos. Nesse sentido, é possível observar que a Empresa Regional tem objetivos e estratégias similares à Nacional, mas ainda não alcançou o mesmo patamar de desenvolvimento, em termos de tecnologias informatizadas. De modo geral, entretanto, do ponto de vista produtivo, as duas empresas se assemelham e utilizam técnicas similares de gestão e organização, bem como adotam materiais e componentes equivalentes em suas obras. É um indicativo de que as empresas, independentemente de seu porte, compreenderam que a produção em larga escala da habitação depende da padronização e da racionalização dos processos produtivos. 


\section{REFERÊNCIAS BIBLIOGRÁFICAS}

AMORE, C. "Minha Casa Minha Vida" para iniciantes. In: AMORE, C.; SHIMBO, L.; RUFINO, M. Minha casa... e a cidade? Avaliação do programa minha casa minha vida em seis estados brasileiros. Rio de Janeiro: Letra Capital, 1aEd., 2015, pp.11-28.

AMORIM, S. L. Inovações tecnológicas nas edificações: papéis diferenciados para construtores e fornecedores. Gest. Prod.[online]. 1996, vol.3, n.3, pp.262-274.

ANUÁRIO DA CONSTRUÇÃO. Habitação Seriada. São Paulo: Pini, p. 130-131, 2014.

ASSOCIAÇÃO BRASILEIRA DA INDÚSTRIA DE MATERIAIS DE CONSTRUÇÃO; FUNDAÇÃO GETÚlIO VARGAS. Perfil da Indústria de Materiais de Construção. ABRAMAT; FGV, 2016.

BARAVELLI, J. E. Terra, trabalho e tecnologia no programa MCMV. Tese (doutorado). Universidade de São Paulo, mai. 2014.

BARONE, R. Canteiro-escola: trabalho e educação na construção civil. São Paulo, EDUC / FAPESP, 1999.

BRASIL. Ministério do Trabalho e Emprego. NR 18 - Condições e Meio Ambiente de Trabalho na Indústria da Construção. Redação dada pela Portaria ${ }^{\circ} 4$, 4 de julho de 1995. Brasília: Ministério do Trabalho, 1995.

BRUNA, P. J. V. Arquitetura, Industrialização e Desenvolvimento. 2a Ed. São Paulo: Perspectiva, 1976.

CÂMARA BRASILEIRA DA CONSTRUÇÃO CIVIL. Catálogo de Inovação na construção civil. Brasília: CBIC, 2016.

CARNEIRO, M.; VETORAZZO, L. Crise na construção civil deixa indústria fora de recuperação. Folha de São Paulo. 02 Set. 2017. Disponível em: <http://www1.folha.uol.com.br/mercado/2017/09/1915224-crise-naconstrucao-civil-deixa-industria-fora-da-recuperacao.shtml>. Acesso em: out. 2017.

CASTRO, J. Invento \& inovação tecnológica: produtos e patentes na construção. São Paulo : Annablume, 1999.

CORIAT, B. O processo de trabalho de tipo "canteiro" e sua racionalização: observações sobre algumas tendências da pesquisa atual. In: O trabalho em 
canteiro. Plano, construção e habitat. Atas de Colóquio. Tradução: Jorge H. Oseki. Revisão: João Sette Whitaker Ferreira, 1983.

FARAH, M. F. S. Estratégias de adaptação à crise: tendências de mudança no processo de trabalho na construção habitacional. Trabalho apresentado ao Departamento de Sociologia da Faculdade de Filosofia, Letras e Ciências Humanas da Universidade de São Paulo, 1992.

Processo de trabalho na construção habitacional: tradição e mudança. São Paulo: Annablume; Fapesp, 1996.

FERRO, S. 0 canteiro e o desenho. In: Arquitetura e trabalho livre. São Paulo: Cosac Naify, 2006 [1976].

Sobre o canteiro e o desenho. In: . Arquitetura e trabalho livre. São Paulo: Cosac Naify, 2006 [2003].

FIX, M. A. B., Financeirização e transformações recentes no circuito imobiliário no Brasil. Tese (doutorado). Universidade Estadual de Campinas, 2011.

FLEURY, A.; VARGAS, N. Organização do trabalho: uma abordagem interdisciplinar e sete estudos sobre a realidade brasileira. São Paulo, Atlas. 1983.

GITAHY, M. L. C.; PEREIRA, P. C. X. O complexo industrial da construção e a habitação econômica moderna: 1930-1964. [S.l: s.n.], 2002.

GONÇALVES, R. Ciclo e tendência na construção civil. Fundação Getúlio Vargas, 2015.

HARVEY, D. Os limites do capital. São Paulo: Boitempo, 2006.

17 contradições e o fim do capitalismo. São Paulo: Boitempo, 2016.

INSTITUTO BRASILEIRO DE GEOGRAFIA E ESTATÍSTICA. Classificação Nacional de Atividades Econômicas - Versão 2.0. Rio de Janeiro: IBGE, 2010.

Pesquisa Anual da Indústria da Construção. Rio de Janeiro: IBGE, 2015.

INSTITUTO DE PESQUISA ECONÔMICA APLICADA. Estudo aponta redução do déficit habitacional. 2013. Disponível em: <http://www.ipea.gov.br/portal/index.php?option=com_content\&view=article\&id $=20656>$, Acesso em: set. 2014 .

JARAMILLO, S. Producción Del espacio contruido em Bogotá. In: Capital, estado y vivienda en la América Latina. México, D.F: Distribuiciones Fontamara, 1987. 
KOURY, A. P. Arquitetura construtiva: proposições para a produção da arquitetura no Brasil (1960-1970). Projeto História (PUCSP), v. 34, p. 189-203, 2007.

LOURENÇON, A. C. Fôrmas de alumínio. Construção Mercado, Ed. 121, ago. 2011. Disponível em: <http://construcaomercado.pini.com.br/negociosincorporacao-construcao/121/artigo282536-1.aspx>. Acesso em: Ago. 2017.

LOVERA, A. Radiografía de la industria de la construcción: el ciclo del capital. Universidad Central de Venezuela. Ediciones de la Biblioteca-EBUC. Caracas, 2011

El capital inmobiliario y constructor y la producción de la ciudad em América Latina. In: . Teorias sobre la ciudad en la América Latina. Universidad Autónoma Metropolitana, 2014.

MARICATO, E. Indústria da construção e política habitacional. 1984. 208 p. Tese (Doutorado em Arquitetura e Urbanismo). Faculdade de Arquitetura e Urbanismo, Universidade de São Paulo.

. Indústria da construção: Reflexão sobre o "atraso tecnológico". In: BOLETIM PAULISTA DE GEOGRAFIA, n. 64, São Paulo, 1986.

MARTUCCI, R. Projeto tecnológico para edificações habitacionais: utopia ou desafio? Tese (doutorado). Universidade de São Paulo, 1990.

MARX, K.. O capital: crítica da economia política. Livro 1, vol. 1, capítulos X a XIII. Rio de Janeiro: Civilização Brasileira, 2002, p. 361 a 571.

MORICE, A. Os peões da construção civil em João Pessoa. Espaço e Debate, São Paulo, n.36, p.35-46, 1992.

MOURA, A. D. S. Novas soluções, velhas contradições: a dinâmica cíclica da industrialização em sua forma canteiro. Dissertação de mestrado - Faculdade de Arquitetura e Urbanismo, Universidade de São Paulo. São Paulo, 2011.

OSCAR, N. Não vamos aguentar por muito mais tempo. Entrevista com R.M. 0 Estado de São Paulo. 08 nov. 2015.

PANAIA, M. El sector de la construcción: un proceso de industrialización inconcluso. 1. ed. Buenos Aires: Nobuko, 2004.

QUAGLiO, J. P. A produção do Programa Minha Casa, Minha Vida em São Carlos: análise do canteiro de obras promovido por grande empresa construtora. Pesquisa de Iniciação Científica - Instituto de Arquitetura e Urbanismo da Universidade de São Paulo, São Carlos, 2014. 
REPETTE, W. Concreto auto adensável: características e aplicação. Revista Téchne, ed. 135, Jun/2008. Disponível em: <http://techne17.pini.com.br/engenharia-civil/135/artigo285721-3.aspx>. Acesso em: jun/2018.

SABBATINI, F. H. Desenvolvimento de métodos, processos e sistemas construtivos: formulação e aplicação de uma metodologia. Tese de doutorado. São Paulo: Escola Politécnica da USP, 1989.

SHIMBO, L. Z. Habitação Social de Mercado: a confluência entre Estado, empresas construtoras e capital financeiro. 1. ed. Belo Horizonte: C/Arte, 2012.

Sobre os capitais que produzem habitação no Brasil. Novos Estudos: Cebrap, São Paulo, v. 35, p. 119-133, jul. 2016.

SHIMBO, L. Z. ; LOPES, J. M. de A. . Mucho mercado, poca política: el papel de las grandes empresas de la construcción en el programa Mi Casa, Mi Vida en las ciudades no metropolitanas en Brasil. Studia Politicae, v. 30, p. 5-24, 2014

STRAUSS, A.; CORBIN, J. Pesquisa Qualitativa: Técnicas e procedimentos para o desenvolvimento da teoria fundamentada. 2. ed. Porto Alegre: Artmed, 2008.

VARGAS, N. Construção habitacional: um "artesanato de luxo". In: n Revista Brasileira de Tecnologia. Vol. 12, n. 1, Brasília, 1981.

. Tendências e mudanças na indústria da construção. Revista Espaço \& Debates 36. São Paulo, NERU, 1992.

VILLELA, F. F. Indústria da construção civil e reestruturação produtiva: novas tecnologias e modos de socialização construindo o intelecto coletivo ("general intellect"). 2007. Tese (Doutorado em Sociologia) - Instituto de Filosofia e Ciências Humanas, Universidade Estadual de Campinas, Campinas, 2007. 


\section{ANEXO 1}

Caracterização dos empreendimentos analisados

\section{Canteiro 1-ALV_APTO}

- LOCALIZAÇÃo: São Carlos/SP

- SISTEMA CONSTRUTIVO: Alvenaria estrutural

- TIPOLOGIA: Apartamentos de $42 \mathrm{~m}^{2}$

- IMPLANTAÇÃO: 36 blocos de 5 pavimentos

- NÚMERO DE UNIDADES: 720 apartamentos

Imagem 90 - Inserção urbana do empreendimento ALV_APTO.

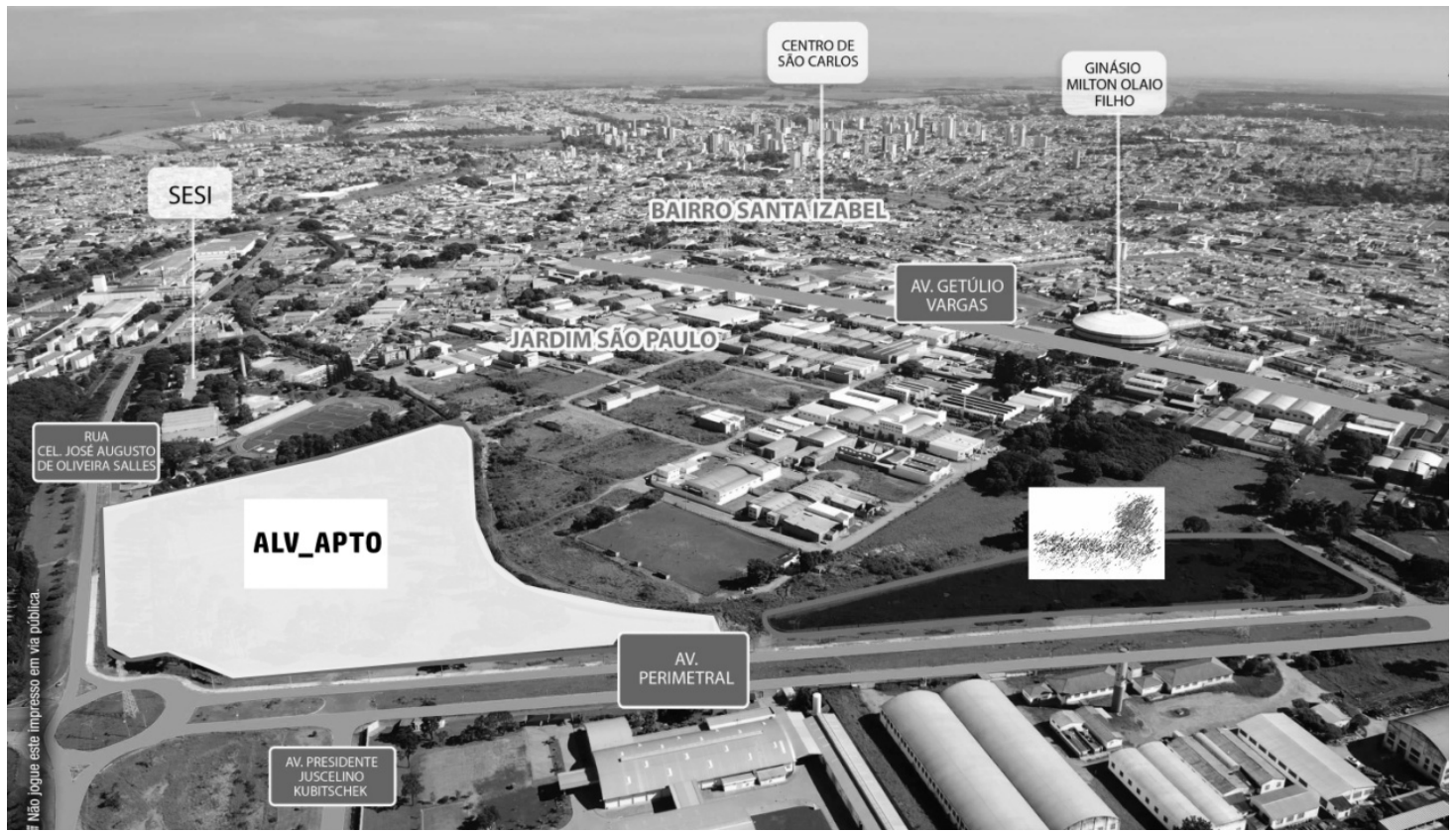

FONTE: Site da construtora, 2013. 
Imagem 91- Implantação do empreendimento ALV_APTO.

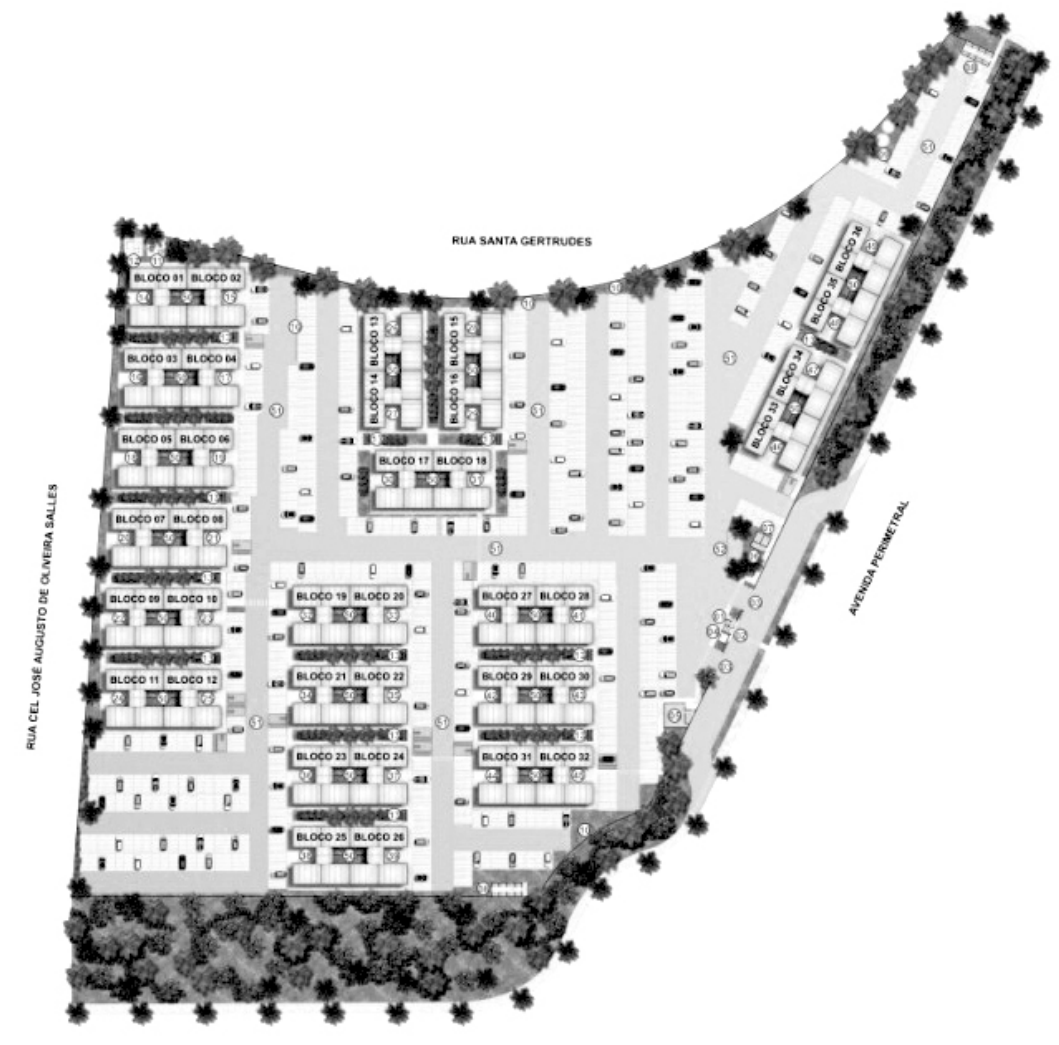

FONTE: Site da construtora, 2013.

Imagem 92 - Planta tipo ALV_APTO opção 1 e 2.

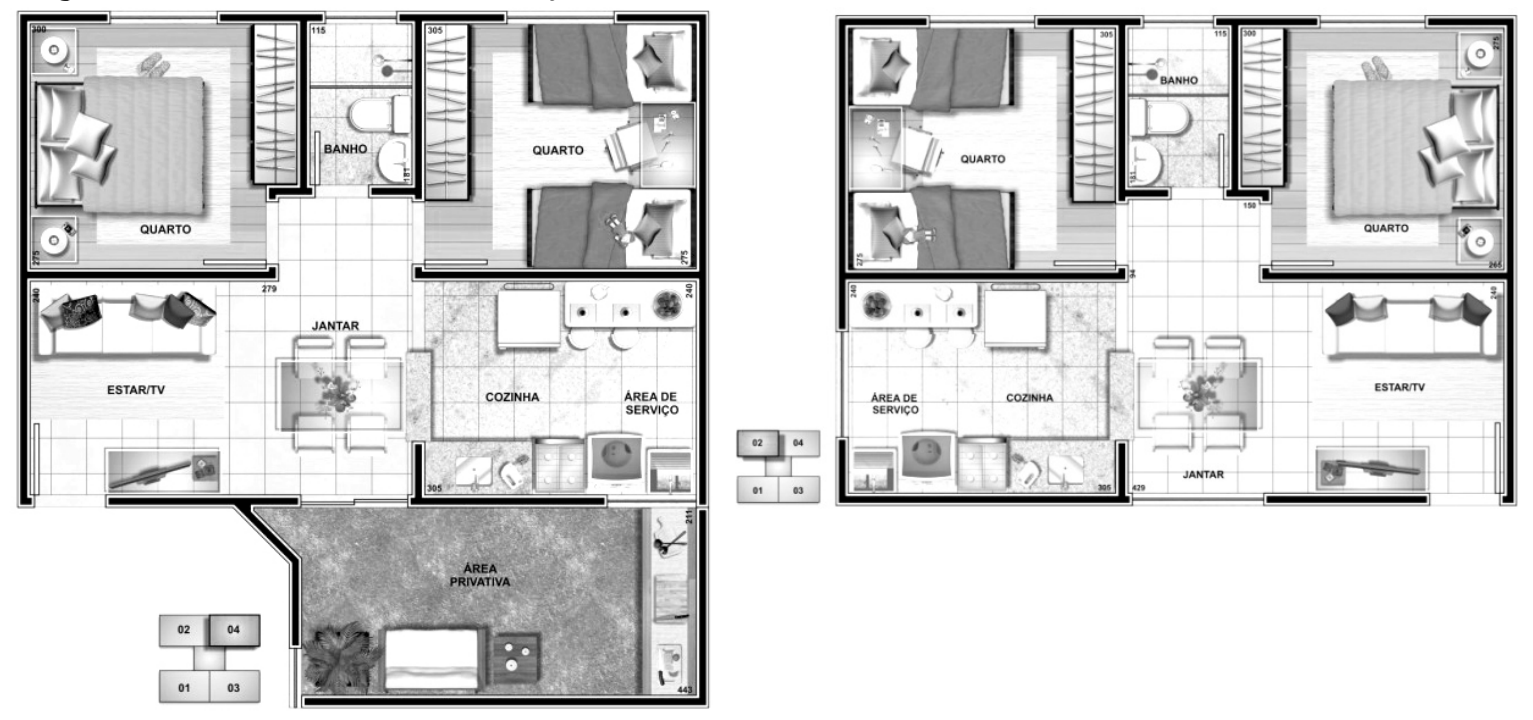

FONTE: Site da construtora, 2013. 
Canteiro 2-PC_APTO_1

- LOCALIZAÇÃO: Araraquara/SP

- SISTEMA CONSTRUTIVO: Paredes de concreto

- TIPOLOGIA: Apartamentos de $40 \mathrm{~m}^{2}$ e PNE de $50 \mathrm{~m}^{2}$

- IMPLANTAÇÃO: 21 blocos de 4 pavimentos e 1 bloco PNE de 5 pavimentos

- NÚMERO DE UNIDADES: 356 apartamentos

Imagem 93 - Inserção urbana do empreendimento PC_APTO_1.

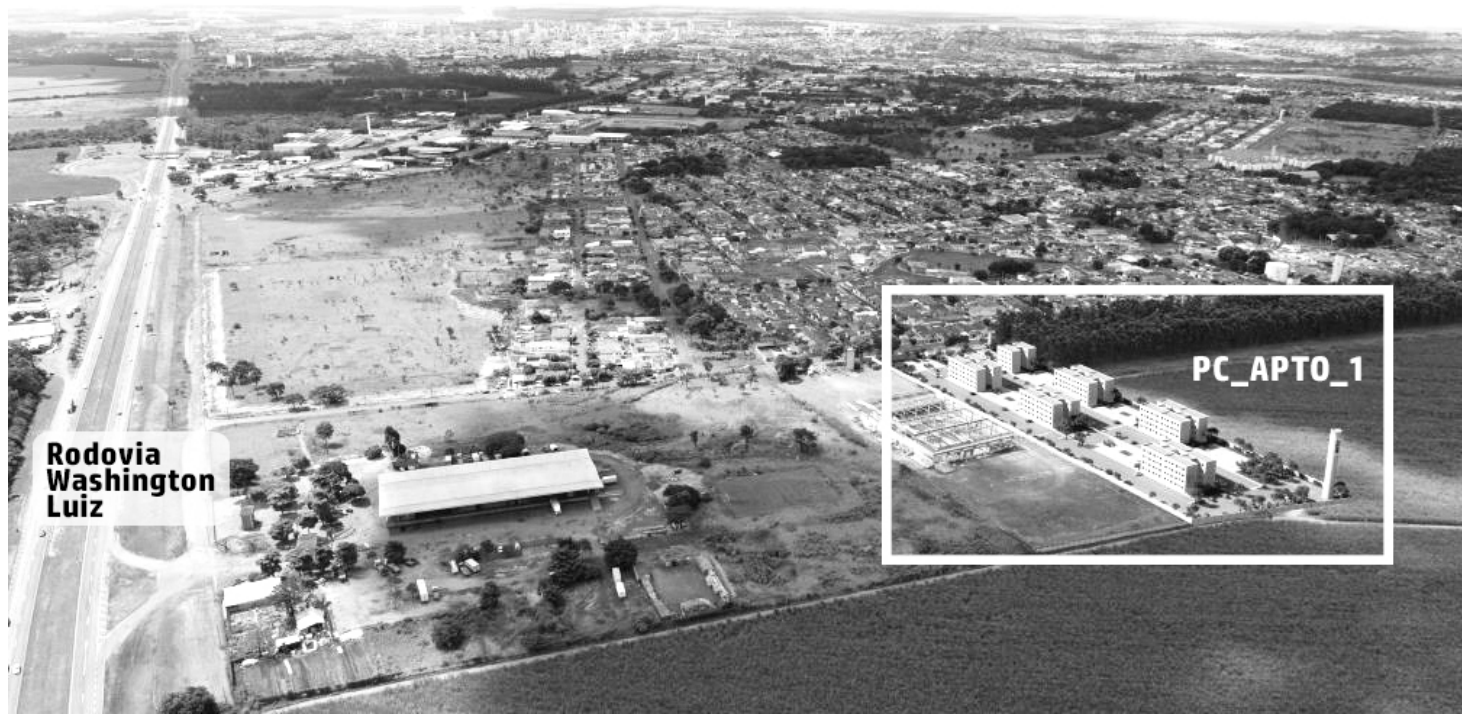

FONTE: Elaboração própria a partir de imagem divulgada pela construtora, 2017.

Imagem 94 - Implantação do empreendimento PC_APTO_1.

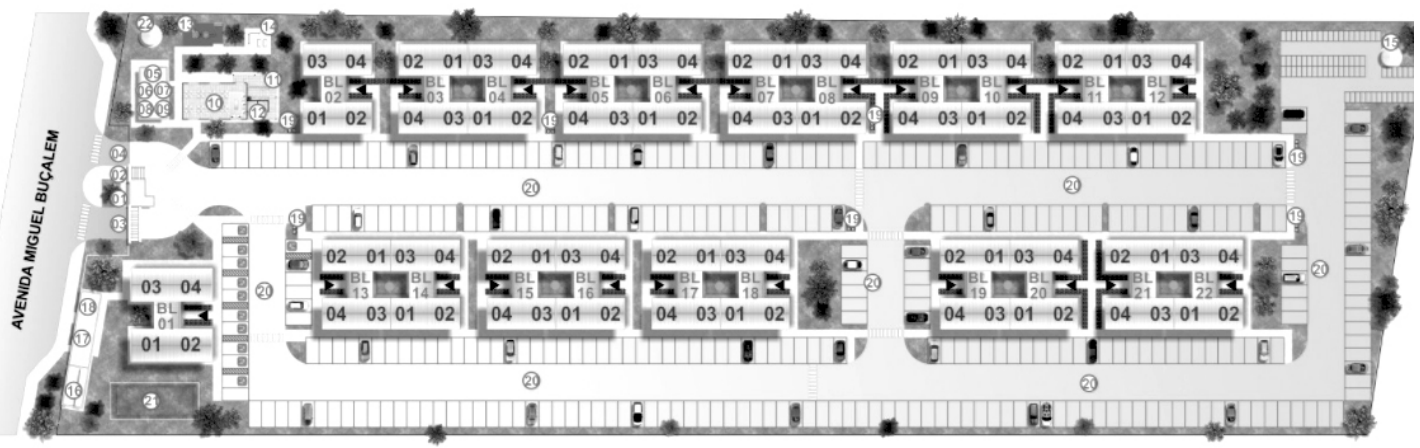

FONTE: Site da construtora, 2017. 
Imagem 95 - Planta tipo PC_APTO_1 opção 1 e 2.
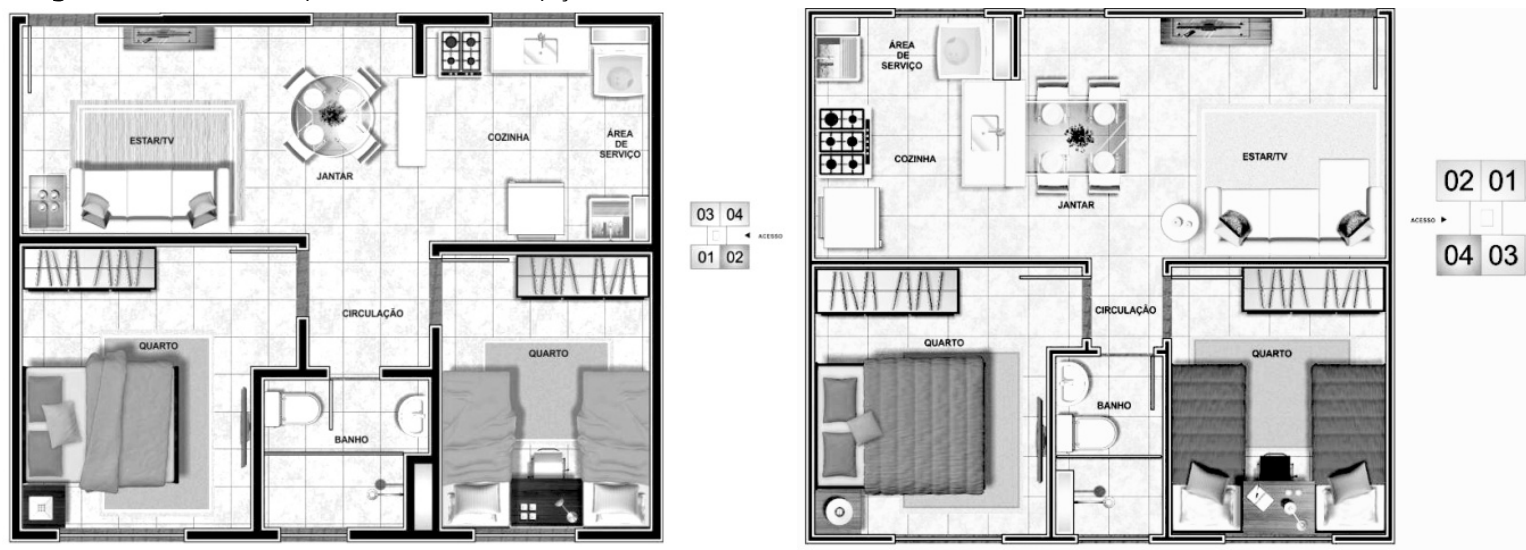

FONTE: Site da construtora, 2017.

\section{Canteiro 3-PC_APTO_2}

- LOCALIZAÇ̃̃o: São Carlos/SP

- SISTEMA CONSTRUTIVO: Paredes de concreto

- TIPOLOGIA: Apartamentos de $41 \mathrm{~m}^{2}$ a $47 \mathrm{~m}^{2}$

- IMPLANTAÇÃO: 32 blocos de 4 pavimentos e 1 bloco PNE de 5 pavimentos

- NÚMERO DE UNIDADES: 532 apartamentos

Imagem 96 - Inserção urbana do empreendimento PC_APTO_2.

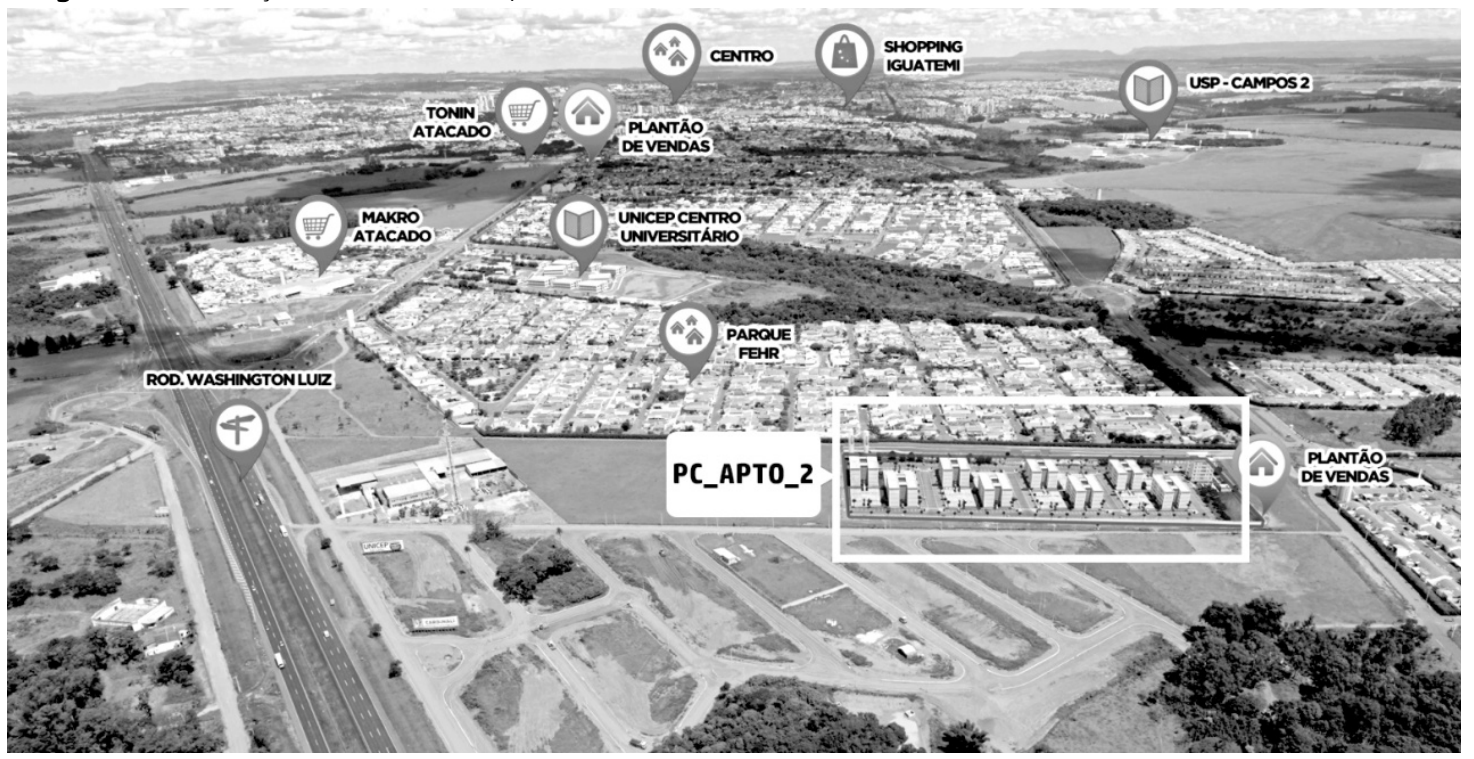

FONTE: Elaboração própria a partir de imagem divulgada pela construtora, 2017. 
Imagem 97 - Implantação do empreendimento PC_APTO_2.

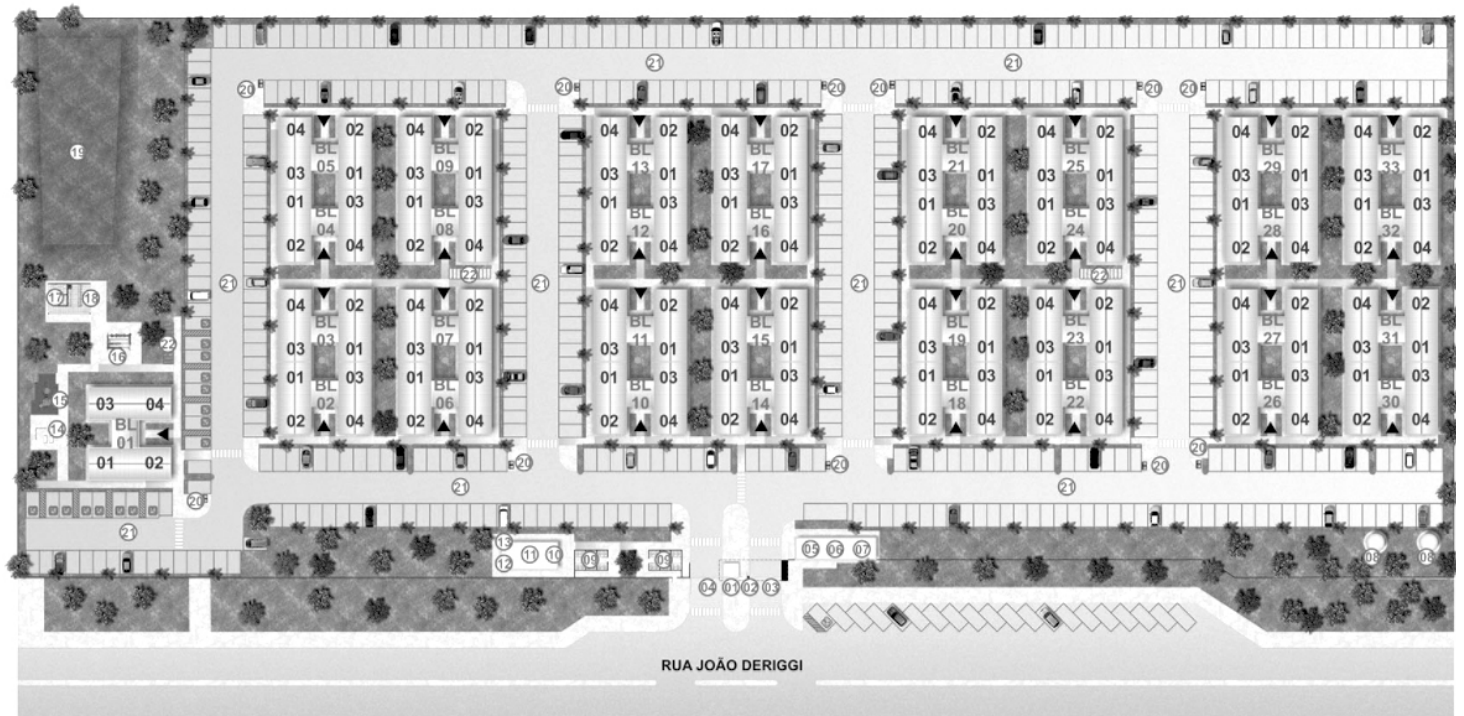

FONTE: Site da construtora, 2017.

Imagem 98 - Planta tipo PC_APTO_2 opção 1 e 2.
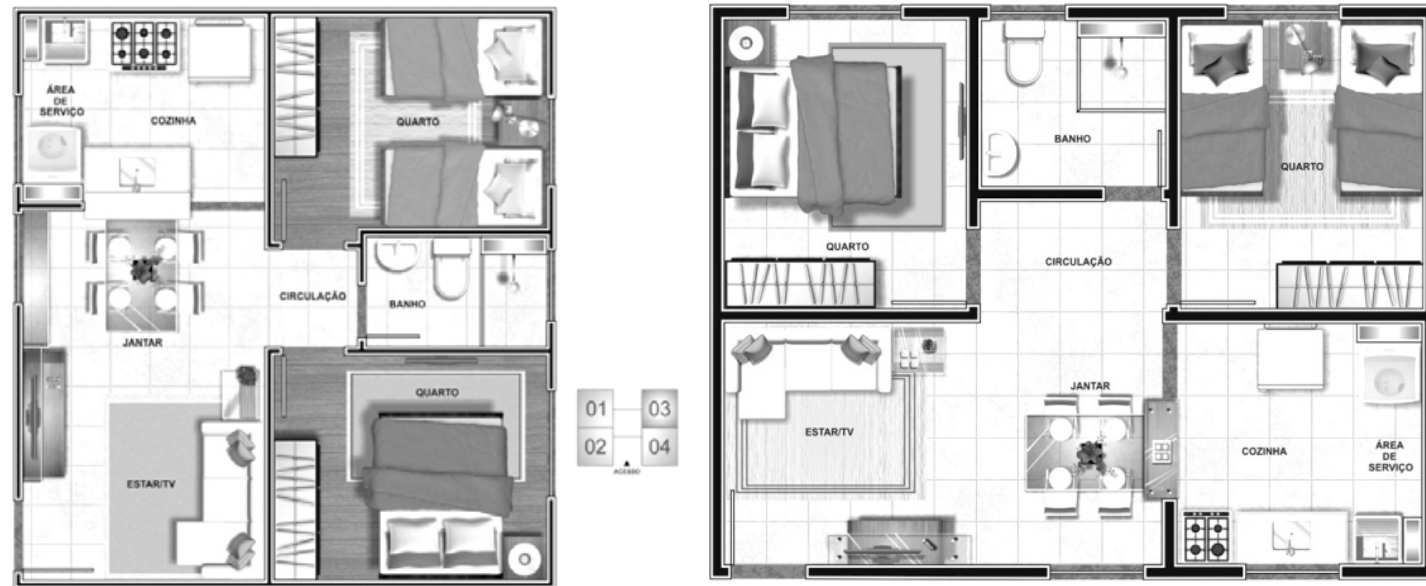

FONTE: Site da construtora, 2017.

Canteiro 4-PC_CASA_1

- LOCALIZAÇÃO: São Carlos/SP

- SISTEMA CONSTRUTIVO: Paredes de concreto

- TIPOLOGIA: Casas térreas de $36 \mathrm{~m}^{2}$

- TERRENO: $160 \mathrm{~m}^{2}$

- NÚMERO DE UNIDADES: 986 casas 
Imagem 99 - Inserção urbana do empreendimento PC_CASA_1.

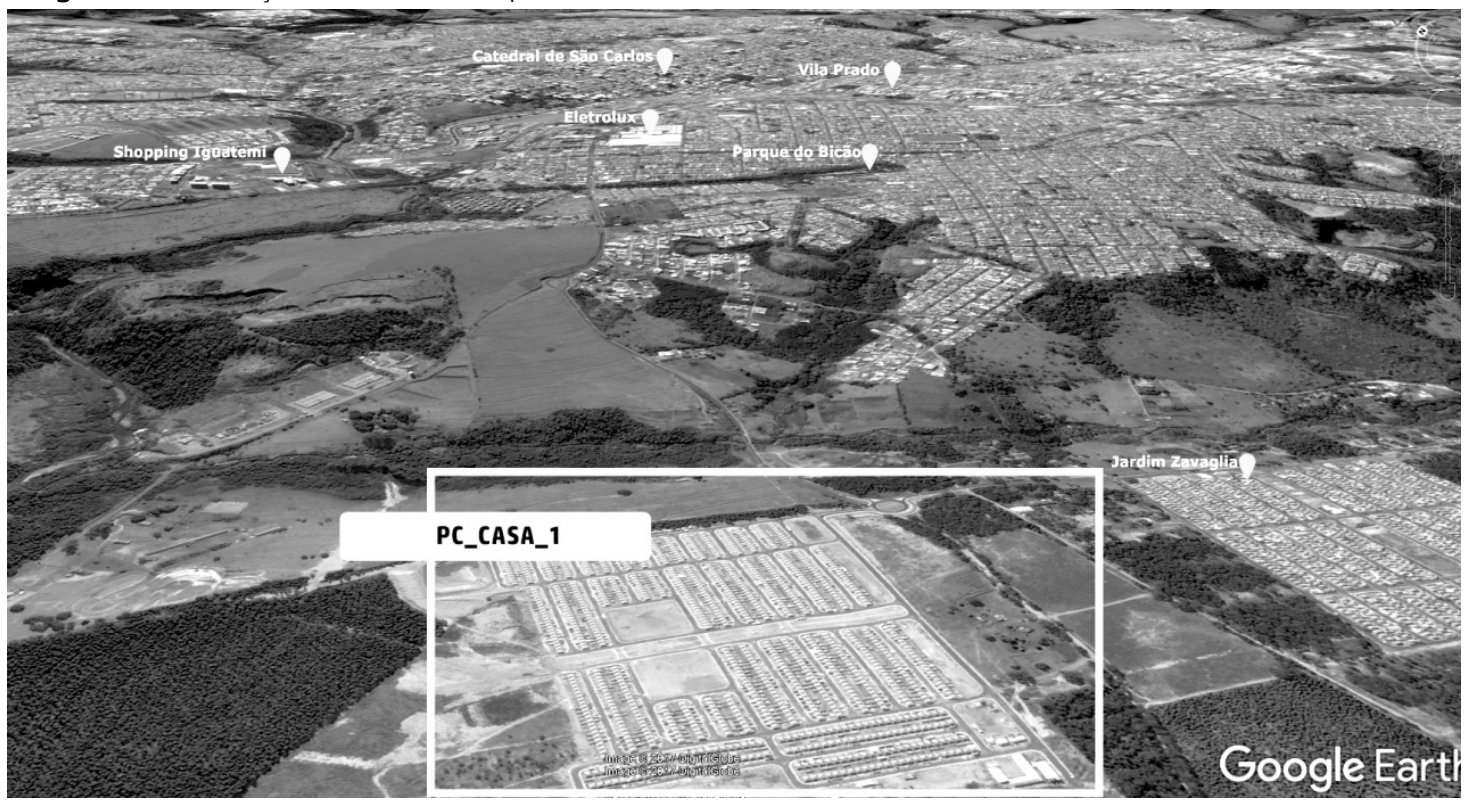

FONTE: Elaboração própria a partir de imagem do Google Earth, 2017.

Imagem 100 - Implantação do empreendimento PC_CASA_1.

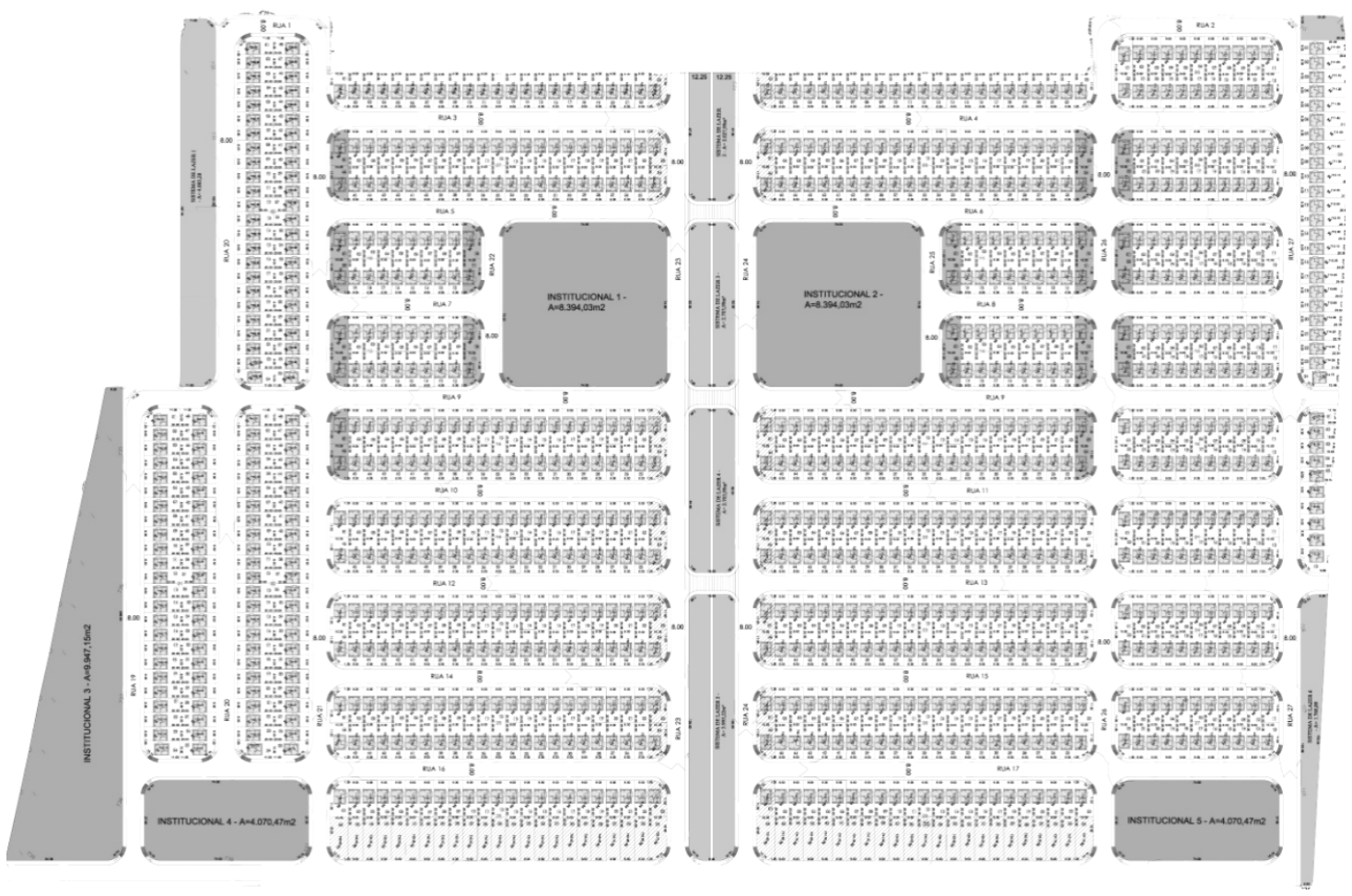

FONTE: Disponibilizada pela construtora, 2015. 
Imagem 101 - Planta tipo e perspectiva PC_CASA_1.

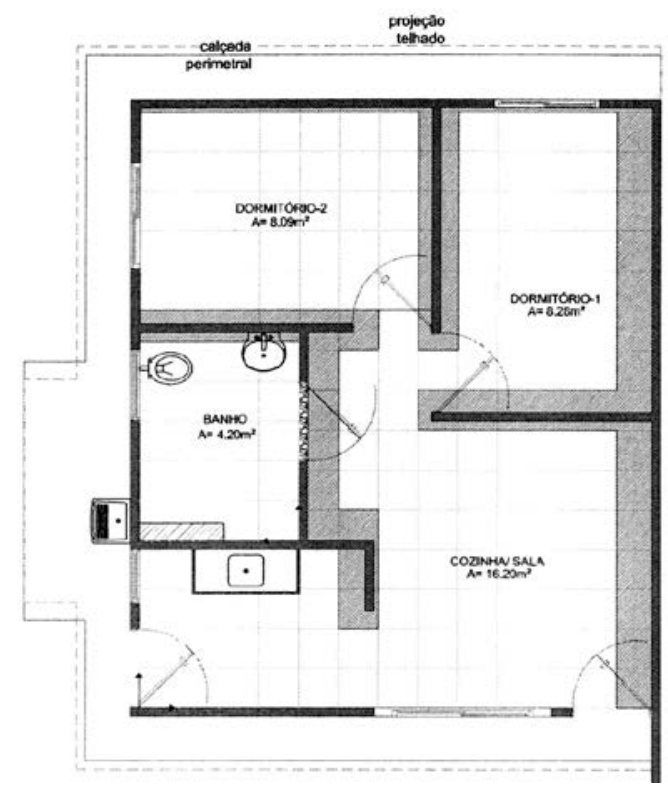

FONTE: Disponibilizada pela construtora, 2015.

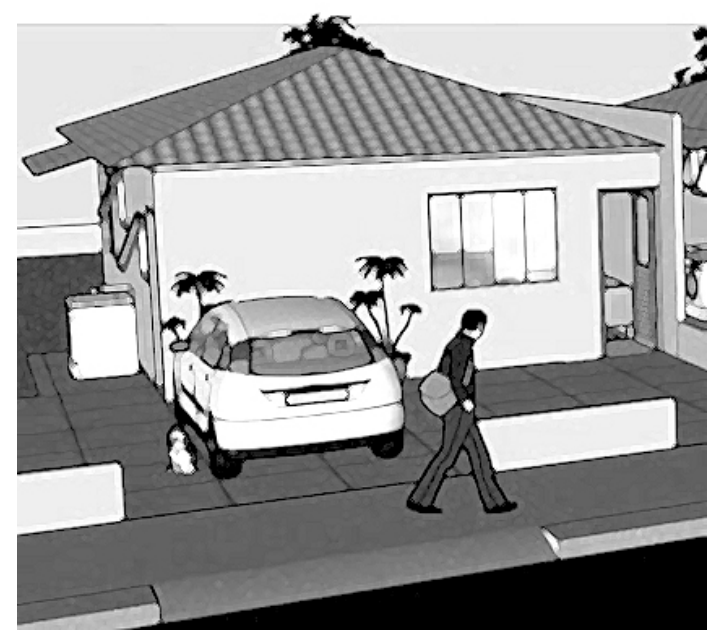

FONTE: Site da construtora, 2015.

\section{Canteiro 5-PC_CASA_2}

- LOCALIZAÇÃO: Araraquara/SP

- SISTEMA CONSTRUTIVO: Paredes de concreto

- TIPOLOGIA: Casas térreas de $44 \mathrm{~m}^{2}$

- TERRENO: $200 \mathrm{~m}^{2}$

- NÚMERO DE UNIDADES: 618 casas

Imagem 102 - Inserção urbana do empreendimento PC_CASA_2.

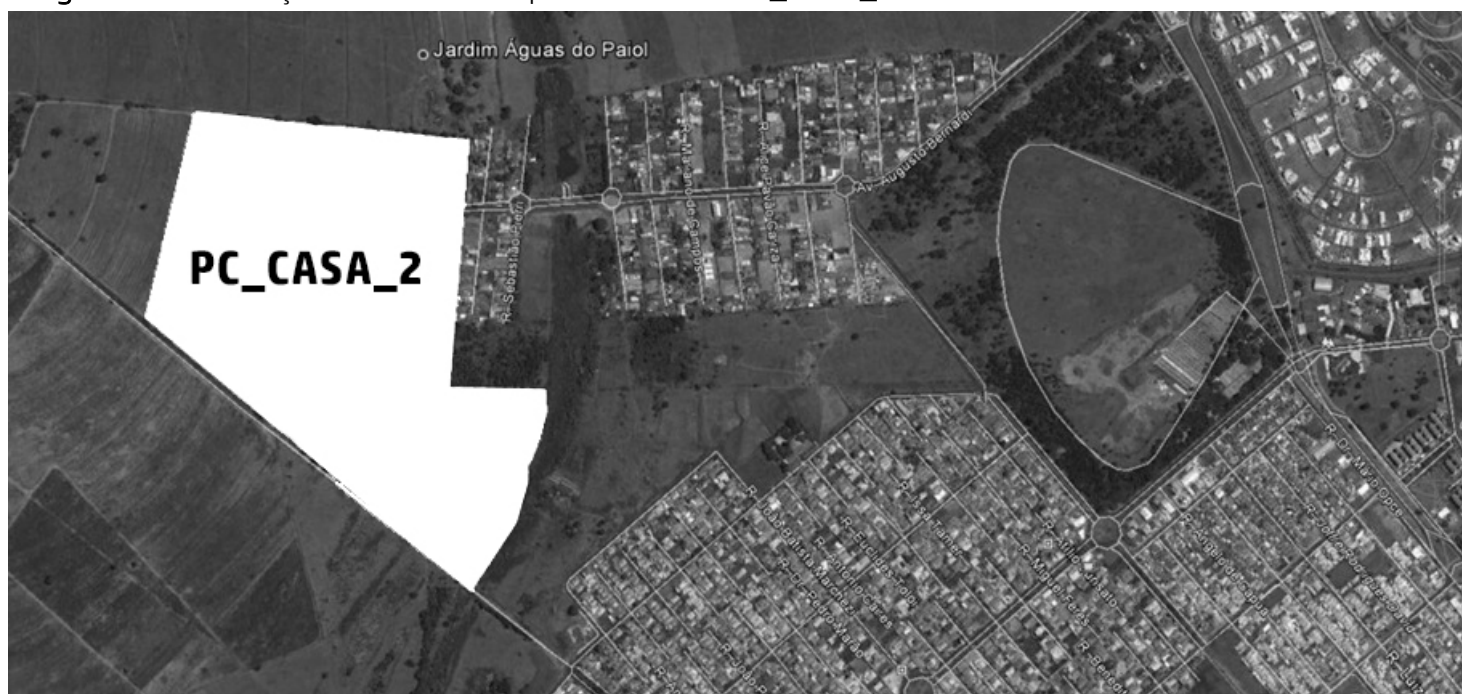

FONTE: Site da construtora, 2016, 
Imagem 103 - Esquema de implantação do empreendimento PC_CASA_2.

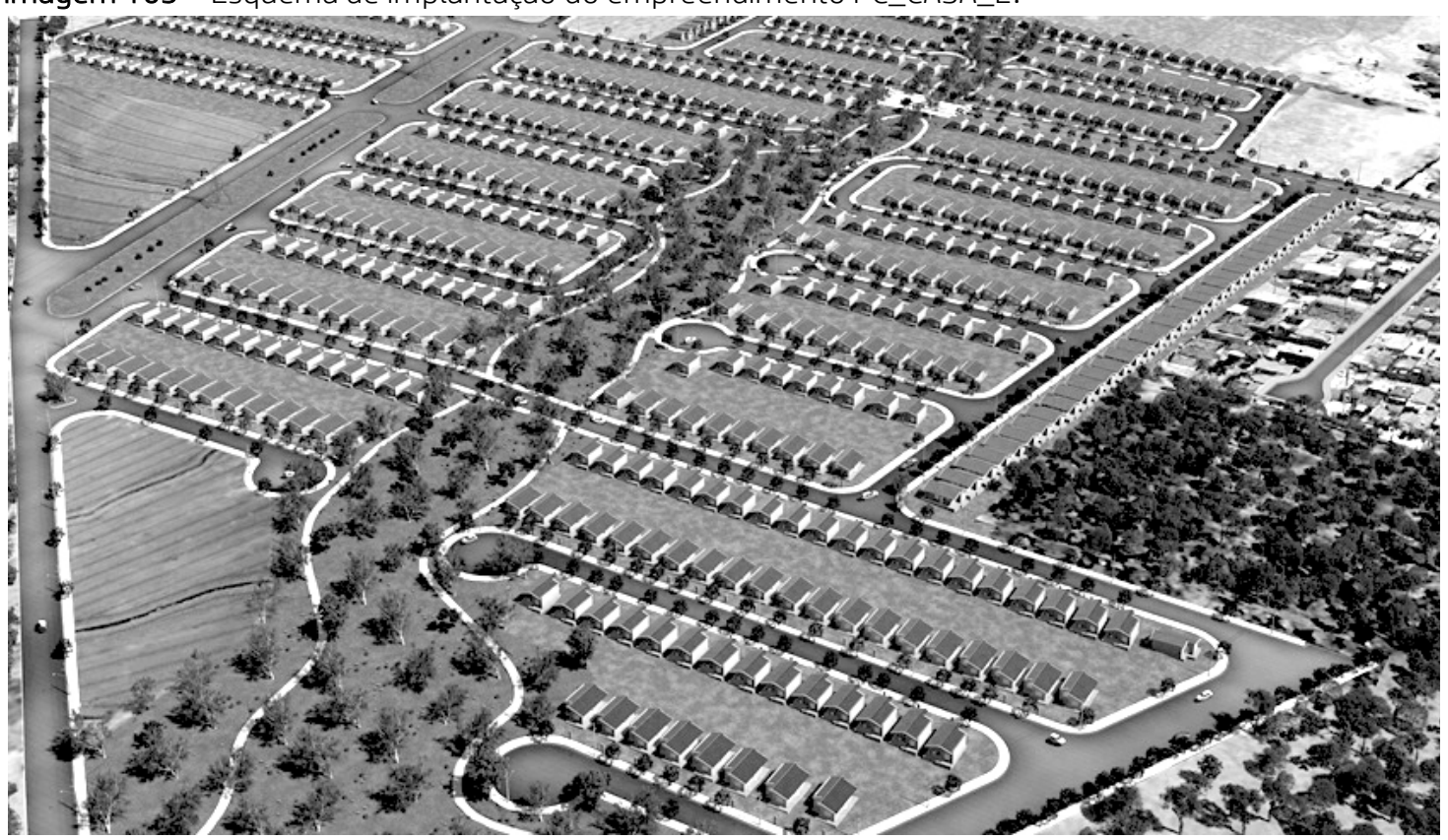

FONTE: Site da construtora, 2016.

Imagem 104 - Perspectiva PC_CASA_2.

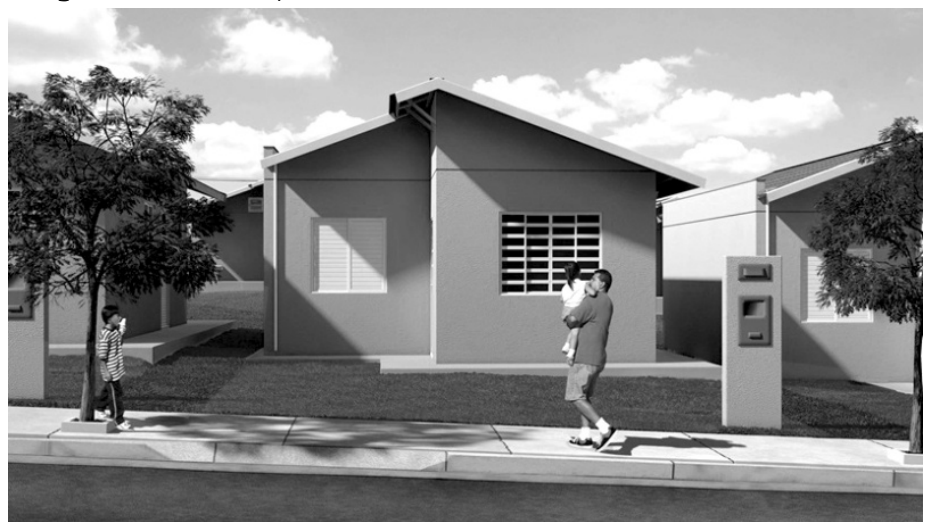

FONTE: Site da construtora, 2016. 
ANEXO 2

Organogramas das empresas construtoras pesquisadas 
Imagem 105 - Organograma da Empresa Nacional.
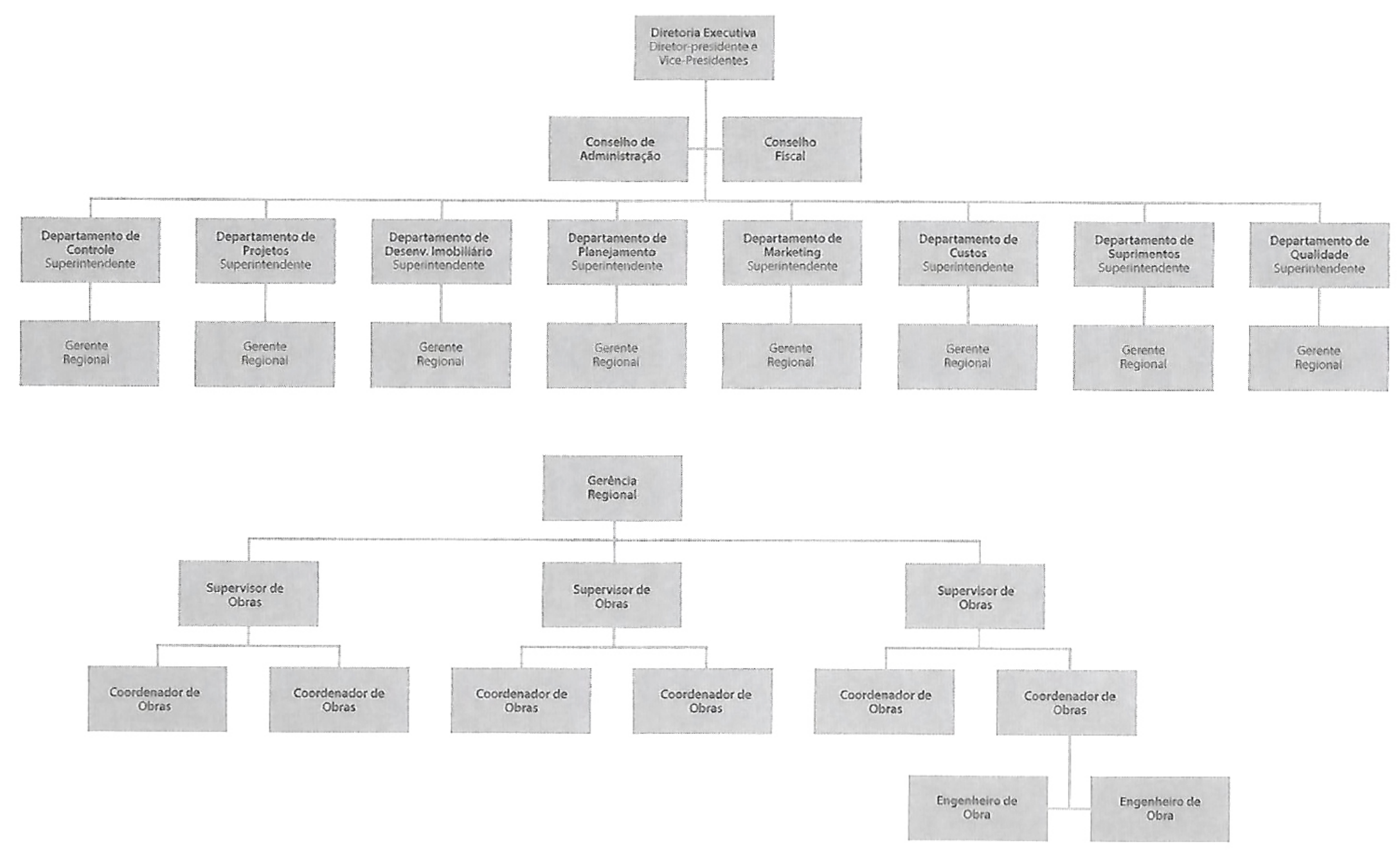

FONTE: Shimbo, 2012, p.95. 
Imagem 106 - Organograma da Empresa Regional.

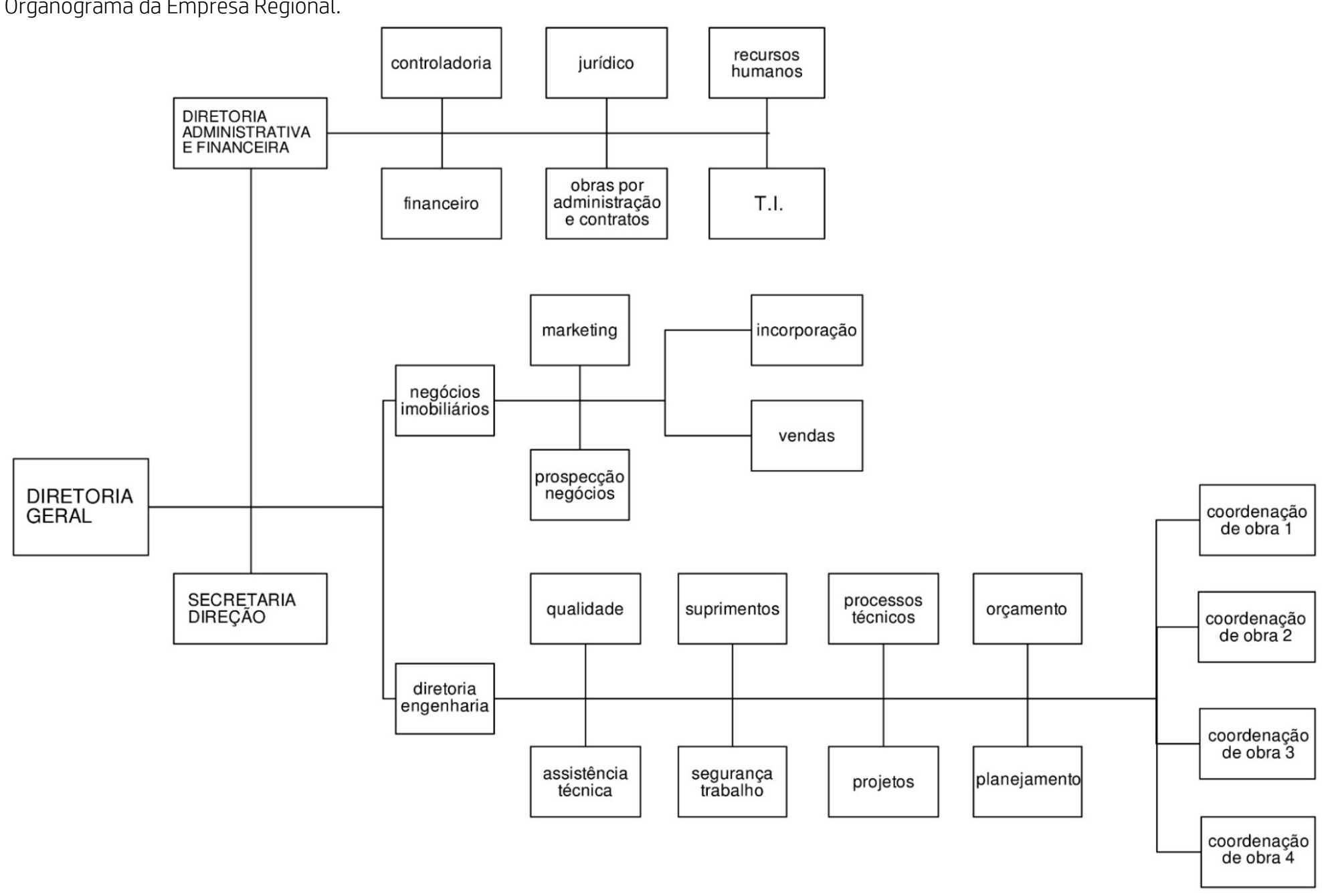

FONTE: Elaboraç̃a própria, jan/2018. 